\title{
日本醫科 大學雜誌
}

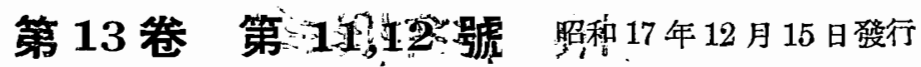

\section{術後空腸潰瘍》戚因 斵スル實驗的 病理組織學的研究}

影立神戶病院病理科研究堂(指導 中院孝圓博士)

縣立神戸病院 外科(主任 藤田 登博士)

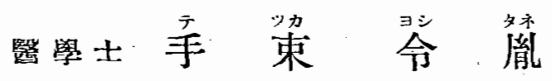

(昭和 16 年 12 月 25 日受理)

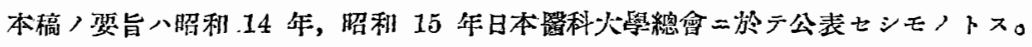

\begin{tabular}{|c|c|}
\hline 目 & 次 \\
\hline 第1章 緒 言 & 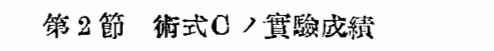 \\
\hline 第 2 音 賽䭻方法概括 & 第 3 節 術式D/賽劇成綪 \\
\hline 第 1 節 實驗材料 & 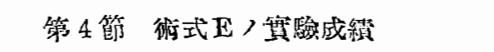 \\
\hline 第2笻 昽前處置 & 第 5 節 術式第 2 群/賽驗成線小括 \\
\hline 第 3 節 一般衍式 & 第 1 項 一般狀態及ビ剖檢所見 \\
\hline 第 4 節 随後處置 & 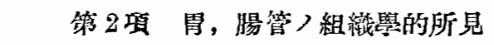 \\
\hline 第 5 節 屁體解剖亚二組織學的檢查 & 第与章 惦式第 3 群 \\
\hline 第 3 章 術式第 1 群 & 第 1 節 術式 E.)實駿成績 \\
\hline 第 1 節 手術式(術式A) & 第 2 節 迁式G/實路成績 \\
\hline 第 2 節 實匳成績 & 第 3 節 術式 $\mathrm{H}$ >實驗成績 \\
\hline 第 3 節 術式第 1 群/賽驗成績小括 & 第 4 節 琎式 I / 實驗成績 \\
\hline 第 1 項 猃後一般狀態. & 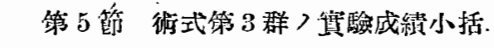 \\
\hline 第 2 項 火便ノ跣狀 & 第1項一般狀熊及ビ剖檢所見 \\
\hline 第 3 項 腹腔內所見 & 筇 2 項 胃, 腸管ノ組織學的所見. \\
\hline 第 4 項 溃 瘍 & 第 6 章 術式第 4 群 \\
\hline 第 5 項 糜 爛 & 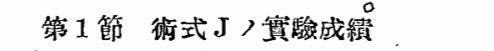 \\
\hline 第6 項 淋巴滤胞 & 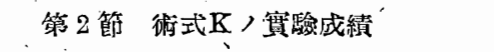 \\
\hline 第 7 項 胃, 空腸, 十二指腸粘膜，組織學的 & 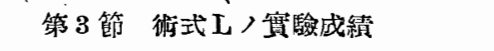 \\
\hline 一所見 & 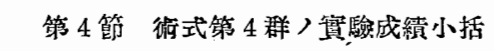 \\
\hline 第 8 項 胃度ビ腸管壁，組織學的所見 & 第 7 章 術式第 5 群 \\
\hline 第 4 章 術式第 2 群 & 第 1 節 實驗战績 \\
\hline 第 1 節 術式B /實驗成績 & 第 2節 小 括 \\
\hline
\end{tabular}


第 8 学 琎式第 6 群

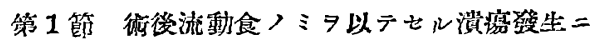
就テ

䈨 2 節 小 括
第 9 章 總 括

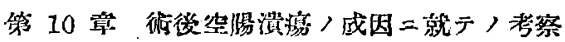

第 11 章 結 論

\section{第 1 章 緒 言}

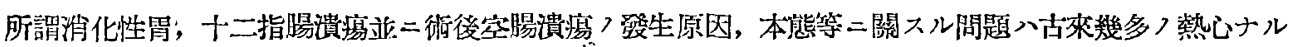
研究ガ繰り返サレタルニ狗ラズ, 今日ニ至ルモ尚未解決／狀態ニアル極メテ困難ナル問題ナリ，而カモ内 科的或ハ外科的臨侏上電要ナルモフナリ。

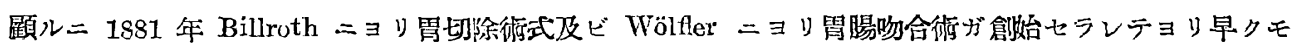

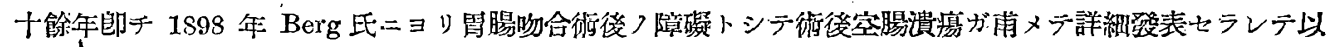

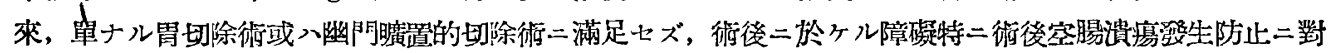

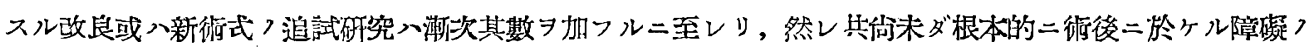

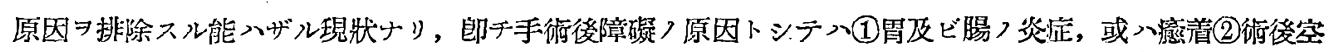

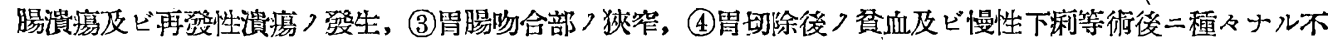
虑?障礙习偶發スルコトアル入吾人ノ經驗スルトコロナリ。

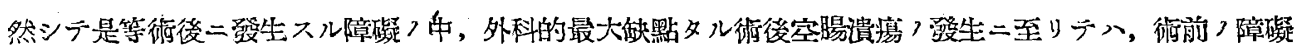
二比シ倍加サルルモフニシテ, 又極メテ高率二發生セル入周知? 事實ナリ, 而シテソフ防止策トシテ今日

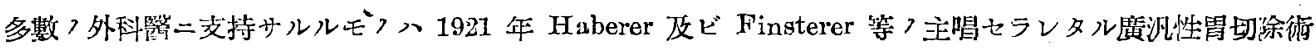

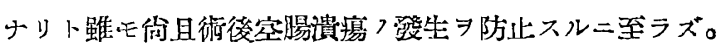

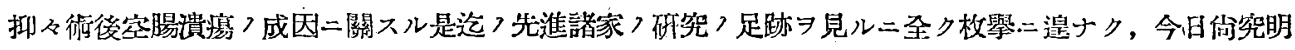
スルニ至ラズ, 今其主ナルモフ 列擧スレバ

1), 錯于二シコル障礙梳。

2), 不吸收性綘合絲 7 障砣喰,

3), 食踙 $=ヨ$ ル機栰的障礙說,

4), 胃液二ヨル生化學的作用說,

5), 神經障䃎說,

6), 炎衝說,

7), 部分的榮養障礙梳,

8), 淋巴潈胞說,

9), 細菌說,

10), 空腸粘膜ガ盟夜二慣從セザル非生理的關係,

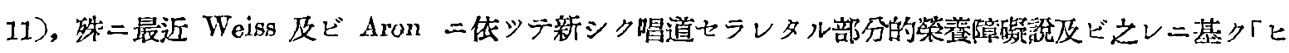
スチデン」潦法, 等

實二種々新多?學說ガ反複主張セラレ諴二混沌タル狀態ナリ。

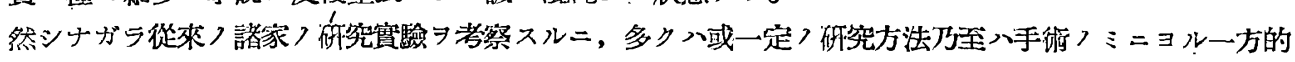

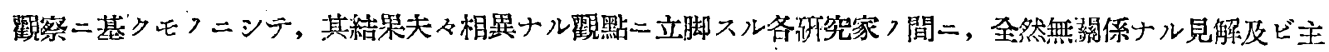

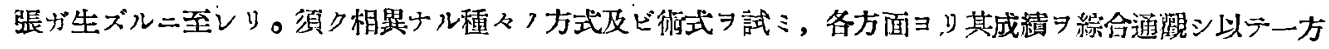

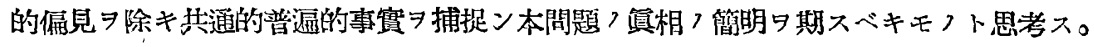

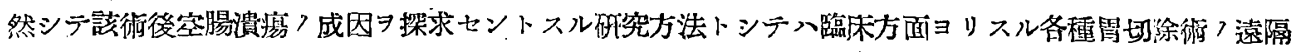

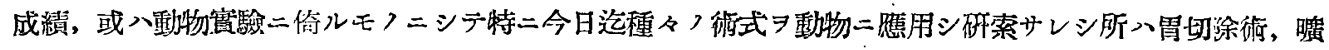
置的胃切除術, 胃腸吻合術或入十二指腸內容䡜向術ナリ, 而シテ此最後ニ犀スルモノニ, 1923 年 Mann

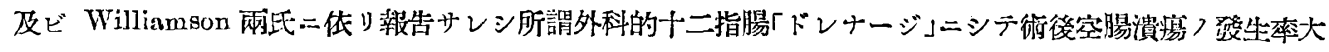




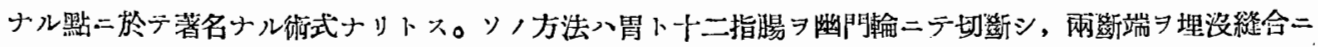
$\exists$ リ閉鎖シタル後, 更二十二指腸直下空腸〉上部二デ切斷シ,ソノ口側入迥腸下端二端側吻合ヨナシ, 目

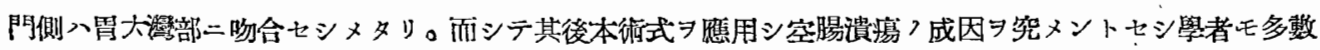
アリ殊 $=1933$ 年 Weiss 及ビ Aron 兩氏八前述ノ外科的十二指腸「ドレナージ」ヨ犬二隹用シ, 術後 10-28 日

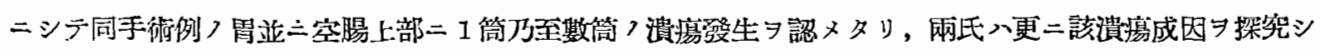
タル結果, 十二指腸液习轉流セシムべキ部位ガ迥腸上部二移行スル二從七潰瘍フ發生入遲延スル事實, 叉

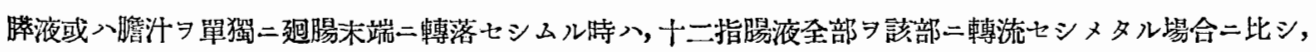

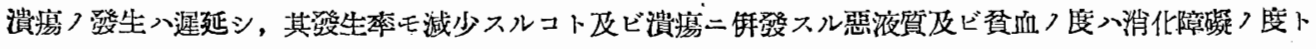
み゙行スルコトヨリシテ, 斯ル溃瘍つ成因ヨ術後腸管內二於ヶル蛋白質ノ消化障礙ニヨル晹壁抵抗力フ減弱 二歸納セり。

然シテ余モ亦 Mann 及ビ Williamson 兩氏ノ外科的十二指腸「ドレナージ」ヨ先ヅ豫備的實驗トシテ犬

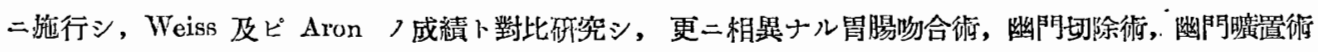

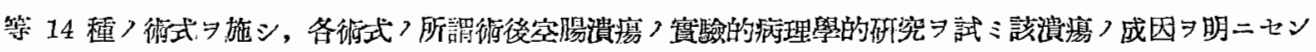

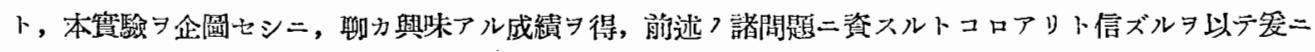
其詳細习垠告シ，脌セテ諸家ノ御批制

\section{第 2 章 實驗方法概括}

第 1 節 實 驗 材 料

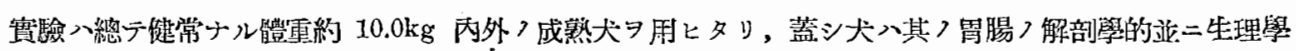

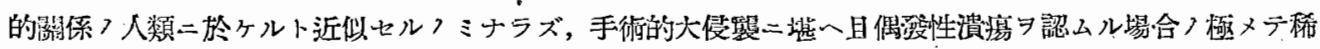

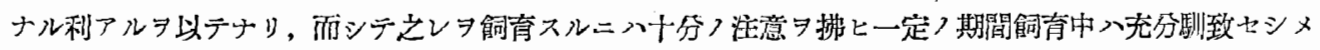
或入疾病つ發見二努入健康ナルヨ確カメ實驗ニ供シタリ。

\section{第 2 節 術 前 處 置}

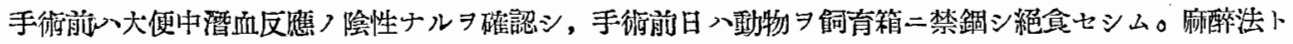

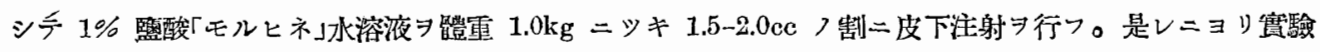

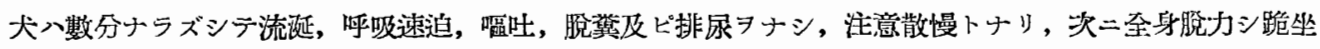

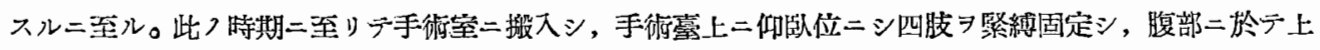

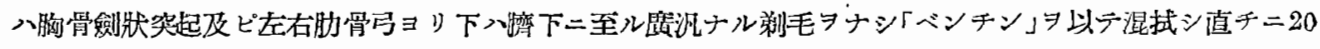

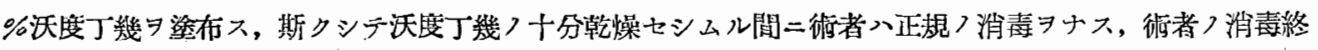

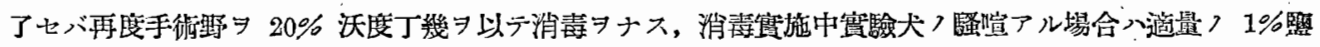
酸「モルヒネ」ヨ助手ヨシテ追加セシムルコトニヨリ手術中「エーテル」等ヨ用ヒズ終始容易二璝施シ得タ リ。

\section{第 3 節 一 般 術 式}

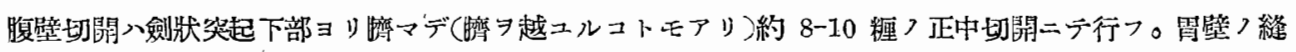

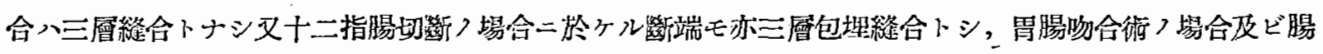

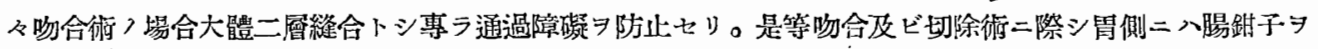
用ヒタルモ空腸侧ニ八用ヒシモフト用ヒザルモノトノ二通リタナス, 而シテ腸鋪子八一般使用セラルル Doyen 民腸錙子二改良 7 加へ彈力性 7 與一腸粘膜損傷 7 可及的輕少ナラシムルニ努メタリ。縫合絲入總

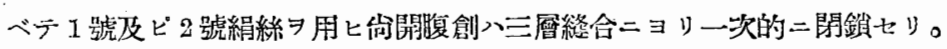

\section{第 4 節 術 後 處 置}

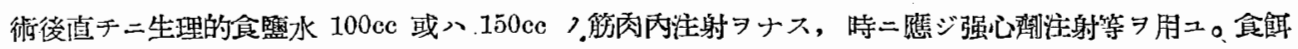

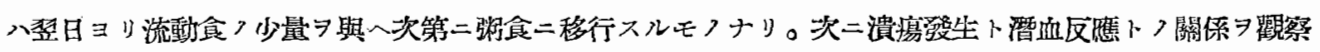

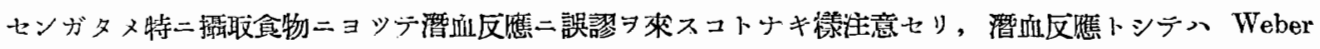




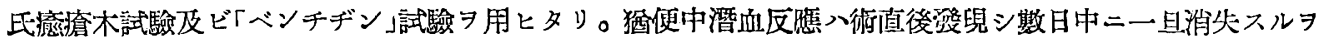

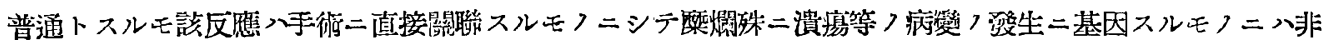

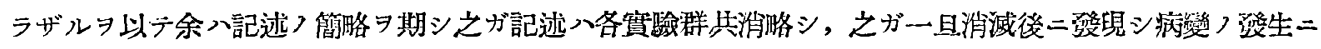

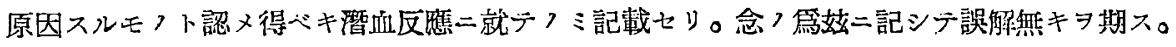

\section{第 5 節 屁體解娪並二組織淟的檢査}

尼體解剖八自然死及ビ着殺後ヨ通ジテ可及的速二剖檢ニ附スコトトセリ。而シテ啳殺方法トシテハ絞殺

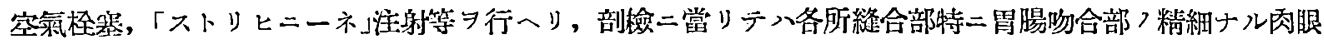

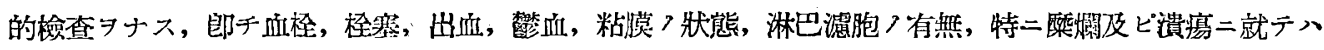
大キサ, 形狀, 周園トフ閵係, 晹間膜トフ關係等习精密二觀察セり。

組織學的檢查入主トシテ胃(貲門部，大小灣，幽門部)十二指腸(上, 下部)，胃空晹吻合部特二溃㾂入勿

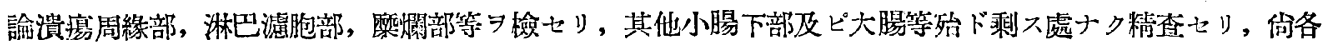

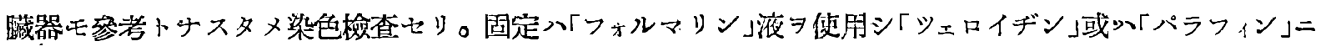
包埋シ「ヘマトキシリン、エオデン」電複染色, Van Gieson 氏染色, Weigert 彈力繊維染色法等习施シ檢 查セり。

\section{第 3 章 術式第 1 群}

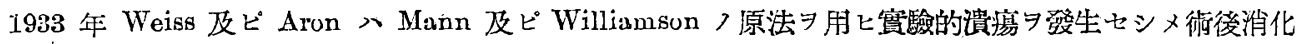

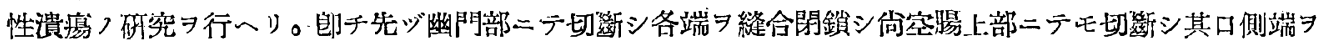
趣腸末端二吻合シ，妅門侧 $ヨ$ 胃二吻合スル所謂外科的十二指腸「ドレナージ」ヨ施行シタルニ其症例フ 100

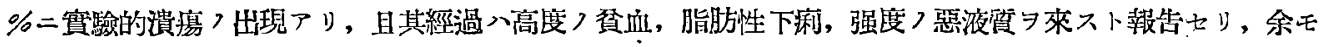

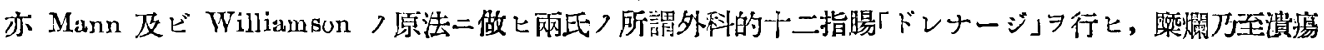
フ發生部位, 發生數, 形態, 或入其肉眼的站二組織學的所見 7 觀察シ, 是等實驗成禎卜Weiss及ピ Aron

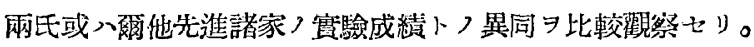

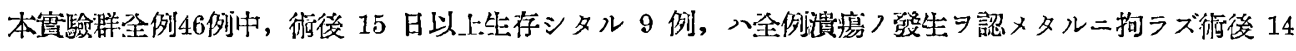

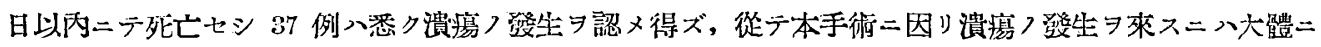

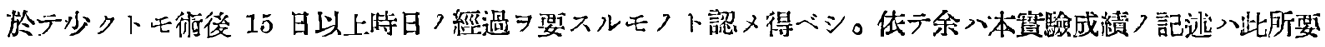
期間生存二耐工得タル 9 例二止入爾他 37 例二就テ八其大略 7 上記 9 例下共二第 1 第 2 表二表示セり。

第 1 節 手術式 (衡式 $A$ )

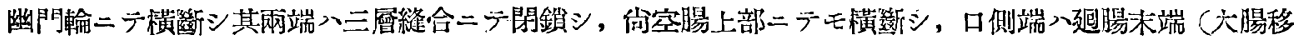

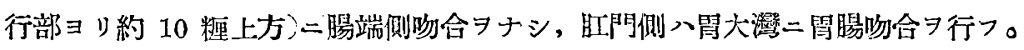

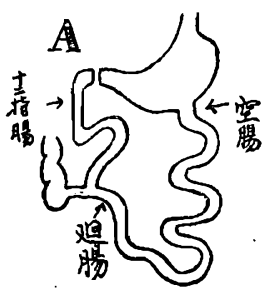
$\mathrm{Nr}, 4$, ㅇ, $14.0 \mathrm{~kg}$.

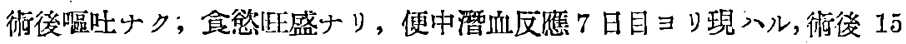

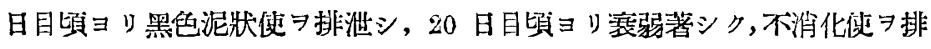
出シ終 $=30$ 日目二死亡ス。解剖學的所見, 腹腔內二多量 ᄀ膿汁アリ, 胃

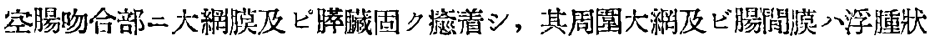

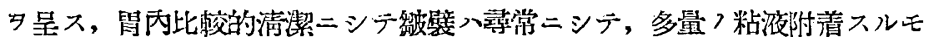

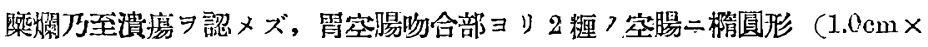

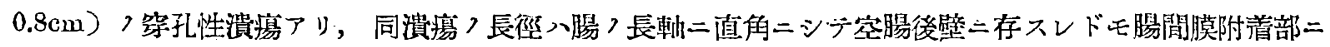

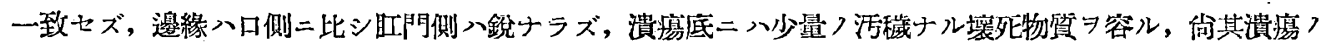

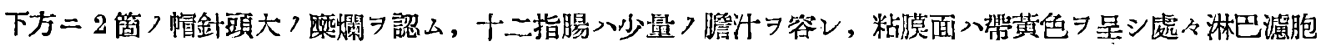
フ肥大セル 認ム, 上部空晹粘膜二於テモ濾胞〉腫脤アリ。組織學的所見, 胃粘膜固有層入其構造殆ド不 明トナリ, 結締織つ增惐アリ, 主細胞及ビ壁細胞入脫落シ殘存セルモ〉八高度つ萎縮ニ陷レルヨ認ム, 其

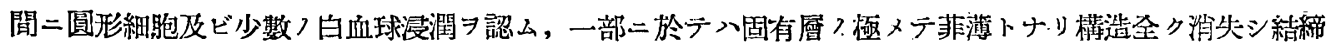




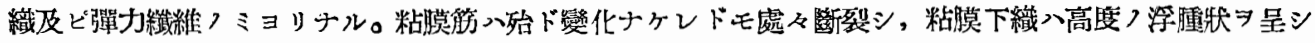

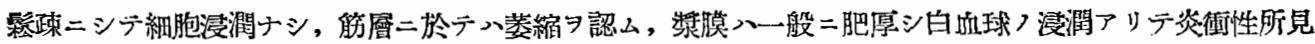

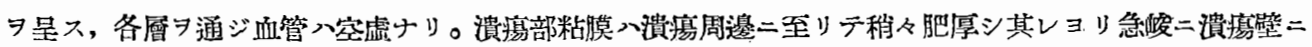

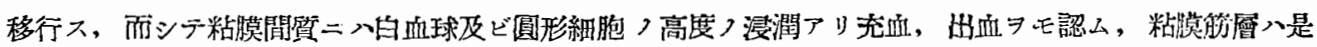

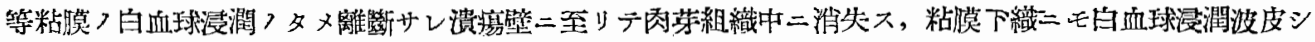

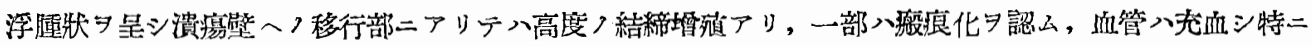

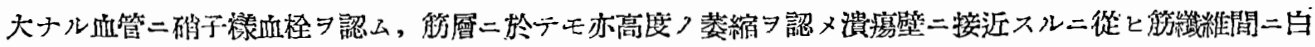

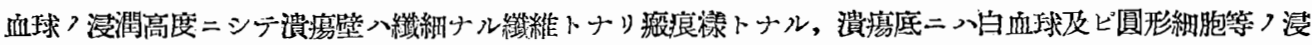

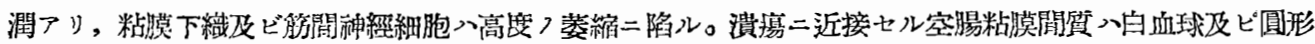

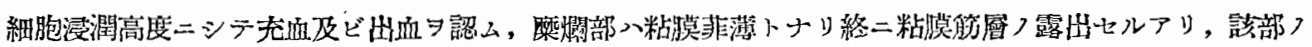
粘膜下織及ビ其附近入浮腫高度ナリ。十二指腸粘膜つ構造二於テ著變ナケレドモ，輕度つ白血球及ピ圓形 細胞つ核潤アリ，或入上皮細胞〉萎縮二陷り，或入脫落セルアリ，粘膜筋入處々斷裂アルモ粘膜つ細胞漫

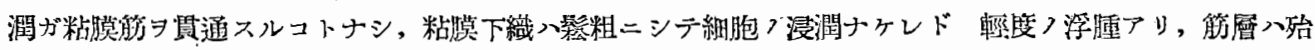

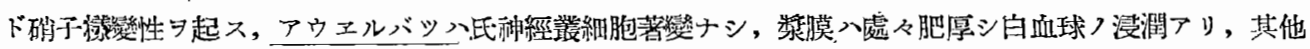
淋巴濾胞入著明二肥大シ空腸上部ニ於ヶル濾胞腫大八顥著ニシテ濾胞つ直接腸管內二露出セルタ認ム。

Nr., 14, 合, 10.0kg.,

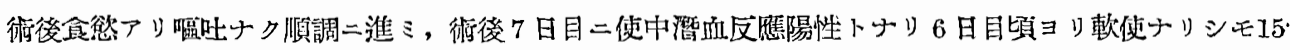

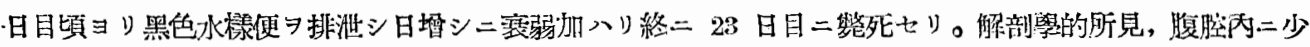

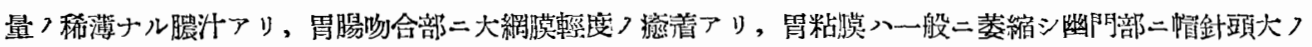

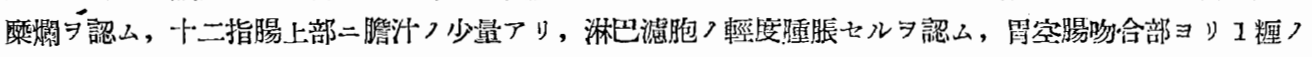

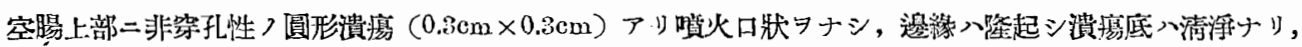

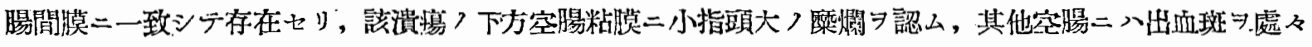

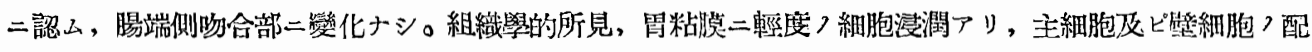
列モ正シケレドモ一般二蒌縮シ腺管入短縮シ上皮細胞つ一部入變性二陷り，幽門部二至りテ入高度〉圓形

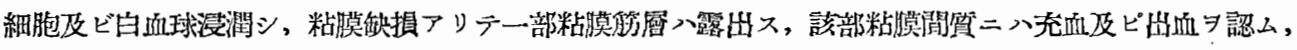

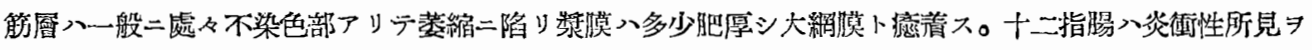

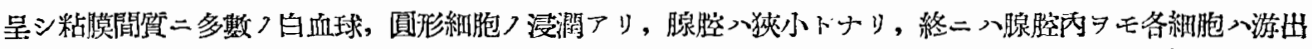

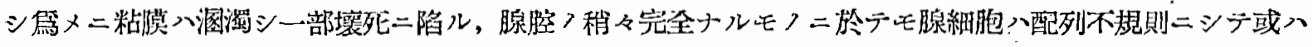

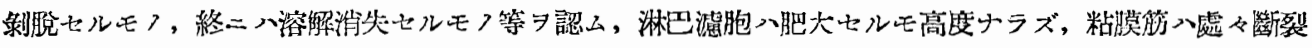

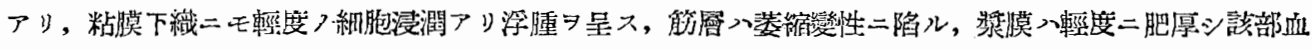

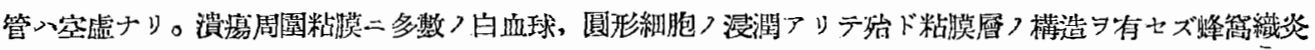

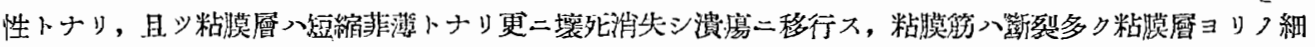

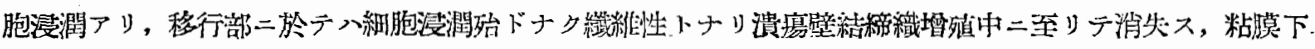

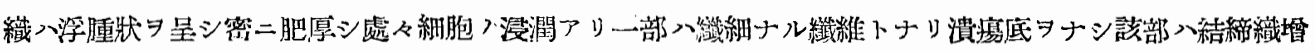

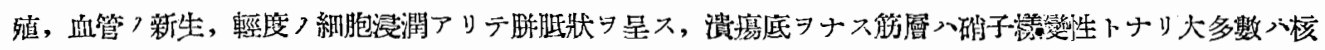

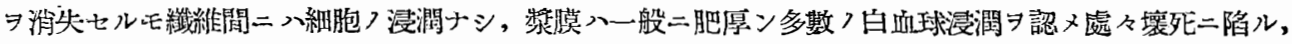

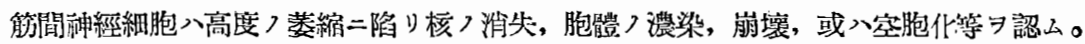

Nr., 20, 우, 11.0kg.,

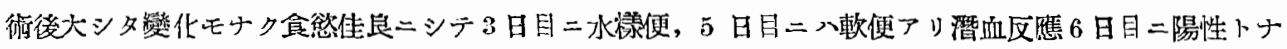

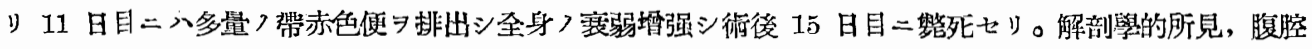

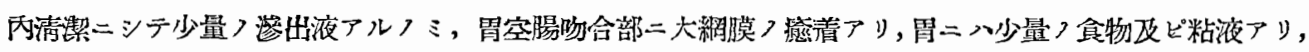

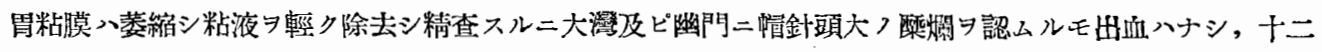




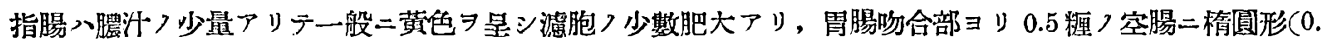

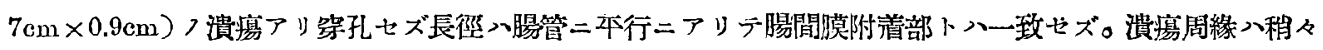

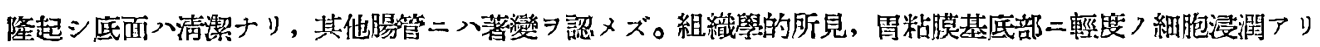
高度〉充血习認么, 主細胞及ビ壁細胞つ配列不規則:シテ核ハピクフ一ゼ或入原形貿つ溶解及ビ消失アリ テ初期壞死二陷ル，殘レル壁細胞ノ原形畝入「ヘマトキシリン」色习帶ピテ赤紫色二着色ス，一部粘膜入剥

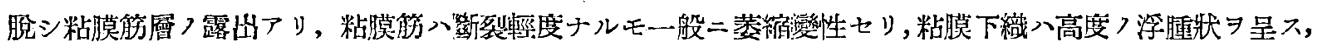

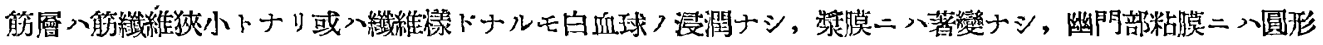

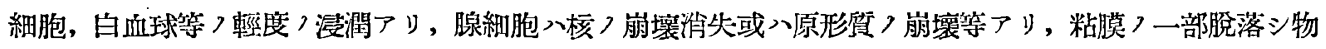

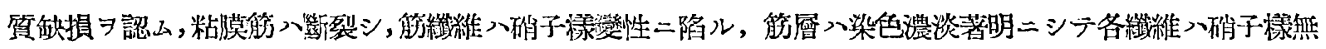

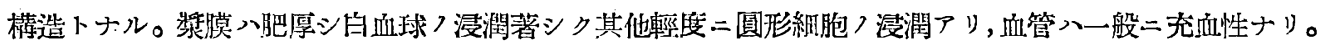

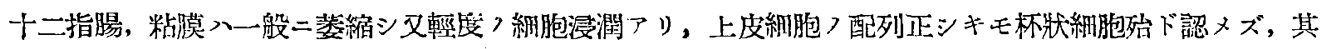

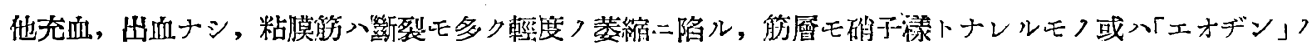

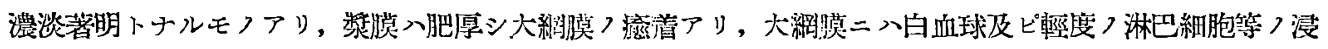

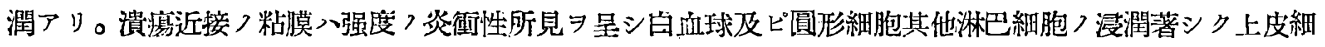

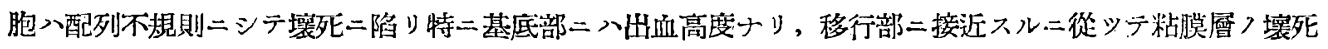

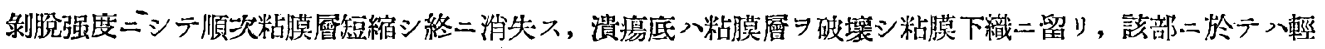

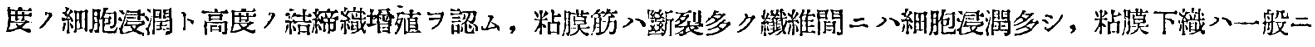

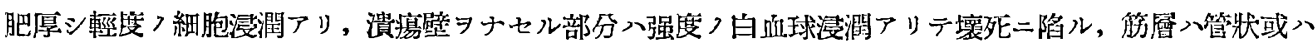

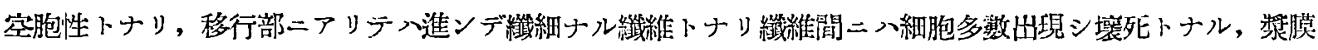
八著シク肥厚シ外側入壤死二陷ル。(第 7 圖)

Nr., 29, 우, $10.6 \mathrm{~kg} .$,

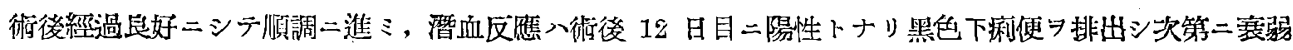

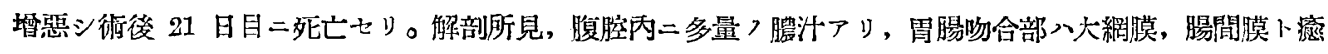

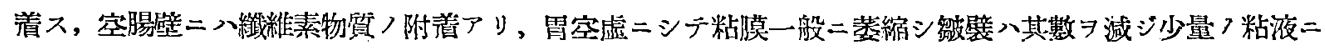

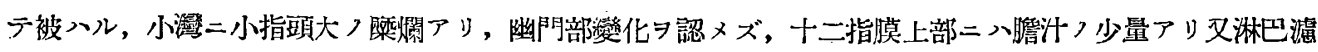

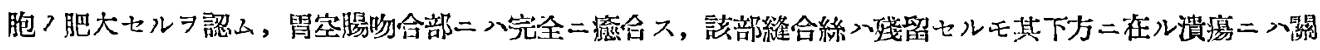

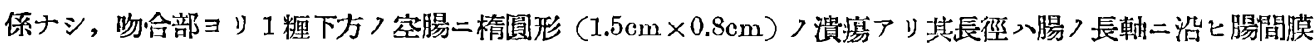

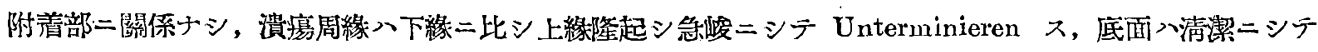
䀴門側ニ小サク毞孔ス，潰瘍近傍二小指頭大ノ「エロデオン」1筒ヨ認ム，十二指腸及ビ空腸二濾胞肥大著 明ニアリ特二空腸上部二高度ナリ。組織學的所見, 胃粘膜二於テ八腺細胞及ピ上皮細胞八一般二配列正シ

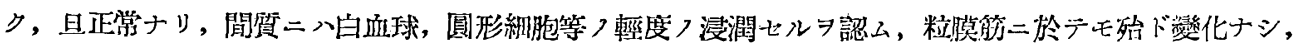

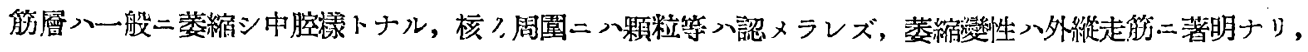

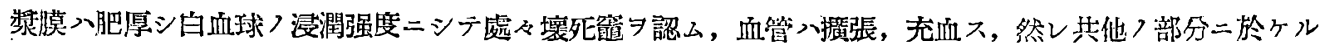

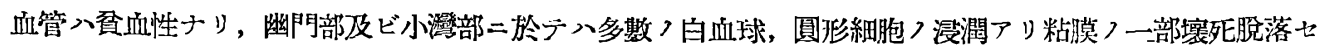

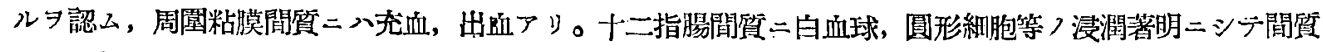
八是等細胞ニヨリ占居セラレ，腺膑入陝小トナル，然シュ上皮細胞，腺細胞入配列モ正シク未が細胞ノ溶解

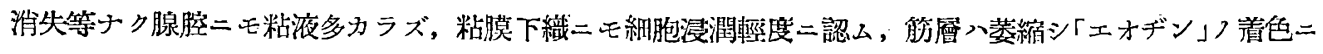

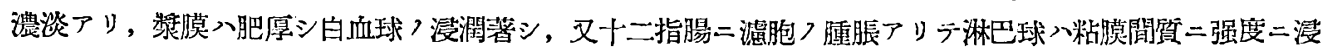
潤シ，腺細胞，上皮細胞入崩壤シ，腸管內二多稘つ淋巴球游出ス，腺管つ未が崩壤セラレザルモつ八腫脹

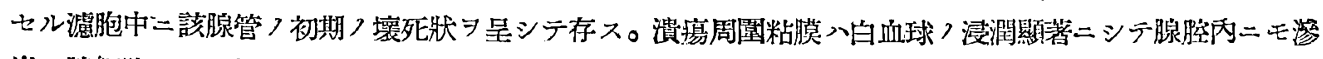

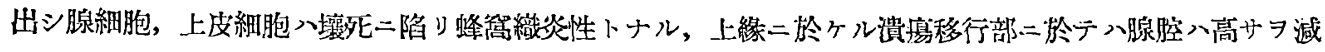

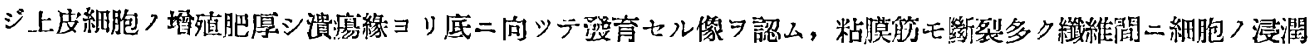


著シク粘膜下織八密二肥厚シ, 潰瘍移行部二於デ細胞浸潤著明トナル, 他方結締織, 增殖, 血管つ新生

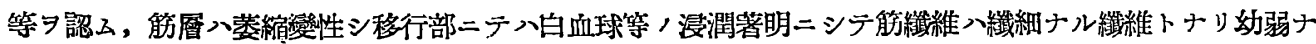

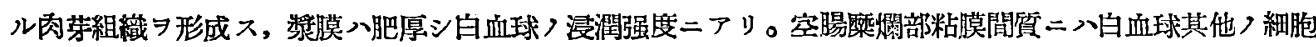
浸潤强度ニシテ小彎部ニ比シ特二充血, 出血著明ナリ，而シデ該部粘膜下織八綳胞浸潤ナヶレドモ高度， 浮腫狀ヨ呈ス。其他浿瘍ヨリ比較的遠ク距リタル空腸粘膜ニモ白血球ノ浸潤高度ニシテ基底部腺管入菱縮 シ腺細胞內二八顆粒，出現顯著ニシテー部入腺腔二脫落シ或入溶解消失セル像ヨ認ム。

Nr., 33, 우, $10.4 \mathrm{~kg}$.

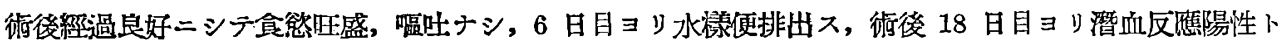

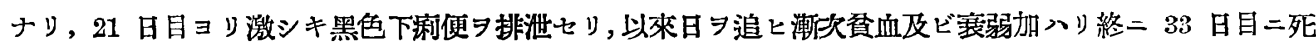

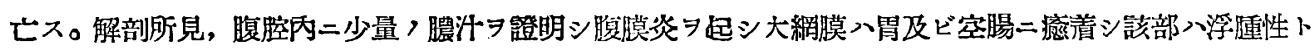

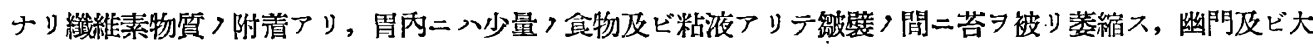

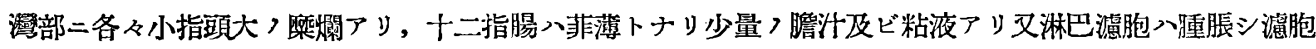

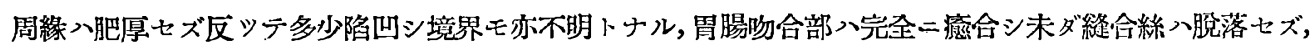

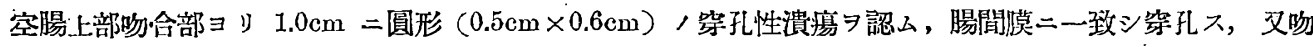
合部 $ヨ$ リ $1.5 \mathrm{~cm}$ 二圓形 $(0.3 \mathrm{~cm} \times 0.3 \mathrm{~cm})$ ，潰瘍アリ腸間膜二無關係ニシテ腸，長䩜二沿七發來セり。省 空腸壁入一般二浮腫性二肥厚シ潰瘍二接近シテ帽針頭大，出血斑习處々二認メ滤胞モ高度二腫脹セリ，腸 端側吻合部及ビ迥腸等二八著變ヨ認メズ。組織學的所見，胃粘膜二於テハ上皮細胞及ビ腺細胞，配列正シ ク間質二於ヶル細胞浸潤入殆ド認メザルモ一般二萎縮シ主細胞及ビ壁細胞つ原形質二顆粒出現シ或八之等 ガ網狀二認メラルルモノアリ, 基底部血管入充血强シ, 筋層二於テモ著變入認メラレザルモ墏膜入著シク

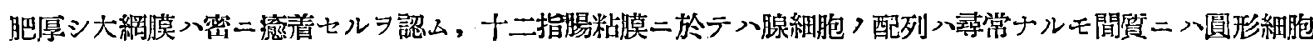
及ビ僅少ナルモ白血球ノ漫潤アリ處々上皮細胞ノ剥脫アリ又高度ノ充血及ビ出血り認ム, 粘脱筋入處々斷

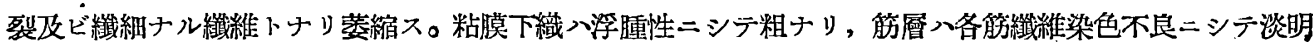

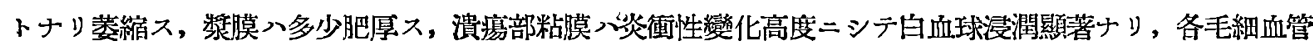

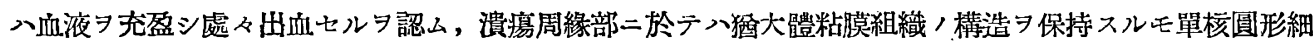
胞二代ル二高度ナル白血球浸潤アリテ一般二組織入不透明トナリ壤死二陷ル, 移行部二於デ八自血球漫潤

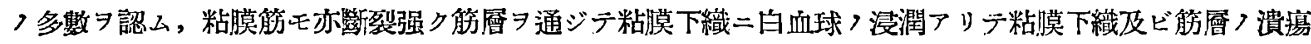

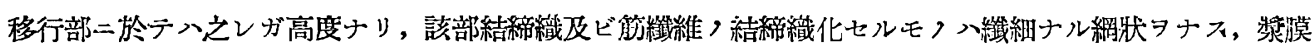

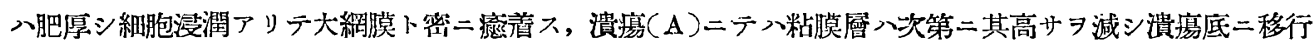

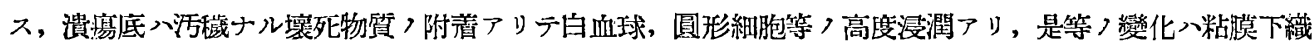

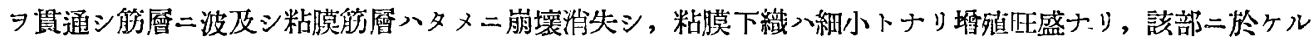

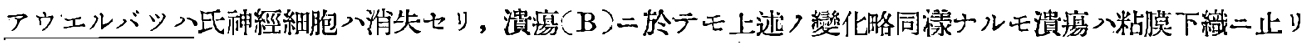

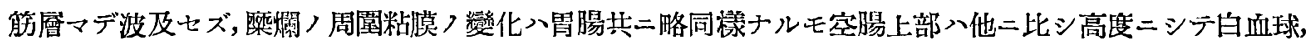
圆形細胞等ノ浸潤高度ニシテ出血及ビ充血アリ，何レモ粘莫筋ノ露出习認ム，一般二該部ノ粘膜下織入高 度, 浮腫狀 $习$ 呈ス, 其他十二指腸及ビ空腸上部, 濾胞入高度二腫脹シ一部上皮細胞 落セルタ認ム。(第 8 圖)

Nr., 34, $\hat{0}, 11.6 \mathrm{~kg}$.

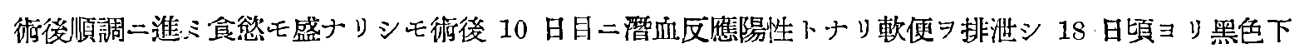

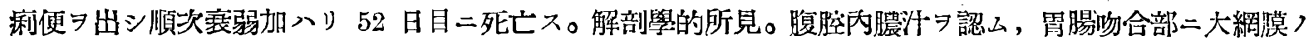

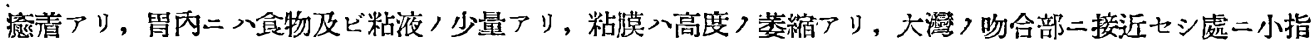

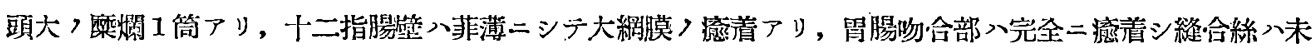

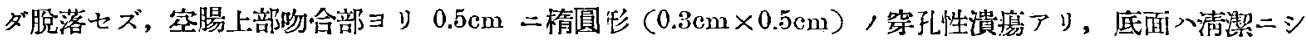

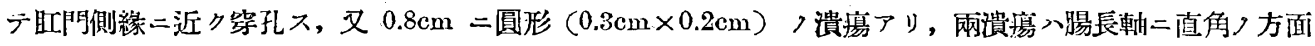


二伤發シ腸間膜附着部卜入關係ナク, 大網膜，瘾清アリ，何レモ周緣入隆起シ急峻ナリ，兩視瘍，下方約

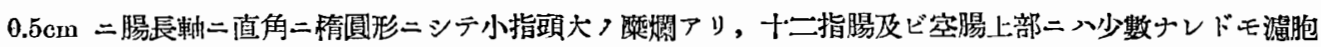
著明二肥大ス其他二八著變习認メズ。組織學的所見，胃粘膜二八圆形細胞つ輕度ノ浸潤アルモ基底部細胞 , 配列正シク殖ド尋常ナリ, 粘膜筋及ビ粘膜下織二モ著變ナク筋層入萎縮シ染色二濃淡アリ, 獎膜, 肥厚

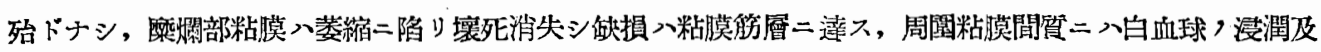
ビ充血アルモ出血入認メズ，該部粘膜間質入重度，浮腫狀

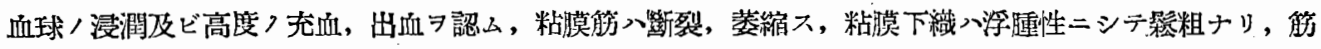

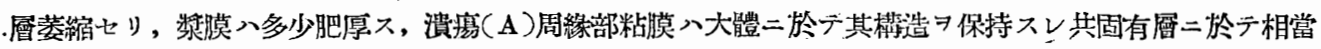

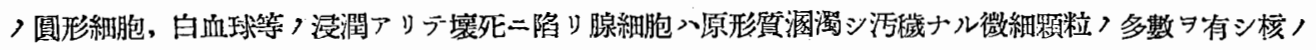

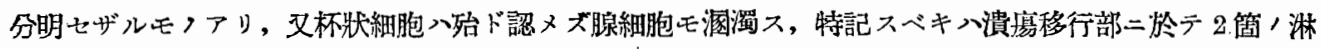

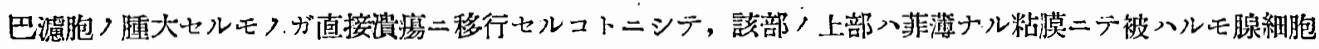
八壞死二陷ル, 粘膜下織入肥厚シ移行部濾胞〉下部入白血球, 淋巴球〉浸潤アリ, 䇟尿入處々娄縮シ移行

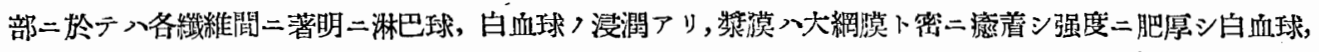
圓形細胞及ビ少數ナルモ「プラスマ、細胞等ノ浸润著明ナリ，該部血管壁モ肥厚シ多量，血液允盈ス，是等

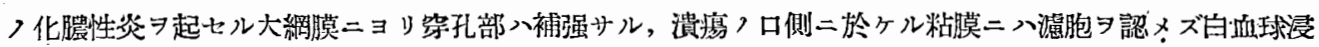

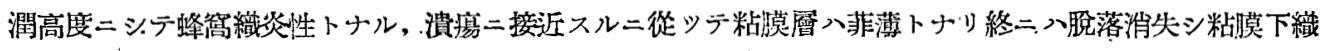

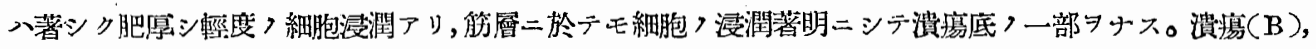

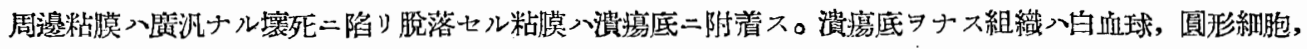

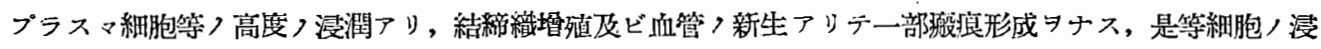

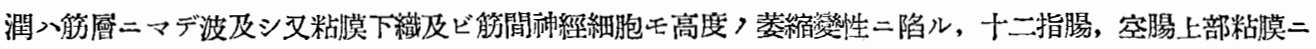
於ヶル淋巴湢胞入著明二腫脹ス。

Nr., 39, 令, 10.6kg.,

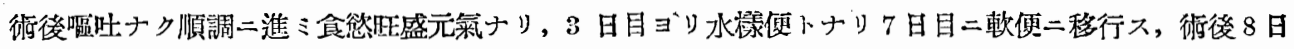

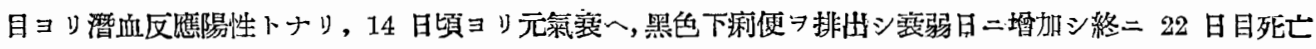

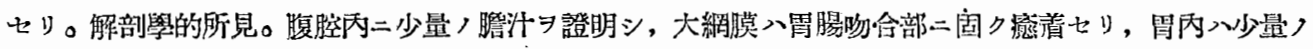
粘液アルノミニシテ火ンタ變化ヨ認メズ, 十二指腸入菲薄ニシテ少量ノ粘液アリ, 胃腸吻合部入完釜二㽷

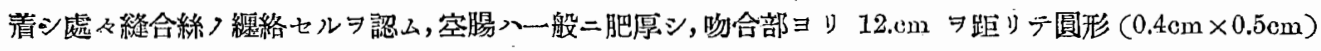

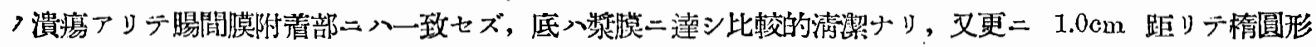
$(1.5 \mathrm{~cm} \times 0.8 \mathrm{~cm}) ，$ 潰瘍アリテ䀴門側二於テ穿孔シ腸，長軸ニ平行ニアリ腸閒膜二一致セズ存在ス，何レ モ上緣入著明二隆起ス，空陽下方，粘膜面二帶赤黑色，苔アリ，腸端侧吻合部二八著變ナシ。組織學的所

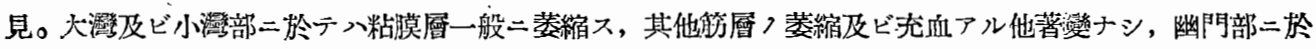

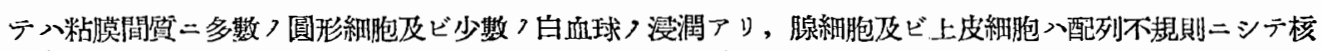

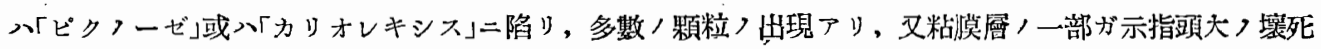

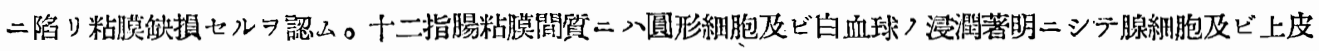

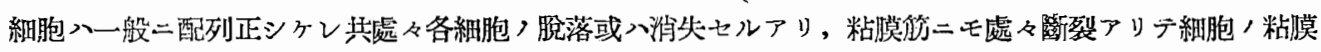

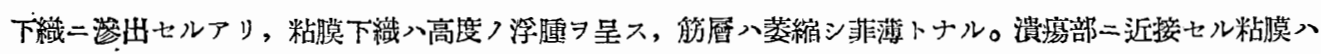

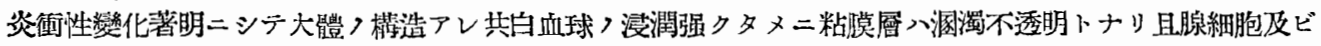

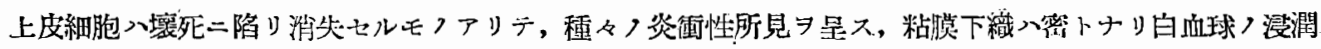

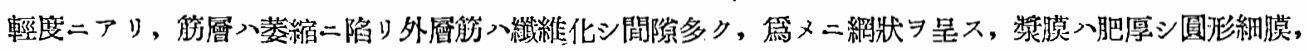

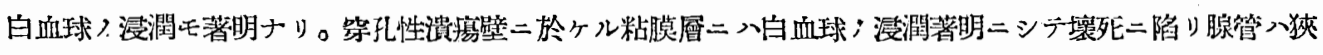
小ナガラ殘存シ腺細胞等既存細胞入污染サル, 粘膜下織及ビ筇層入肥厚シ白血球ノ浸潤著明二シテ壤死二

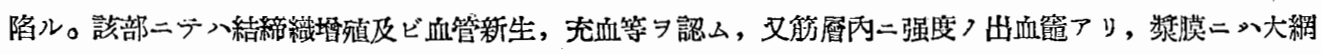




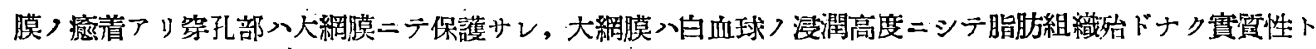

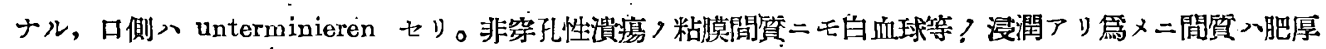
シ腺腔八狹小トナリ壞死二陷り潰㾤二移行セリ, 粘膜下織入密二肥厚シ細胞浸潤モ可成り高度ニアリ。潰

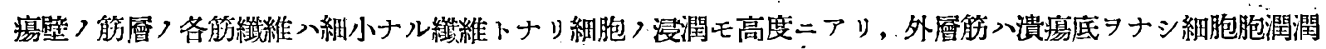

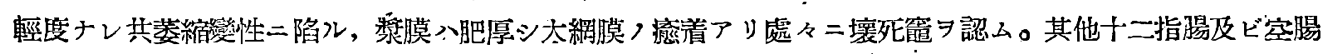
上部”八淋巴㯺胞, 腫大著明二認メラル。

Nr., $40, \hat{\delta}, 8.5 \mathrm{~kg}$.

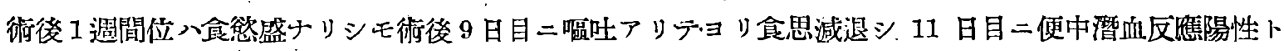
ナリ以來黑色下荊便ヨ排出シ衰弱著シク 18 日目二死亡ス。解剖學的所見, 腹腔內多量フ膯汁アリ大網膜

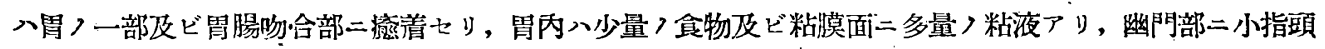

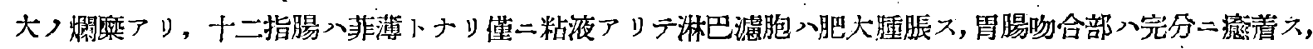

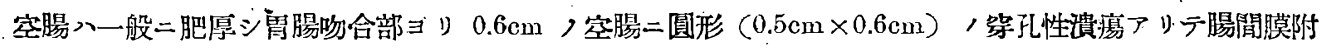

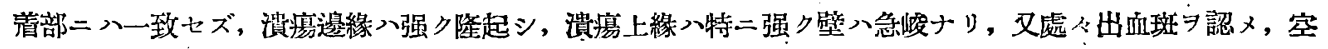
腸下部及ビ迥腸二モ處々黑赤色, 戴塊アリ, 腸端側吻合部二八著戀ナシ。組織學的所見。大灣部粘漠二於 テン壁細胞及ビ主細胞ノ配列正シク固有層二八細胞浸潤殆ドナケレ共幽門部ニ於デ輕度つ細胞浸潤アリ テ腺細胞〉脫落，核つ消失或入細胞自體〉消失等アリ粘膜層入著シク菲溥トナリ粘液ヨ以テ被包セラル，

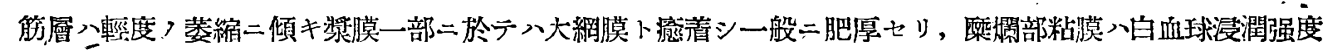

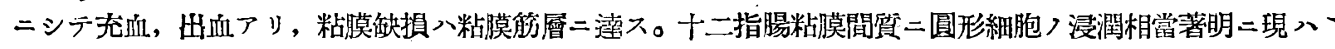
レ毛細血管入允盈セリ，腺細胞配列正シク杯狀細胞入多數出現シ腺腔內ハ粘液ヨ容レ上皮細胞入不規則二 配列シ脫落セルモフ多シ, 朌層八各緟維染色, 濃淡著シク萎縮變性二陷ル, 漿膜多少肥厚セり。潰瘍近接 部空腸粘膜入炎㣫性變化著明ニシテ, 白血球及ビ圓形細胞ノ强度，浸潤アリ，充血シ，該部八腺細胞壊死

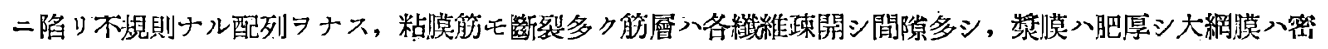

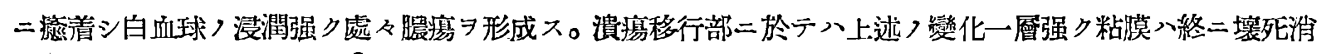
失シ，粘膜下織モ密二肥厚シ白血球等，浸潤强ク壞死トナリ又筋層二於テモ細胞浸潤强ク壞死變性シ繊細

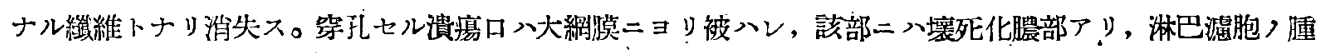

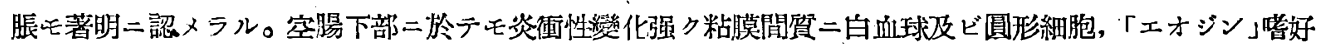

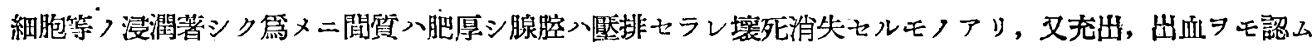
筋層入菱縮變性シ漿膜入殆ド肥厚セズ。

Nr., $48, \%$, $6.5 \mathrm{~kg}$.

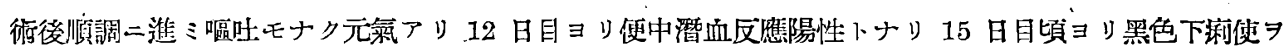
排出シ元氣衰一次第二哀弱增加シ術後 20 日目二死亡セり。解剖學的所見，腹腔內多量，膿汁アリ胃腸吻

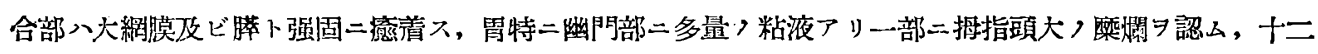
指腸入菲溥ニシテ比較的多量 粘液

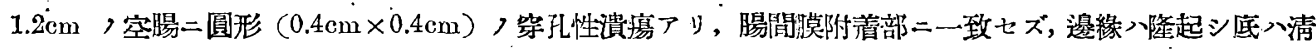

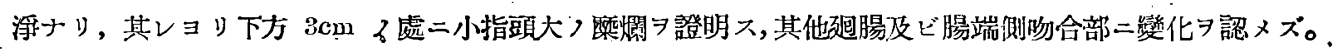

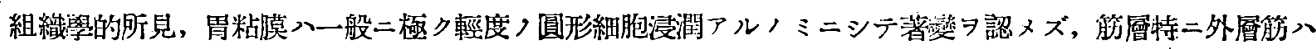

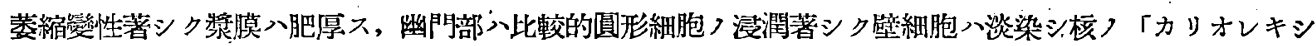
ス」著キモノアリ，主細胞八核つミ残存、シ胞體つ溶解セルアリ，上皮細胞入粘液二テ被ハル。十二指腸粘

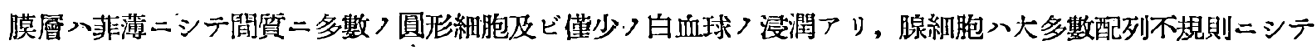
各原形質入下明瞭トナり或入溶解シ核つミ殘存スルアリ，核入「ピクノーゼ」或入溶解等種々・變性所見

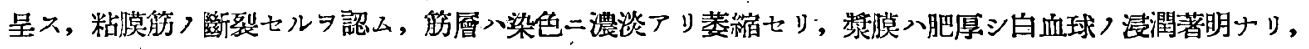

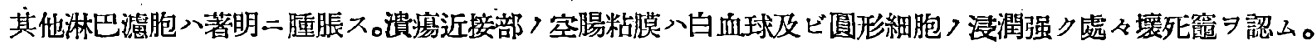




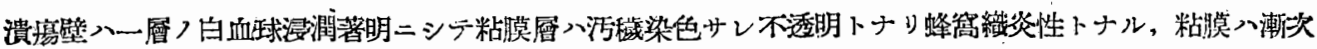

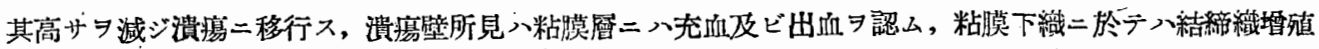

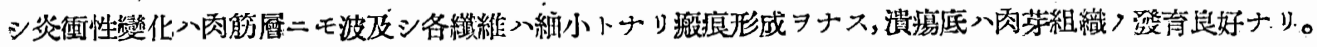

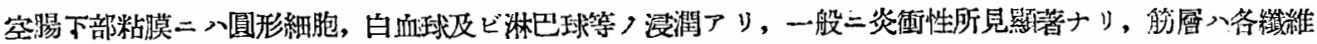
中腔得トナリ萎縮坴性ス。

\section{弟 3 節 術式第 1 群ノ聜驗成績小括 \\ 第 1 項 術後一般狀態}

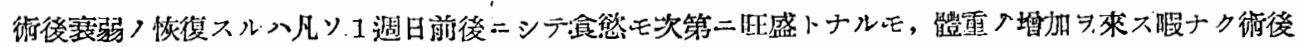

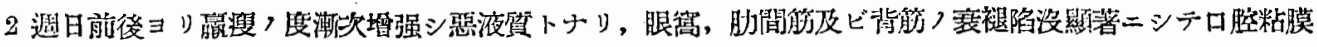

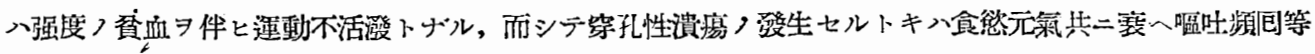

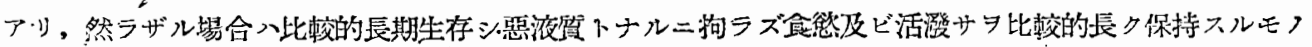
ナリ。

\section{第 2 項 大便 / 性狀}

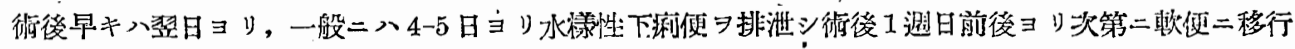

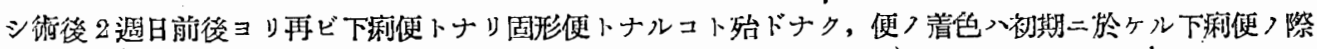

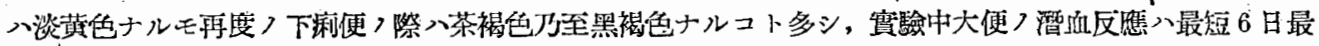

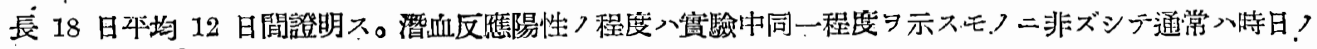
經過ニッレテ反應增强スルモ途中二於テ弱陽性乃至陰性トナリ後再ビ壖强スルコルアリ，而シデ該反應陽

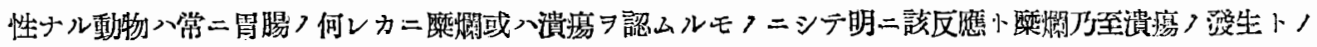

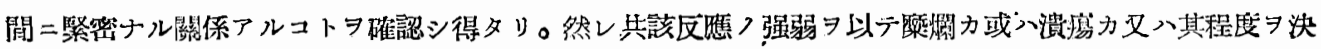
定スル尺度トハナシ得ズ。

\section{第 3 項 腹 堙內 所見}

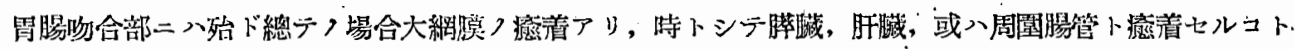

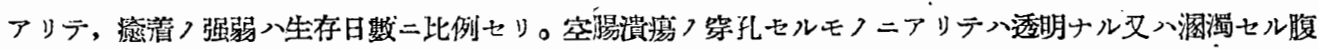

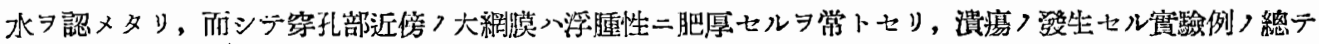

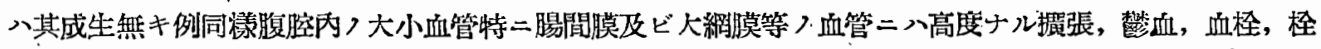

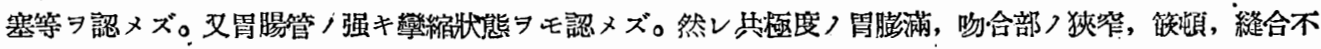
、全ニョル急性化膿性腹膜炎等ヨ少數例二於テ認メタリ。縫合絲入殆ド凡テ，例ニ於デまが脫落セズ吻合部

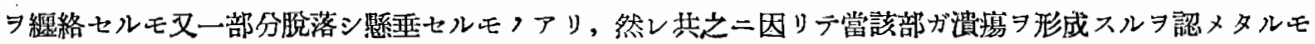
ノナシ。

\section{第 4 項 潰 㑥}

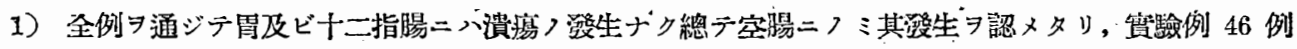

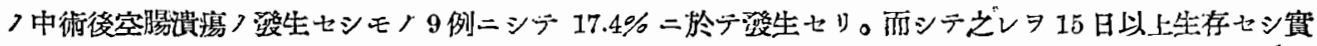

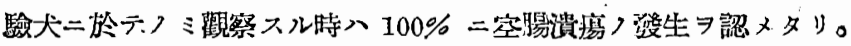

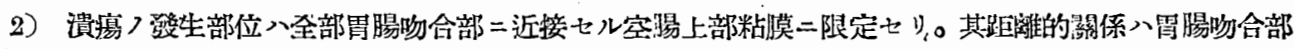

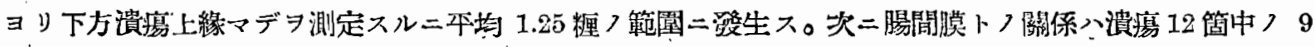

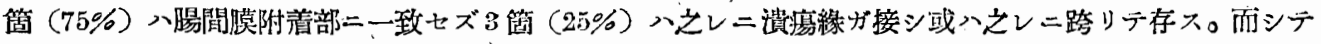

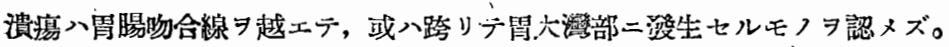

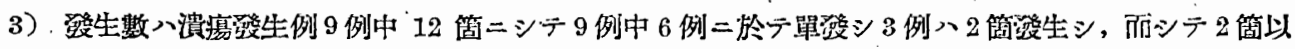
上多墢セルモフナシ。

4）谓瘍成生

5）肉眼的性狀 形態入一般二圓形或入楕圓形ニシテ周園粘膜下〉境界八明膫ナリ, 其周緣入隆起七 
ルモノフ多ク, 上綠入下緣ニ比シ一般二高度二隆起シ且ツ銳角ヨナシテ. unterminieren 七ルモノ多ク, 下緣

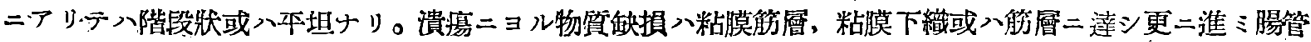

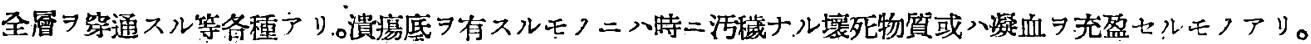

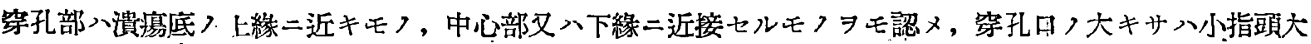
ヨリ睤ク認メ得ル程度つモ广アリ。

\section{第 5 項 糜 䪍}

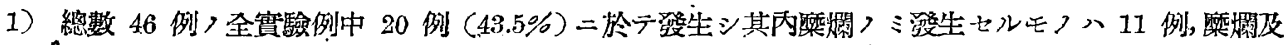
ビ虫瘍习做波セルモフ 9 例ナリ。

2）發生部位及ビ發生數，主トシテ胃室腸粘膜二發生シ十二指腸粘膜ニハ1例アルニ過ギズ。胃粘膜二

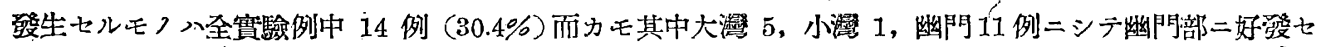

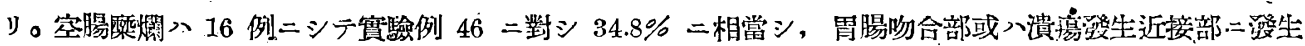

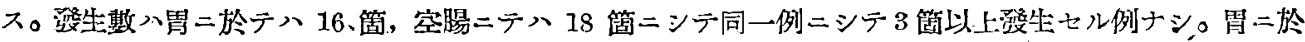

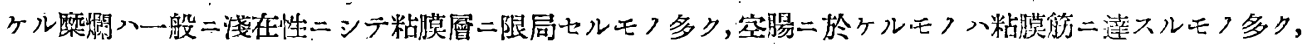

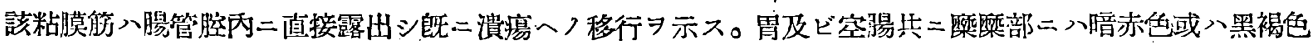

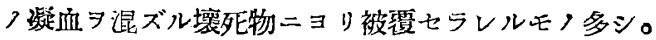

\section{第 6 項 淋 巴滤胞}

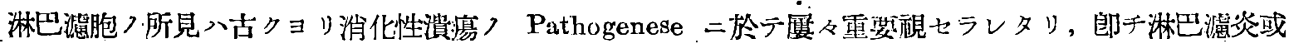

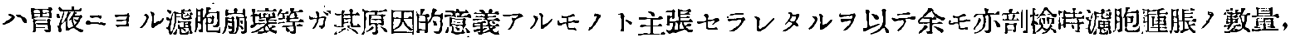

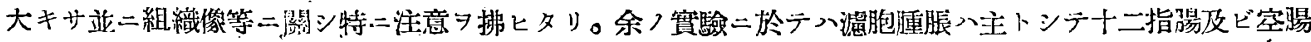
上部粘膜二認メラ.レ, 空腸上部ニ於テハ胃腸吻合部ヨリ距ル程輕度トナリ下部腸管二八認入難シ。郎于實 第 1 表 衔式第一群／解割所見總括

\begin{tabular}{|c|c|c|c|c|c|c|c|c|c|c|c|c|c|c|c|c|}
\hline 動 & 術 & 性 & 生 & 術算 & 鉋 & & 漬 & & & & & 糜 & 爛 & & & \\
\hline 物 & $\begin{array}{l}\text { 前 } \\
\text { 體 }\end{array}$ & & & 便出 & 使 & 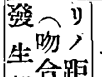 & & 形 & $\begin{array}{l}\text { 穿 } \\
\text { 的 }\end{array}$ & $\begin{array}{l}\text { 造 } \\
\text { 緣 }\end{array}$ & \begin{tabular}{|l|} 
腸關 \\
紗
\end{tabular} & $\begin{array}{l}\text { 稵 } \\
\text { 生 }\end{array}$ & 穴。 & 濾 & 當 & \\
\hline $\begin{array}{l}\text { 密 } \\
\text { 號 }\end{array}$ & $\begin{array}{c}\text { 重 } \\
(\mathrm{kg})\end{array}$ & 別 & 数 & 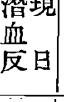 & $\begin{array}{l}\text { 有 } \\
\text { 热 }\end{array}$ & 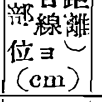 & $\begin{array}{c}\# \\
(\mathrm{~cm})\end{array}$ & 狀 & $\begin{array}{l}\text { 有 } \\
\text { 繁 }\end{array}$ & $\begin{array}{l}\text { 隆 } \\
\text { 起 }\end{array}$ & 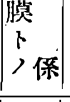 & $\begin{array}{l}\text { 部 } \\
\text { 位 }\end{array}$ & & $\begin{array}{l}\text { 阯 } \\
\text { 位 }\end{array}$ & 數 & $\begin{array}{l}\text { 穴 } \\
\text { サ }\end{array}$ \\
\hline 1 & 8.8 & 우 & 2 & & + & & & & & & & & : & |十二指腸| & 少 & 小 \\
\hline 2. & 10.5 & 우 & 2 & & + & & & & & & & & & 十二指腸 & 少 & 中 \\
\hline 3 & 10.3 & $\hat{\delta}$ & 3 & . & + & & & & & & & & & & & \\
\hline 4 & 14.0 & o & 30 & 7 & - & 2.01 & $1.0 \times 0.8$ & 圆形 & + & + & - & 空腸上部 $\mid$ & 帽針頭二氺 & 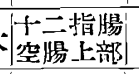 & 多 & 天 \\
\hline 5 & 10.0 & $\hat{\delta}$ & 3 & & - & & & & & & & & & 一二指腸 & 少 & 中 \\
\hline 6 & 7.8 & 우 & 7 & & + & & & & & & & & & 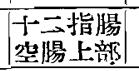 & 少 & $\begin{array}{l}\text { 大 } \\
\text { 中 }\end{array}$ \\
\hline 7 & 13.0 & 우 & 10 & 8 & $\dot{+}$ & & & & & & & 空腸上部 & 小指頍大 & 党腸上指腸 & 䒚 & 小 \\
\hline 8 & 11.0 & 우 & 11 & .7 & - & & & & & & & 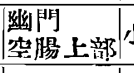 & 小指頭火 & 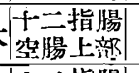 & 多 & 火 \\
\hline 9 & $9: 0$ & $\hat{o}$ & 7 & & + & & & . & & & & 空腸上部| & 小指頍大 & 厈卉二指腸 & 䒚| & $\begin{array}{l}\text { 太 } \\
\text { 中 }\end{array}$ \\
\hline 10 & 9.0 & $\hat{o}$ & 4 & & + & & & & & & & & & & . & \\
\hline 11 . & 8.6 & $\hat{o}$ & 6 & & - & & & & & & & & & 党二指腸上部 & 少 & $\begin{array}{l}\text { 小 } \\
\text { 小 }\end{array}$ \\
\hline 12. & 9.2 & 우: & 9 & 6 & + & & . & & & $\therefore 1$ & & 空腸止部， & 小指頭大 & 十二指腸 & 少 & 小 \\
\hline
\end{tabular}




\begin{tabular}{|c|c|c|c|c|c|c|c|c|c|c|c|c|c|c|c|c|}
\hline 13 & 9.7 & 우 & 7. & & + & & . & & & & & & & $\left|\begin{array}{l}+ \text { 空腸_指腸 } \\
\end{array}\right|$ & 少 & $\begin{array}{l}\text { 小 } \\
\text { 小 }\end{array}$ \\
\hline 14 & 10.0 & $\hat{0}$ & 23 & 7 & $t$ & 1.0 & $0.3 \times 0.3$ & 圆形 & - & + & + & 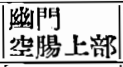 & $\begin{array}{l}\text { 嗗針頭大 } \\
\text { 小指頭大 }\end{array}$ & 支二指腸 & \begin{tabular}{|l|} 
少 \\
\end{tabular} & $\begin{array}{l}\text { 中 } \\
\text { 中 }\end{array}$ \\
\hline 15 & 7.2 & $\hat{o}^{\circ}$ & 2 & & - & & & . & & & . & &. & $\begin{array}{l}\text { 十二指腸 } \\
\text { 空腸上部 }\end{array}$ & \begin{tabular}{|l|} 
少 \\
\end{tabular} & $\begin{array}{l}\text { 小 } \\
\text { 小 }\end{array}$ \\
\hline 16 & 6.8 & $\hat{\partial}$ & 2 & & - & & & & & & & . & .. & & & \\
\hline 17 & 7.5 & 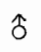 & 3 & & + & & & $1-$ & & & & & & & & \\
\hline 18 & 13.2 & 우 & 8 & 7 & + & & & & & & & 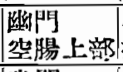 & $\begin{array}{l}\text { 小指頭大 } \\
\text { 拇指頭火大 }\end{array}$ & 空二揚上揚 & 少 & 中 \\
\hline 19 & 8.0 & $\hat{\jmath}$ & $\begin{array}{l}9 \\
-\end{array}$ & 6 & - & & & & & r & & 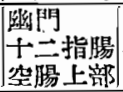 & 小指頭大 & $\mid \begin{array}{c}\text { 千二指腸 } \\
\text { 棸腸_上部 }\end{array}$ & 少 & $\begin{array}{l}\text { 小 } \\
\text { 中 }\end{array}$ \\
\hline 20 & 11.0 & 우: & 15 & 6 & - & 0.5 & $0.7 \times 0.9 \mid$ & 棈圆殁 & - & + & - & 尖灣 。 & 帽針䕱火 & $\mid \begin{array}{l}\text { 千云指腸 } \\
\text { 空腸上部 }\end{array}$ & 少 & $\begin{array}{l}\text { 中 } \\
\text { 中 }\end{array}$ \\
\hline 21 & 7.5 & $\hat{\delta}$ & 3 & & + & & $\bullet$ & & & & & & $: \quad:$ & $\left|\begin{array}{l}\text { 十二指腸 } \\
\text { 空腸上部 }\end{array}\right|$ & 多 & $\begin{array}{l}\text { 中 } \\
\text { 中 }\end{array}$ \\
\hline 22 & 13.0 & 우 & 11 & 8 & + & & & & . & $=$ & & 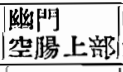 & 帽針頍大 & 千二指晹 & 多 & $\begin{array}{l}\text { 大 } \\
\text { 中 }\end{array}$ \\
\hline 23 & 6.8 & $\hat{\delta}$ & 5 & & - & & - & & & & & . & $1:=$ & $\mid \begin{array}{l}\text { 十指腸 } \\
\text { 案腸上部 }\end{array}$ & 多 & 兴 \\
\hline 24 & 7.0 & 우 & 7 & 6 & - & - & . & & & . & & & & $\mid \begin{array}{c}\text { 空腸上指腸 } \\
\mid\end{array}$ & 少 & $\begin{array}{l}\text { 小 } \\
\text { 小 }\end{array}$ \\
\hline 25 & 10.4 & $\hat{o}$ & 8 & 8 & - & . & & & & & & - & & & & \\
\hline 26 & s.7 &.$\hat{\delta}$ & 11 & 9 & + & & & & & & & 空腸上部 & 损指頭大 & $\mid \begin{array}{c}\text { 十空脂腸上部 } \\
\mid\end{array}$ & 䒚 & $\begin{array}{l}\text { 中 } \\
\text { 中 }\end{array}$ \\
\hline 27. & 9.6 & 우 & 2 & & + & & - & & & & & & & 十二指腸| & 少 & 小 \\
\hline 28 & 10.2 & 후 & 7 & & - & & & & & & & & & 二指腸 & 少. & 小 \\
\hline .29 & 10.6 & 우 & 21 & 12 & + & 1.0 & $1.5 \times 08 \mid$ & 棈圆形 & + & + & - & \begin{tabular}{|l|} 
小潅 \\
空腸上部
\end{tabular} \mid & $\begin{array}{l}\text { 小指頭大 } \\
\text { 小指頭大 }\end{array}$ & $\begin{array}{l}\text { 十二指腸 } \\
\text { 空腸上部 }\end{array}$ & 多 & $\begin{array}{l}\text { 中 } \\
\text { 犬 }\end{array}$ \\
\hline 30 & 13.4 & $\hat{\jmath}$ & 6 & & + & & & 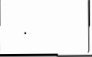 & & & & & . & 空腸，上部 & 少 & 小 \\
\hline 31 & 9.0 & 우 & 9 & 6 & - & & & & & & & 次灣 & 小指頭大 & 千二指腸 & 少 & 中 \\
\hline 32 & 15.6 & $\hat{o}$ & 2 & & - & & & & & & & & & $\left|\begin{array}{l}1 \text { 二指腸 } \\
\text { 空腸上部 }\end{array}\right|$ & 少 & 小 \\
\hline 33 & 10.4 & 우 & 38 & 18 & + & $\begin{array}{l}1.0 \\
1.5 \\
\end{array}$ & {$\left[\begin{array}{l}0.5 \times 0.6 \\
0.3 \times 0.3\end{array} \mid\right.$} & 圓形 & \pm & 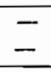 & \pm & $\begin{array}{l}\text { 大灣幽梐 } \\
\text { 㘳腸_上部 }\end{array}$ & $\begin{array}{l}\text { 小指頭大 } \\
\text { 幅針頭火大 }\end{array}$ & 志二指腸 & 多 & $\begin{array}{l}\text { 大 } \\
\text { 犬 }\end{array}$ \\
\hline .34 & 11.6 & $\hat{O}$ & 52 & $10^{-}$ & + & $\begin{array}{l}0.5 \\
0.8 \\
\end{array}$ & $\begin{array}{l}0.3 \times 0.5 \\
0.2 \times 0.2\end{array}$ & 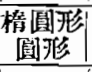 & \pm & $\begin{array}{l}+ \\
+\end{array}$ & \pm & 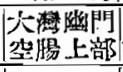 & 小指頭大 & 䒚二指腸上部 & 䒚 & $\begin{array}{l}\text { 大 } \\
\text { 大 }\end{array}$ \\
\hline 35 & 10.8 & $\hat{\delta}$ & 34 & 11 & - & & & & & & & |空腸上部 $\mid$ & 小指頭大 & 古二指晹 & 少 & 大 \\
\hline 36 & 11.5 & 우 & 2 & & - & & & & & & & & - & |空腸上部 & 少 & 小 \\
\hline 37 & 11.8 & 우 & .8 & 6 & + & & & & & & & $\begin{array}{l}\text { 大湇 } \\
\text { 空腸_上部 }\end{array}$ & 小指頭大 & 十二指腸 & 少 & 小 \\
\hline 38 & 10.8 & q & 3 & & - & & & & & & & . & & 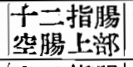 & 少 & $\begin{array}{l}\text { 小 } \\
\text { 小 }\end{array}$ \\
\hline 39 & 10.6 & $\hat{o}$ & 22 & 8 & - & $\begin{array}{l}1.0 \\
1.2 \\
\end{array}$ & $\mid \begin{array}{l}1.5 \times 0.8 \\
0.4 \times 0.5\end{array}$ & 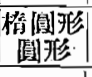 & + & $\begin{array}{l}+ \\
+ \\
\end{array}$ & $=$ & 踘門 & 示指頭大 & 空云腸上部 & 多 & 大 \\
\hline 40 & 8.5 & $\hat{\delta}$ & 18 & 11 & + & 0.6 & $|0.5 \times 0.6|$ & 圆形 & + & - & - & 幽附 & 小指頭大 & $\left|\begin{array}{|c|c|c|}\text { 十空腸上腸 } \\
\end{array}\right|$ & 多 & 穴 \\
\hline 41 & 12.8 & $\hat{\delta}$ & 6 & & + & - & & & & & & & & $\mid$\begin{tabular}{|} 
千二指腸 \\
空腸上部
\end{tabular} & 䒚 & $\begin{array}{l}\text { 小 } \\
\text { 小. }\end{array}$ \\
\hline 42 & 10.3 & 우 & 2 & & + & & & & & & & & & & & \\
\hline 43 & 6.5 & 우 & 20 & 12 & + & 1.2 & $0.4 \times 0.4 \mid$ & 圓形 & - & + & - & 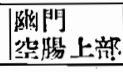 & 拇指頭大 & 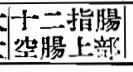 & 少 & $\begin{array}{l}\text { 火 } \\
\text { 犬 }\end{array}$ \\
\hline
\end{tabular}




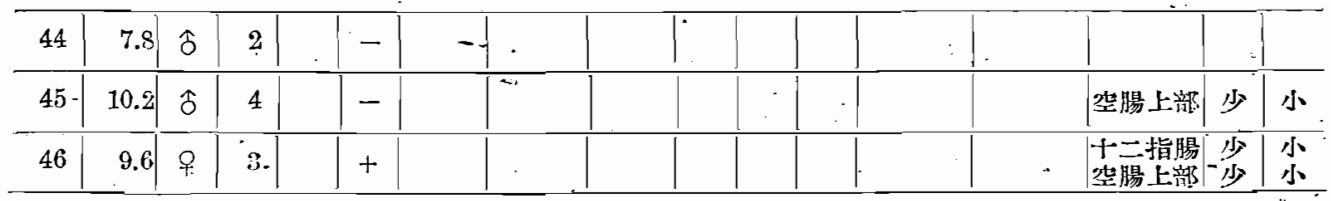

驗例 46 例中 39 例 $(84.8 \%)$ 二之レ 認メ, 其中 36 例 $(78.3 \%)$ 八十二指腸 $=, 31$ 例 $(67.4 \%)$ 八空腸 粘膜二認メタリ, 文十二指腸度ビ空腸上部粘膜二例發セルモ， 28 例 $(60.9 \%)$ ナリ, 而シテ是等フ發生

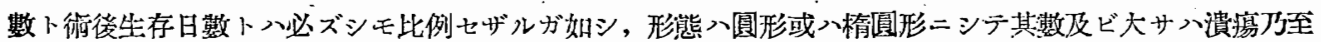

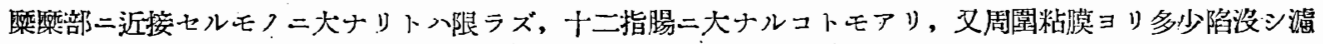

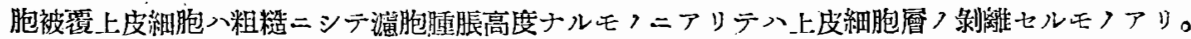

今上計セル解部所見习表示ハレバ第1表つ如シ。

第 7 項 胃, 空腸, 十二指腸粘膜ノ組織學的所見

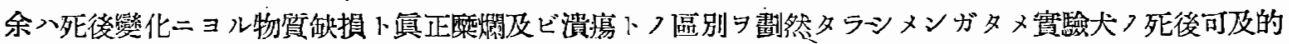

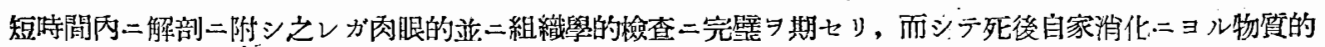

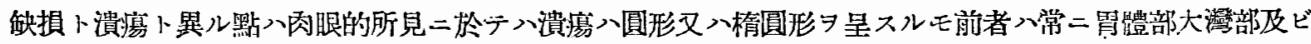

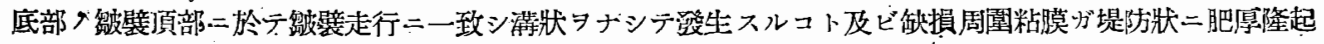
シ，嘪火口狀ヨ呈スル:反シ，後者二八斯カル所見ナキコト組織學的所見二於テハ前者二八其周園組織 ニ炎重性及ビ修覆性變化ヨ必ズ證明スルニ㧦ラズ後者ニハ全ク之レヨ認メ得ザルコト等ニョリ兩者ヨ明二 區別シ得。

第。2 表 . 術式第一群，胃腸粘膜組織學的所見總括

· ( Ht. 著明, t十 中等度, 十 輕度, 一 無)

\begin{tabular}{|c|c|c|c|c|c|c|c|c|c|c|c|c|c|c|}
\hline \multirow{3}{*}{$\begin{array}{l}\text { 動 } \\
\text { 物 } \\
\text { 番 } \\
\text { 號 }\end{array}$} & \multirow{3}{*}{$\begin{array}{l}\text { 生 } \\
\text { 存 } \\
\text { 日 } \\
\text { 数 }\end{array}$} & \multicolumn{2}{|c|}{ 䒚 } & 偒 & \multicolumn{2}{|c|}{ 部 } & \multicolumn{2}{|c|}{ 胃 } & 阴 & 部 & \multicolumn{2}{|c|}{+} & \multirow{3}{*}{\multicolumn{2}{|c|}{$\begin{array}{l}\text { 腸 } \\
\text { 出 } \\
\text { 血 }\end{array}$}} \\
\hline & & 細浸 & 冭 & 出 & 溃 & ・糜 & 細浸 & 态 & 活 & 糜 & 細浸 & 态 & & \\
\hline & & 胞潤 & 血 & 血 & 瘍 & 關 & 胞潤 & 血 & 血 & 爛 & 胞潤 & 血 & & \\
\hline 1 & 2 & $t$ & + & - & - & - & - & - & - & - & - & - & & - \\
\hline 2 & 2 & + & - & - & - & - & + & + & + & - & + & - & & - \\
\hline 3 & 4 & $t+$ & - & - & - & - & + & + & - & - & - & - & & - \\
\hline 4 & 30 & ttt & Ht & H & + & + & tt & + & + & - & tt & - & & - \\
\hline 5 & 3 & + & - & - & - & - & - & + & - & - & - & - & . & - \\
\hline 6 & 7 & tt & + & $t$ & - & $f$ & + & + & - & - & + & + & & - \\
\hline 7 & 10 & $+t$ & + & + & - & + & it & + & - & - & + & + & & - \\
\hline 8 & 11 & $t+$ & $\mathrm{tt}$ & $+t$ & - & + & $t$ & + & + & + & + & - & & - \\
\hline 9 & 7 & $t$ & + & + & - & + & + & + & - & - & tt & + & & 7 \\
\hline 10 & 4 & + & + & + & - & - & - & - & - & - & - & - & & - \\
\hline 11 & 6 & + & - & - & - & - & - & - & - & - & + & - & & - \\
\hline 12 & 9 & H & + & + & - & + & + & - & - & - & t† & - & & - \\
\hline 13 & 7 & + & + & + & - & - & + & - & - & - & + & - & & - \\
\hline 14 & 23 & HI & Ht & tt & + & + & + & + & + & $+^{\circ}$ & \# & - & & - \\
\hline 15 & 2 & $\stackrel{1}{-}$ & - & - & - & - & - & $\therefore$ & - & - & - & - & & - \\
\hline 16 & 2 & H & + & + & - & - & - & - & - & - & - & - & & - \\
\hline 17 & 3 & - & - & - & - & - & - & - & - & - & - & - & & 一 \\
\hline is & 7 & $\mathrm{ttt}$ & + & + & - & + & + & + & + & + & - & $=$ & & - \\
\hline 19 & 9 & tt & + & + & - & + & + & + & + & + & $H$ & + & & + \\
\hline 20 & 15 & tt & H & H & + & + & tt & $\mathrm{Ht}$ & + & $t$ & . & - & & 一 \\
\hline 21 & 3 & + & - & - & - & - & + & + & + & - & + & - & - & - \\
\hline 22 & 11 & tf. & + & - & - & + & 圤 & + & + & + & + & - & & 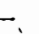 \\
\hline 23 & 5 & + & - & - & - & - & - & - & -- & - & + & - & & - \\
\hline 24 & 7 & + & + & + & - & - & - & - & - & - & - & - & & - \\
\hline 25 & 8 & 卅 & + & + & - & - & + & + & - & - & + & - & & - \\
\hline
\end{tabular}




\begin{tabular}{|c|c|c|c|c|c|c|c|c|c|c|c|c|c|}
\hline 26 & 11 & H & + & + & - & + & H & + & - & - & + & - & - \\
\hline 27 & $\stackrel{2}{2}$ & + & - & - & - & - & - & - & - & - & $\dot{-}$ & - & - \\
\hline 40 & 7 & $\pi$ & t. & $\stackrel{+}{+}$ & - & - & + & $\overline{I+}$ & - & - & ++ & - & - \\
\hline 29 & 21 & tif & IIf & III & $\stackrel{+}{-}$ & $\stackrel{+}{-}$ & $\stackrel{+}{-}$ & $\underline{-}$ & $=$ & $\bar{z}$ & \pm & $=$ & $=$ \\
\hline 31 & $\overline{9}$ & H & + & + & - & - & + & - & - & - & + & $T$ & - \\
\hline 32 & 2 & - & - & - & - & - & - & - & - & $\div$ & - & - & - \\
\hline 33 & 33 & H & H & 曲 & + & + & $\pi$ & + & + & + & + & + & + \\
\hline 84 & $58-$ & H & H & 曲. & + & + & $\pi$ & + & + & + & + & + & - \\
\hline 35 & 14 & m & Ht & $\pi$ & - & + & $t+$ & + & - & - & t十 & - & - \\
\hline 36 & 2 & + & + & + & - & - & + & + & - & - & + & t. & + \\
\hline 87 & 8 & tt & $\pi$ & $\pi$ & $=$ & 4 & + & - & - & - & + & - & - \\
\hline 38 & 3 & + & - & - & - & - & + & - & - & - & + & - & - \\
\hline 39 & 22 & H & $\mathrm{Ht}$ & H & + & - & tt & $\pi$ & + & + & + & - & - \\
\hline 40 & 18 & HI & $\#$ & $\pi$ & + & - & 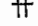 & + & + & + & + & - & - \\
\hline 41 & 6 & + & + & - & - & - & + & $\pi$ & + & - & + & + & - \\
\hline 42 & 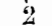 & & - & - & - & . & - & - & - & - & $\tau$ & - & - \\
\hline 43 & 20 & 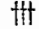 & .tt & H & + & + & $\pi$ & + & + & + & + & - & - \\
\hline 44 & 3 & $i$ & $\overrightarrow{+}$ & $\bar{I}$ & $=$ & - & $\overline{ \pm}$ & $=$ & 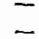 & $\overline{-}$ & $=$ & $=$ & - \\
\hline 46 & 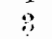 & + & + & + & - & - & - & - & - & $\leftarrow$ & + & + & - \\
\hline
\end{tabular}

次二詳細ナル組織學的變化八總括ニ於テ計述スベキモ本欄二於テハ幽門部，空腸上部，十二指腸粘膛閒

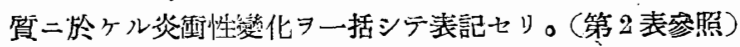

\section{第 8 項 胃及ビ腸管壁ノ組織學的所見}

詳細ハ後述センモ本項二於テ概要习述ベントス。

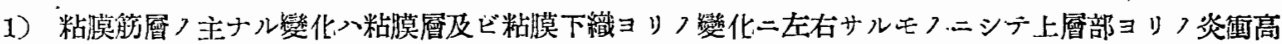

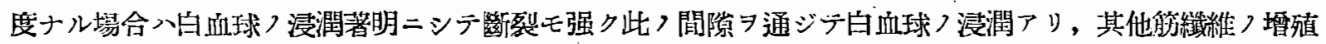
肥厚习モ認么。

2）殆ド總ベテフ粘膜下織ニ於テ認ムル變化、浮腫ヨ特長トシ，潰瘍近接部ハ特ニ之レガ著明ニシテ血・

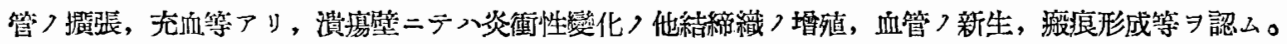

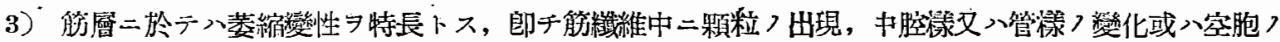
出琴等与認么。

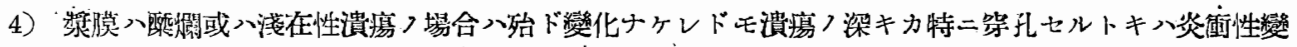
化或入燯㽝肥厚习認么。

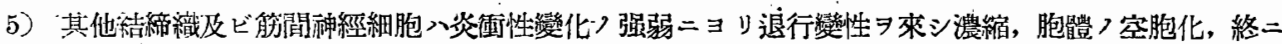
消尖セル习認ム。

\section{第 4 章 術式·第二群}

本術式群入胃並二腸潰瘍成生二對シ最モ意義深キモノト從來認メラレタル幽門液つ意義, 價値如何二關

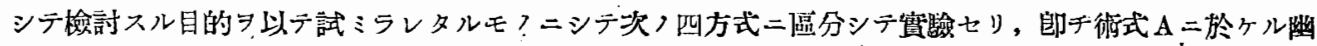

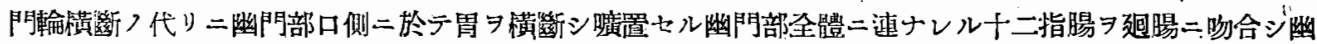

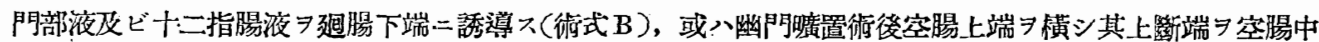

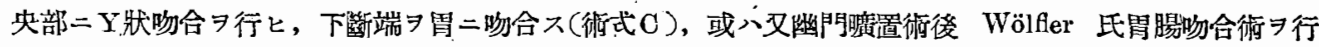

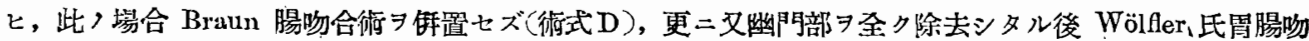

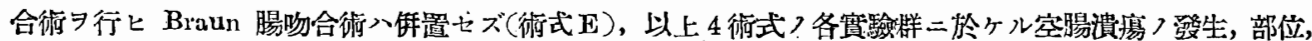

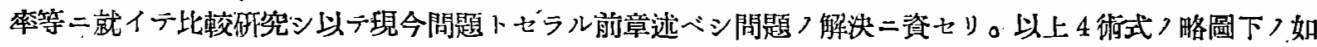
シ。

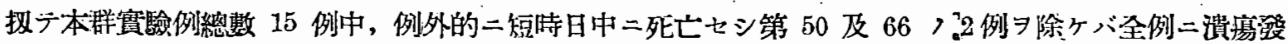
生ヨ認メタリ。從テュフ2 例入實驗成綪〉記述ヨ省略セり。 

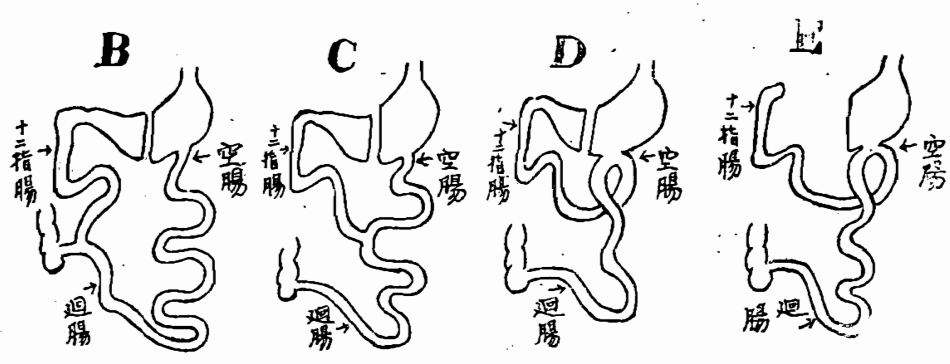

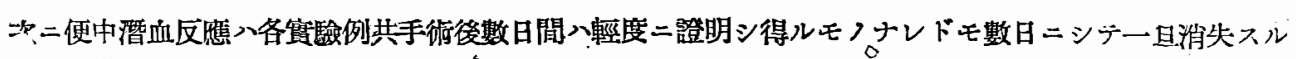

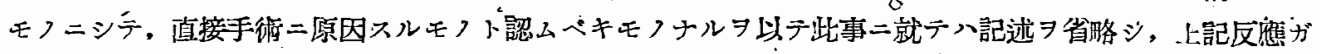

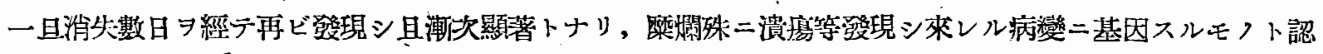

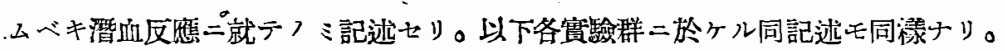

\section{第 1 節 術式 B J實驗成綪}

Nr., 47, 우, $7.2 \mathrm{~kg}$. ,

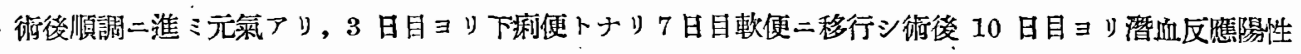
トナリ次第二衰弱著明トナリ, 15 日目頃ヨリ黑色便及ビ激シキ下麻便ヨ排出シ, 終ニ惡液質トナリ術後

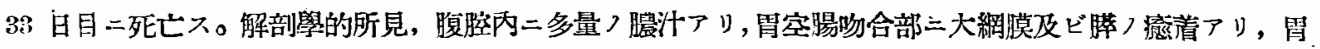

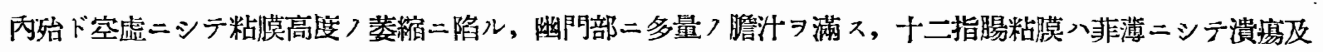

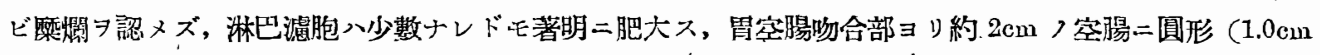

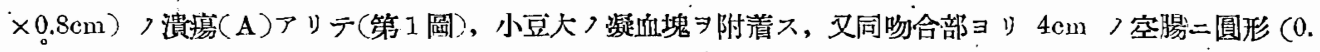

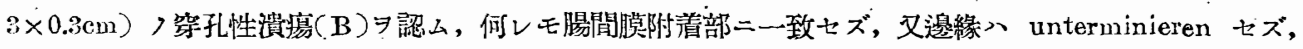

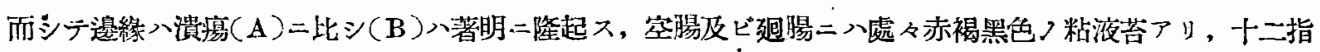

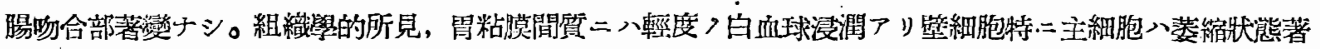

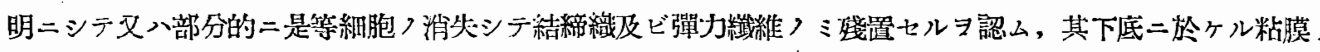

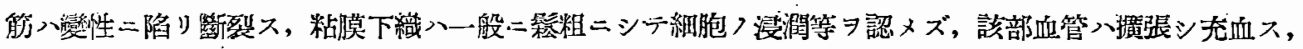

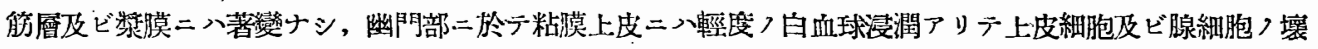
死ニ陷レルアリ。然レ共幽門腺基底部二入是等〉所見認メラレズ, 粘莫下織, 筇㸴等入著變ナク。十二指.

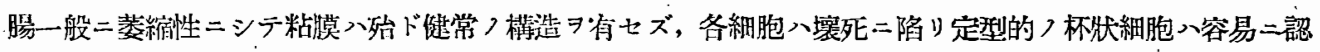

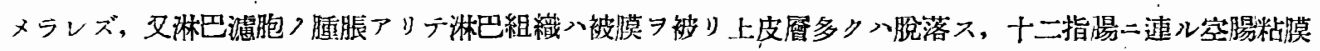

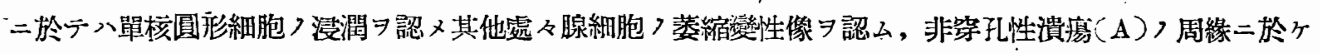
ル粘膜組織入大體二於テ其構造入保持サルルモ間質二八白血球，少數及ビ圓形細胞〉多數，浸潤アリ，腺 細胞入配列不規則ニシテ上皮細胞及ビ杯狀細胞、壞死セルモフ多數アリ是等壤死物質ニテ粘膜入被ハル，

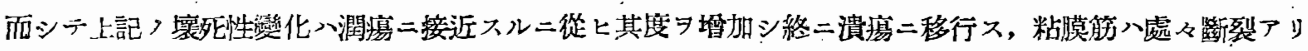

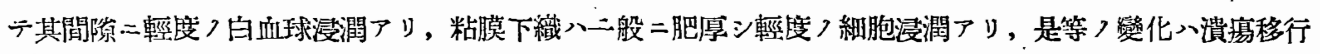

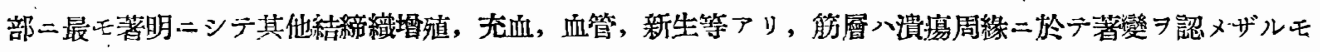

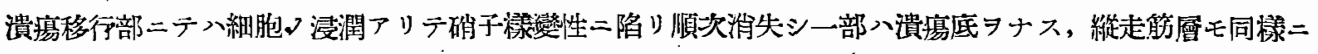

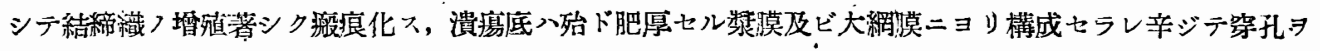

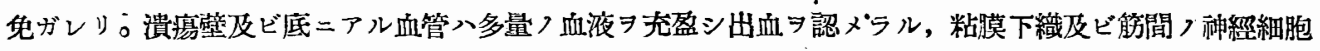

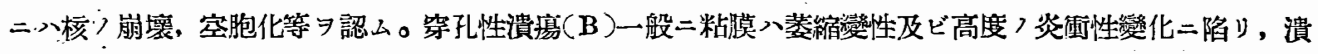

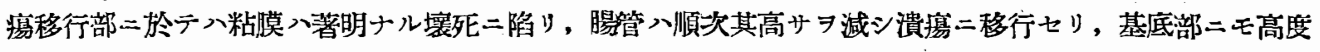

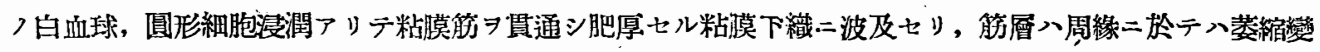

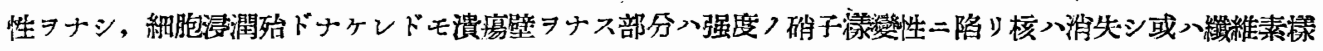




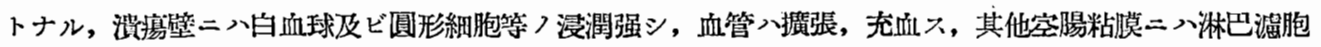
フ連脹セルヨ認ムルモ直接腸管內二露出セルモノナシ。

Nr., 48, $\hat{o}, 8.5 \mathrm{~kg}$.,

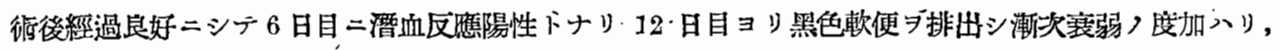

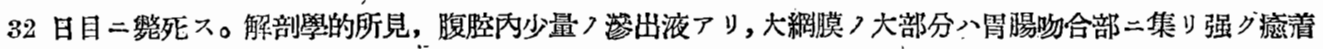

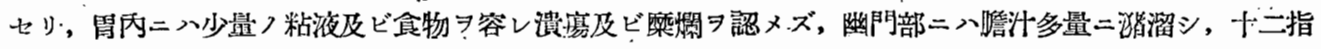
腸壁入菲薄トナリ，淋巴濾胞つ肥厚著明ナリ。胃空晹吻合部 ヨリ $0.5 \mathrm{~cm}=$ 卯圓形 $(2.0 \mathrm{~cm} \times 1.0 \mathrm{~cm})>$ 潰

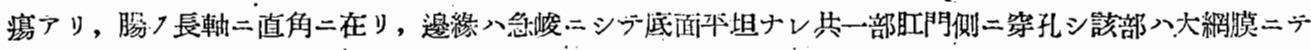

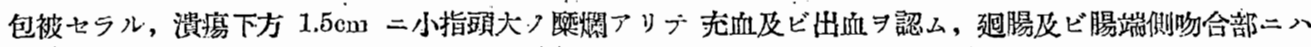

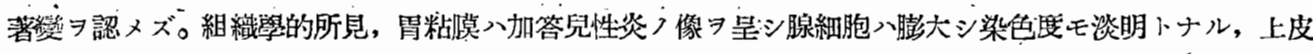
ニ八粘液ニヨリ被覆セラレ粘脱中二八腺細胞及ビ上波細胞入崩壤セルモつ及ビ少量フ白血球ヨ混ズ，粘膜

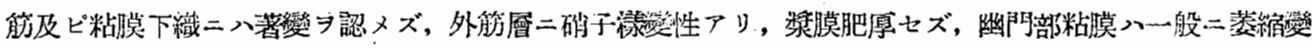

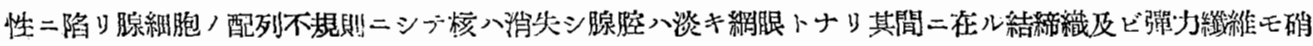

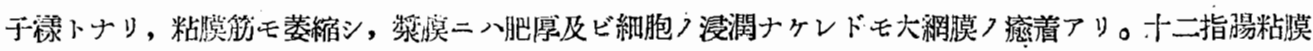

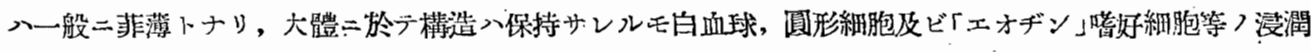

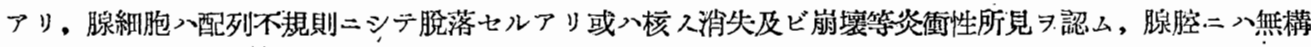

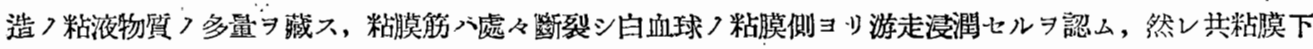

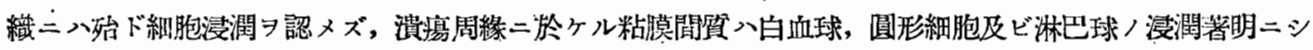

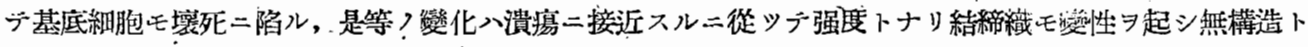

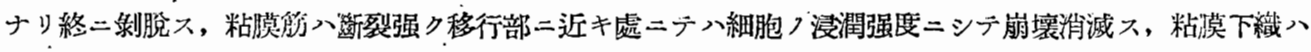

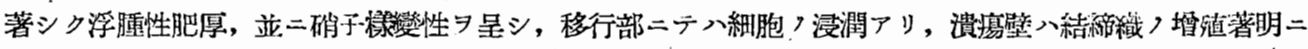

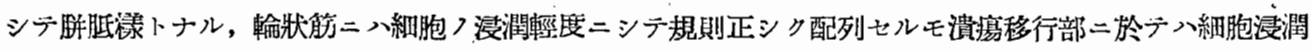

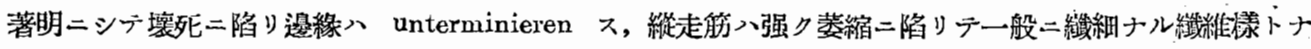

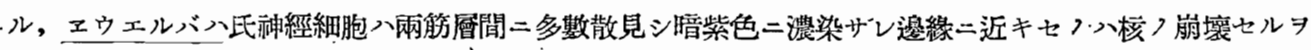

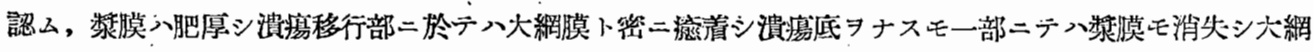

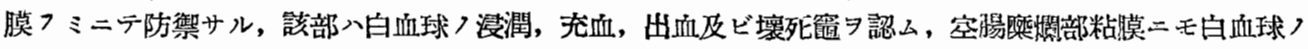

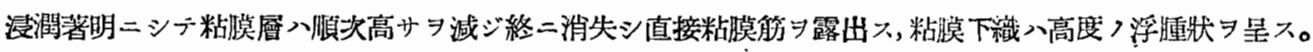
Nir., $49, \delta, 9.0 \mathrm{~kg}$.,

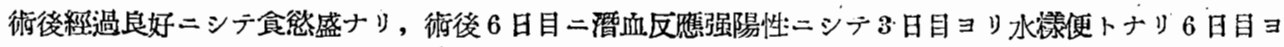

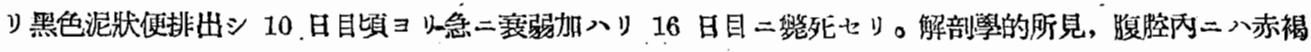

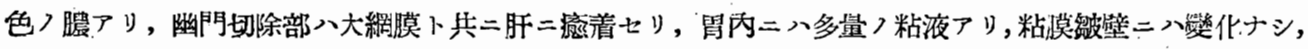

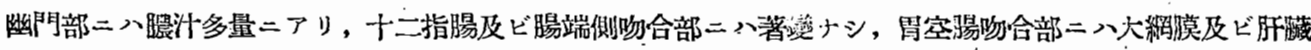

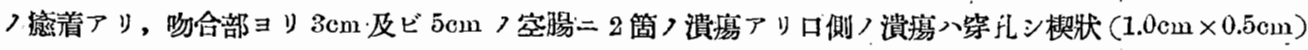

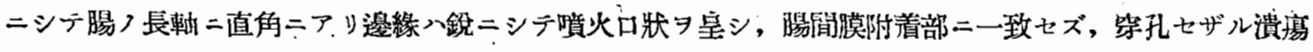

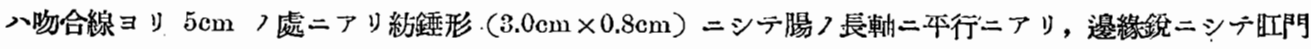

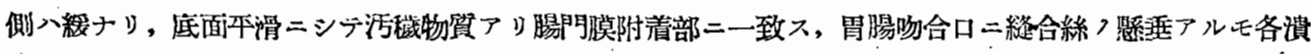

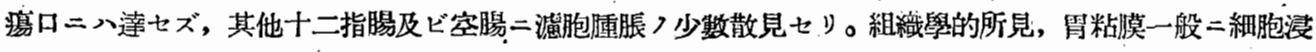
潤ナケレ共萎縮ニ陷リ主細胞及ビ壁緗胞つ排列不規則ニシテ主細胞入殆ド消失シ又壁細胞モ暗青色二染色

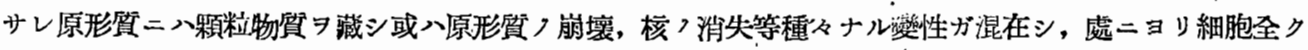

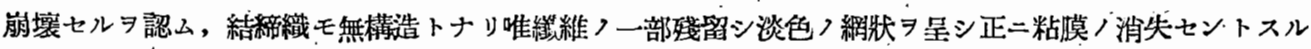

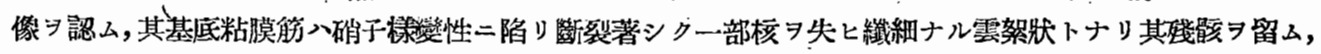

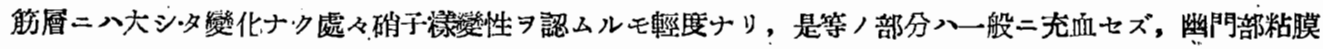


モ一般二腺細胞入不規則ニシデ脫落或入變性消失セルアリ，又一部ニテハ粘液變性二陷り腺腔內二多量〉

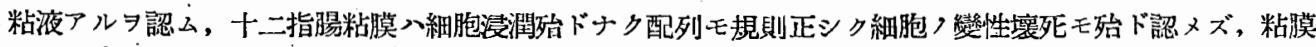

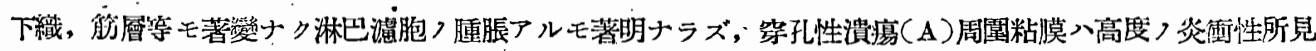
ヨ呈シ, 白血球, 圓形細胞及ビ淋巴球ノ浸潤アリテ間質入殆ド壞死二陷ル, 腺細胞ノ核ハ「ビグフーゼ」,

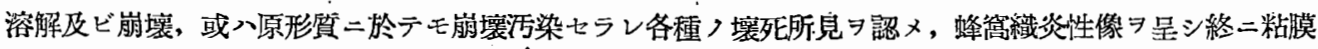

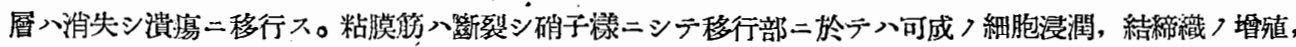

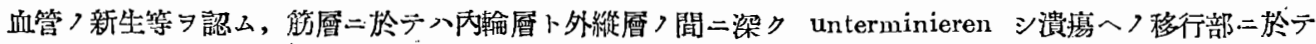

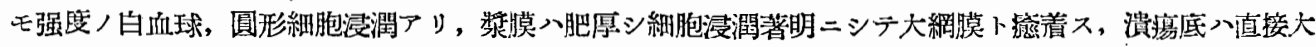

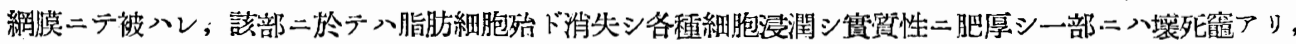

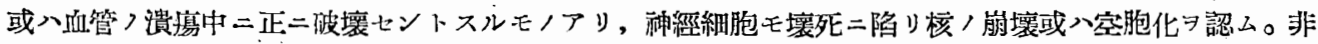

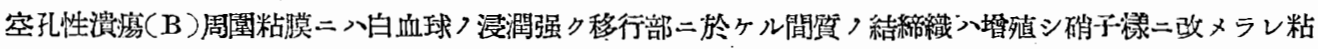

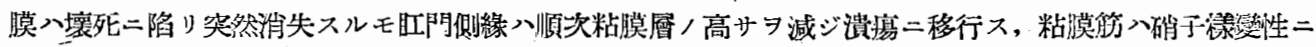

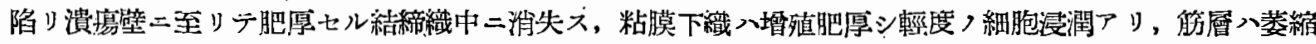
スレドモ移行部二於テフ輕度，細胞浸潤アリテ潰瘍底ヨナス，縱走筋入强度二萎縮シ菲薄トナル，浆膜入

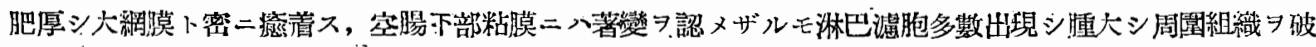
壞シ腸管臸二露出セルモノアリ。

Nr., 51 , 今, $9.5 \mathrm{~kg}$.,

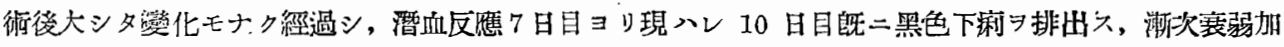

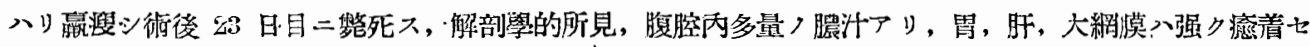

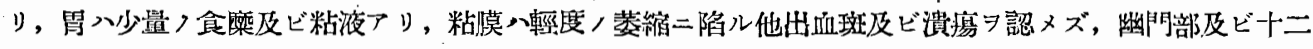

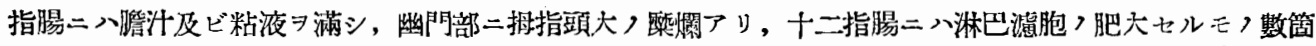
ヨ認ム, 胃空腸吻合部二溃瘍アリテ吻合部习越へテ胃ニハ達セズ, 空腸長軸二平行シ卵圓形 $(2.0 \mathrm{~cm} \times 0.8$

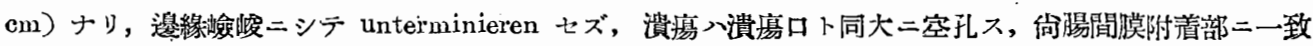

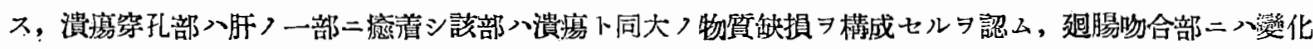
ヨ認メズ。組織學的所見，胃粘莫ハ大シタ變化ハ見ラレザルモ主細胞及ビ筀細胞つ原形筫內二顆粒狀物質 アリデ溶解シッ、アルモフアリ, 又核モ一部消失ス，筋層入萎縮シ其他著變ナシ。幽門部入萎縮高度二シ

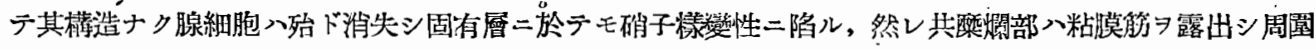

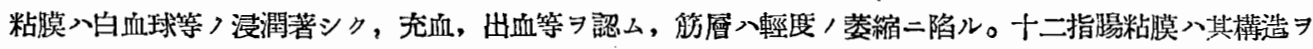

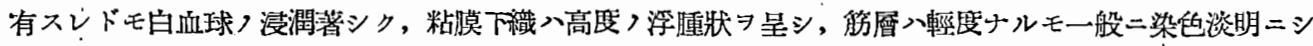

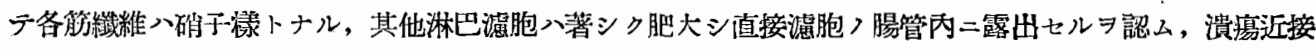
部粘膜二於テへ一般二白血球, 圓形細胞等, 浸潤高度ニシテ腺細胞二八顆粒>出現多ク，杯狀細胞入膨大 シ腺腔內二八粘液, 多量 $习$ 浯溜ス, 或入腺細胞ノ配列不規則ニシテ壤死二陷レルアリ, 移行部二於テ八構 造全クナク各細胞入壞死トナリ終二剥脫サる゙，粘膜下織及ビ等層つ移行部二於デハ細胞浸潤アリデ著シク

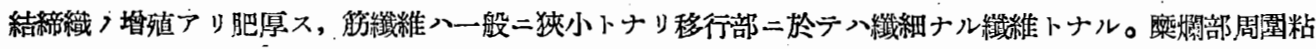
膜モ白血球 浸潤高度ニシテ壞死二陷ル。其他空腸上部二淋巴濾胞ノ腫脹シ粘膜上層部 剥脫アリ, 該部

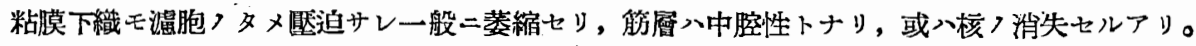

\section{第 2 節 術式 C ノ實驗成綪}

Nr., 52, 令； 10.5kg.,

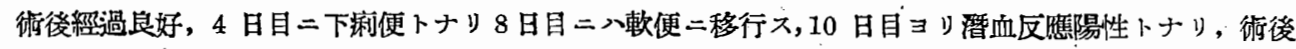

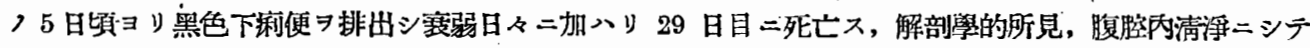

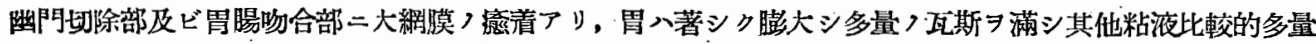

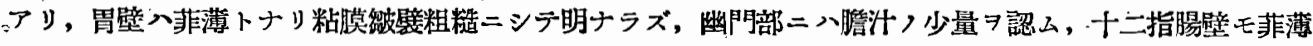




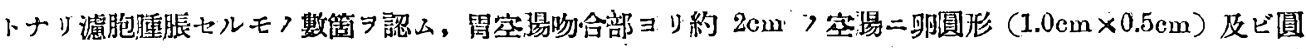

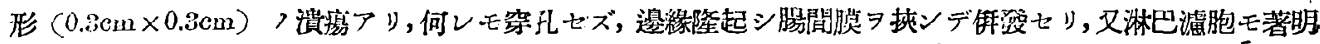

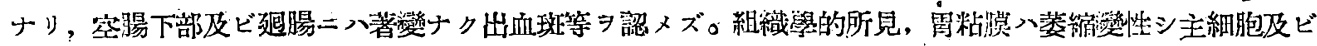

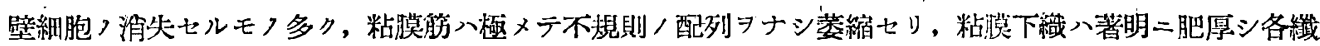

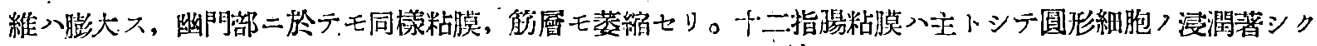

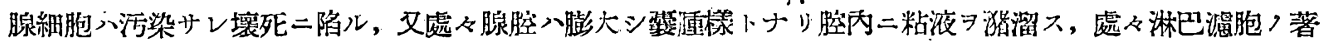

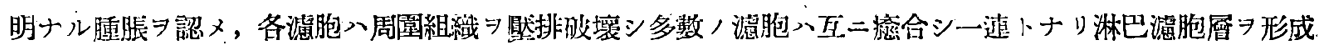

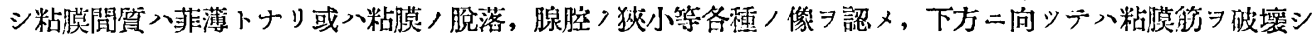

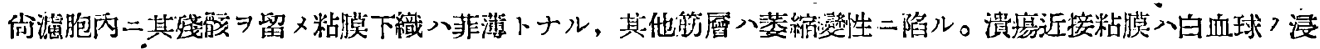

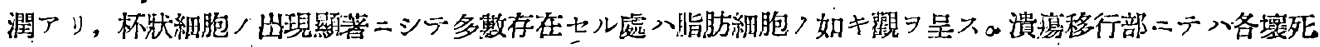

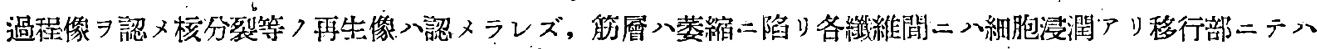

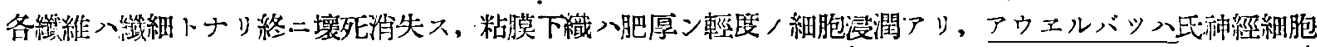

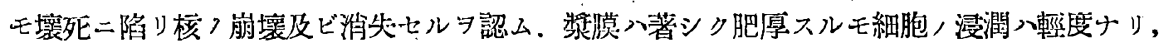

Ir., $54, \hat{\delta}, 11.0 \mathrm{~kg} .$,

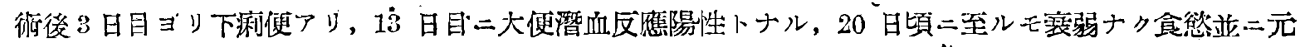

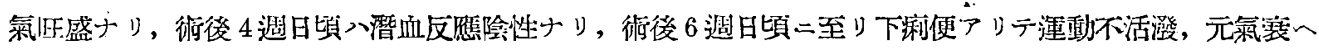

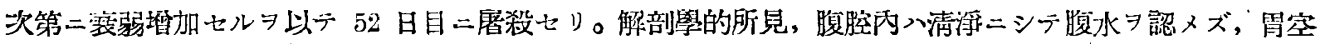

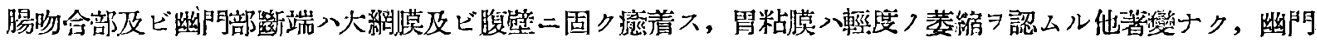

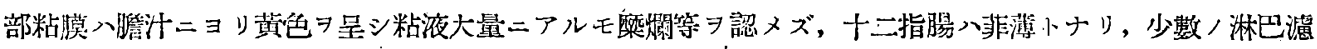

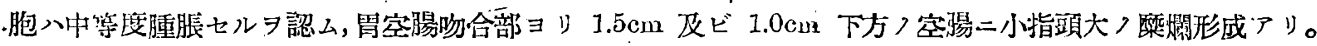

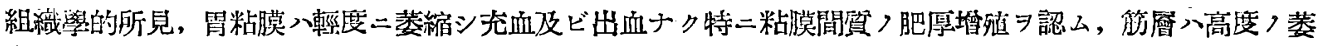
縮二陷ル。十二指腸粘膜入中等度二白血球, 圓形細胞等, 浸潤アリデ充血モ可成り認ムルモ出血ナシ, 滤

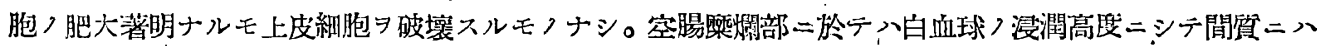

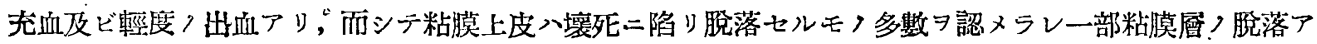

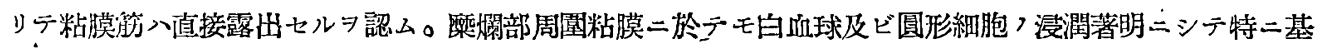
底部ニ於テ「エオジン」榙好細胞ヨモ認メラレ一般ニ充血ス, 粘膜下織入高度ノ浮腫狀ヨ呈シ該部血管モ充 血高度ナリ, 筋層入萎縮シ管樣トナル, 空腸二於ヶル淋巴濾胞入十二指腸ノ夫レニ比シ變化高度ニシテ上

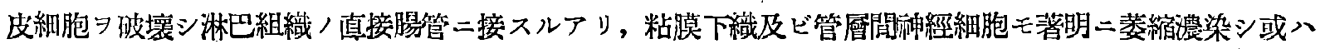
胞體, 崩壞, 消失等 7 認么。

$\mathbb{N} \times ., 55$,,$\quad 9.2 \mathrm{~kg}$,

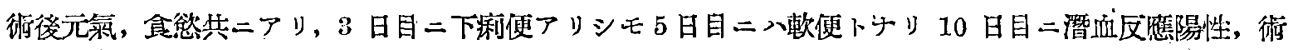

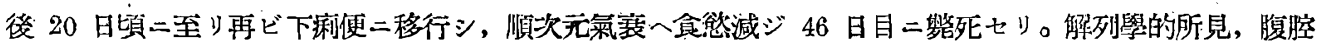

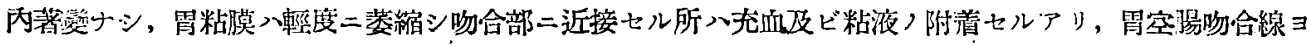
リ $0.8 \mathrm{~cm}$ 下方空腸二圓形 $(0.8 \mathrm{~cm} \times 0.7 \mathrm{~cm}) /$ 潰瘍アリ, 腸間膜附着部二一致シ, 邊線入隆起セズ粰慢二

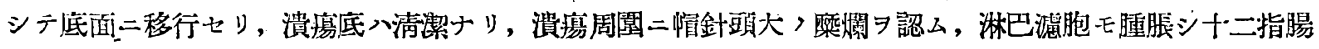

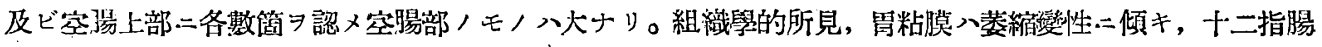

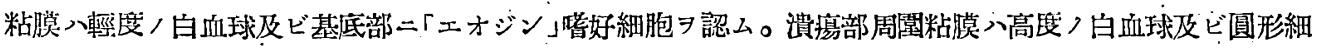

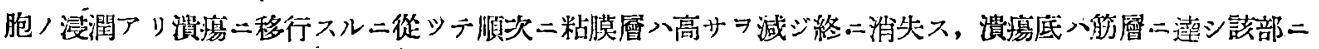

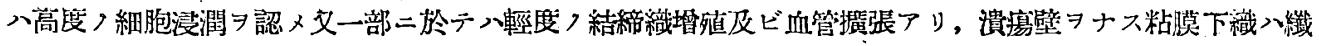

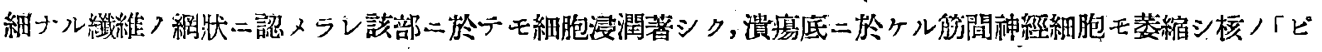
クフーゼ」ヨ認ム。(第 9 㘣)

\section{第 3 節 術式 D ノ實駼成績}


Nir., 56, $\hat{0}, 9.0 \mathrm{~kg}$,

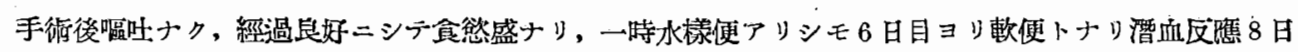

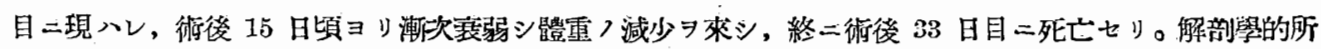

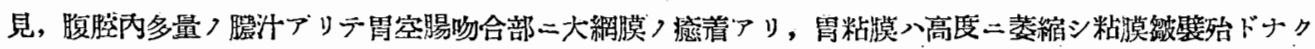

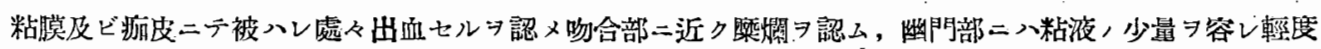

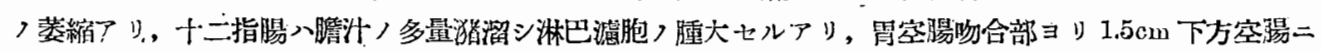

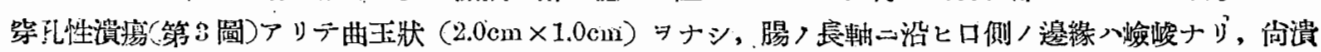

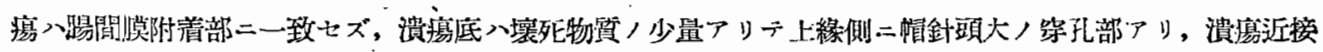

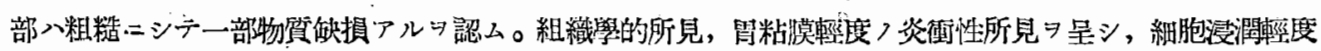

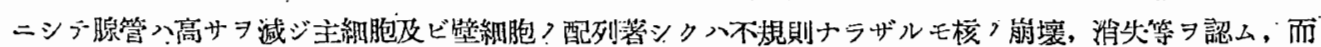

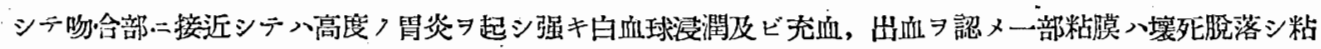

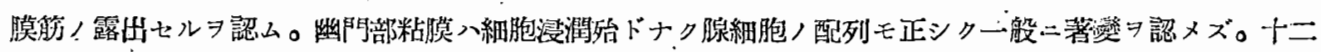

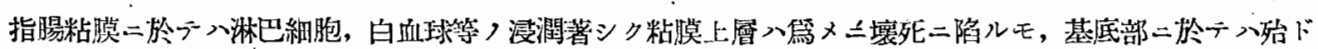

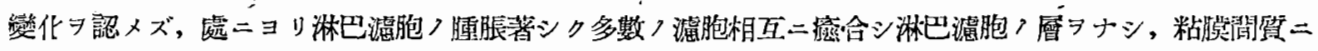
淋巴球〉浸润著シク腺腔入堅排サレ狹小トナリ或入消失シ，又晹管內二多數〉淋巴細胞ノ游走シ一部粘膜

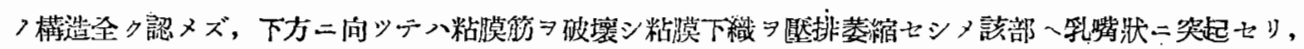

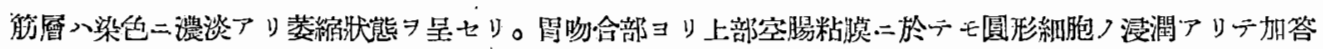

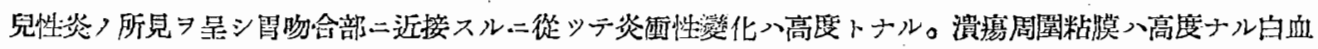
球, 淋巴緗胞其他〉浸潤アリ, 高度〉充血, 出血ヨ認ム, 一般=粘膜入污染不透明トナリ, 上層部入上皮

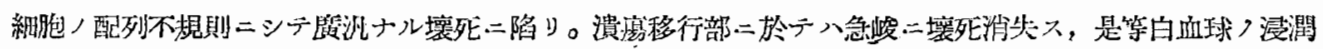

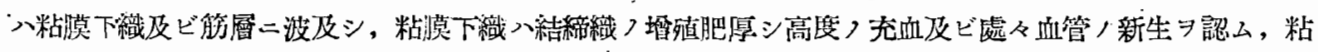

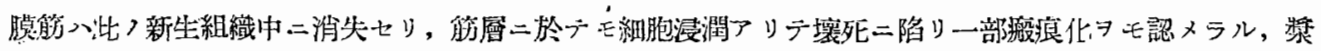

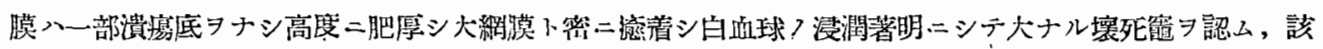

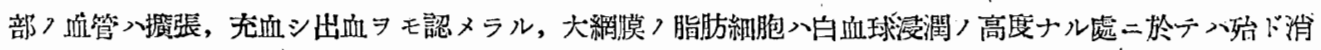

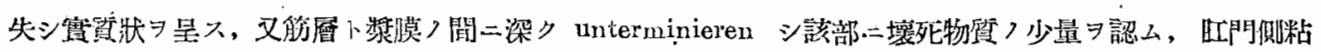

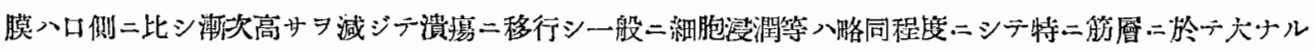

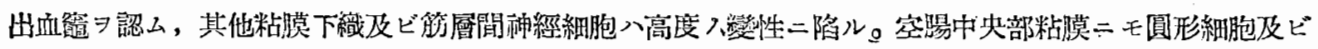
白血球ノ浸潤アリ又淋巴濾胞腫脹アリデ上皮細胞ノ壤死》認么。

Nir., 58 ; 令, $10.2 \mathrm{~kg}$.,

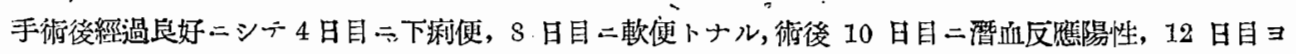

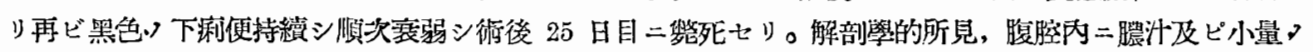
胃內容物アリ，胃粘膜入菲薄トナル，幽門及ビ十二指腸_上部入脆汁多量ニアリ其他滤胞つ腫脹セルフ認ム，

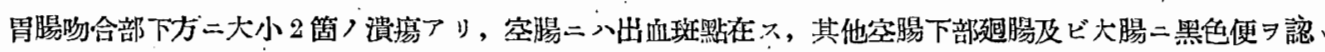

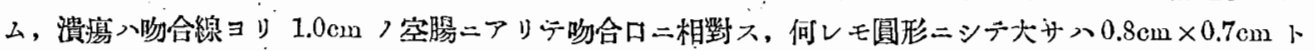
$0.3 \mathrm{~cm} \times 03 \mathrm{~cm}$ ナリ前者入呀孔シ周緣入隆起シ且多少嶮峻ナリ，溃瘍底入清浮ナリ，後者入紫孔セズ底面入

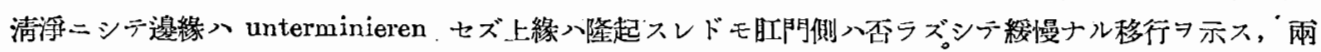

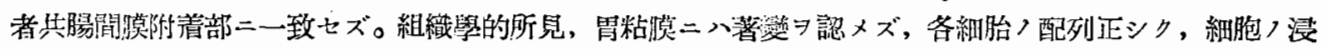

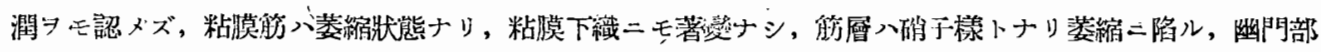

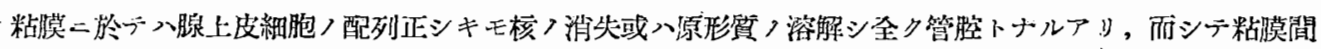

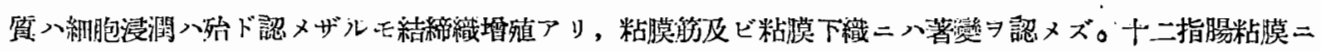

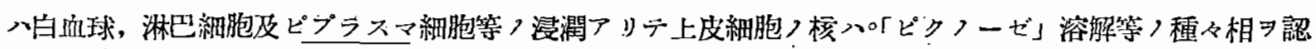

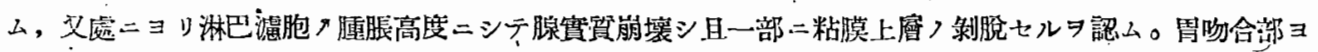




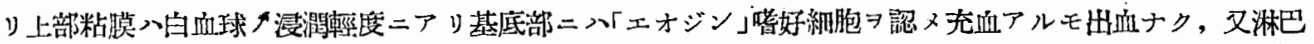

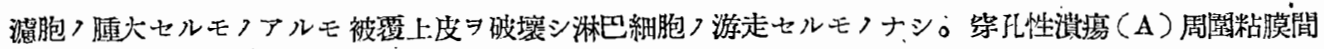

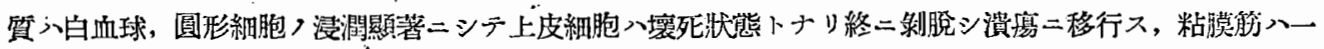

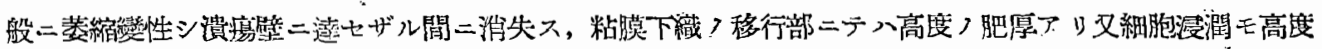

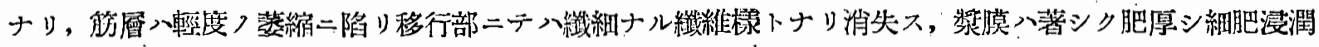

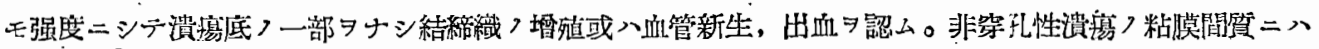

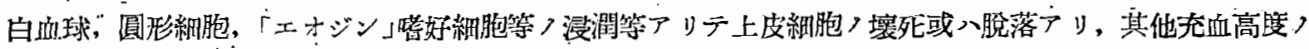

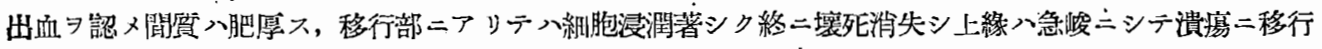

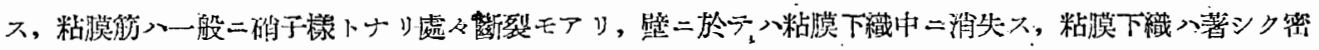

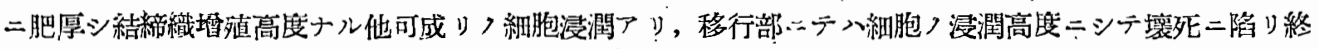

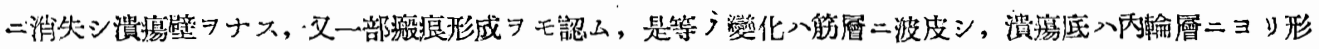

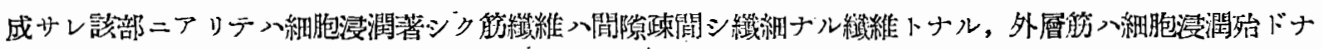

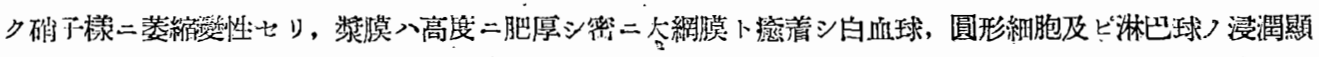

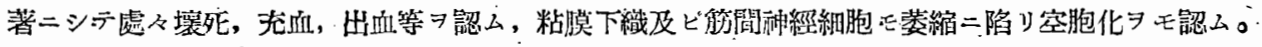

Nr., $59, .9,-10.0 \mathrm{~kg}$,

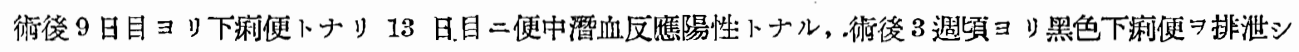
順次全身襄弱シ終二術後 46 日目二死ス。解剖學的所見, 腹腔內ニ「ューヒー樣液少量アリ, 胃壁入多少

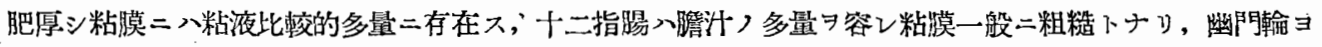

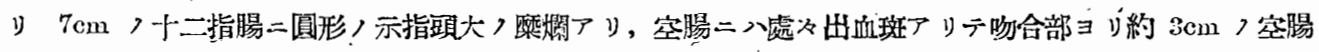

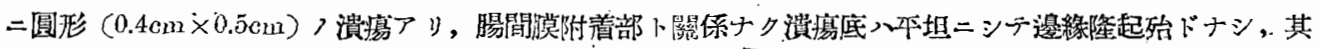

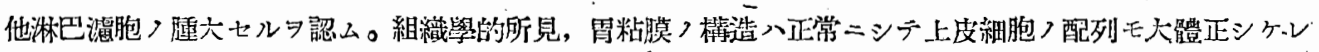

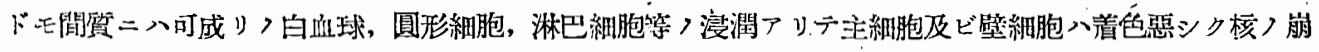

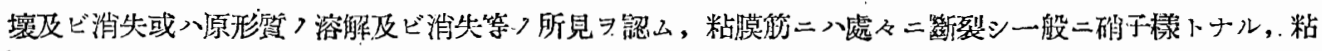

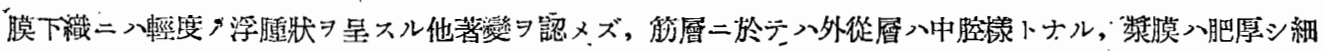

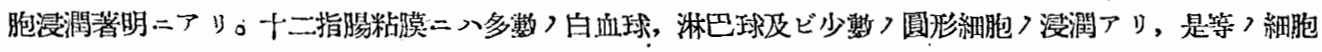

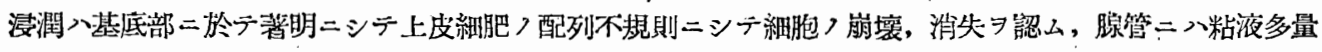

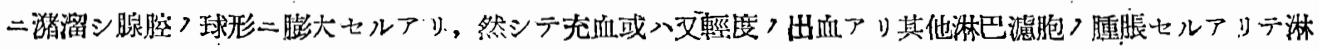

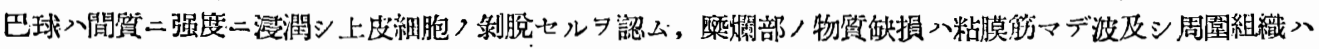

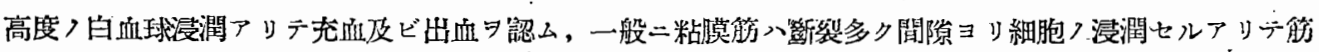

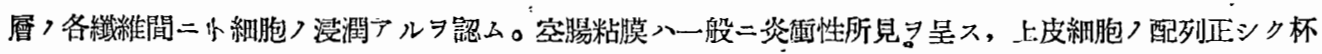

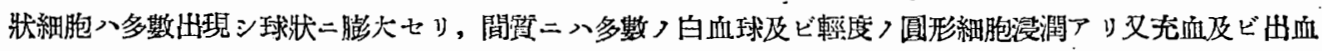

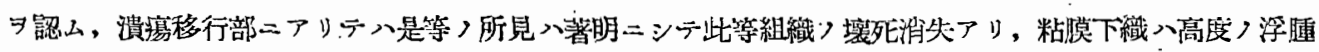

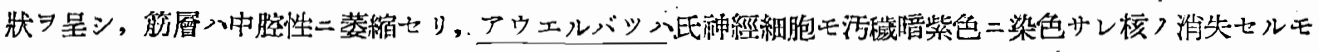

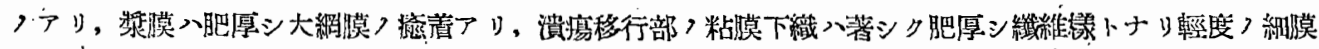

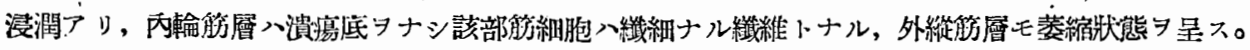

\section{第 4 館 術式 Eノ實驗成績}

Nr., 61 , ㅇ, 10.0kg.,

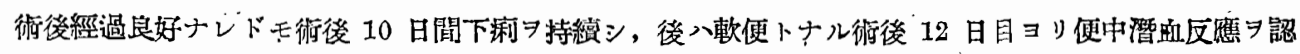

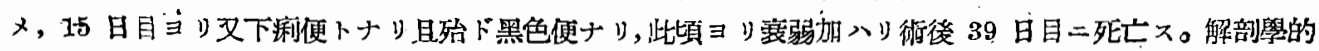

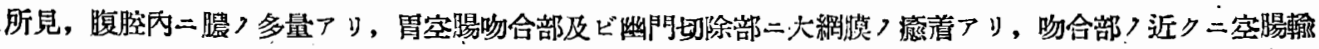

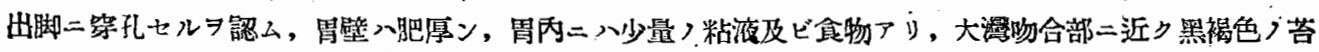

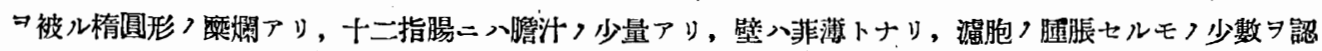




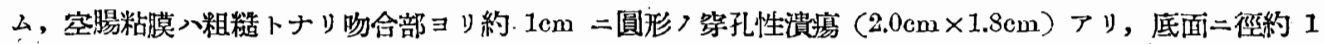
$\mathrm{cm}$, 圓形, 毞孔 $\exists$ 有シ, 腸間膜附着部二一致セズ, 份其近傍二小豆大, 潰瘍 1 箇ヨ認么, 空腸下部及ビ 呬腸二八赤黑色, 泥狀便アリ。組織學的所見, 胃粘膜二八殆ド細胞浸澖ナク主細胞及ビ壁細胞う配列正シ

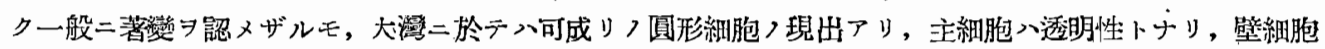

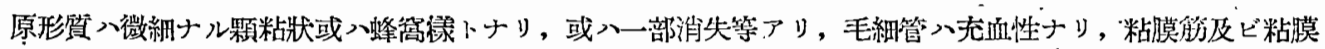

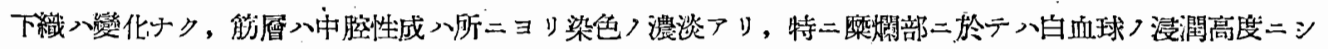

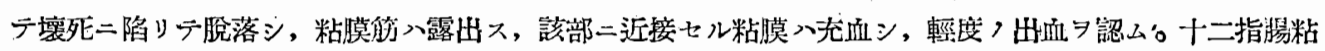

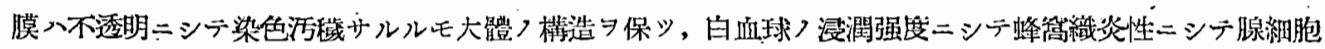

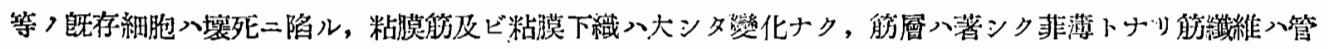
栐二萎縮七り。胃吻合部ヨリ上部空晹二於テモ白血球浸潤高度二シテ上皮細胞及腺細胞八壊死二陷ル。潰

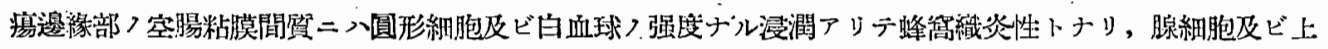

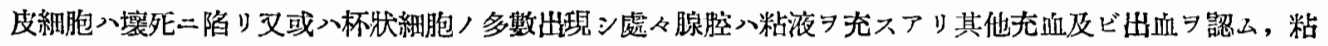

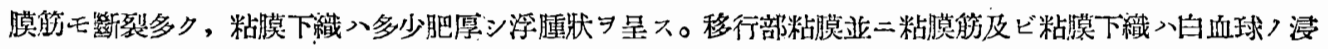

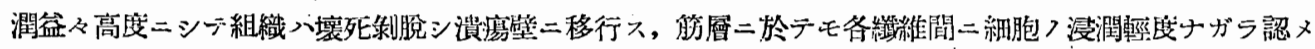

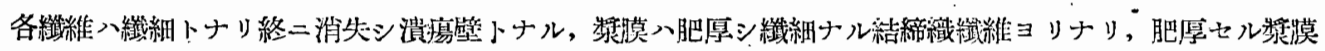

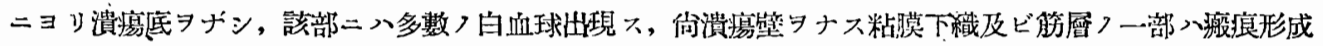

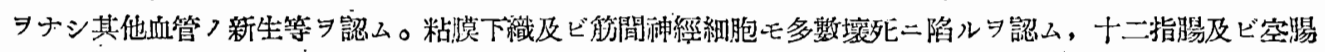
ニ於ヶル淋巴濾胞つ肥大セルモ高度ナラズ。

Nr. 62, 우, $7.5 \mathrm{~kg}$,

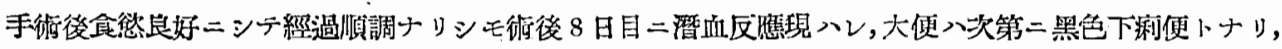

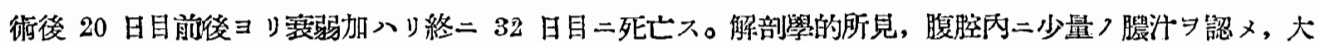

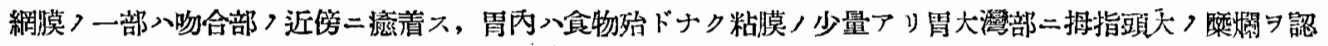

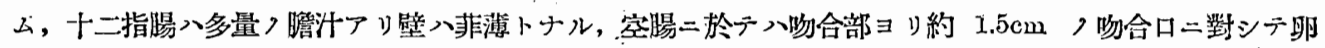

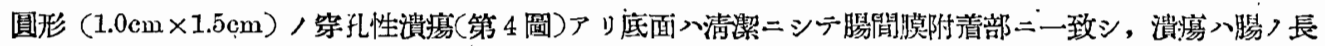

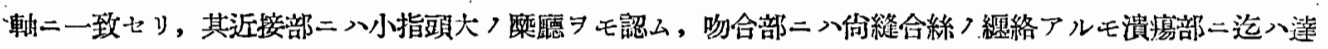
セズ, 空腸下部及ビ赹腸部二八處々出血斑 認么。組織學的所見, 胃粘膜八輕度つ圓形細胞及ビ淋巴細胞 フ浸潤アリ，基底部二於ヶル毛細血管ハ充血及ビ輕度つ出血习認么，是等つ變化ハ小灣部二於デハ殆ド認

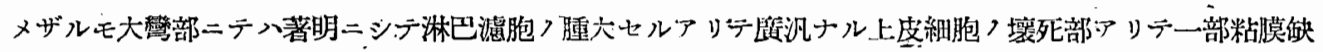

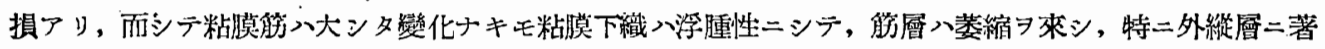

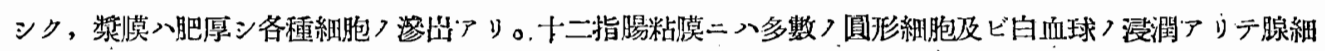

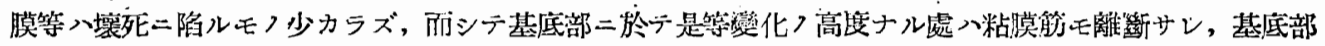

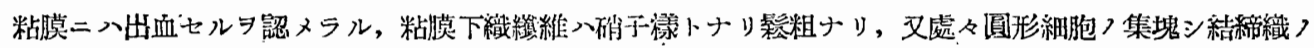

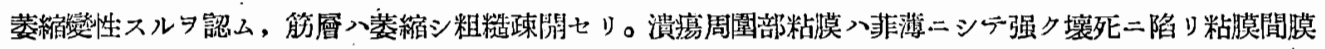
八腫脹シ高度ノ白血球, 圓形細胞フ浸潤及ビ出血等アリテ, 漸次粘膜層〉高サ.タ減ジ終二消失シテ潰瘍ニ

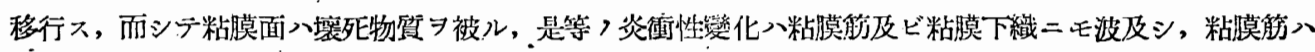
迦裂多ク蛇行狀トナリ潰瘍壁肉芽組織中二消失ス, 粘膜下織入結締織 フ增殖高度ニシテ密二肥厚シ一部二

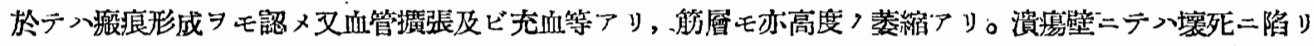

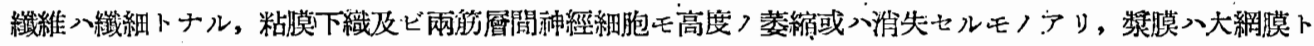

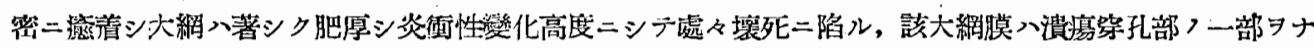

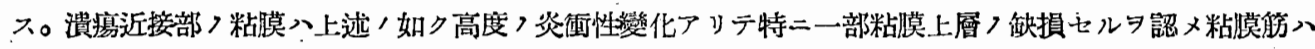
露出セリ, 其他十二指腸及ビ空腸二淋巴濾胞 フ腫脹アルモ著明ナルモフハ認メラレズ。

Nir., 65, ô, 9.5kg:, 


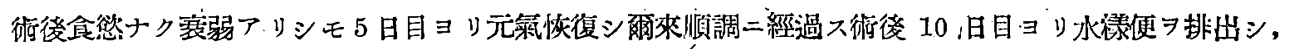

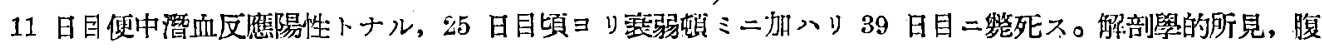

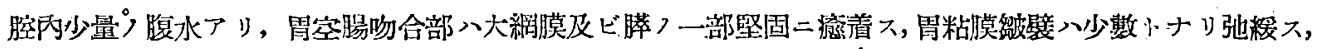

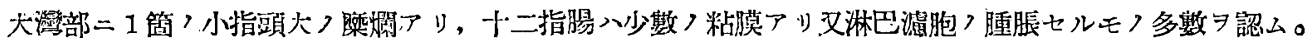

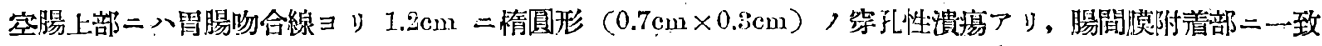

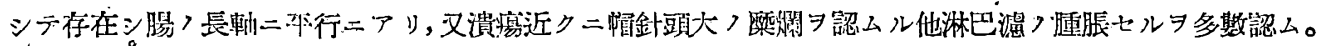

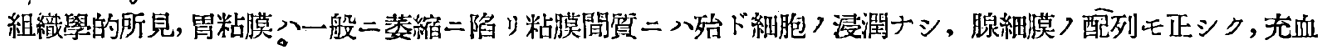

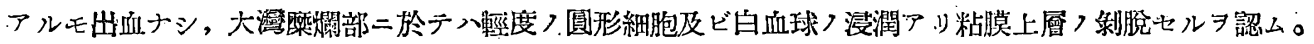

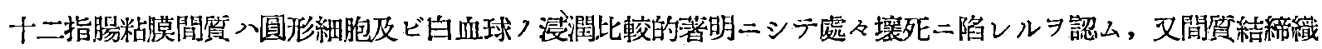

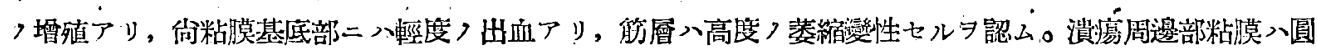

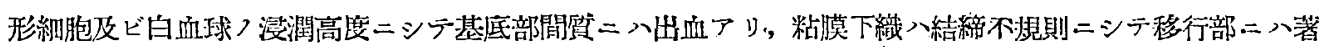

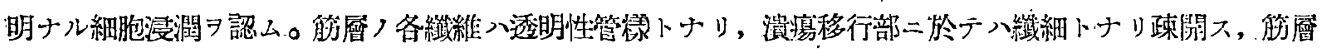

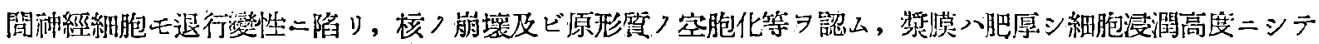

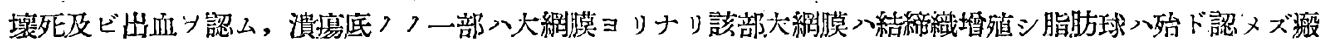

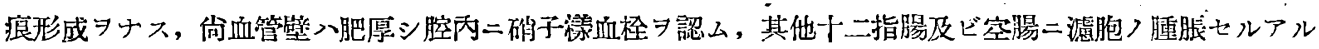
モ輕度ナリ。

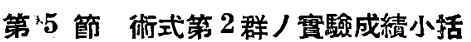

第 1 項 一般狀態及ビ剖检所見 (第 3 表參照)

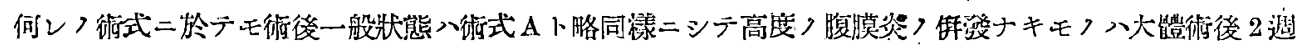

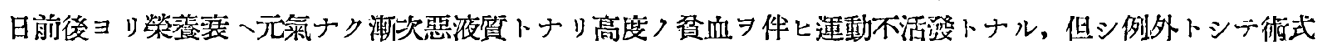

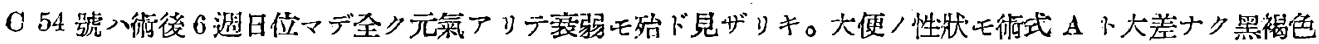

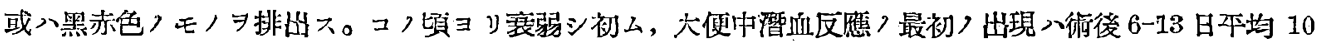
ナリ。

第 3 裴 随式第 2 群 八解剖所見總括

\begin{tabular}{|c|c|c|c|c|c|c|c|c|c|c|c|c|c|c|c|c|c|}
\hline \multirow{3}{*}{$\begin{array}{l}\text { 術 } \\
\text { 式 } \\
\text { 名 }\end{array}$} & \multirow{3}{*}{$\begin{array}{l}\text { 動 } \\
\text { 物 } \\
\text { 番 } \\
\text { 酦 }\end{array}$} & \multirow{3}{*}{$\begin{array}{c}\text { 術 } \\
\text { 前 } \\
\text { 體 } \\
\text { 重 } \\
(\mathrm{kg})\end{array}$} & \multirow{3}{*}{ 性 } & \multirow{3}{*}{$\begin{array}{l}\text { 生 } \\
\text { 你 } \\
\text { 日 } \\
\text { 數 }\end{array}$} & \multirow{3}{*}{ 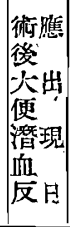 } & \multirow{3}{*}{$\begin{array}{l}\text { 鏠 } \\
子 \\
\text { 使 } \\
\text { 用 } \\
\text { 有 } \\
\text { 無 }\end{array}$} & \multicolumn{2}{|r|}{ 空 } & \multicolumn{2}{|c|}{ 溃、 } & \multicolumn{2}{|l|}{ 易 } & \multicolumn{2}{|l|}{ 糜 } & \multirow{2}{*}{\multicolumn{3}{|c|}{$\begin{array}{l}\text { 淋 } \\
\text { 巴滤 } \\
\text { 胞 }\end{array}$}} \\
\hline & & & & & & & \multirow{2}{*}{ 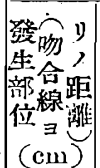 } & \multirow{2}{*}{$\begin{array}{c}\text { 大 } \\
\text { \#. } \\
\text { (cm) }\end{array}$} & \multirow{2}{*}{ - 形 } & \multirow{2}{*}{$\begin{array}{l}\text { 穿 } \\
\text { 孔 } \\
\text { 有 } \\
\text { 無 }\end{array}$} & \multirow{2}{*}{$\begin{array}{c}\text { 遥 } \\
\text { 緣 } \\
\text { 年 } \\
\text { 隆 } \\
\text { 起 }\end{array}$} & \multirow{2}{*}{ 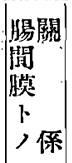 } & \multirow{2}{*}{$\begin{array}{l}\text { 發 } \\
\text { 生 } \\
\text { 部 } \\
\text { 位 }\end{array}$} & \multirow{2}{*}{$\begin{array}{l}\text { 火 } \\
\text { サ }\end{array}$} & & & \\
\hline & & & & & & & & & & & & & & & $\begin{array}{l}\text { 部 } \\
\text { 位 }\end{array}$ & 数 & $\begin{array}{l}\text { 火 } \\
\text { サ }\end{array}$ \\
\hline \multirow[b]{3}{*}{$\mathbf{B}$} & 47 & 7.2 & 우 & 33 & 10 & $a^{+}$ & $\begin{array}{l}2.0 \\
4.0 \\
\end{array}$ & $\begin{array}{r}1.0 \times 0.8 \\
0.3 \times 0.8\end{array}$ & $\begin{array}{l}\text { 睢形 } \\
\text { 圆形 }\end{array}$ & $\bar{t}$ & $\begin{array}{l}t \\
t\end{array}$ & - & & & 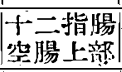 & 少 & $\begin{array}{l}\text { 大 } \\
\text { 中 }\end{array}$ \\
\hline & 48 & 8.5 & $\hat{\delta}$ & 32 & 6 & - & 0.5 & $|2.0 \times 3.0|$ & 卵圓班 & + & + & - & 空腸上部 & 小指㽬大次 & 十二指腸 & 多 & 穴 \\
\hline & 49 & 9.0 & $\hat{o}$ & 16 & 6 & - & $\begin{array}{l}3.0 \\
5.0\end{array}$ & $\begin{array}{l}1.0 \times 0.5 \\
0.3 \times 0.8\end{array}$ & 紡鍵形 & $\begin{array}{l}+ \\
=\end{array}$ & $\overline{+}$ & $\overline{-}$ & 大酸 & 示指喕火大 & 十二指腸 & 少 & 小 \\
\hline & 50 & 7.5 & 우 & 7 & & + & - & & & & & & 空腸上部 & 示指頍大 & 同 & 多 & 人 \\
\hline & 51 & 9.5 & $\hat{\delta}$ & 23 & 7 & + & 2.0 & $3.0 \times 0.8$ & 卵區形 & + & - & + & 画阿腸上部 & 捚指 & 同“上 & 多 & 犬 \\
\hline & 52 & $i 0.5$ & $\hat{0}$ & 29 & 10 & - & $\begin{array}{l}2.0 \\
2.0\end{array}$ & $\left|\begin{array}{l}1.0 \times 0.5 \\
0.3 \times 0.8\end{array}\right|$ & 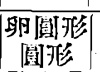 & - & $\begin{array}{l}+ \\
+\end{array}$ & - & & & 同 & 少 & 火 \\
\hline \multirow[t]{2}{*}{ C } & 54 & 11.0 & $\hat{\delta}$ & 52 & 13 & + & & & & . & & & 空腸，上部 & 小指頭大 & 同 上 & 少 & \\
\hline & 55 & 9.2 & & 46 & 10 & + & 0.3 & $0.8 \times 0.7 \mid$ & 圓形 & - & - & + & 空腸上部 & 小指頍大 & & & \\
\hline
\end{tabular}




\begin{tabular}{|c|c|c|c|c|c|c|c|c|c|c|c|c|c|c|c|c|c|c|}
\hline \multirow{3}{*}{$\dot{\mathrm{D}}$} & $\dot{5} 6$ & 9.0 & $\hat{o}$ & 33 & 8 & + & 1.5 & $2.0 \times 1.0$ & 曲玉狀 & + & + & - & $\begin{array}{l}\text { 火灣 } \\
\text { 空腸上部 }\end{array}$ & $\mid \begin{array}{l}\text { 示指頭大 } \\
\text { 小指頭大 }\end{array}$ & $\mid \begin{array}{l}1+ \\
3\end{array}$ & 上棌。 & 多 & 犬 \\
\hline & 58 & 10.2 & s. & 25 & 10 & - & $\begin{array}{l}1.0 \\
0.5\end{array}$ & $\begin{array}{l}0.8 \times 0.7 \\
0.3 \times 0.8\end{array}$ & 圆形 & + & + & 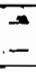 & & 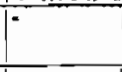 & 同 & 上 & 多 & $\begin{array}{l}\text { 大 } \\
\text { 中 }\end{array}$ \\
\hline & 59 & 10.5 & 우 & 46 & 13 & + & 3.0 & $0.4 \times 0.5$ & 圓形 & - & - & - & 十二指腸 & 示指頭大 & 同 & 上 & 多 & $\begin{array}{l}\text { 资 } \\
\text { 年 }\end{array}$ \\
\hline & 61 & 10.0 & 우 & 39 & 12 & + & 1.0 & $2.0 \times 1.8$ & 圓形 & + & - & - & $\begin{array}{l}\text { 穴彩 } \\
\text { 空腸上部 }\end{array}$ & 示指頭大 & 同 & 上 & 少 & $\begin{array}{l}\text { 中 } \\
\text { 中 }\end{array}$ \\
\hline & 62 & 7.5 & 우 & 32 & 8 & - & 1.5 & $1.0 \times 1.5$ & 卵圆形 & + & - & + & $\begin{array}{l}\text { 大灣 } \\
\text { 空腸上部 }\end{array}$ & 据指頭大 & 同 & t & 少 & 小 \\
\hline & 65 & 9.5 & $\$$ & 39 & 11 & - & 1.2 & $0.7 \times 0.8$ & 鲃圆形 & + & - & + & $\mid \begin{array}{l}\text { 矢灣 } \\
\text { 空腸_上珤 }\end{array}$ & 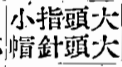 & 同 & 上 & 多 & 小 \\
\hline & 66 & 13.0 & 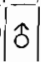 & 7 & & + & & & & & & & & & 同 & & 少 & ; \\
\hline
\end{tabular}

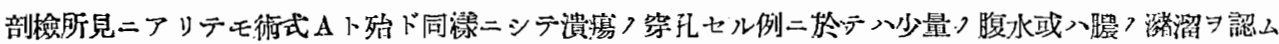

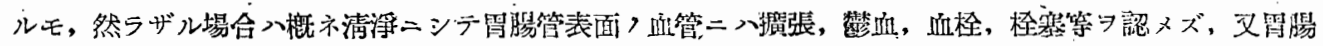

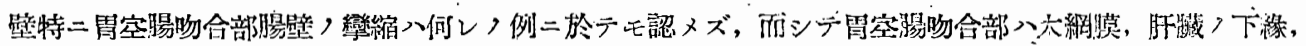

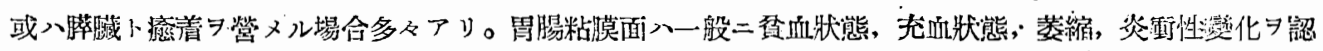

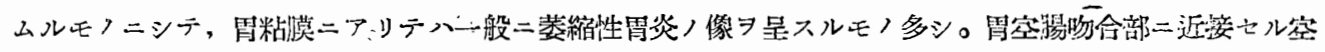

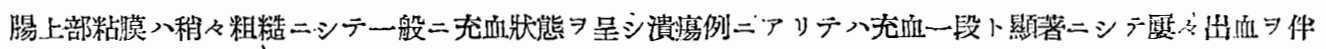

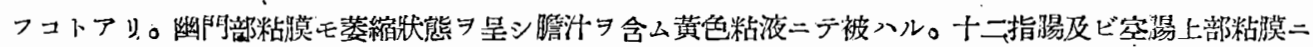

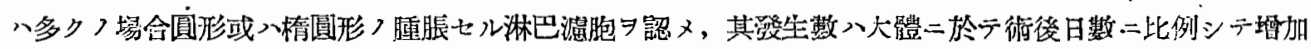
シ且又著明トナルモ必ズシモ否ラザル埸合モアリ。

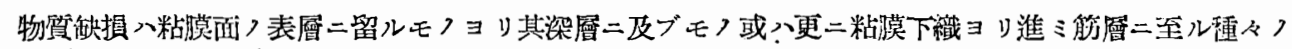

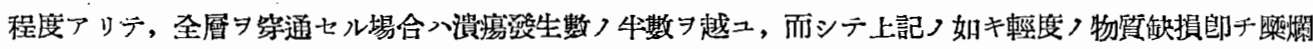
八大灣 5 , 幽門 1 , 十二指腸 1 , 空腸上部 9 筒ニシテ胃空腸吻合部二近接セル上部空腸粘膜二最モ頻發ス,

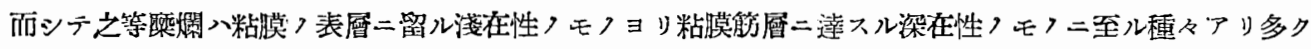
八不整形ニシテ底面八溷渴セル粘液或入凝血习附着セルコトアリ。

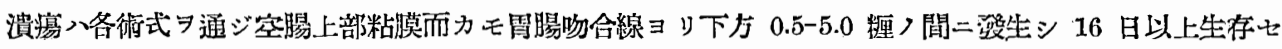

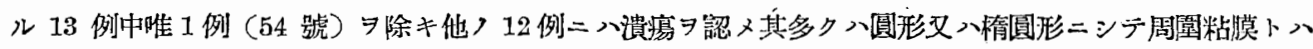

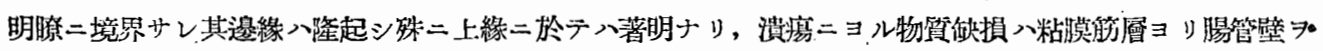

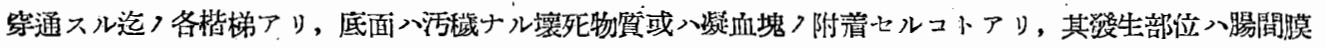

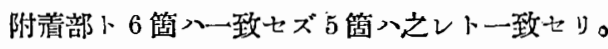

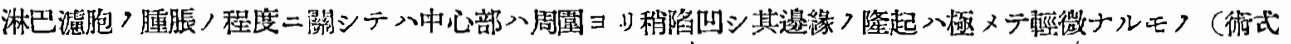
D. E), 稍高度ナルモ)(術式 B), 或空腸ニ於テ少數ナルモ高度ナルモノ(術式 C ) トアーリ。

\section{第 2 項 胃, 腸管/組織䁷的所見}

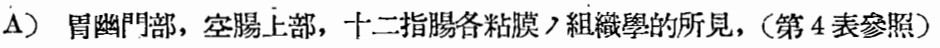

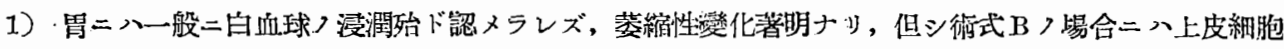

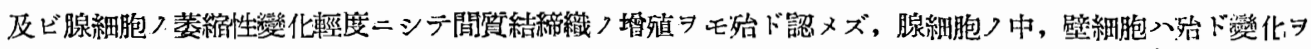

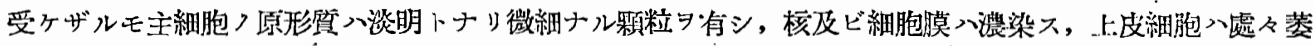

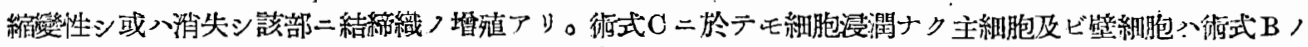

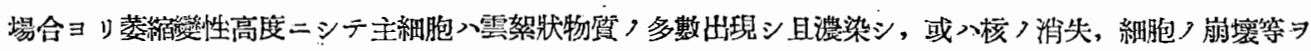
認么，壁細胞モ種々ナル形㑷ヨ示シ原形質中二多藪つ顆粒出現シ，核モ消失シ或八絴胞自體モ崩壞セルモ

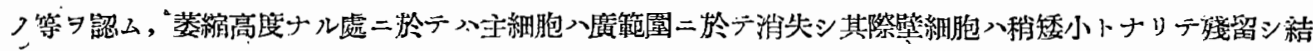

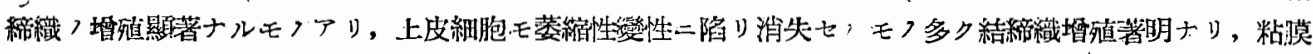
間質二於ヶル毛細血管入貧血性ナリ。術式Dニ於テモ細胞浸潤入認メラレズ輕度ノ充血アルフミ，主細胞 
及ビ壁細胞つ變化公前述つ如キ所見ナルモ其他壁細胞ノ空胞化习認メ'，空胞入胞體內二數筒出見セルモ，

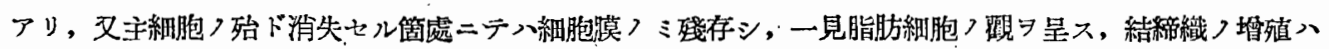
殆ド認メラレズ。術式 $\mathrm{E}$ /場合モ術式 $\mathrm{D}$ 二於ケルト同樣ニシテ, 細胞浸潤ナク腺細胞? 各種，萎縮狀態 認入，一般二血管八輕度，充血性

2）幽門部粘膜, 衐式 $\mathrm{B}$, 場合八一般二圓形細胞, 白血球, 淋巴細胞等ノ浸潤アリ, 又淋巴細胞八集族 的二粘膜基底部二存スルモ濾胞中心ヨ認メズ, 長期生存セルモ；八細胞浸潤殆ド認メラレズ, 一般二粘獏 間啠入結締織增殖著明ニアリ，上皮細胞入細胞浸潤高度ナル部二八偯死二陷り不規則ニ配列シ脫落セルア

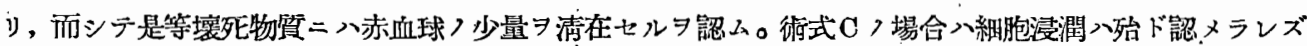

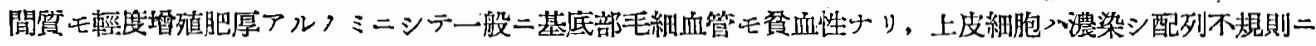

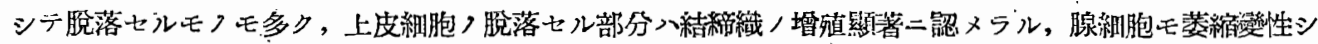

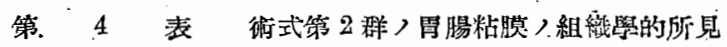

\begin{tabular}{|c|c|c|c|c|c|c|c|c|c|c|c|c|c|c|c|}
\hline \multirow[t]{2}{*}{ 術 } & \multirow{2}{*}{$\begin{array}{l}\text { 動 } \\
\text { 物 } \\
\text { 番 } \\
\text { 號 }\end{array}$} & \multirow{2}{*}{$\begin{array}{l}\text { 微 } \\
\text { 後 } \\
\text { 告 } \\
\text { 存 } \\
\text { 藪 }\end{array}$} & \multicolumn{2}{|c|}{ 架 } & & \multicolumn{2}{|c|}{ 部 } & \multicolumn{4}{|c|}{ 胃 幽 門 部 } & \multicolumn{4}{|c|}{ 十二 指 腸 } \\
\hline & & & $\begin{array}{l}\text { 細 } \\
\text { 胞 } \\
\text { 䍜 }\end{array}$ & 充 & 出 & 糜 & $\begin{array}{l}\text { 潰 } \\
\text { 演 }\end{array}$ & $\begin{array}{l}\text { 細 } \\
\text { 胞 } \\
\text { 浸 } \\
\text { 潤 }\end{array}$ & $\begin{array}{l}\text { 充 } \\
\text { 血 }\end{array}$ & 出 & $\begin{array}{l}\text { 糜 } \\
\text { 瓓 }\end{array}$ & $\begin{array}{l}\text { 細. } \\
\text { 胞 } \\
\text { 浸 } \\
\text { 潤 }\end{array}$ & 㳘 & $\begin{array}{l}\text { 出 } \\
\text { 血 }\end{array}$ & $\begin{array}{c}\text { 糜 } \\
\text { 閵 }\end{array}$ \\
\hline B & $\begin{array}{l}47 \\
43 \\
49 \\
50 \\
51\end{array}$ & $\begin{array}{r}33 \\
32 \\
16 \\
7 \\
23\end{array}$ & $\begin{array}{l}H \\
H \\
H \\
H \\
H \\
H\end{array}$ & $\begin{array}{l}+ \\
+ \\
H \\
+H\end{array}$ & $\begin{array}{l}+ \\
+ \\
+ \\
+t \\
+\end{array}$ & $\begin{array}{l}+ \\
+ \\
+ \\
+\end{array}$ & $\begin{array}{l}+ \\
+ \\
+ \\
+\end{array}$ & $\frac{+}{+}+$ & $\begin{array}{l}\overline{-} \\
\overline{+} \\
+\end{array}$ & $\begin{array}{l}= \\
\overline{-} \\
+ \\
+\end{array}$ & $\begin{array}{l}- \\
\overline{-} \\
\overline{+}\end{array}$ & $\frac{+}{\pi}$ & $\frac{\bar{t}}{\bar{t}}$ & $\begin{array}{l}- \\
- \\
- \\
-\end{array}$ & $\begin{array}{l}\bar{z} \\
\bar{z}\end{array}$ \\
\hline $\mathbf{C}$ & $\begin{array}{l}52 \\
54 \\
55\end{array}$ & $\begin{array}{l}29 \\
52 \\
46\end{array}$ & $\begin{array}{l}\text { 刑 } \\
\text { 开 }\end{array}$ & $\begin{array}{l}H \\
+ \\
+1\end{array}$ & $\begin{array}{l}+ \\
+ \\
+\end{array}$ & $\begin{array}{l}- \\
+ \\
+\end{array}$ & + & $\begin{array}{l}\dot{-} \\
+ \\
+\end{array}$ & $\bar{t}$ & $\bar{z}$ & $\begin{array}{l}= \\
=\end{array}$ & $\begin{array}{l}+1 \\
+1 \\
+t\end{array}$ & $\begin{array}{l}\bar{t} \\
+\end{array}$ & $\begin{array}{l}\bar{z} \\
\overline{-}\end{array}$ & $=$ \\
\hline $\mathrm{D}$ & $\begin{array}{l}56 \\
58 \\
59\end{array}$ & $\begin{array}{r}33 \\
25 \\
46\end{array}$ & $\begin{array}{l}+H \\
\text { H } \\
\text { H }\end{array}$ & $\begin{array}{l}\text { H } \\
+1 \\
+1\end{array}$ & $\begin{array}{l}+ \\
+ \\
+\end{array}$ & $\stackrel{+}{-}$ & $\begin{array}{l}+ \\
+ \\
+\end{array}$ & $\frac{t}{t}$ & $\bar{z}$ & $\bar{z}$ & $\begin{array}{l}+ \\
- \\
-\end{array}$ & $\begin{array}{c}+ \\
+ \\
+\end{array}$ & $\begin{array}{c}\overline{+} \\
+t+\end{array}$ & $\overline{-}$ & $\bar{z}$ \\
\hline $\mathbf{E}$ & $\begin{array}{l}61 \\
62 \\
65 \\
66\end{array}$ & $\begin{array}{r}39 \\
32 \\
39 \\
7\end{array}$ & 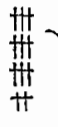 & $\begin{array}{l}+ \\
+ \\
+ \\
+\end{array}$ & $\begin{array}{l}+ \\
+ \\
+ \\
-\end{array}$ & $\begin{array}{l}+ \\
+ \\
+ \\
-\end{array}$ & $\begin{array}{l}+ \\
+ \\
+ \\
+\end{array}$ & $\begin{array}{l}t+ \\
+t \\
+ \\
+\end{array}$ & $\begin{array}{l}+ \\
+ \\
+ \\
-\end{array}$ & $\begin{array}{l}\overline{+} \\
-\end{array}$ & $\begin{array}{l}+ \\
+ \\
+ \\
-\end{array}$ & $\begin{array}{l}\text { W } \\
+ \\
+ \\
+\end{array}$ & $\frac{H}{+}+$ & $\frac{\pi}{+}$ & $\begin{array}{l}\bar{z} \\
\bar{z}\end{array}$ \\
\hline
\end{tabular}

(开 著明, 析 中等洨 + 輕落)

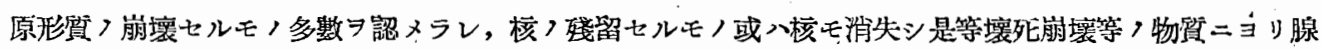

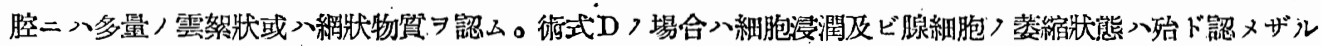

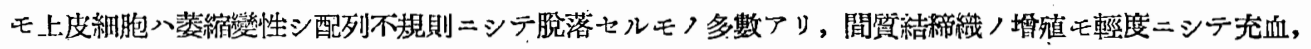
出血八全ク認メラレズ。

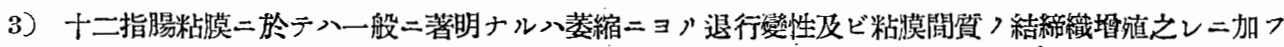

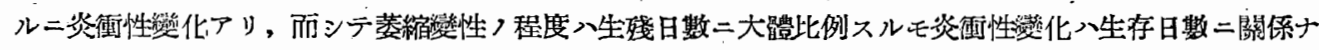

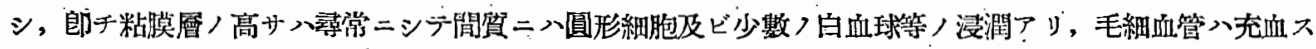

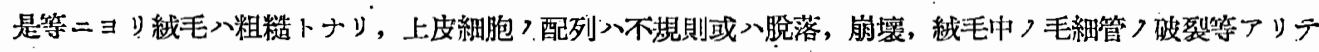

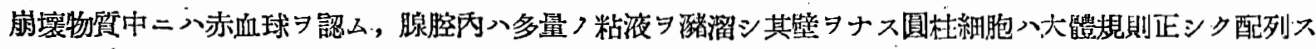

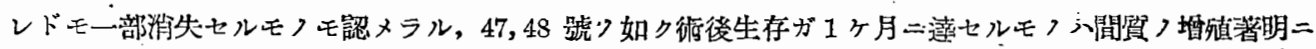

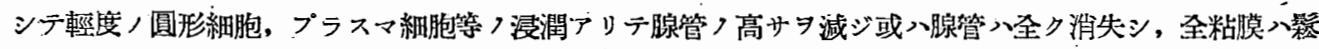
租ナル結締織層トシテ認メラル(第6 圖)。其他充血及ビ出血八殆ド認メラ、レズ，然レ共又術式D 59 號及 ビ術式 E 61 號入生存日數 40 日前後ニ及ベルモ而カモ炎㣫高度ナルニ關ラズ麻攔：ヨ認メタリ。. 


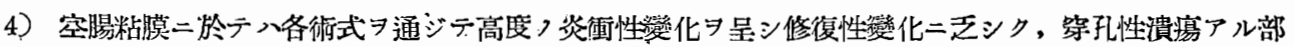

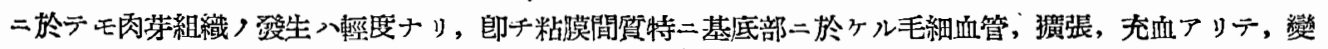

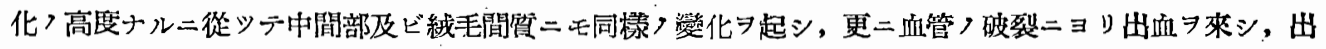
血入粘膜上層部二高度ニシテ基底部二モ認メラルルモ輕度ナリ，而シデ出血二本行シテ間質二八細胞ノ浸

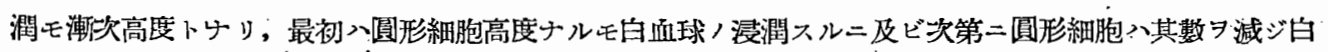

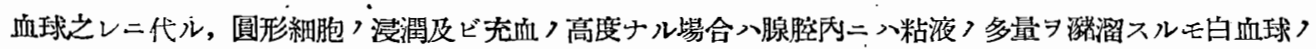
核潤スル時期トナレバ充血, 出血ニョル腺細胞及ビ上皮細胞, 浮腫 7 來シ, 初丈上皮細胞入配列不規則卜 ナリ壤死脱落、，次二腺細胞モ同浗/變化、呈シ腺腔內一脫落或入消失スルニ至り加之, 新シキ出血等二

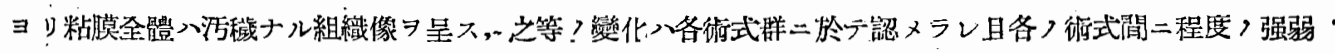
ヨ決定シ難シ。術式二 B.C 於ヶル十二指腸二連ル空腸粘膜入白血球つ浸潤アルモ極ク輕度ニシテ單核圓

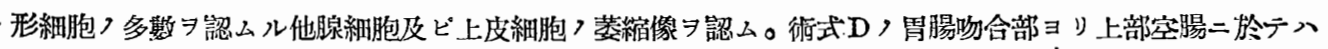
圆形細胞及ビ少數つ白血球ノ浸潤アリテ加答兒性炎, 所見ヨ呈シ充血アルモ出血等入認メラレズ, 胃吻合

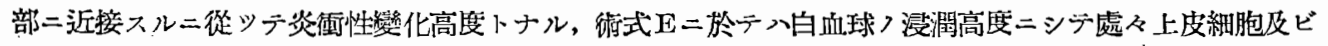
腺細胞八壞死二陷り其他充血, 出血, 浮腫等 7 認么。

B）糜爛，潰痗及ビ淋巴濾胞周園部二於ヶル組織學的所見

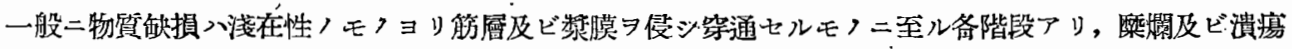

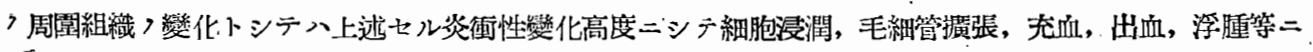

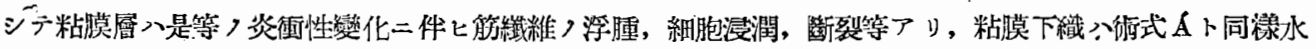

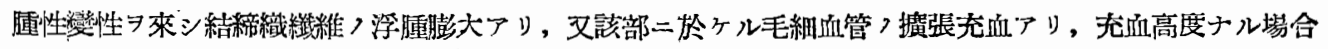

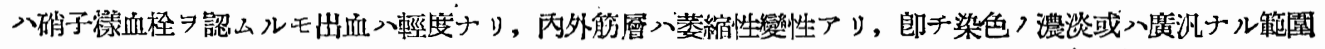

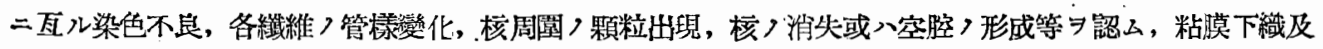

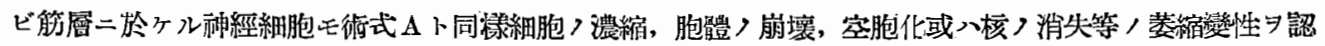

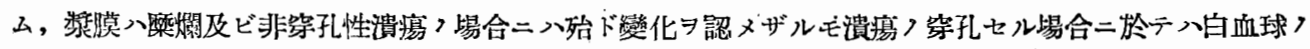

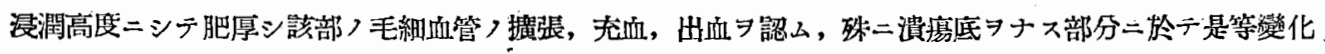

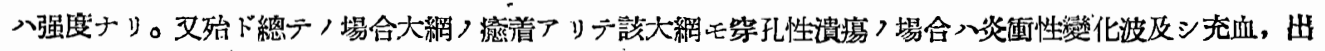

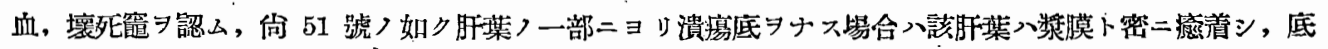
ヨナス肝組織入監沉ナル壞死二陷り周園二八高度ノ充血アルラ認ム。

\section{第 5 章術式第 3 群}

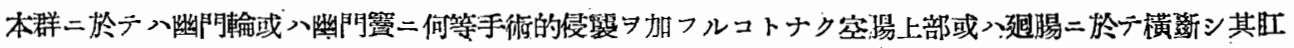

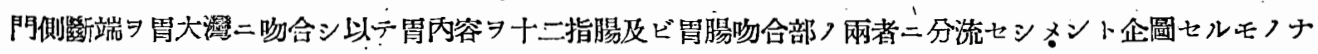
リ。吅于 (1) 空腸上部ニテ橫路シ, 其䢸門側

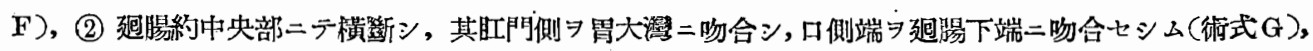
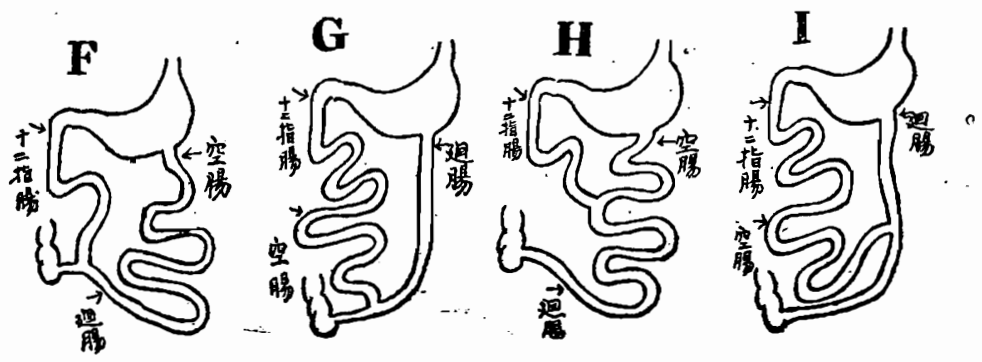

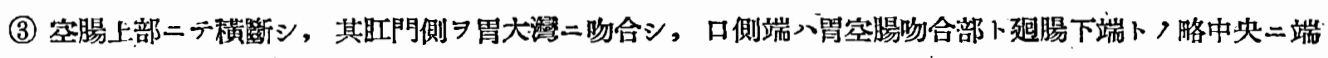




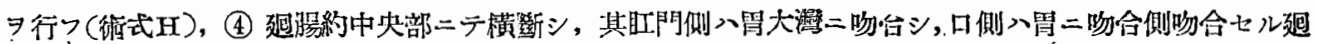

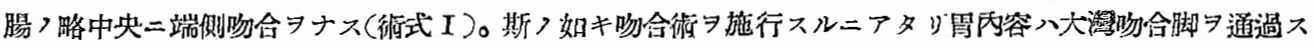

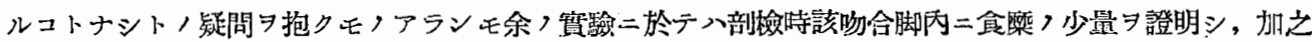

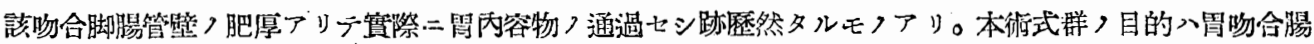

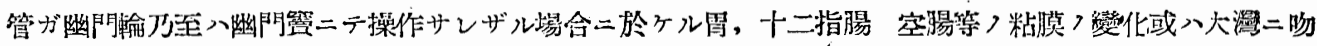

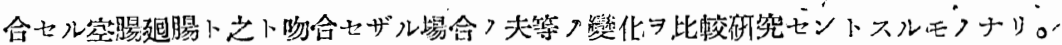

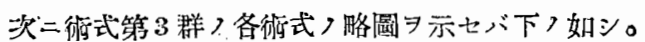

Nir., 68, ㅇ, 11.0kg.,

\section{第 1 節 術式 $\mathbf{F}$ /實鞈成綪}

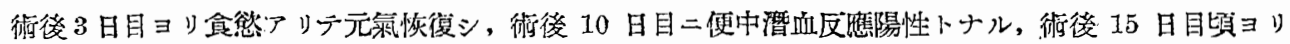

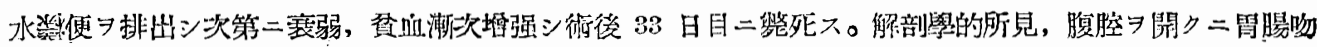

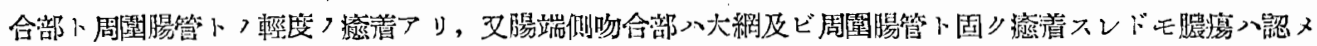

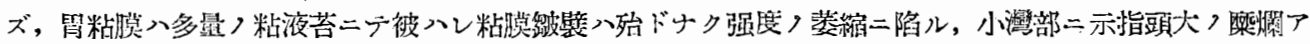

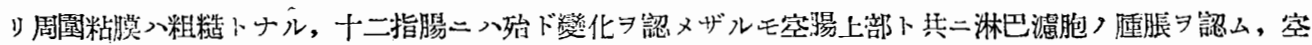

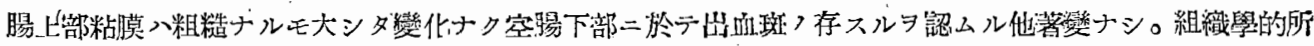

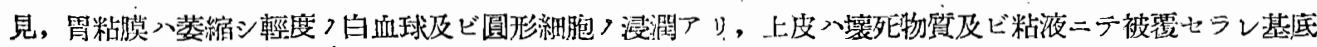

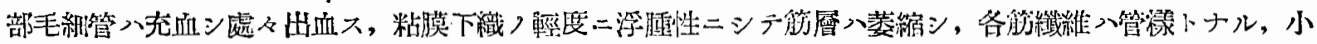

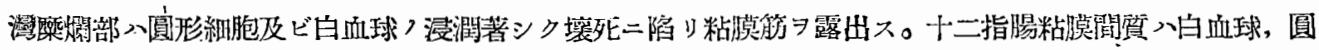

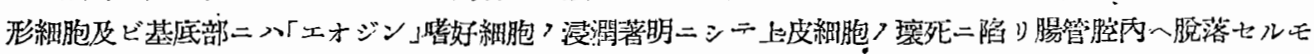

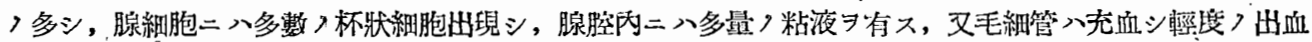

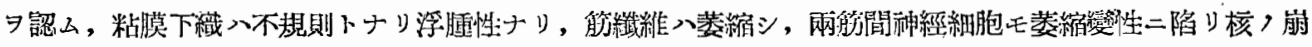
壤及ビ消失セルヨ認ム。空腸上部二於ラ八白血球, 圓形細胞及ピ「エオジン」嘴好細胞等，浸潤アリ，杯狀

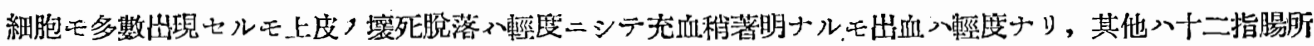
見卜大美ナシ。空腸下部二於デ上記所見，他充血及ビ出血著明ニシデ筋層モ强度，萎縮二陷ル，十二指

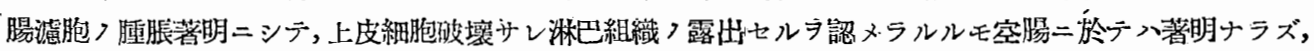
其他空腸ノ上皮層間質二結締織增殖

Nr., 70, $\hat{0}, 7.8 \mathrm{~kg}$.,

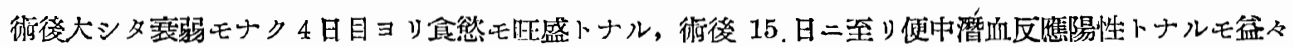

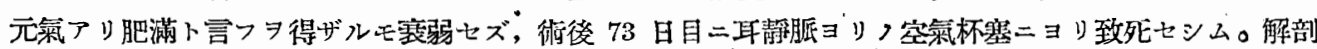

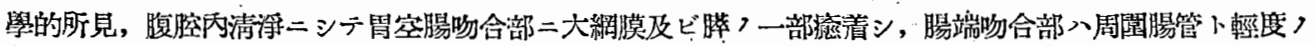

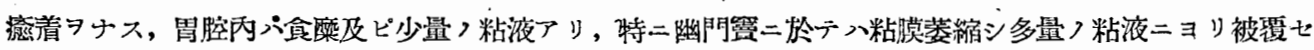

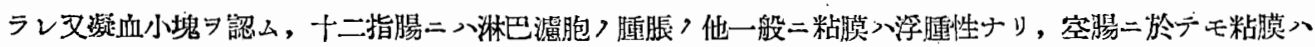

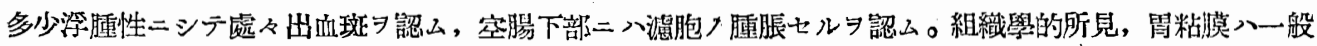

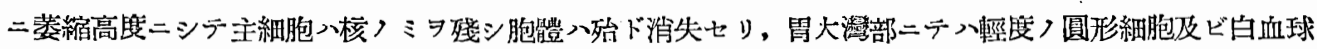
，浸潤アリ，其基底毛細管入充血アルモ出血入認メラレズ, 粘膜下織入浮腫性トナ.リ結䅭織ハ不規則ナリ，

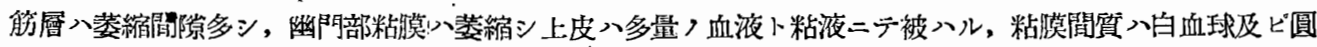
形細胞〉浸潤アリ，他方結締織モ增殖ス，毛細管入充血及ピ出血ヨ認ム，又處々淋巴濾胞〉腫脤アリテ上

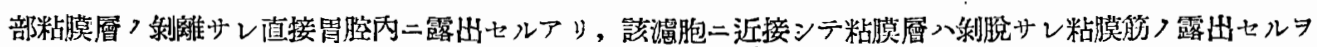

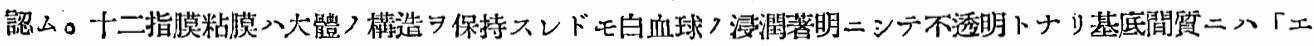

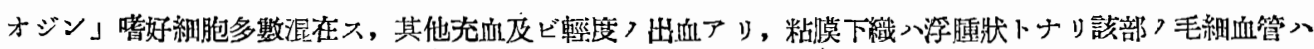

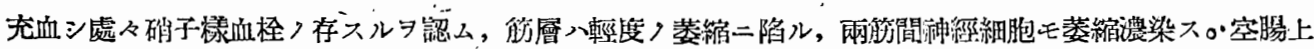

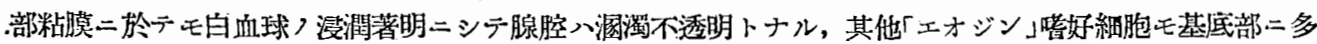




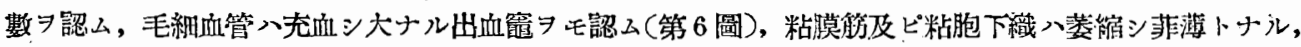

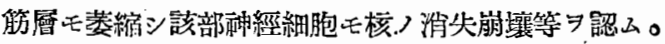

Nr., 71, 合, $8.0 \mathrm{~kg}$.,

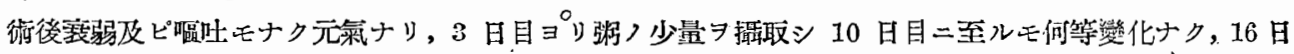
目二便中潛血反應陽性トナル,. 然レドモ大シタ衰弱モナク經過シ 43 日目三空类栓塞ニテ致死セシム, 其

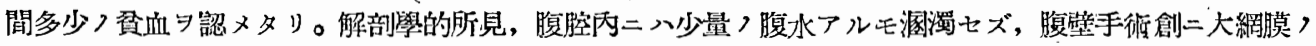

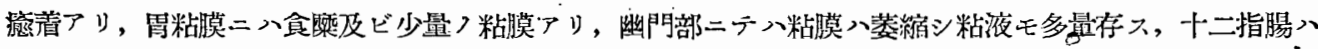

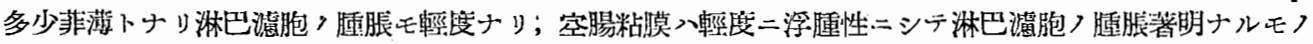

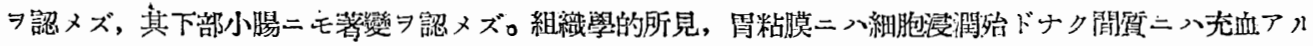

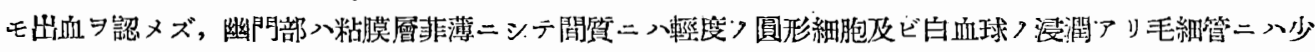

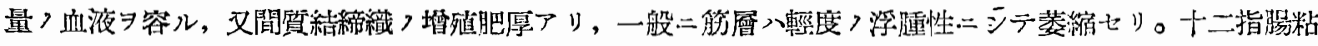

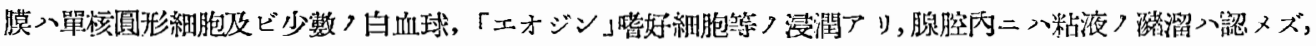

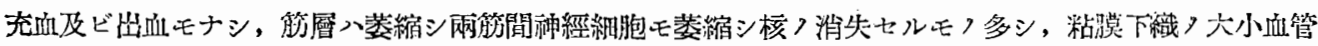
八充血恺ナリ，十二指腸二速ル空晹粘獏二於デモ單核圓形細胞及ビ其基低部ニハ「エオジン」嘴好細胞つ漫

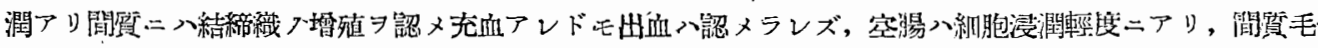

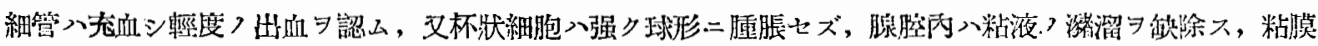

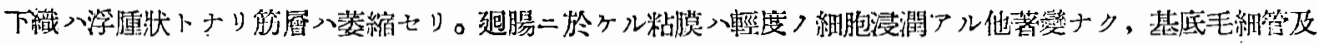

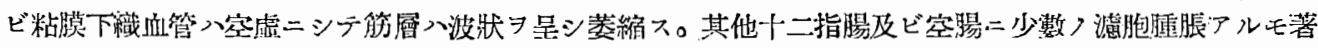
明ナラズ。

Nir., 72, $\hat{\delta}, 6.5 \mathrm{~kg}$,

\section{第 2 節 術式 $\mathbf{G}$ /顮驗成績}

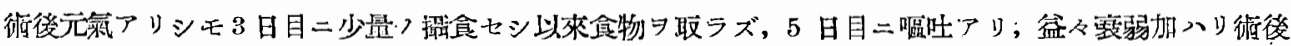

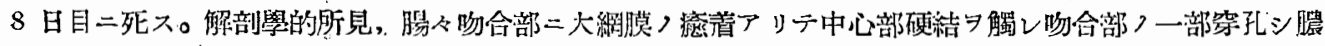

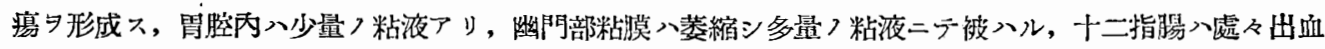

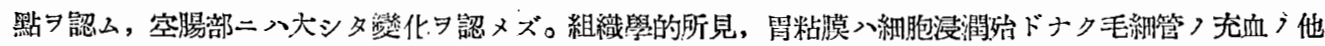

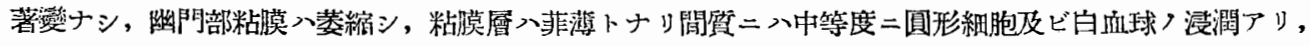

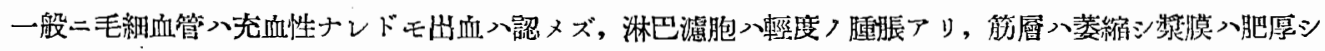

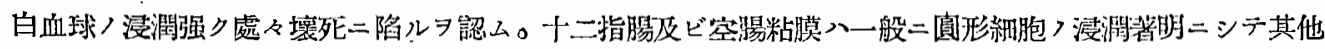

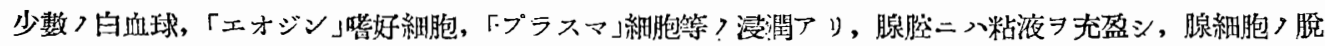

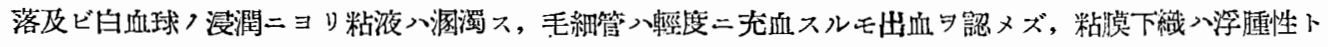

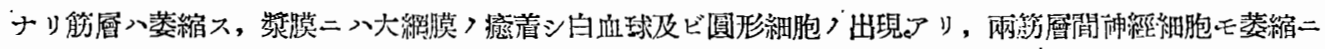

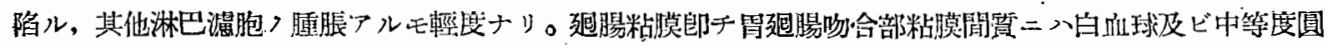

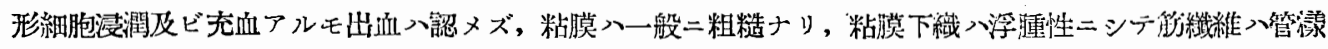
トナリ蒌縮ス。

Nr., 74, 今, 7.0kg., .

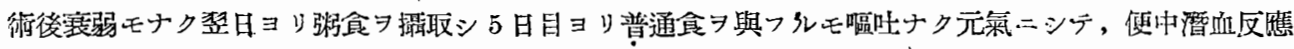

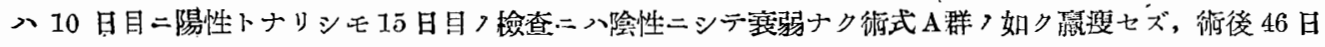

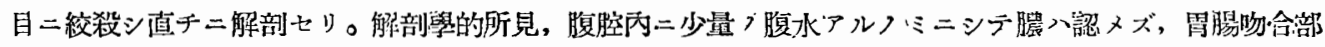

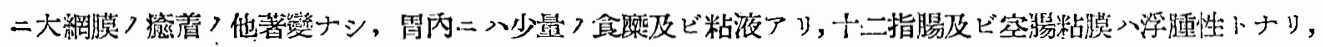

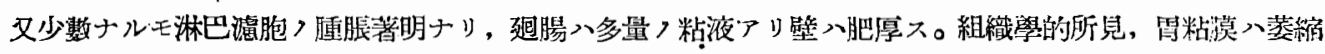

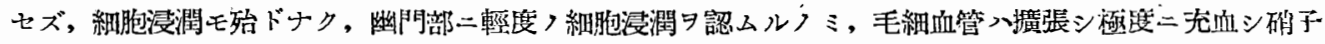

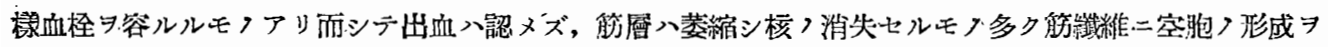


認么。十二指腸粘膜入肥愿シ閒貿二白血球及ビ圓形細胞つ浸潤著明れシテー般ニ不透明トナリ污染サレ處

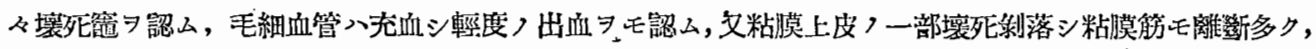

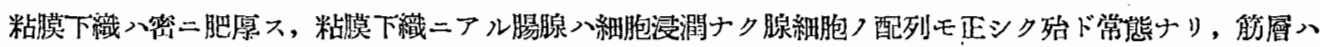

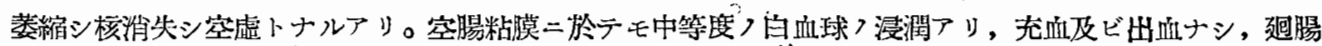

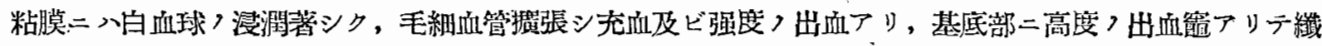

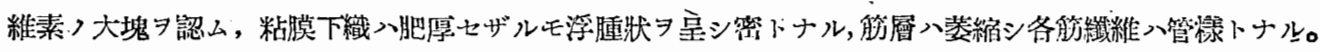
Nr. 75, 占, 9.2kg.,

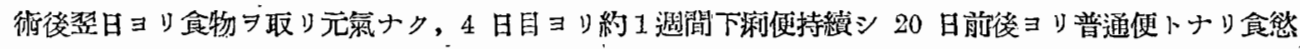

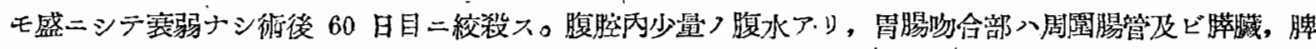

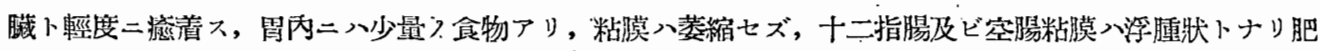

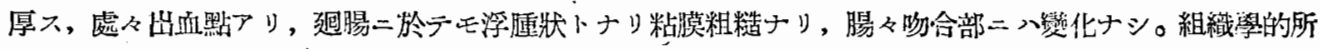

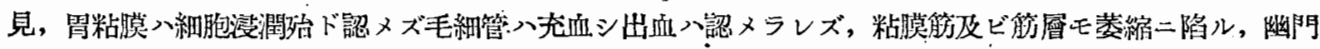

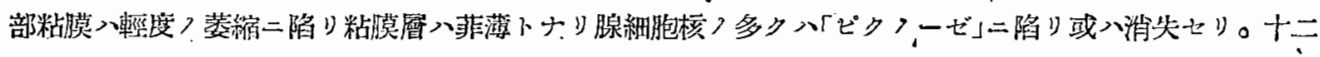

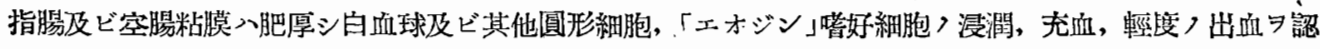

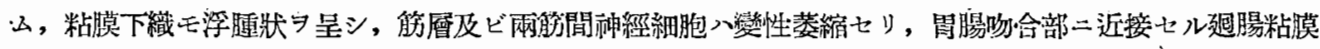

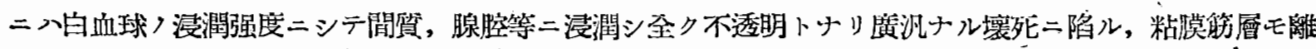

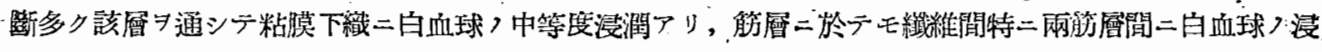
潤著明ニシデ談部神經細胞モ變性セリ，漿膜入輕度〉肥厚及ビ細胞浸閵アリ，十二指腸二於ヶル淋巴濾胞

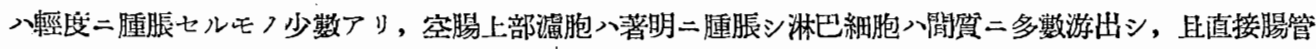
內二モ游出ス。

Nr., 76,,$+ 7.0 \mathrm{~kg} . ;$

\section{第 3 笁 術式 $\mathbf{H}$ /實驗成綪}

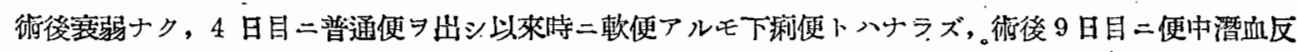

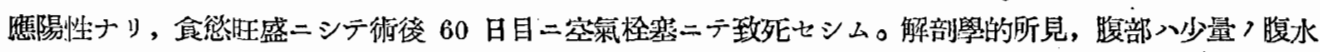

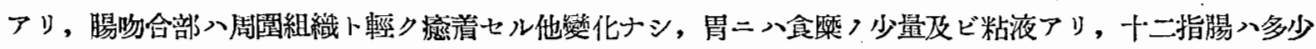

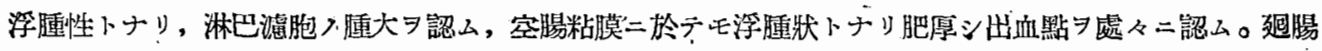

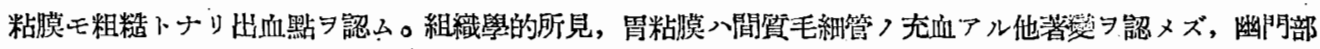

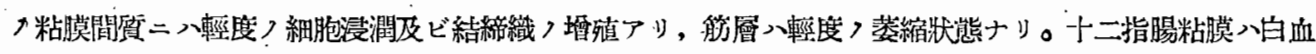

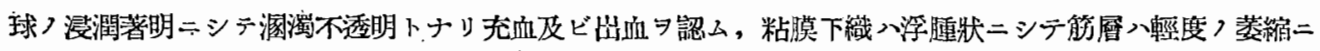

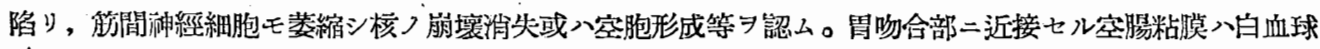

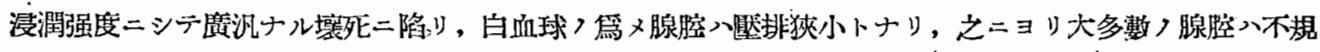
則トナリ或入消失シ基底部〉ミ殘留ス, 其部分二八充血强ク出血モ輕度二認么。粘膜下織入浮腫状

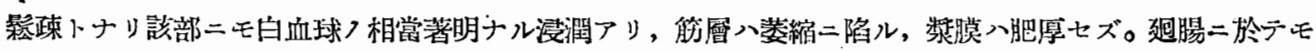

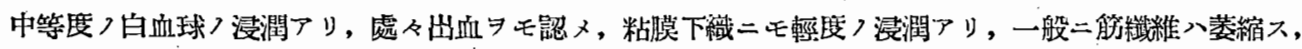

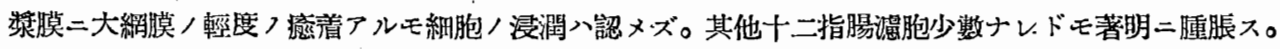

Nr., 78, 우, $8.7 \mathrm{~kg}$,

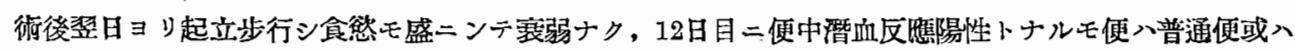
時二軟便ナリ, 術後 70 日目ニ「ストリヒニン」皮下注射ニテ致死セシム。解剖學的所見, 腹腔內清橴ニシ

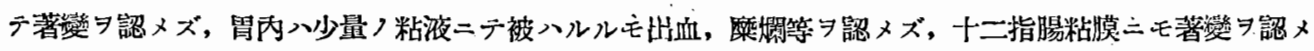

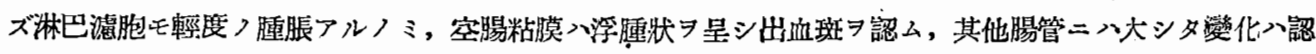

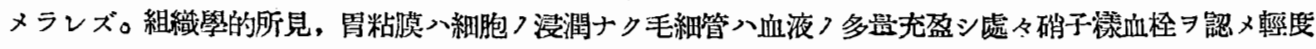

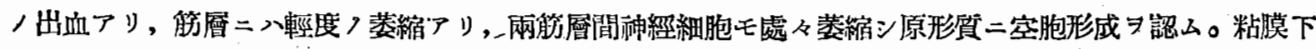


織二八細胞浸潤ナク浮腫狀ヨ呈ス。空腸粘膜二モ著明ナル白血球等つ浸潤アリデ粘膜層溷濁不透明トナリ

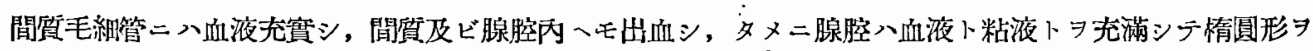

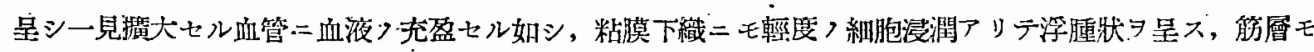
輕度, 菱縮状態习呈ス。

Nr., $-97, \hat{\delta}, 7.5 \mathrm{~kg}$,

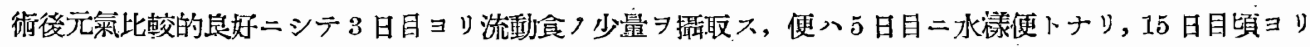

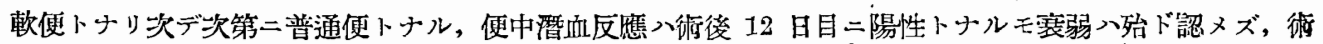
後 50 日目ニ「ストリヒニン」皮下注射ニヨリ致死セシム。解剖學的所見, 腹腔內声浮ニシテ腹水タ認メズ;

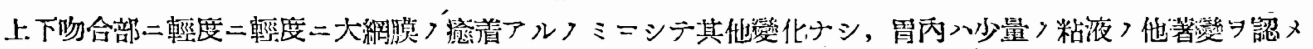

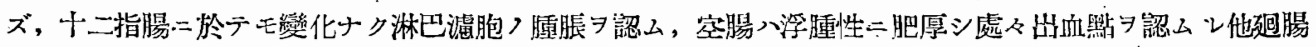

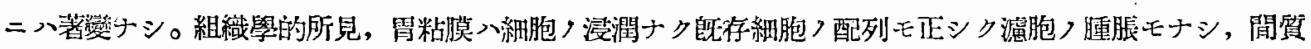

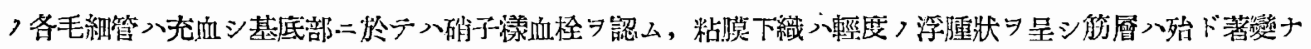

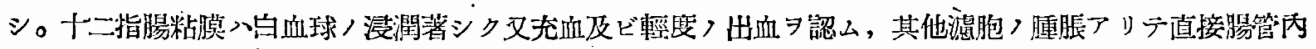

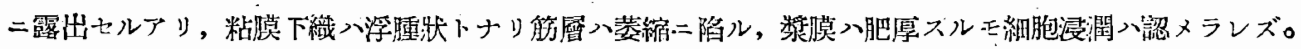

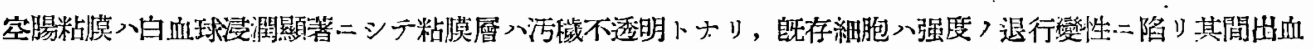

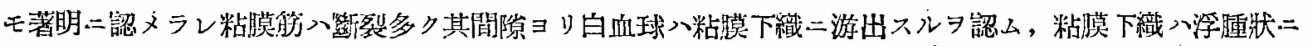

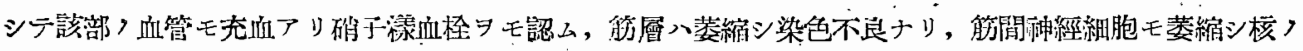
消失セルモノ多數习認ム。迴腸二於テモ中等度白血球ノ浸潤アリ，充血アルモ出血ハ認メラレズ。

\section{第 4 節”術式 I ノ霣驗成綪}

Nr., 82, 命, 8.9kg.,

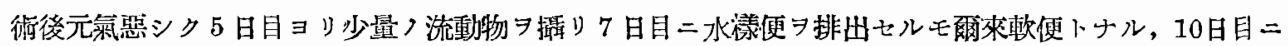

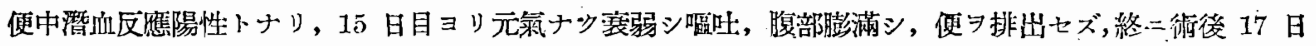

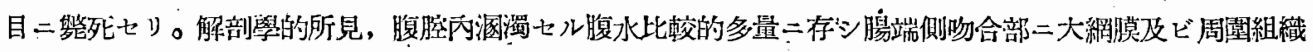

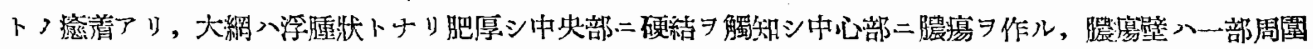
腸管:ョリ形成セラル, 胃入膨满シ粘液ノ多量アリデ苔ヨ被ルアリ, 十二指腸, 空腸入菲薄トナリ, 粘膜

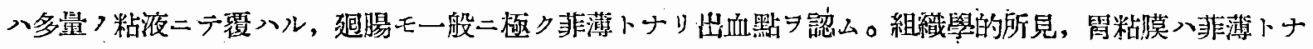
リ中等度:白血球，浸潤アリ，腺腔二八多量つ粘液アリ，充血アルモ出血入認メズ, 粘膜下織入浮隀狀卜

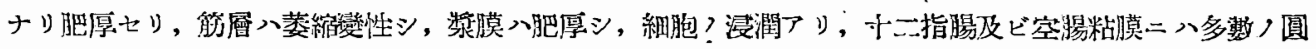

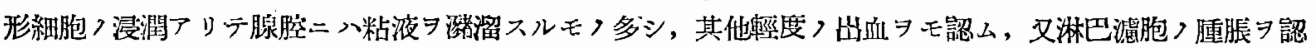

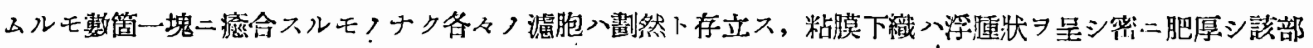

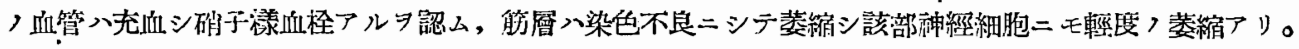

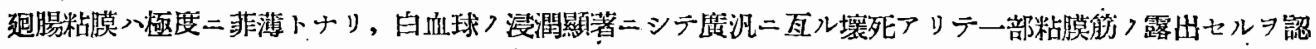

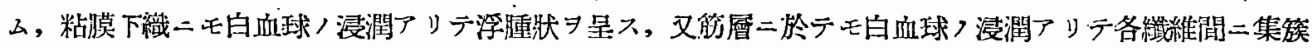

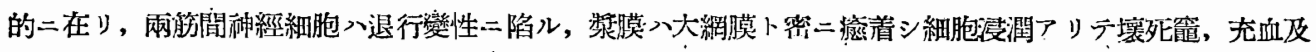
ビ出血等 $习$ 認么。

$\mathrm{Nr} ., 83$, 官, 8.0kg.,

術後元氣アリ害弱ナク, 柆日ヨリ流動食ヨ取り, 4 日目ヨリ㜞便ヨ排出シテ以來水汤健ヨ排出セズ, 便

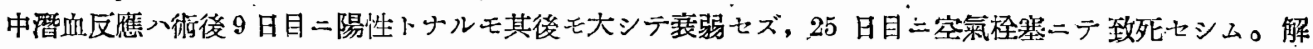

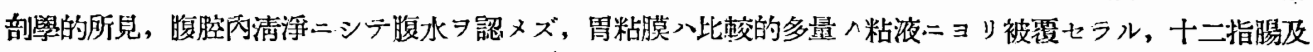

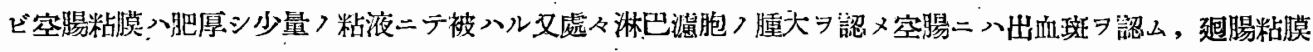

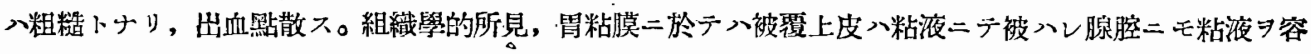

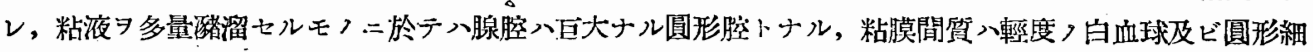


胞フ浸㵎及ビ充血アリデ加答兒性所見

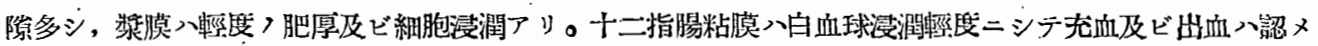

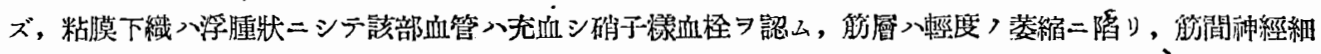

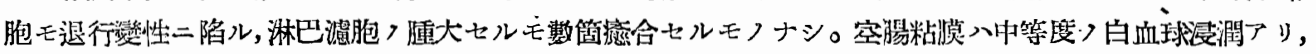

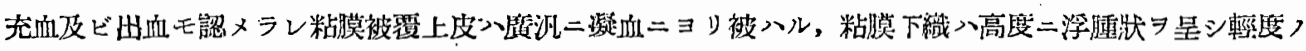

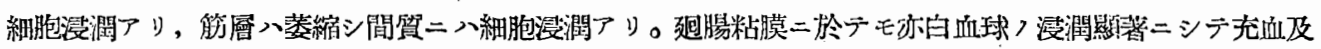

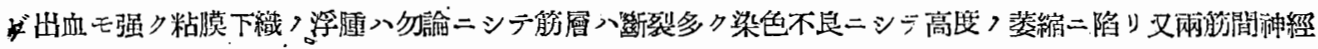
細胞入强度, 萎縮變性シ，漿膜、入多少肥厚セり。

Nr., $85, \%, 7.0 \mathrm{~kg}$,

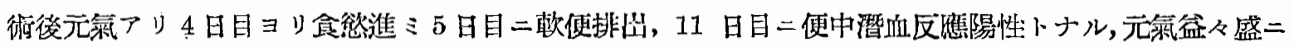

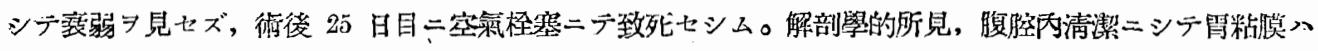

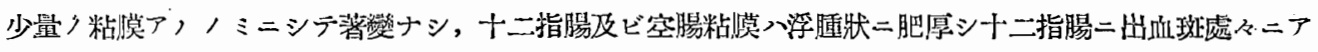

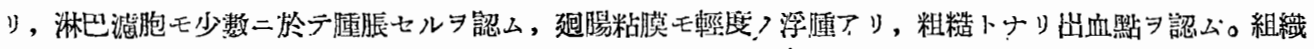

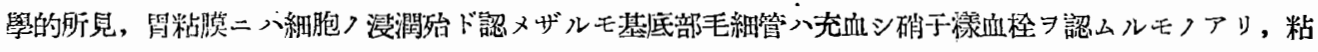

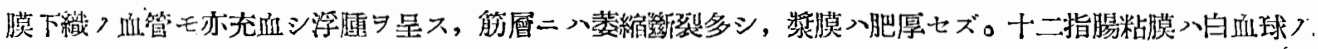

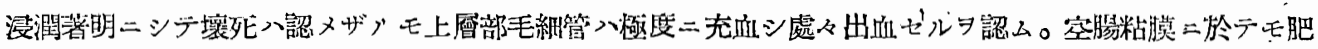

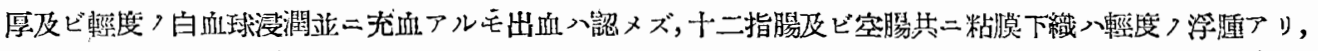

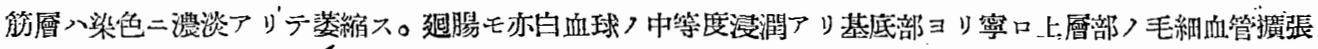

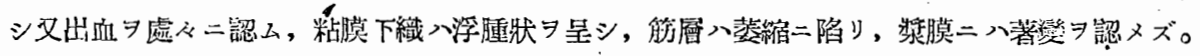

\section{第 5 節，術式第 3 群ノ望驗成綪小焒}

\section{第 1 項 一般狀態及ビ副檢所見 (第 5 表參照)}

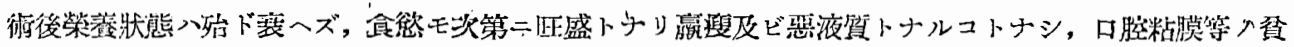

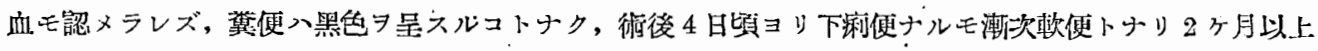

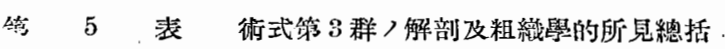

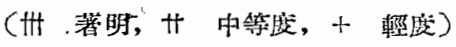

\begin{tabular}{|c|c|c|c|c|c|c|c|c|c|c|c|c|c|c|c|c|c|c|c|c|}
\hline 䢖 & 動 & 微 & 憐 & 生 & $\begin{array}{l}\text { 術反 } \\
\text { 後腿 }\end{array}$ & & 溜 & 麻 & 燘 & & 滤 & & & 部 & & 指脂 & & $\begin{array}{l}\text { 空渴 } \\
\text { 下清 }\end{array}$ & & \\
\hline 式 & 物 & 前 & & 存 & 大留 & & & 發 & 大 & 巴 & 肥 & & & & 出程 & 细充 & 出 & 細充 & 出 & 殺 \\
\hline 名 & $\begin{array}{l}\text { 番 } \\
\text { 㩆 }\end{array}$ & $\left|\begin{array}{c}20 \\
\text { 重 } \\
(\mathrm{kg})\end{array}\right|$ & 别 & $\begin{array}{c}\text { 日 } \\
\text { 晸 }\end{array}$ & $\begin{array}{l}\text { 燃現 } \\
\text { 血日 }\end{array}$ & & 疬 & $\begin{array}{l}\text { 生 } \\
\text { 暗 } \\
\text { 位 }\end{array}$ & ‘ & $\begin{array}{l}\text { 部 } \\
\text { 位 }\end{array}$ & 数 & $\begin{array}{l}\text { 大 } \\
\text { サ }\end{array}$ & 胞 & 血占 & 血胙 & 佨嘼 & & 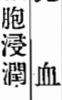 & 血 & $\begin{array}{l}\text { 方 } \\
\text { 法 }\end{array}$ \\
\hline & $6 s$ & 31.0 & P & 38 & 10 & + & - & 小灣 & 示指頭之 & 克指腸 & 多 & 小 & $1+1$ & $+1-$ & & Ht $H$ & + & $\mathrm{tt}$ ttt & + & 嬉弱 \\
\hline $\mathrm{F}$ & 70 & 7.8 & 今 & 73 & 15 & + & - & 幽門 & 示指頭火 & 同 & 少 & 小 & & $t+t$ & & $\mathrm{H}+\mathrm{t}$ & - & HItHt & 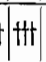 & 空箫 \\
\hline & 71 & 8.0 & $\hat{o}$ & 43 & 10 & - & - & & & 同 上 & 少 & 小 & +1 & +1 & $-1+$ & +-1 & $\mid-1$ & $\pi t+$ & +1 & 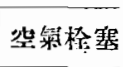 \\
\hline & 72 & 6.5 & $\hat{\delta}$ & 8 & & + & - & & & 同上 & 少 & 小 & tt & +- & $-\mid \pi$ & ++ & - & $+t+$ & - & 腹㬶炎 \\
\hline $\mathrm{G}$ & 74 & 7.0 & $\hat{\delta}$ & 46 & 10 & - & - & & & 同上 & 少 & 穴 & & & -1 & $+1+$ & + & $H$ & - & 校秛 \\
\hline & 75 & 9.2 & $\hat{\delta}$ & 60 & 13 & - & - & & & 局上 & 少 & 小 & & +1 & $-1+$ & ++ & + & ++ & + & 茭殺 \\
\hline & 76 & 7.0 & 우 & 60 & 9 & + & - & & & 同上 & 少 & $\begin{array}{l}\text { 大 } \\
\text { 点 }\end{array}$ & & $+1-$ & -1 & $1+$ & -1 & $\mathrm{Ht}$ & -1 & 尘氣烃塞 \\
\hline $\mathrm{H}$ & 78 & 8.7 & 우 & 70 & 12 & - & 1 & & & 同 & 尜 & $\begin{array}{l}\text { 小 } \\
\text { 中 }\end{array}$ & & $+1-$ & $-t$ & tt $+\mathrm{Ht}$ & $\mathrm{tt}$ & $\mathrm{tt} H \mathrm{Ht}$ & $+t$ & $\begin{array}{l}\text { ス小yt } \\
=2\end{array}$ \\
\hline & 79 & 7.5 & $\hat{\delta}$ & 55 & 12 & - & - & & & 同 上 & 多 & $\begin{array}{l}\text { 火 } \\
\text { 头 }\end{array}$ & $1+1$ & +1 & $-1+$ & $t+$ & $1+1$ & $+1+$ & $|\mp|$ & $\begin{array}{l}\text { ストリ } \\
=\dot{v}\end{array}$ \\
\hline
\end{tabular}




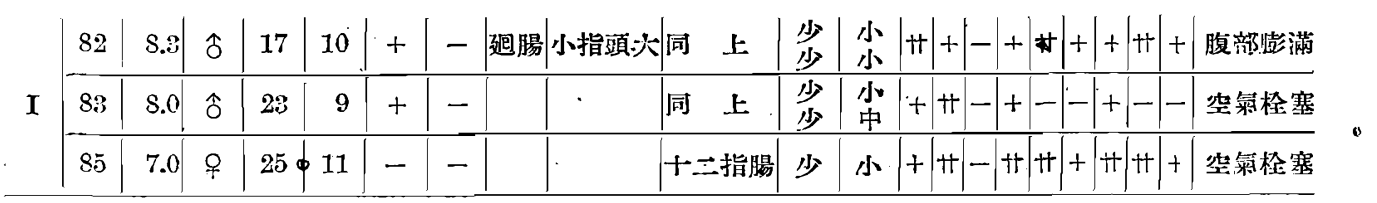

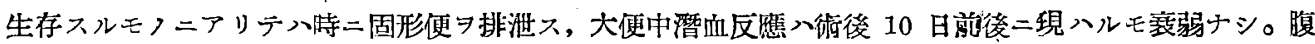

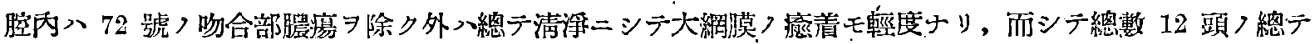

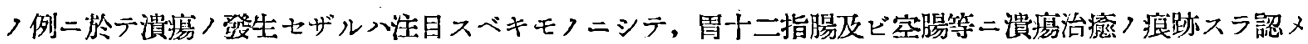

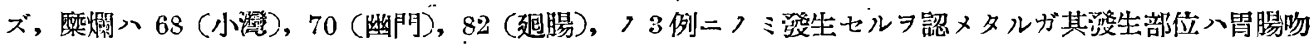
合部 フミニ限定セズ，淋巴濾胞つ腫脹入各例二於テ中等度二認メラル。

\section{第 2 項 胃, 腸管ノ組織學的所見}

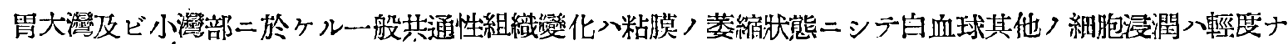

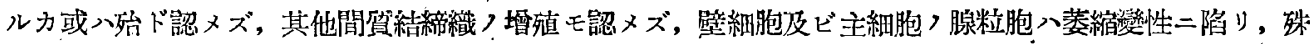
二後者入總テノ例二於テ高度ニシテ原形質入細壞，溶解シ核ノミ殘存セルモ>或八核モ消失シ腺管壁二八 壁細胞ノミ殘存ス。而シテ壁細胞自己二八顆粒出現, 溶解, 空胞化, 核ノ消失等種タナル變性萎縮像ヨ呈 スルモノナリ。幽門部粘膜ニアリテハ各例共細胞浸潤比較的高度ニシテ萎樎及ビ輕度ノ炎㣫性像习認入㱠 ド總デノ例二充血ハアルモ出血入認メズ，細胞浸潤及ビ充血ヨ認ムル例ニアリテハ基底蔀二淋巴細胞ノ集

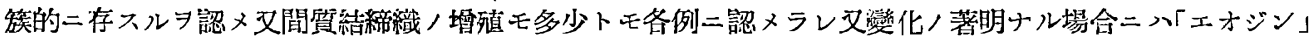
整好細胞,「プラスマ」絧胞等ノ浸潤习特二其〉基底部二多數認メラル。

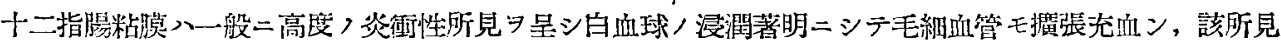

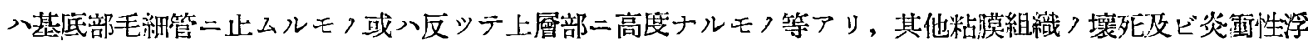

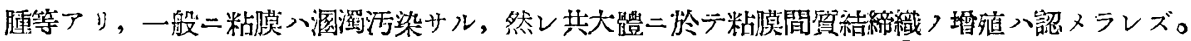

胃腸吻合部二於ヶル空腸及ビ迥腸入炎重性變化高度ニシテ間質二八細胞浸潤, 充血; 出血及ビ浮尰等 認メ總テフ例二著明二認メラルルモ細胞浸閵高度ナル二充血，比較的輕度ナル場合アリ，浮腫入充血二比 例シ間翼結締織，變化入大體二於テ生存日數二比例シ細胞浸潤，比較的輕传ナル場合二八圆形細胞及ビ白

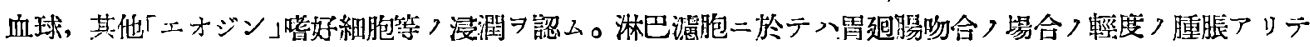

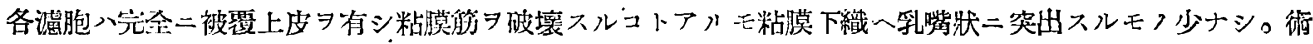

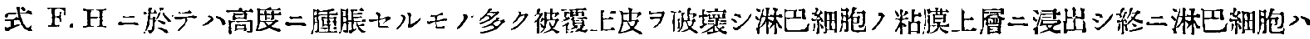

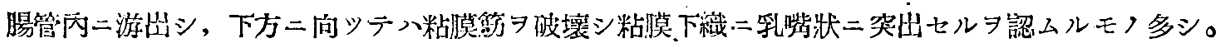

其他粘膜筋, 粘膜下織, 筋層及ビ墏膜 變化入前章ニ於デ記述セシ所見卜大差ナキヨ以ラ省略ス。

以上ニヨリ原式第 3 群 $>$ 特徵 $タ$ 列擧スレバ

(1) 術後一般栄羑狀態可最ニシテ長期二互リ生存ス。

(2) 各例ノ何レノ部分ニモ潰分, 潑生ヨ認メズ。

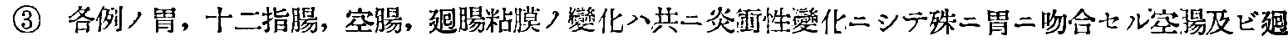
腸入他)腸管二比ジ高度ニシテ, 又術式 F.H 二於テ胃二吻合セザル空揚上部下胃二吻合セル空揚下脚下

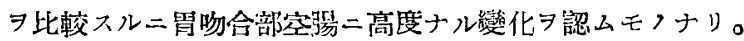

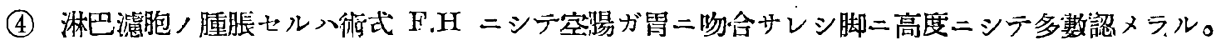

\section{第 6 章術式第 4 媇}

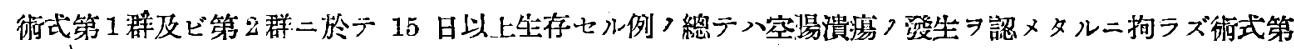
3 群二於テハ, 各消化管〉解剖學的並二組織學的所見名ド同漾ナルニ拘ラズ, 潰瘍フ發生 認メザルハ極

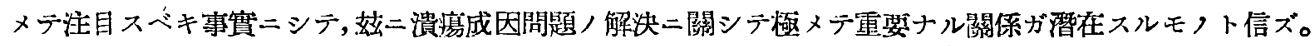
而テ之二關シテ胃內容食慨ガ吻合腸管內゙流通スルヤ否ヤガ特二雷要視スベキ問題ナリト認メラル。而テ 
其主要ナル原因的意義ヨ有スル胃內容トシテハ單二强酸性ナル胃液自身ナルカ將亦食慨ナルカ／問題ヨ提 供スルモフナリ。依テ余入更二次つ如キ實驗ヨ行へリ。郎于胃陽吻合ヨナス腸管二全ク食物ヨ通過セザル

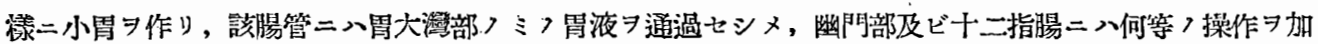
フルコトナク 小腸下端二腸端側吻合ヨナス。(術式 J. K) 又他方二於テハ本術式＼cjkstart加フル二幽門輸二テ十

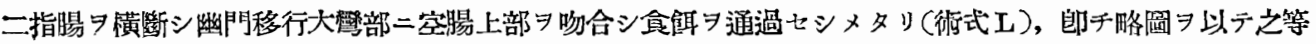
ヨ示セバ次ノ如シ。
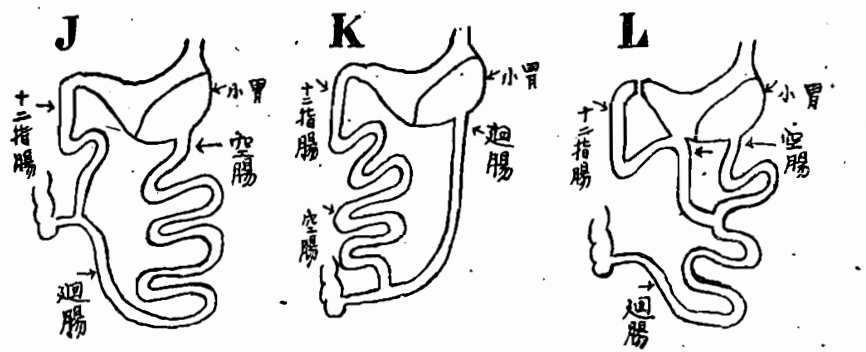

第 1 笁 術式 J / 實驗成綪

Nr. $86, \hat{0}, 7.5 \mathrm{~kg}$.

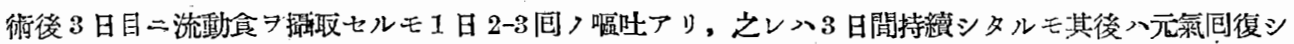

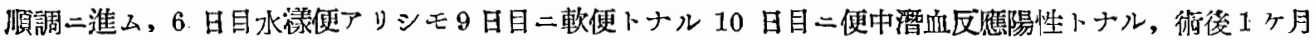

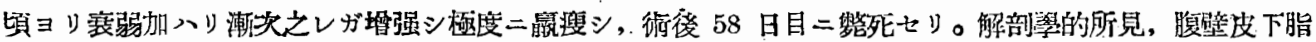

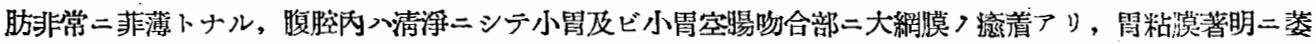

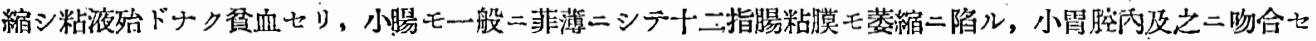

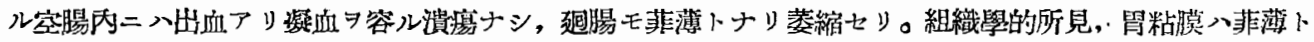
ナリ，細胞浸閵入認メズ上皮細胞及ビ腺細胞つ萎縮ニ傾ケリ，基底部毛縕血管〉處々二充血ヨ認ムルモー

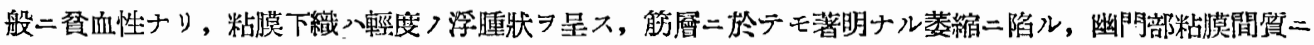

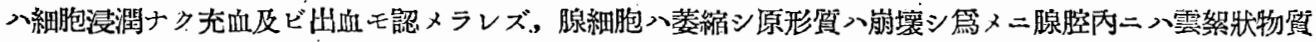

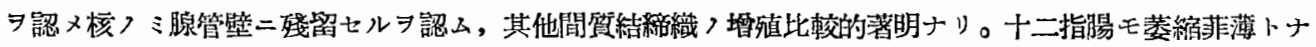

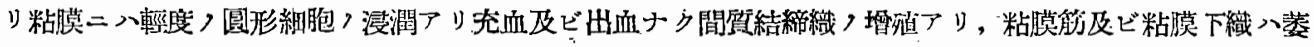

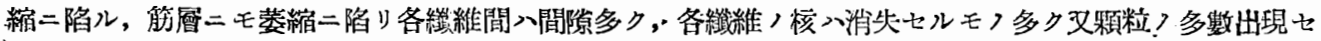

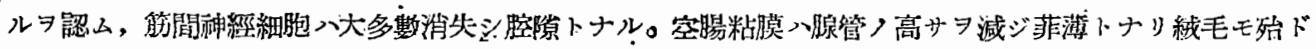
ナク，間質二八圆形細胞及ビ白血球中等度二浸潤アリ又結締織增殖モ認メラル，毛細血管入充血スルモ出

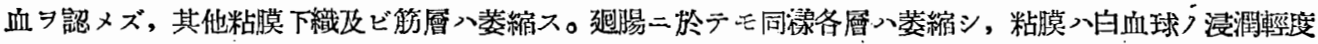
ニアリ，粘膜下織入浮腫狀习呈シ各層，毛細血管八輕度〉充血 7 認么。小胃及之二吻合セル空腸粘膜二於

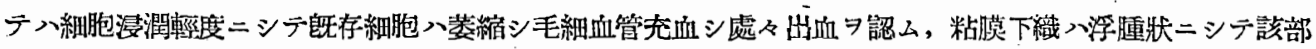

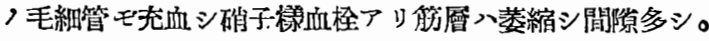

Nr., 87, ô, $8.0 \mathrm{~kg}$,

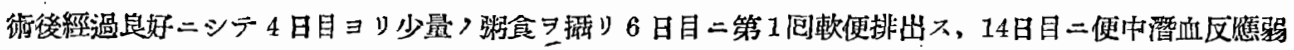
陽性テリシモ爾來普通消化便二順次移行シ元氣トナル, 術後 50. 日目ニ「ストリヒン」皮下注射ニヨリ死二

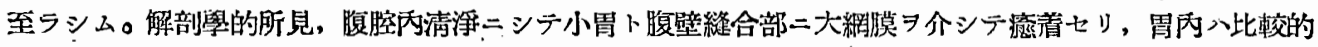

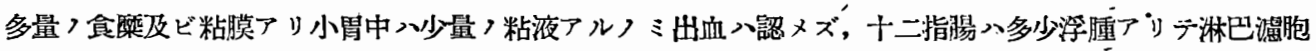

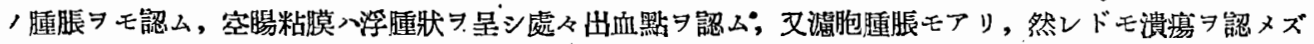

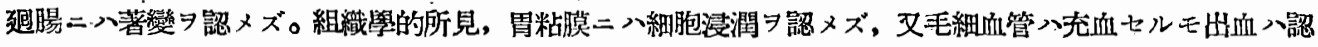

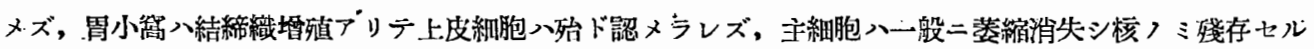


モノ多シ而シテ基底部二稍々其概造 ヨ保テルモノノ核入濃染ス, 壁細胞モ亦萎縮狀ヨ呈シ原形質ノ崩壤或

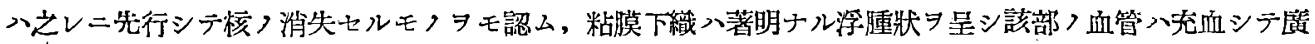

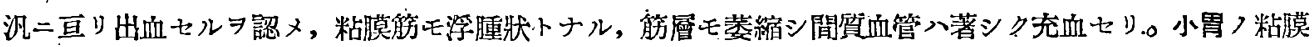

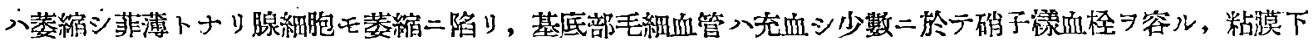

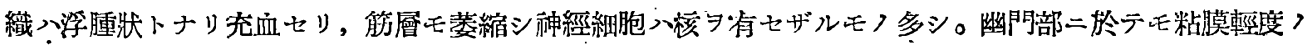

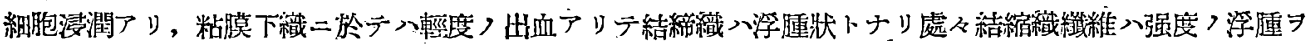

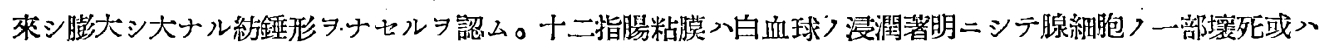
萎縮シ杯狀細胞入殆ド認.メラレズ，毛細血管入充血セルモ出血ナシ，粘膜筋及ビ粘膜下織入著明ナル浮腫

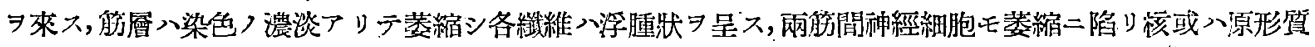

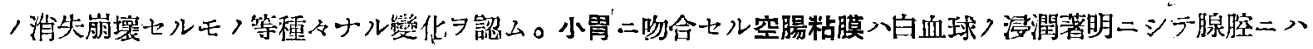

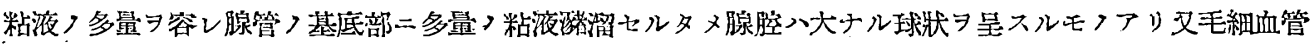

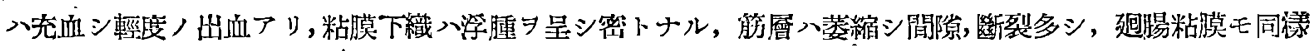

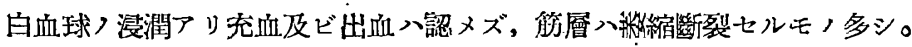

Nr., 90, 우, 6.5kg.,

術後嘔吐モナク元氣アリテ順調二潐ム, 多少裏弱アルモ理動活潑ナリ, 15 日目二便中潛血反應陽性トナ ル, 便八初メ下痢便ナリシモ次第二通常便トナル, 衎後 68 日目ニ「ストリヒニン」皮下注射ニヨり致死七

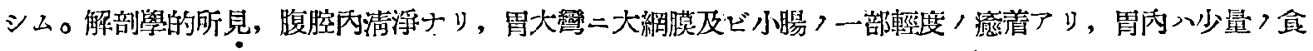

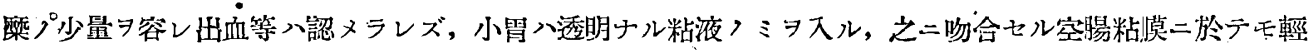

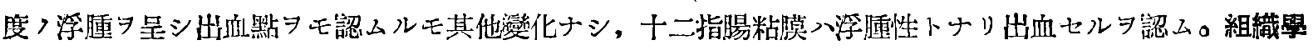
的所見, 胃粘膜こ入輕度，圓形細胞浸潤アリ基底部:入入處々淋巴細胞〉集園七ルアリ腺細胞入萎縮變性二

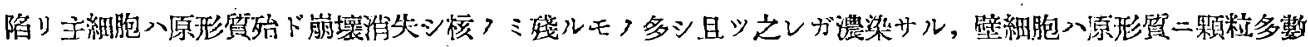
出現シ淡染ス文崩壤シツ、アルモ 或入消央シ空胞漾二認メラルルモ，等アリ，毛細血管二入充血アルモ

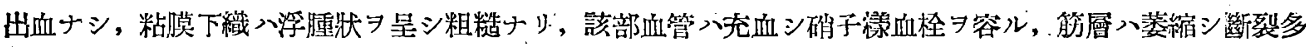

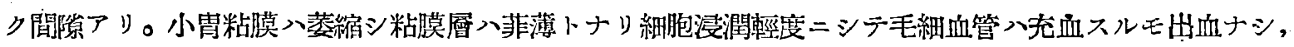

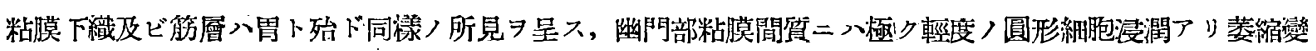

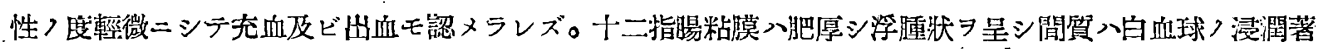
明ニシテ毛細血管ニモ强度ノ古血及ビ出血ヨ認ム, 粘膜下織入浮腫ヨ呈シ毛細血管入大部分硝子漾血栓习

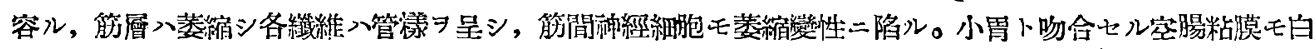

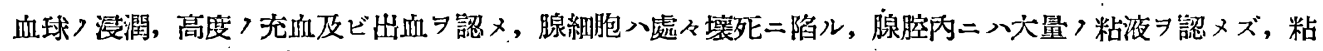

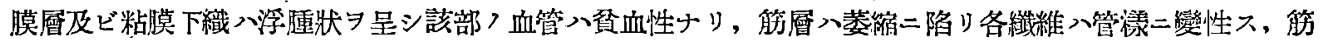
膜ニ在ル血管入充血シ處々硝子漾血栓アリ。

\section{第 2 節 術式 $K$ ノ.筫䭻成綪}

Nr., 91, ㅇ, 7.8kg.,

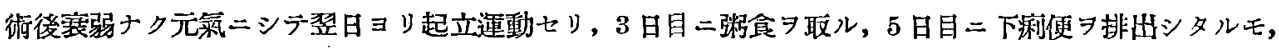
以後順次普通便二移行シ, 18 日目二便中浼血反應陽性トナル, 術後 30 日目二絞殺セり, 解剖學的所見,

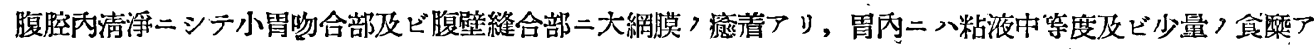

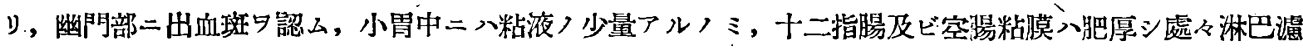

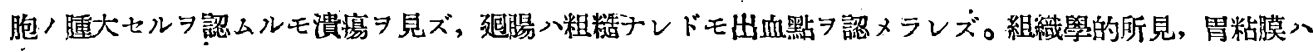

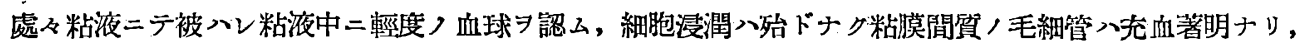
粘膜基底部二淋巴細胞, 集團セルヨ認ム, 粘膜下織入輕度つ浮腫狀トナリ該部ニアル此較的大ナル血管， ミ充血ス。筋層入輕度, 萎縮ヨ示ス。幽門部粘膜二八圓形細胞及ビ白血球〉浸潤アリ, 處々淋巴滤胞,腫 脹セルモノモ認ム, 又粘膜上皮习被覆セル粘液中二多嘍〉赤血球, 混在セル习認么。十二指腸粘膜八肥厚シ 


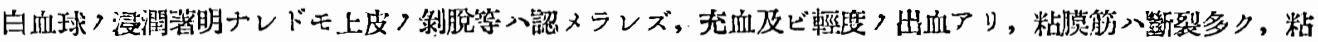

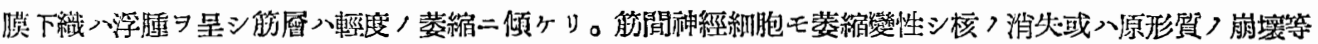

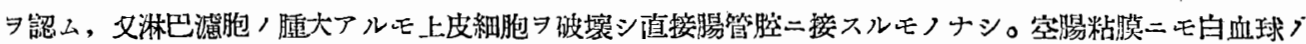

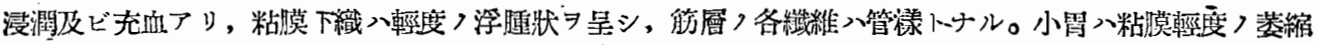

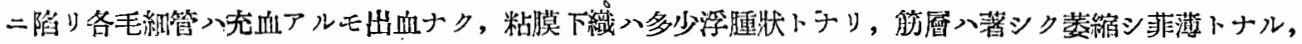

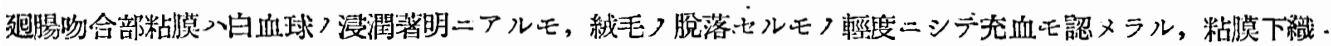

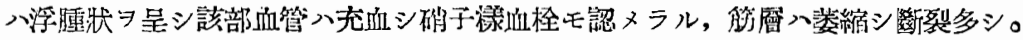

ㅍr., $98, \hat{0}, 7.5 \mathrm{~kg}$.

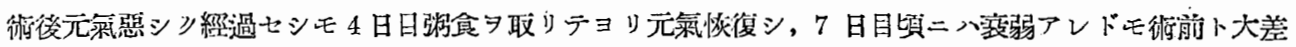

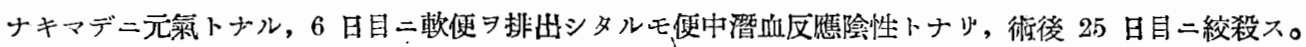

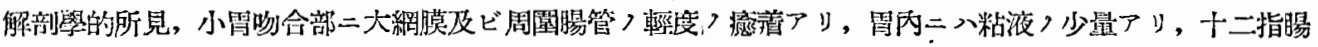

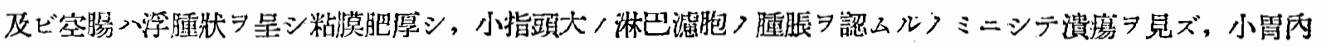

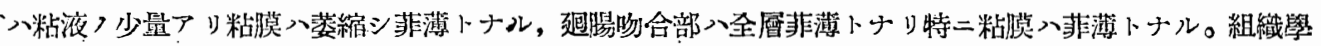
的所岳, 胃粘膜細胞浸潤小ク上皮細胞及ビ腺細胞二八著變 ヨ認メズ, 固有層二於ヶル毛細管入充血シ硝子

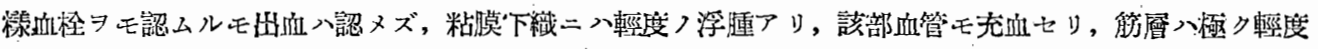

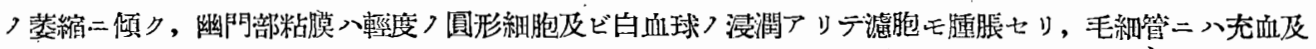

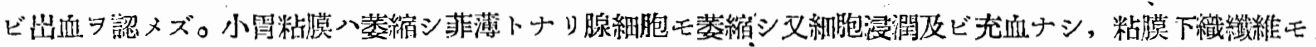

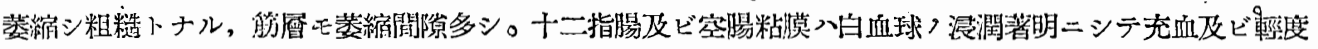

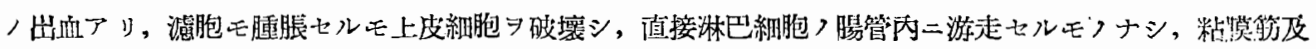

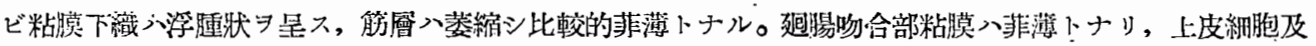

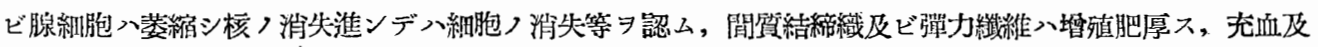

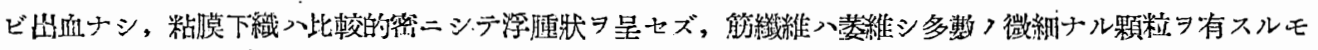

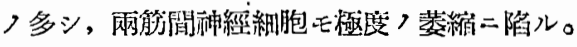

Nir., 91, $\hat{0}, 7.0 \mathrm{~kg}$,

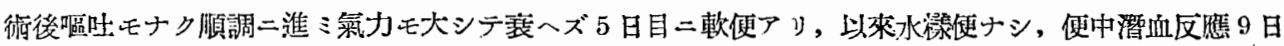

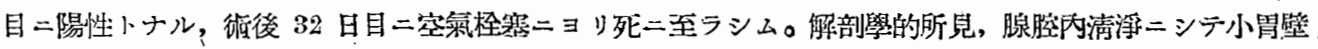

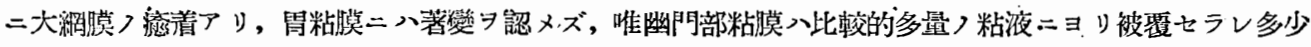
萎維狀態ナリ，小胃粘膜ハ少量つ粘液アリテ著シク菱縮シ壁モ菲薄トナル。十二指腸及ビ空腸入多少浮腫

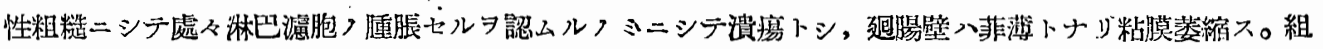

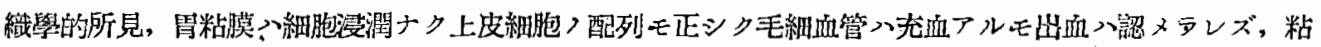

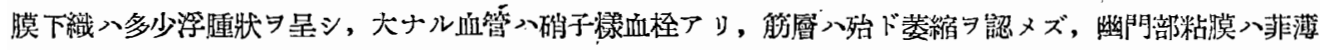

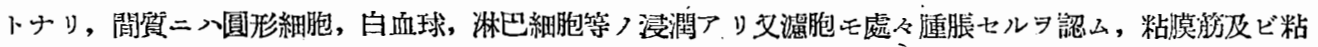

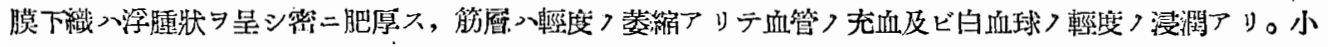

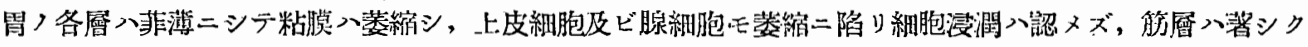

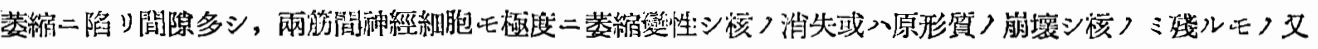
空胞形成等习認么。十二指晹及ビ空腸粘膜八肥厚シ白血球，浸潤著シク毛細血管八充血シ，淋巴溜胞八腫

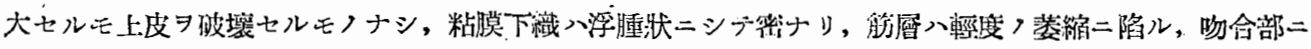

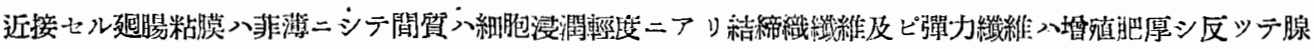

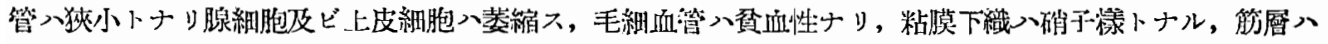

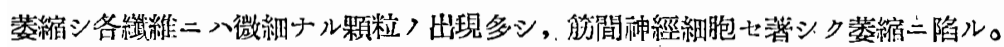

\section{第 3 節 術式 $\mathbf{L}$ /惯驗成綪}

N.. $96, \hat{o}, 10.5 \mathrm{~kg}$. 


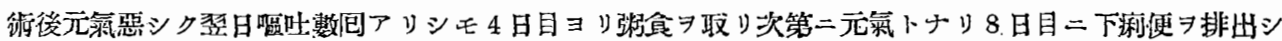

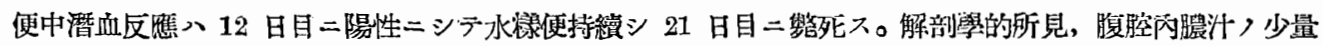

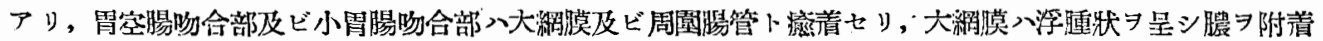

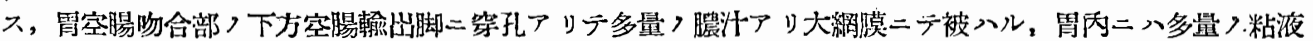

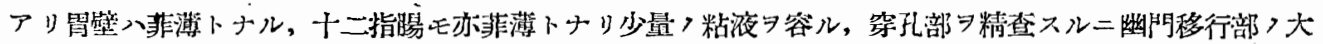

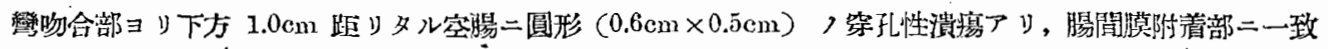

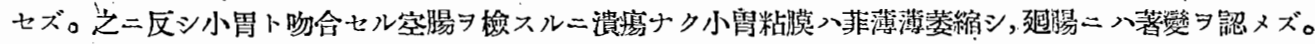

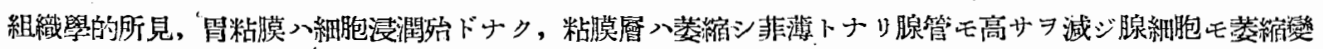

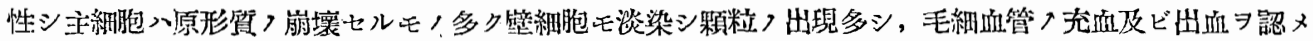

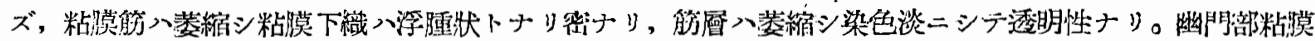

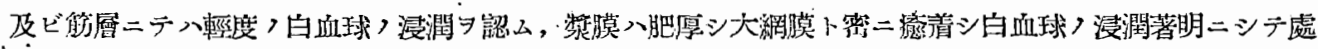

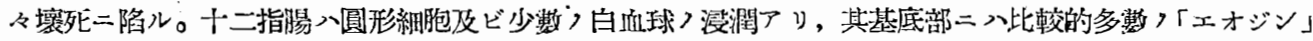

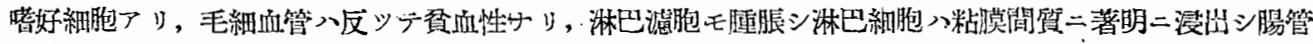

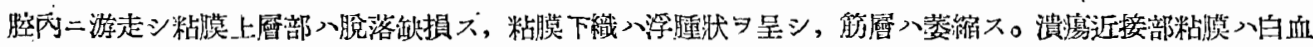

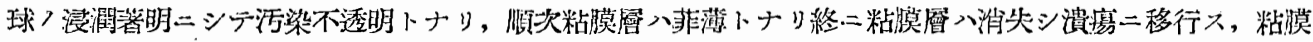

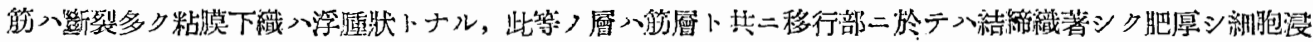

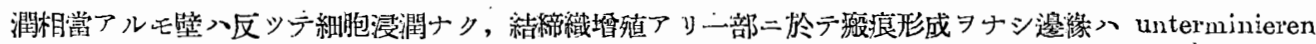

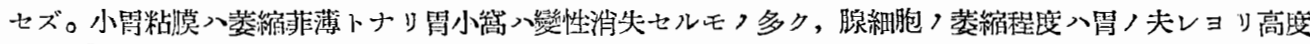

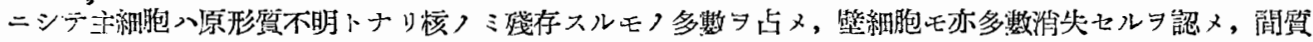

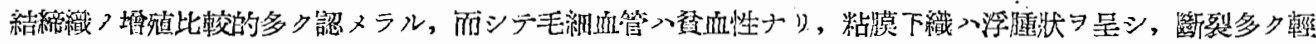

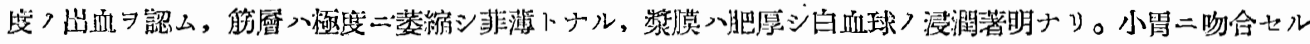

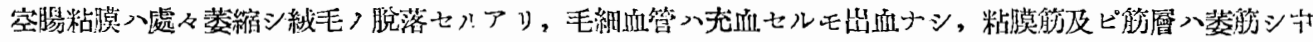

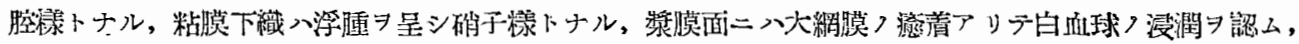

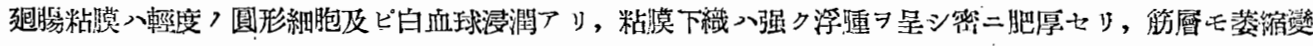

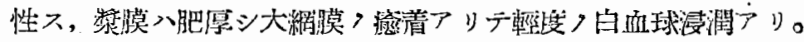

Nir. 97, $\hat{0}, 8.5 \mathrm{~kg}$.

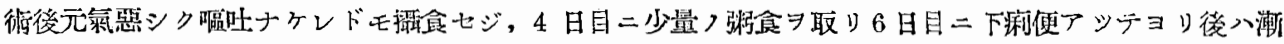

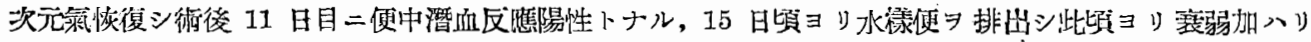

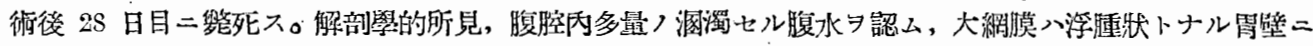

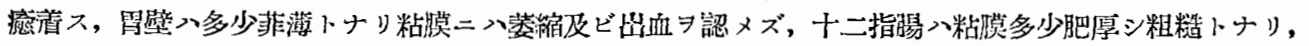

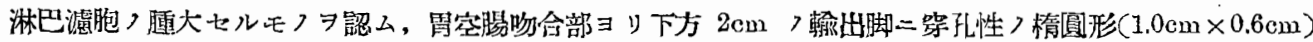

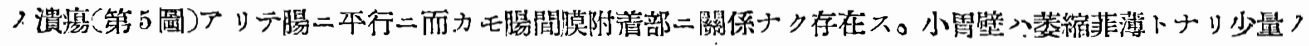

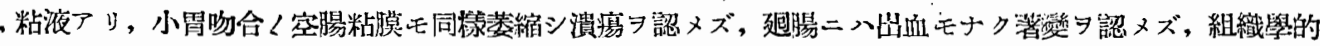

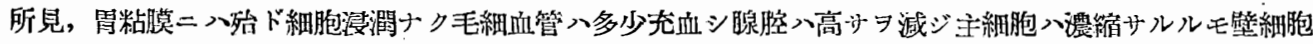

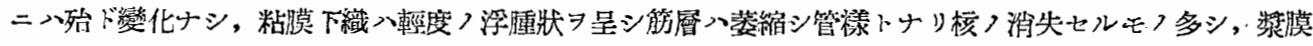

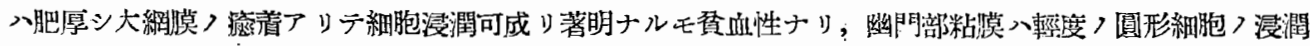

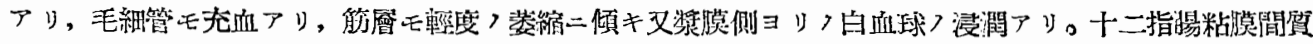
こ八白血球及ビ「エオジン」赀好細胞等アルモ主トシラ圆形細胞つ浸潤アリ又輕度ノ充血アルモ出血入認又

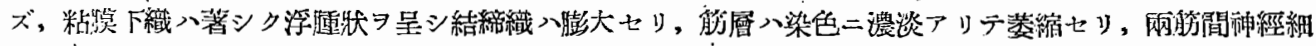

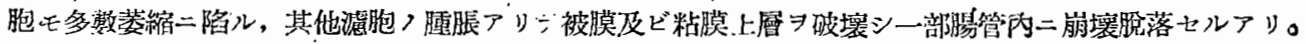

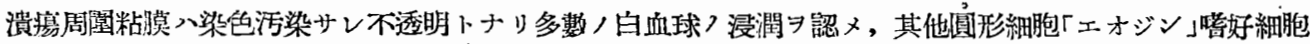

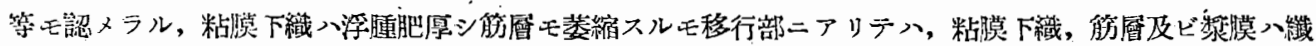




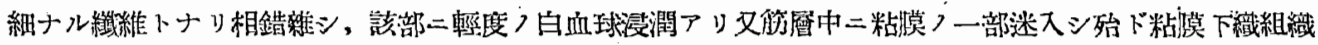
こョリ包埋セラル，其他演瘍壁ニ於ヶル神經細胞入高度二萎縮變性ス。小胃粘膜層入菲溥ナラザルモ腺細 胞入菱縮シ主細胞及ビ壁細胞〉消失或フ變性セルモフ多シ，毛細血管入輕度つ充血フルモ細胞浸潤ナシ，

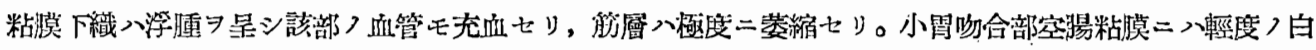

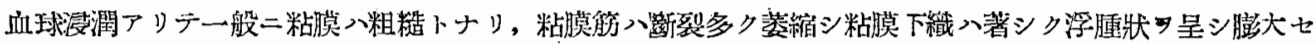

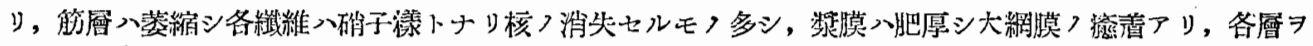
通ジ一般二血管入空虚ナリ。

Nir. 99, ิิ, 8.0kg.,

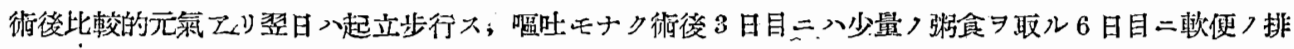

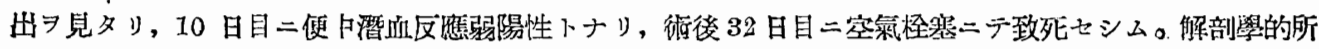

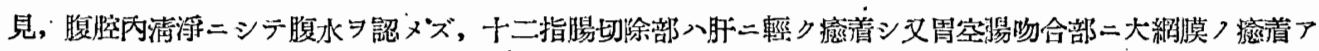

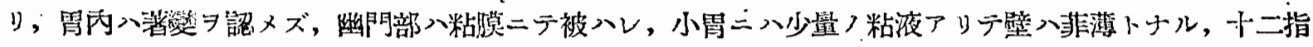

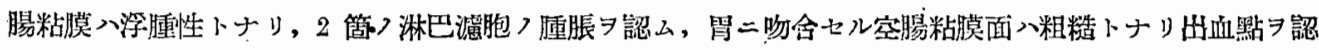

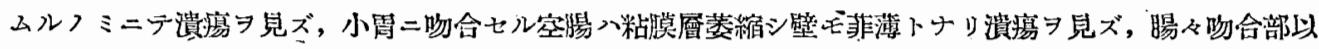
F>粘膜面二處々出血點习認么, 其他變化ナシ。組織學的所見, 胃粘膜八細胞搌潤ナク處々淋巴細胞つ小

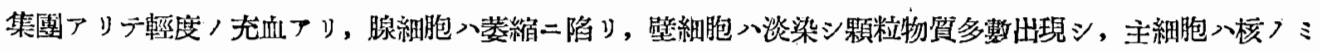

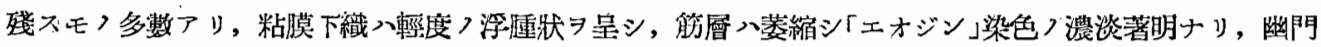

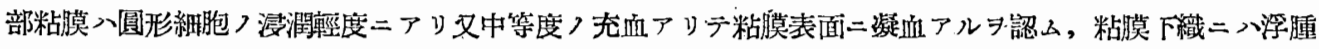

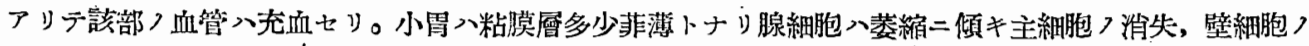

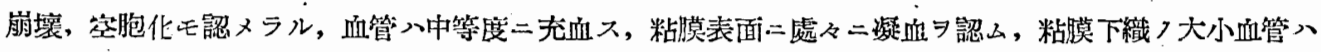

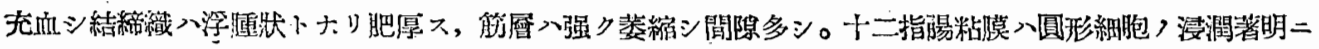

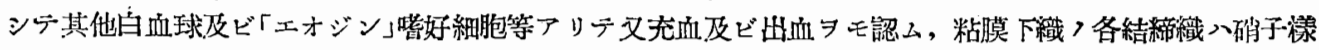

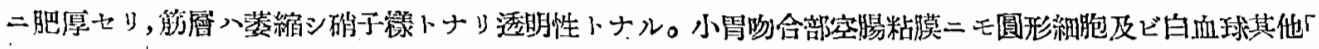

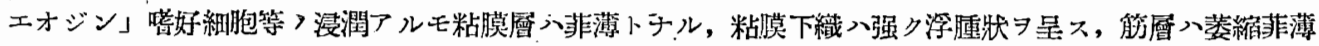

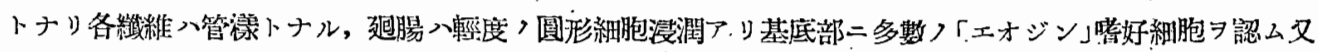
充血及ビ輕度，訮血アリ，該部粘膜下織モ强ク浮腫狀ニシテ筇層入萎縮ス。

\section{第 4 節 術式第 4 群ノ實驗成綪小括（第 6 表參照）}

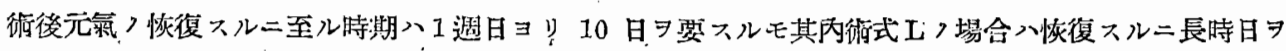

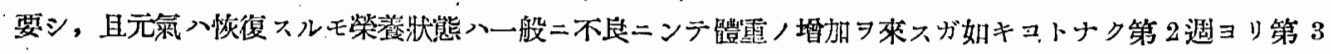

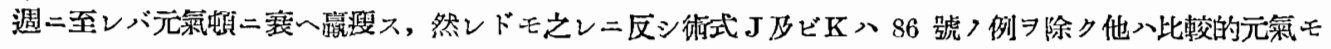

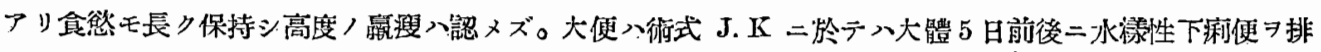

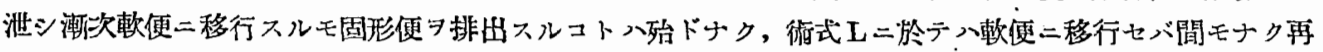

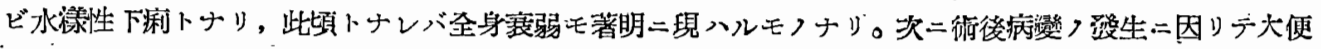

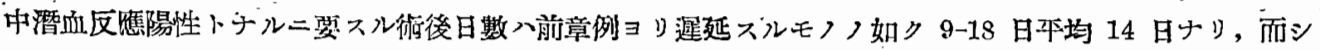
テ其程度ハ前章ニモ記述セル如ク每常同一程度ヨ示サズ時トシテハ經過中除性ノコトモ認メラル, 然レ共 術式几ノ場合八濑㳄反應增强スルヨ通例ドス。

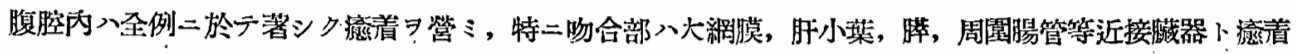

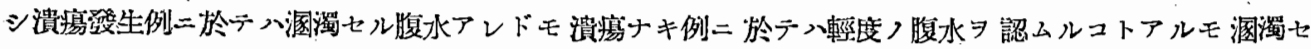

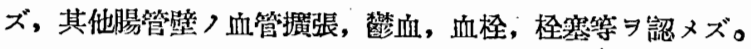

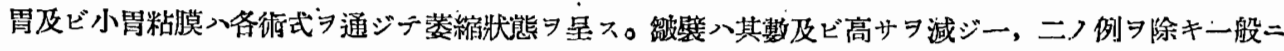

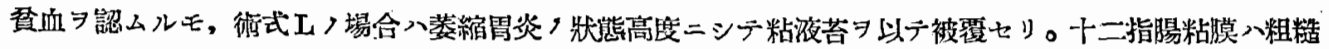
ニシテ浮腫狀タ呈ス。小胃吻合ノ空腸或入迴腸粘膜:於テモ其面ハ粗䊎ニシテ白血球及ビ圓形細胞，浸潤 
アリ浮腫狀ヨ呈スルモノ多ク又充血及ビ出血斑ヨ認ムルコトアリ。術式 $L=$ 於ヶル十二指腸, 胃空腸物合 輸出脚及ビ小胃空腸吻合 > 各陽粘膜八高度

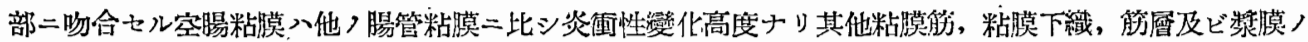

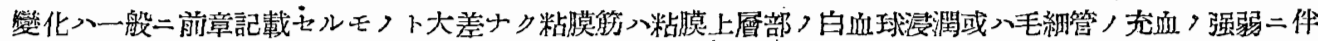

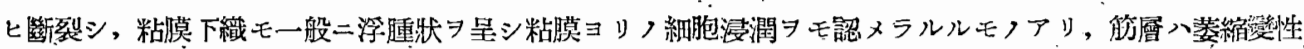

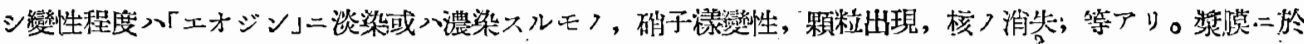

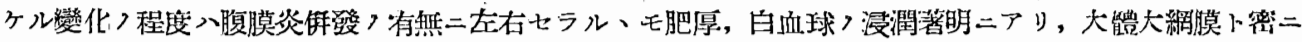
丞着セり, 此他入大體二於テ前章)變化卜大差ナシ。(第 6 表參照)

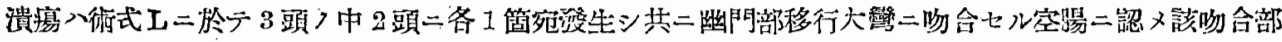
第 6 表 術式第 4 群/解剖所見總括

\begin{tabular}{|c|c|c|c|c|c|c|c|c|c|c|c|c|c|c|c|c|c|c|}
\hline 術 & 動 & 術 & 性 & 衡 & 畐應 & 鎚 & & 淂 & 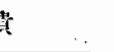 & & 疮 & & & & 爛 & & & \\
\hline & 物 & $\begin{array}{l}\text { 前 } \\
\text { 體 }\end{array}$ & & 生 & 便泏 & 使 & & 部位 & 犬 & 形 & 穿 & $\begin{array}{l}\text { 莩 } \\
\text { 綵 }\end{array}$ & 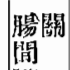 & $\begin{array}{l}\text { 湾 } \\
\text { 生 }\end{array}$ & 突 & - & 笣 & . \\
\hline 吅 & $\begin{array}{l}\text { 番 } \\
\text { 號 }\end{array}$ & 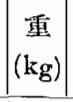 & 別 & $\begin{array}{c}\text { 甾 } \\
\text { 日 } \\
\text { 数 }\end{array}$ & $\begin{array}{l}\text { 潛現 } \\
\text { 现 }\end{array}$ & $\begin{array}{l}\text { 有 } \\
\text { 無 }\end{array}$ & 胃 & 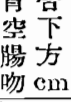 & サ & 狀 & $\begin{array}{l}\text { 有 } \\
\text { 無 }\end{array}$ & 起 & 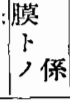 & 位 & サ & $\begin{array}{l}\text { 部 } \\
\text { 位 }\end{array}$ & 數 & $\begin{array}{l}\text { 大 } \\
\text { サ }\end{array}$ \\
\hline & 86 & 7.5 & $\hat{\delta}^{\circ}$ & 58 & 10 & + & - & & & & & & $\therefore$ & & & $\mid$\begin{tabular}{|c|} 
f二指腸 \\
空腸上蔀
\end{tabular} & 䒚 & \begin{tabular}{|l|} 
小 \\
小
\end{tabular} \\
\hline $\mathbf{J}$ & 87 & 8.0 & $\hat{o}$ & 50 & 12 & - & - & & & & & & & & & 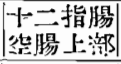 & \begin{tabular}{|l} 
少 \\
少
\end{tabular} & \begin{tabular}{|l} 
小 \\
小
\end{tabular} \\
\hline & 90 & 6.5 & 우 & 68 & 15 & - & $1-$ & & & & & . & & & . & & & \\
\hline & 91 & 7.8 & 우 & 30 & 18 & + & - & & & , & & & & 幽門 & 示指頍大 & 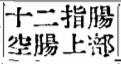 & 䒚 & $\begin{array}{l}\text { 小 } \\
\text { 小 }\end{array}$ \\
\hline $\mathrm{K}$ & 93 & 7.5 & $\hat{\delta}$ & 25 & 13 & + & - & & & & & & & & & 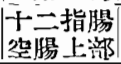 & 少 & $\begin{array}{l}\text { 中 } \\
\text { 小 }\end{array}$ \\
\hline & 94 & 7.0 & $\hat{\delta}$ & 32 & 9 & - & $1-$ & & & & & & & & & 。 & & \\
\hline & 96 & $\mid 10.5$ & $\hat{o}$ & 21 & 12 & + & - & 1.0 & $|0.6 \times 0.5|$ & 圆形 & + & + & - & & & 十二指腸 & 多 & 大 \\
\hline $\mathbf{L}$ & 97 & 8.5 & $\hat{o}$ & 28 & 11 & -1 & - & 2.0 & $1.0 \times 0.6$ & 棈圓形 & + & + & - & & & \begin{tabular}{|c|c|}
+ & 指腸 \\
至腸上部
\end{tabular} \mid & 多 & 夼 \\
\hline & 99 & 8.0 & $\hat{\delta}$ & 32 & 10 & + & - & & & & & - & & & & |千二指腸 & 少 & 大 \\
\hline
\end{tabular}

第 7 表 庄式策 4 群, 組織學的所見總括

(H 著明, H 中等度, + 輕㛺)

\begin{tabular}{|c|c|c|c|c|c|c|c|c|c|c|c|c|c|c|c|c|c|}
\hline 術 & 動 & 悳 & 溃 & & 門 & & 小 & & & & 二指 & & & 偒上 & & & \\
\hline 名 & $\begin{array}{l}\text { 物 } \\
\text { 番 } \\
\text { 號 }\end{array}$ & 告 & 有 & $\begin{array}{l}\text { 娚田 } \\
\text { 浸 } \\
\text { 潤 }\end{array}$ & 血 & 出 & 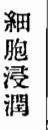 & 光 & 出 & 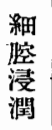 & 充 & 出 & 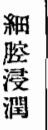 & $\begin{array}{l}\text { 充 } \\
\text { 血 }\end{array}$ & 出 & $\begin{array}{l}\text { 殺 } \\
\text { 方： } \\
\text { 法 }\end{array}$ & \\
\hline $\boldsymbol{J}$ & $\begin{array}{l}86 \\
87 \\
90\end{array}$ & $\begin{array}{l}58 \\
50 \\
68\end{array}$ & $\begin{array}{l}\overline{-} \\
\overline{-}\end{array}$ & \pm & 柾 & III & $\begin{array}{l}+ \\
+ \\
+\end{array}$ & $\begin{array}{l}+1 \\
+ \\
+\end{array}$ & \pm & $\begin{array}{l}+ \\
H \\
H\end{array}$ & $\bar{E}$ & $\bar{m}$ & $\begin{array}{l}\text { H } \\
\text { H+ } \\
\text { HI. }\end{array}$ & $\begin{array}{l}+ \\
+ \\
+H\end{array}$ & $\begin{array}{l}- \\
\dot{+} \\
+1\end{array}$ & $\begin{array}{l}\text { 裏 } \\
ス ト y 七= \\
\text { ストリヒ= }\end{array}$ & \\
\hline K & $\begin{array}{l}91 \\
93 \\
94\end{array}$ & $\begin{array}{l}30 \\
25 \\
32\end{array}$ & $\overline{-}$ & $\begin{array}{l}+ \\
\text { t } \\
\text { t }\end{array}$ & $\frac{\pi}{t}$ & $\begin{array}{l}- \\
-\end{array}$ & $\begin{array}{l}+ \\
-\end{array}$ & $\frac{+}{+}$ & $\bar{z}$ & $\underset{H}{\text { W }}$ & $\begin{array}{l}+1 \\
+ \\
+\end{array}$ & + & $\begin{array}{l}+\# \\
\text { H } \\
\text { H }\end{array}$ & H & $\overline{-}$ & $\begin{array}{l}\text { 校 } \\
\text { 絞 } \\
\text { 空氣 栓 }\end{array}$ & 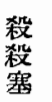 \\
\hline $\mathbf{L}$ & $\begin{array}{l}96 \\
97 \\
99\end{array}$ & $\begin{array}{l}21 \\
28 \\
32\end{array}$ & $\begin{array}{l}+ \\
+ \\
-\end{array}$ & $\begin{array}{l}+ \\
+ \\
+\end{array}$ & $\begin{array}{l}\text { H } \\
+1 \\
+1\end{array}$ & $\frac{t}{t}$ & $\stackrel{+}{+}$ & $\bar{I}$ & $\overline{-}$ & $\begin{array}{l}H \\
+1 \\
H\end{array}$ & $\frac{-}{\pi}$ & $\bar{z}$ & $\begin{array}{l}H_{H} \\
+ \text { tht } \\
\text { tIt }\end{array}$ & $\begin{array}{l}\pi \\
+ \\
+\end{array}$ & $\begin{array}{l}+ \\
+ \\
+\end{array}$ & 空 氣 栓 & 塞 \\
\hline
\end{tabular}




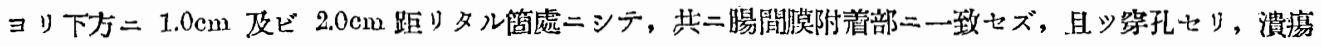

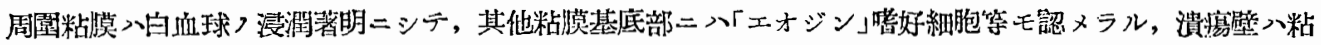

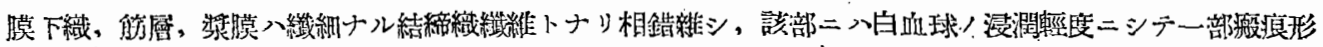

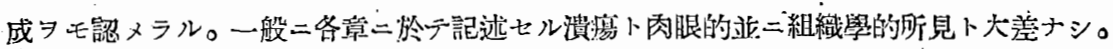

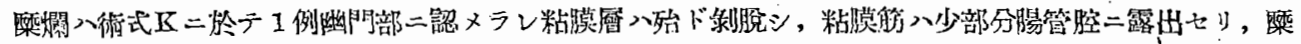

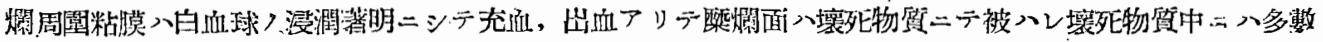
ノ赤血球习認么。

淋巴㶓胞，腫脹ハト二指腸及ビ空腸上部二最モ著明二認メラレ特二術式し二㙷著小り。組織學的所兒二

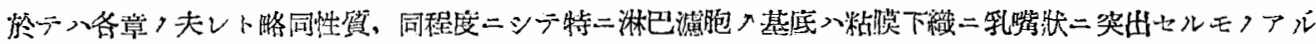

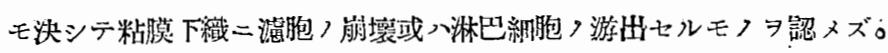

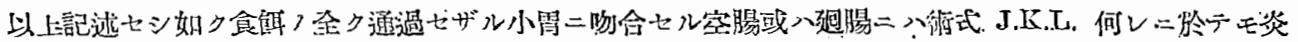

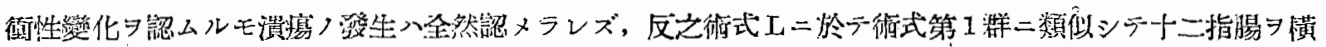

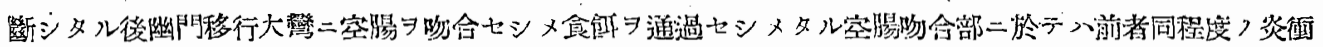

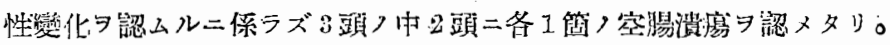

\section{第 7 章 術式第 5 群}

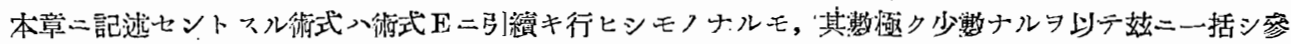

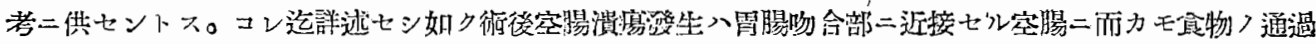

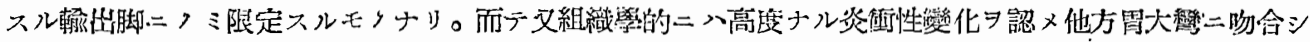

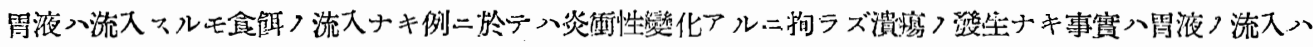

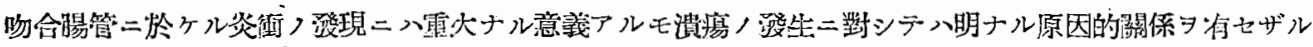

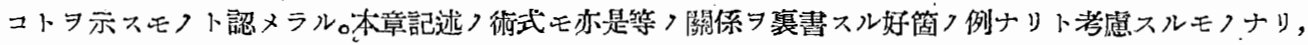

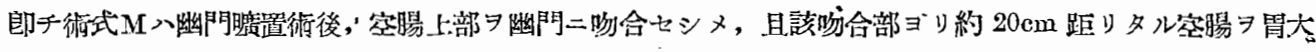
綮二㕫合シ幽門液及ビ十二指腸液ヨ胃吻合部二作用セシメタリ。

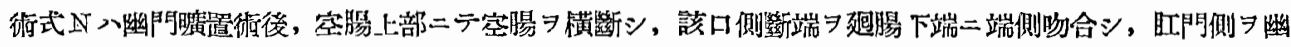

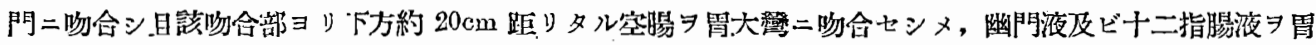
腸吻合部二及ビ迥腸下端二分流セジタタリ。

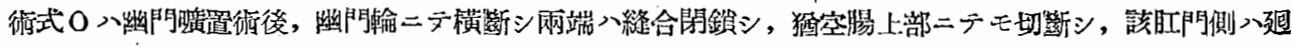
腸下端二端側吻合シ，口側入幽門部二吻合セシメ，且幽門空腸吻合部ヨリ下方 $20 \mathrm{~cm}$ 距リタル空腸 胃大

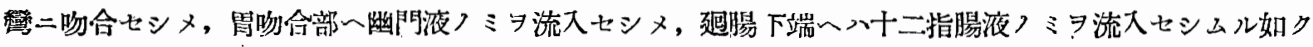
施行セり。

$$
\text { 次二其略圖ヨ示サン。 }
$$
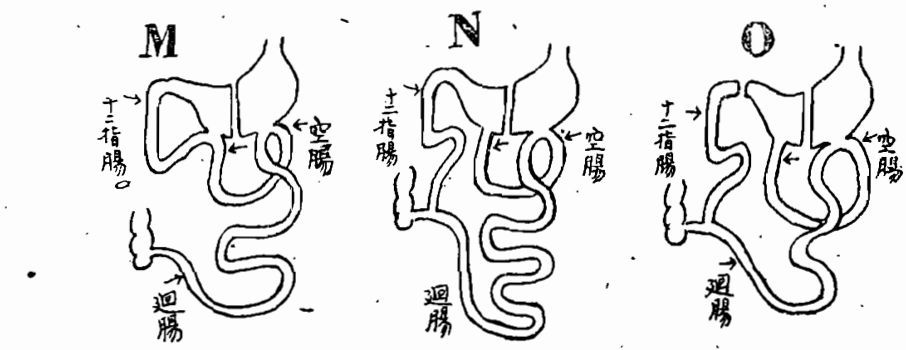

第 1 節 䁇 驗 成 綪

Nr. 58., 令, 12.0kg., 行式 M.

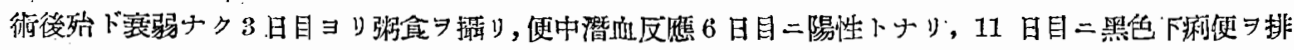


出, 順次水注性トナリ, 全身極度つ衰弱アリ, 䘗後 20 日目ニシテ擎死ス。解剖學的所見, 腹腔內多量

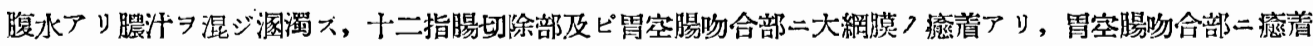
セル網膜入浮腫性トナル，胃ニハ少量つ粘夜アル：ミニシテ切斷サレシ幽門部二モ少量つ粘夜アリテ粘膜

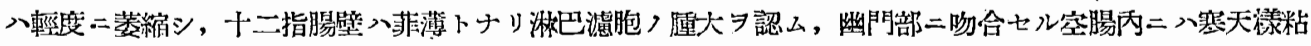

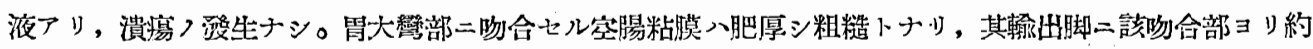

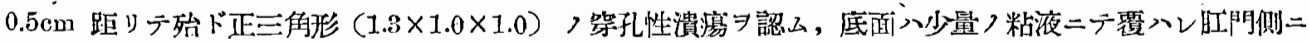
近ク，帽針頭大>略圓形，穿孔部アリ，迴腸及ビ腸端側吻合部二八著變ナシ。組織學的所見，胃粘膜八細

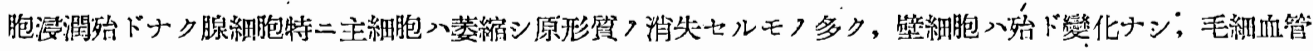

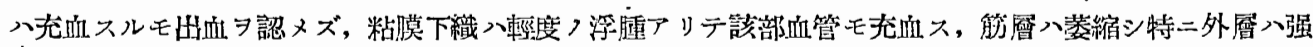

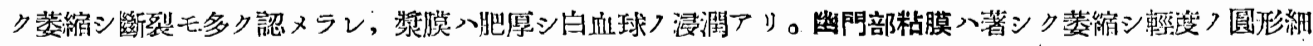

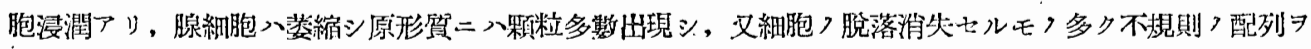

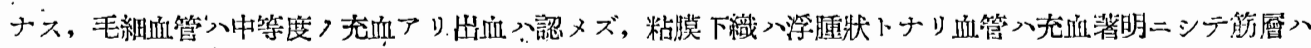

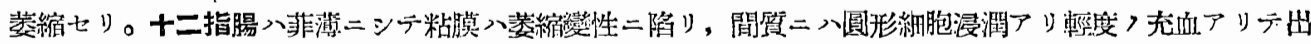

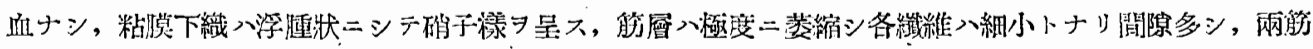

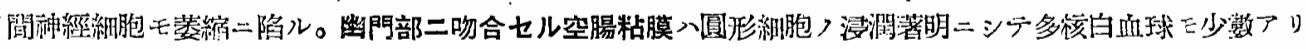

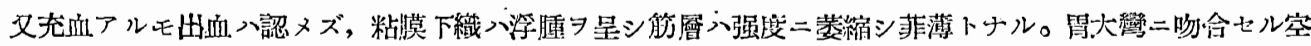

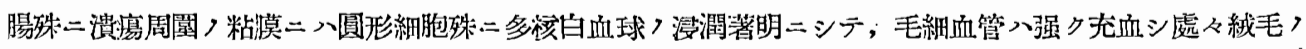

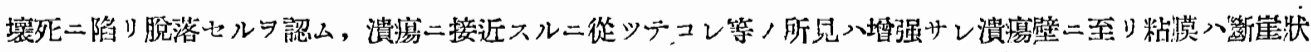
ヨナシテ消失ス, 粘膜筋入萎縮細小トナリ斷裂多ク, 粘膜下糡入浮腫狀トナリ密二肥厚シ, 移行部二於テ

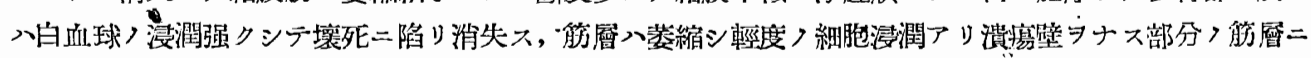

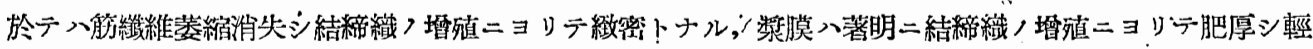

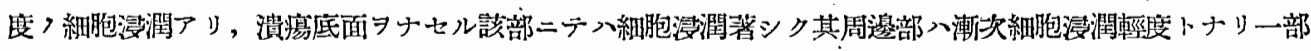

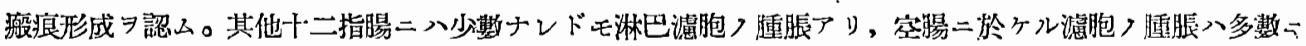
シテ高度ナリ。

Nr., 57,'合, 10.5kg., 術式 $N$.

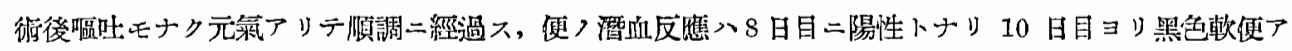

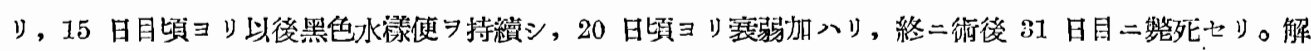

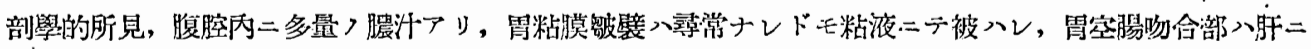

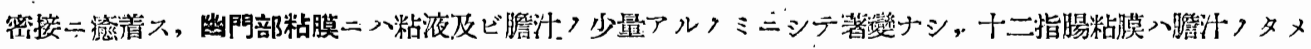

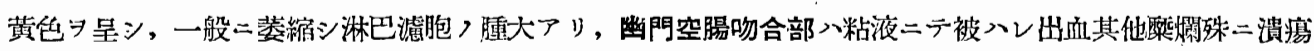
ナシ。

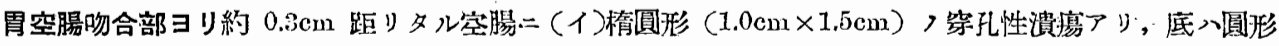

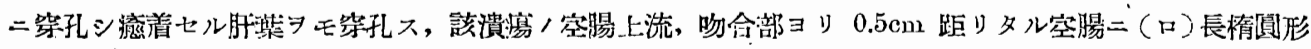

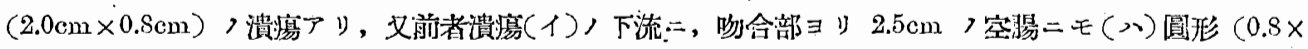

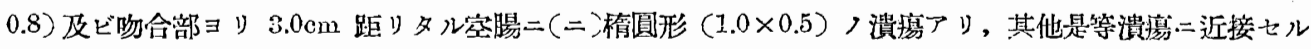

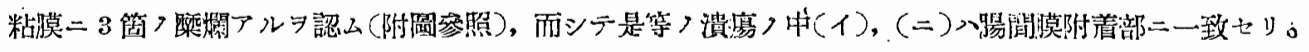

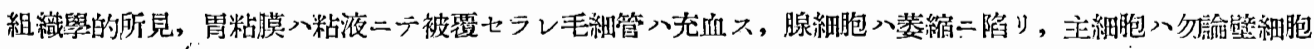

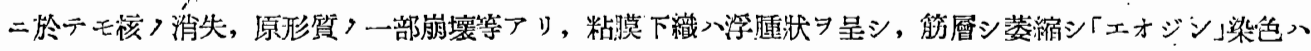

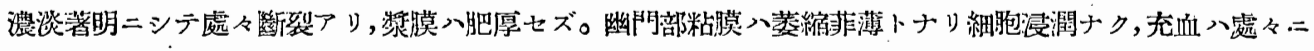

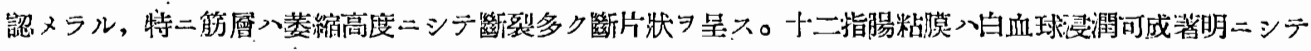

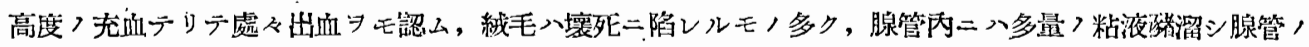

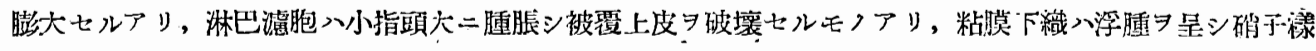




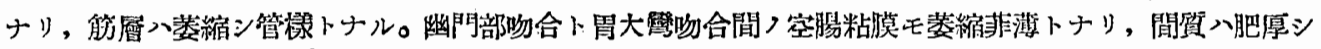

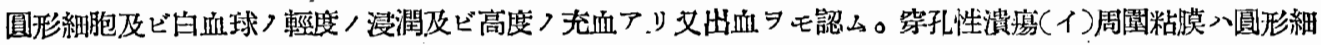

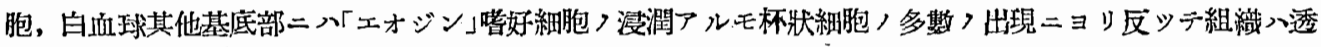
明性ニシテ且毛細血管, 高度, 充血アリ, 潰瘍壁ニ至レバ斷崖狀二壞死消失シ, 粘膜下織入高度, 浮喢狀

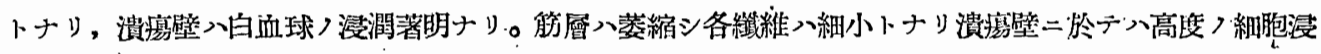

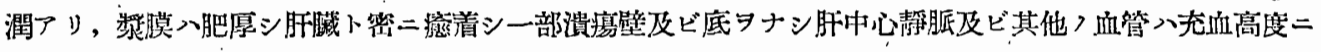

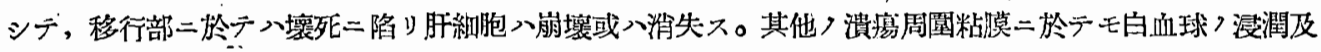

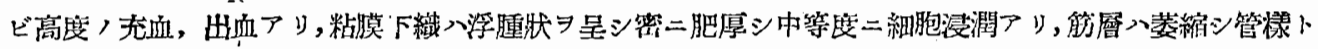

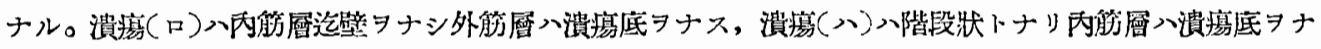

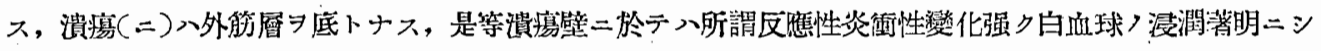

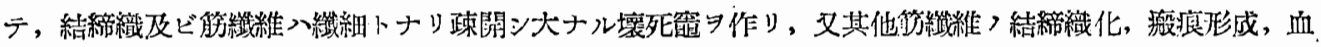

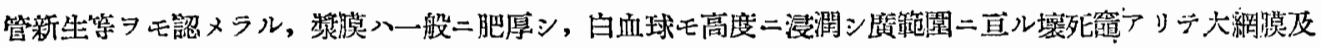

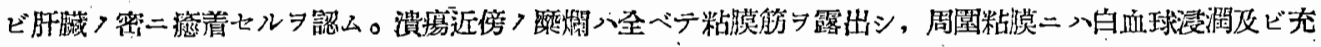

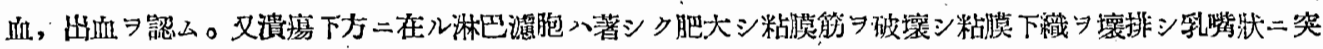

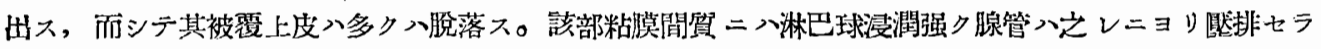
ル。又腸管腔內二モ, 其跈出セルモフコ認么。

Nr., 60, ㅇ, $12.0 \mathrm{~kg}$, 惦式 O.

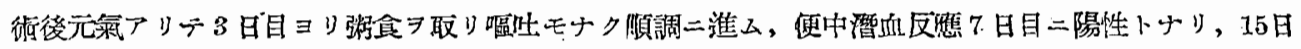

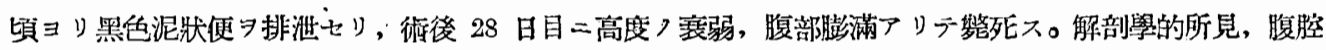

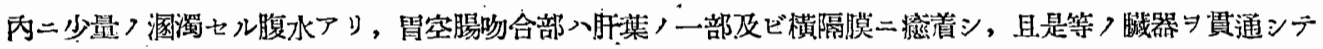

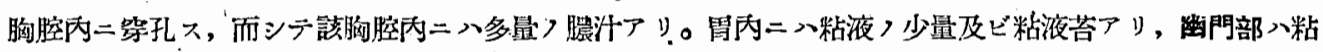

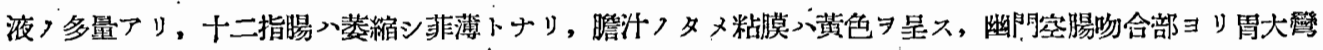

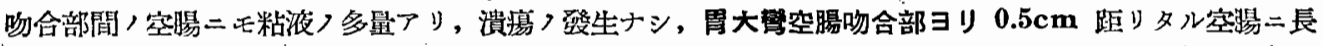

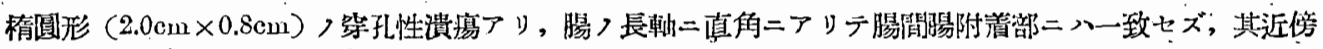

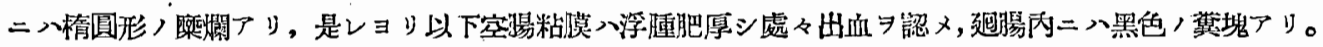
組織學的所見，胃粘膜二八細胞浸潤ナク萎縮非薄トナリ，腺細胞二八微細ナル顆粒多数出現シ，核〉消失 及ビ細胞ノ崩壞ヨ認ム，毛細血管八高度，充血アリ，吻合部二近キ胃粘膜八白血球〉浸潤渚明ニシラ腺細

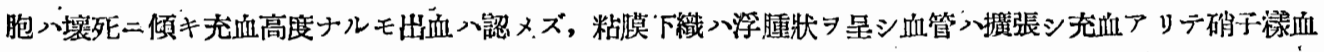

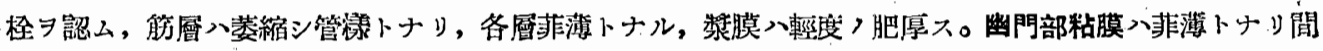

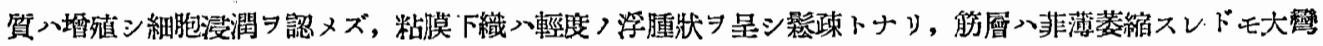

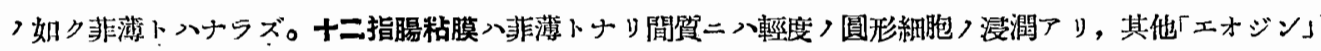

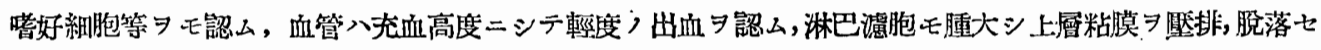

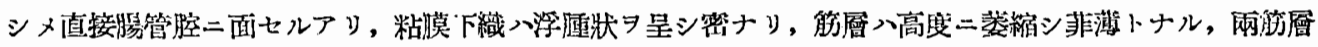

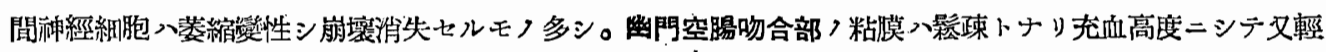

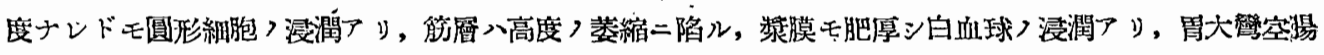

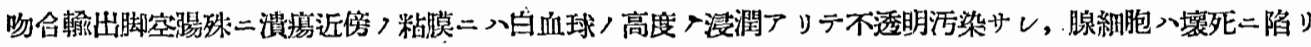

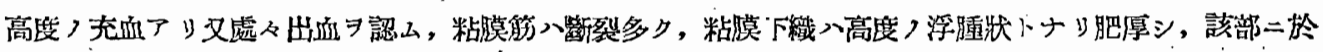

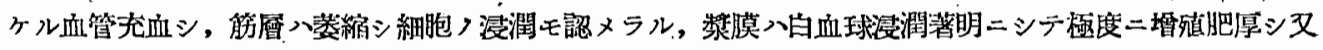

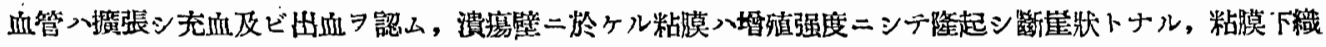

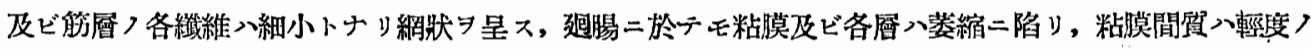
冭血及ビ圓形細胞，浸潤ヨモ輕度ニアリ。

\section{第 2 簛 小 括 (第 8 表參照}




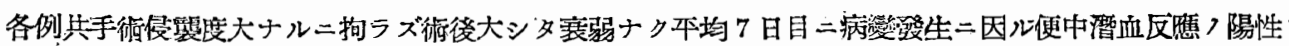
ヨ示シ, 10-15 日,間ヨり黑色下痢便习排泄シ, 其頃ヨリ漸次衰弱シ初ジム。

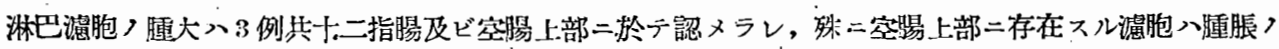

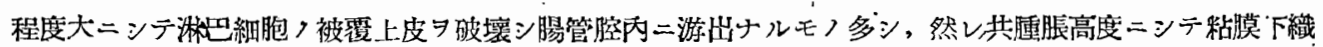

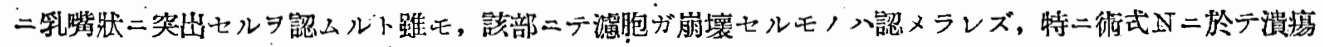
二近接セル㵂胞ニ於テモ認メランズ。

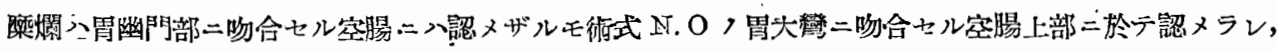

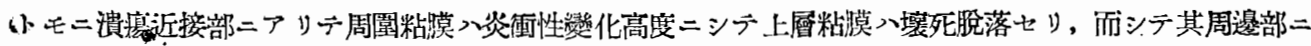
ハ淋巴溜胞入認メズ。

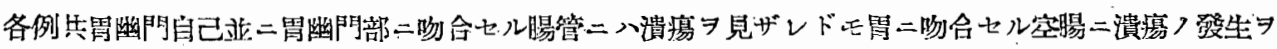

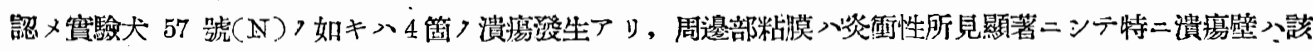
第 9 表 術式第 5 群 $/$ 解剖並二組絨學的所見概括

\begin{tabular}{|c|c|c|c|c|c|c|c|c|c|c|c|c|c|c|c|c|c|}
\hline 醇動 & 惦 & & & 行反 & 鉢 & & 潰 & & & 瘙 & & & 糜 & 爛 & & & \\
\hline & 前 & & & 受應 & 使 & & 部位 & 大 & 形 & 穿 & 邀 & 腸 & & & & 佨 & \\
\hline 番 & $\begin{array}{c}\text { 體 } \\
\text { 重 } \\
(\mathrm{kg})\end{array}$ & & & & $\begin{array}{c}\text { 用 } \\
\text {, } \\
\text { 有 } \\
\text { 無. }\end{array}$ & 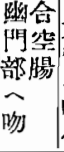 & 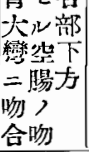 & サ & 狀 & $\begin{array}{l}\text { 扎 } \\
\text { 有 } \\
\text { 無 }\end{array}$ & ? & 關 & $\begin{array}{l}\text { 生 } \\
\text { 暗 } \\
\text { 位 }\end{array}$ & サ & $\begin{array}{l}\text { 部 } \\
\text { 位 }\end{array}$ & 數社 & $\begin{array}{l}\text { 大 } \\
\text { サ }\end{array}$ \\
\hline$M \mid 58$ & 12.0 & $\hat{o}$ & 20 & 6 & + & - & $0.5 \mathrm{~cm}$ & $\mid \begin{array}{l}1.3 \times 1 \\
\times 1.0\end{array}$ & 三角形 & + & + & + & & & 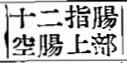 & 省 & 大 \\
\hline 57 & 10.5 & & 31 & 8 & + & - & \begin{tabular}{|l|}
$0.3 \mathrm{~cm}$ \\
$0.5 \mathrm{~cm}$ \\
$2.5 \mathrm{~cm}$ \\
$1.0 \mathrm{~cm}$
\end{tabular} & & 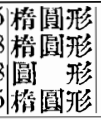 & $\begin{array}{l} \pm \\
\pm \\
-\end{array}$ & $\begin{array}{l}+ \\
+ \\
+ \\
+\end{array}$ & $\begin{array}{l}- \\
+ \\
+ \\
-\end{array}$ & 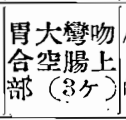 & & 十二指腸 & $\begin{array}{l}\text { 多 } \\
\text { 多 }\end{array}$ & $\begin{array}{l}\text { 犬 } \\
\text { 大 }\end{array}$ \\
\hline$|60|$ & 12.3 & 우 & 28 & 7 & + & -1 & $0.5 \mathrm{~cm}$ & $2.0 \times$ & |棈圓形| & + & + & - & $\mid$\begin{tabular}{|l|l|}
$\mid$ 局上空腸 \\
上部
\end{tabular} & 帽針頭大 & 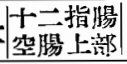 & 多 & 犬 \\
\hline
\end{tabular}

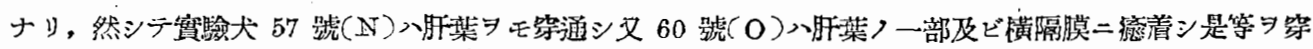

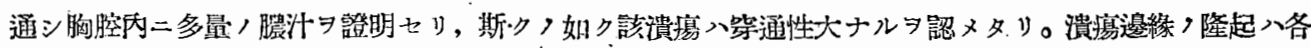

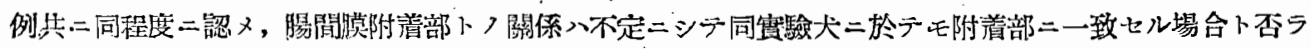
ザル場合トアり。

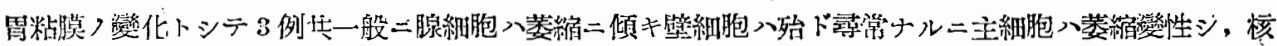

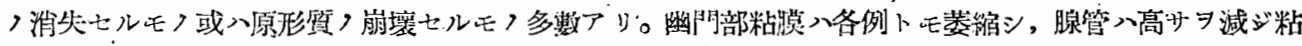

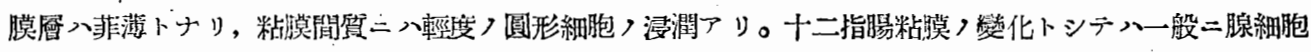

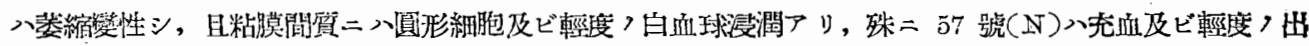

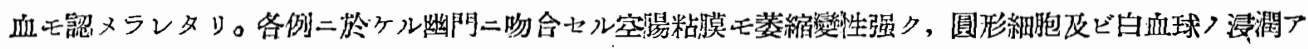
ルモ極ク輕度ナリ。然レドモ吻合部二接近スルニ從ッテ圆形細胞及ビ白血球フ浸潤濑㳄增强シ其他充血宅

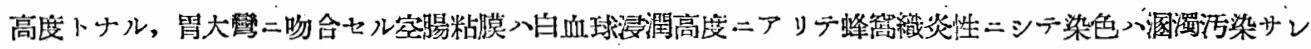

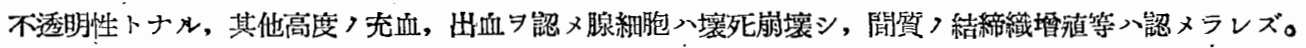
然シテ下流ニ降ルニ從ツテ該變化入漸次輕度トナル。

\section{第 8 章 術式第 6 群}

第 1 節 術後流動食ノミア以テセル潰福發生二就テ

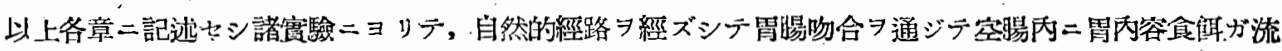

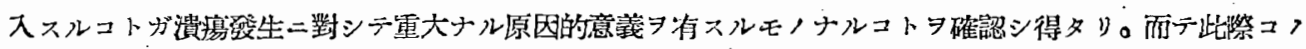

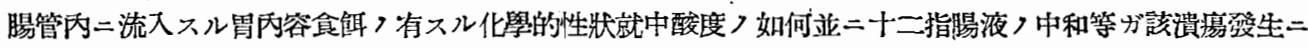




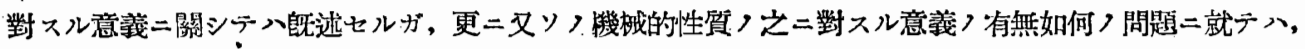

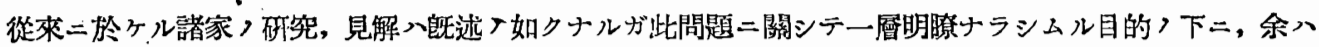

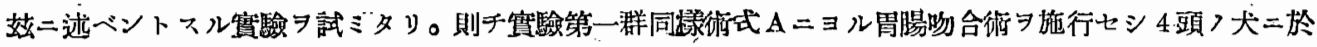

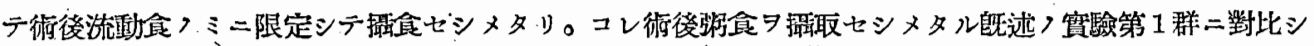

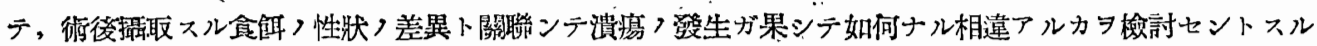
モノナリ。

今其實驗成綪 シ略述セバ次, 如シ。

Nr. 100, 合 體軍 8.5

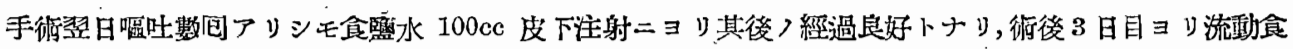

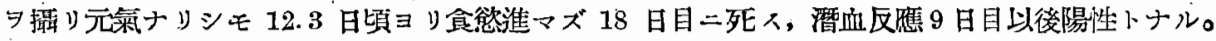

\section{剖見所見}

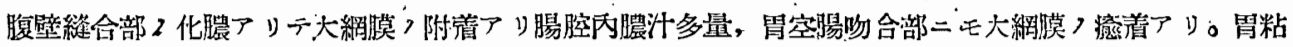
膛變化ナシ，空腸上部粘膜萎縮シ菲薄トナル。潰場ヨ見ズ。

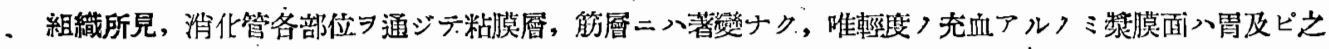
二吻合セラレタル小腸近接部二於テ八可ナリ强度，炎症性變化アリ，多核白血球立二大單核絊胞主トシテ

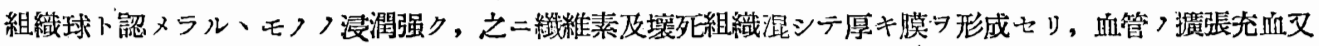

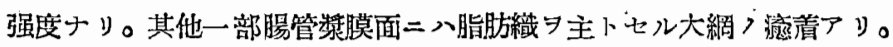

Nir. 101 ô. 軆央 11.0

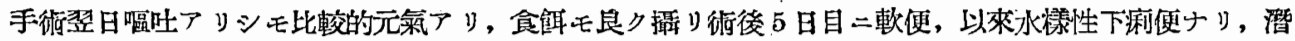
血反㤫ハ14 日目ニ陽性トナレリ。27 日目死亡。

\section{剖見所見}

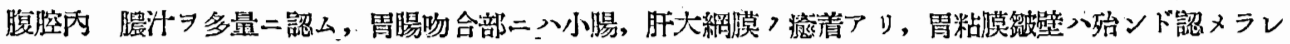

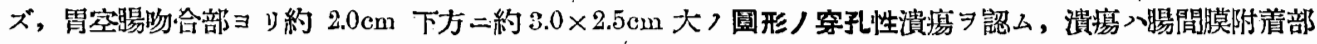
ニ一致せズ，空腸上部粘膜二八血色〉黛便习處々二認ム。

組織所見，潰瘍發生部习除キテハ胃腸各部位下モ著變ナキモ, 粘膜表層八一般二溷濁腫脹, 染色性不良.

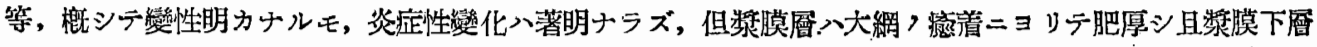
入浮腫性肥厚著明ニンテ大單核性細胞〉輕度ナル核潤アシ。筋層入概シテ變性强ク種々，變化・旺セリ。 十二指腸二於テモ略同绿所見 $习$ 呈セリ。

Nr. 102 क 體重 9.2

術後元氮ニシテ流動食 7 多量ニ取ル, 術後 3 日目ノニ下便アリ, 以來 3 日目二1包位/普通便アリ黑色 ヨ帶ビズ, 裏弱殆ンドナシ, 潛血反應終二認メラレズ, 40 日日二殺ス。

\section{副見所見}

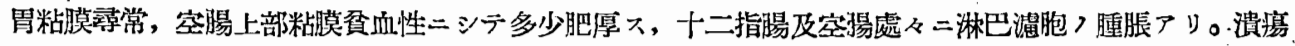
ナシ。

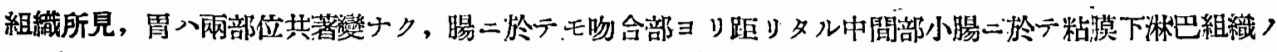
輕度つ增殖卜廻腸下部二大網, 癒着ヨ認メタル外執レモ著變ケシ。

Nir. 103 合 體重 10.5

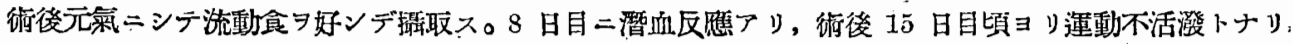
20 日目二死ス。

\section{剖見所見}

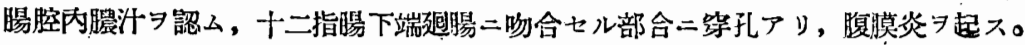

胃粘膜尋常, 空腸上部粘膜入强度二肥厚セルヨ認ム。 
組織所見, 趣腸上部，胃吻合部二近接セル部二於デ粘膜上皮層八變性, 壤死二陷リ殊二一部二於デ 入 急激ナル變性萎縮, 消減ニヨリテ潰瘍

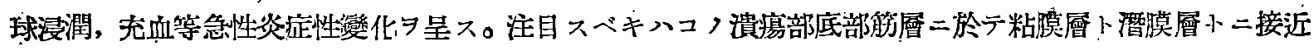

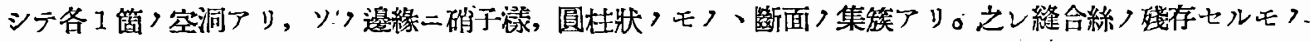

ト認メラレ, 從テ空洞八縫合創ナリト認メラル。

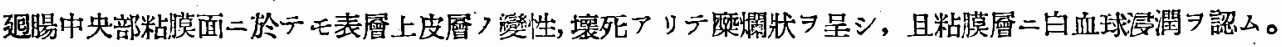

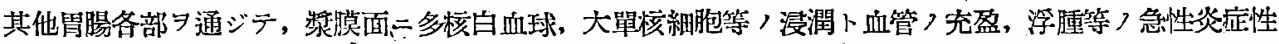

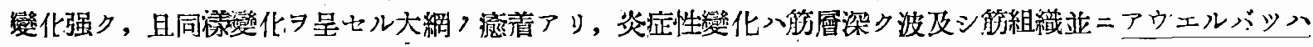
氏神經笁細胞等, 强キ變性习認メラル。

\section{第 2 節 小 括 (第 9 表參照)}

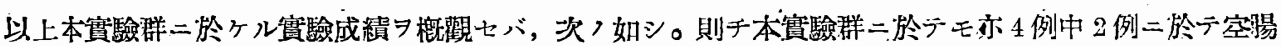
第 9 表 第6 群八解剖所見總括

\begin{tabular}{|c|c|c|c|c|c|c|c|c|c|c|c|c|c|c|c|c|c|}
\hline \multirow[t]{3}{*}{ 術 } & \multirow{2}{*}{$\begin{array}{l}\text { 動 } \\
\text { 物 } \\
\text { 番 }\end{array}$} & \multirow{2}{*}{$\begin{array}{l}\text { 術 } \\
\text { 前 }\end{array}$} & \multirow[t]{2}{*}{ 蚺 } & \multirow{3}{*}{$\begin{array}{c}\text { 生 } \\
\text { 存 } \\
\text { 日 } \\
\text { 數 }\end{array}$} & \multirow{3}{*}{$\begin{array}{l}\text { 術潛 } \\
\text { 後血 } \\
\text { 大反 } \\
\text { 便㤫 }\end{array}$} & \multirow{3}{*}{$\begin{array}{c}\text { 銝 } \\
\text { 尒 } \\
\text { 使 } \\
\text { 角 } \\
\text { 有 } \\
\text { 热 }\end{array}$} & \multicolumn{2}{|r|}{ 潰 } & \multicolumn{4}{|c|}{ 癔 } & \multicolumn{2}{|l|}{ 糜 } & \multirow{2}{*}{\multicolumn{3}{|c|}{$\begin{array}{l}\text { 淋 } \\
\text { 芭 } \\
\text { 拨 } \\
\text { 胞 }\end{array}$}} \\
\hline & & & & & & & \multirow{2}{*}{ 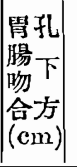 } & \multirow{2}{*}{$\begin{array}{c}\text { 大 } \\
\stackrel{*}{*} \\
(\mathrm{~cm})\end{array}$} & \multirow{2}{*}{\begin{tabular}{|l|} 
形 \\
狀
\end{tabular}} & \multirow{2}{*}{$\begin{array}{l}\text { 窂 } \\
\text { 多 } \\
\text { 有 } \\
\text { 無 }\end{array}$} & \multirow{2}{*}{$\begin{array}{l}\text { 邆 } \\
\text { 緣 } \\
\text { 隆 } \\
\text { 起 }\end{array}$} & \multirow{2}{*}{ 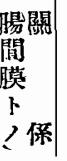 } & \multirow{2}{*}{$\begin{array}{l}\text { 溌 } \\
\text { 生 } \\
\text { 暗 } \\
\text { 位 }\end{array}$} & \multirow{2}{*}{$\begin{array}{l}\dot{\gamma} \\
\dot{y}\end{array}$} & & & \\
\hline & $\begin{array}{l}\text { 香 } \\
\text { 㩆 }\end{array}$ & $\begin{array}{l}\text { 體 } \\
\text { 重 }\end{array}$ & 別 & & & & & & & & & & & & $\begin{array}{l}\text { 部 } \\
\text { 位 }\end{array}$ & 數 & 学 \\
\hline \multirow{2}{*}{ 術 } & 100 & 8.5 & $\hat{o}$ & $18^{\circ}$ & 9 & + & & & & & & & & & 煠腸上部 & 少 & - 中 \\
\hline & 101 & 11.0 & $\hat{\delta}$ & 27 & 14 & + & 2.0 & 2.5 & |圓形 & + & + & - & 空腸上蔀 & 帽針頭一 & 大它二指腸 & 少 & \begin{tabular}{|l} 
中 \\
中
\end{tabular} \\
\hline$\vec{I}$ & 102 & 9.2 & 우 & 40 & \pm & + & & & & & & & & & 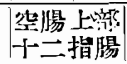 & 少 & 小 \\
\hline A & 103 & 10.5 & $\hat{\delta}$ & 20 & 8 & + & 3.0 & $\times 1$ & 圆形 & - & - & $1-$ & 空腸上 & 义口以下 & 千二指腸 & 少 & 大 \\
\hline
\end{tabular}

()食䬦八初 $\times$ 牛乳, 次二重湯及野荣汁 $\Rightarrow$ 用二

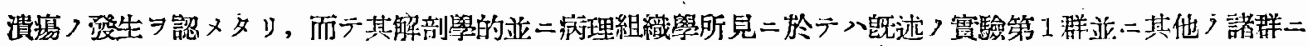

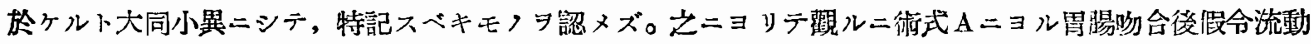

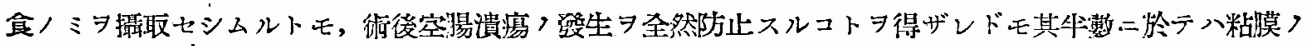

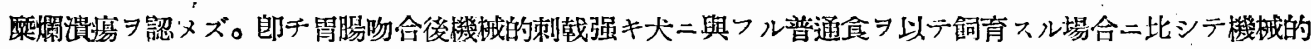

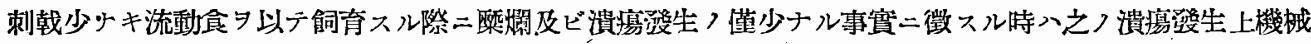
的刺戟ガ可ナリ有力ナル基因ヨナスモ>ト云ハザルベカラズ。

\section{第 9 章 總 括}

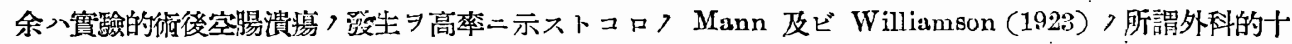

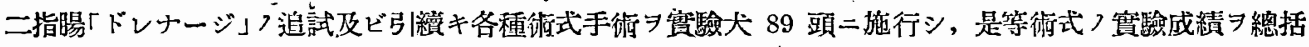

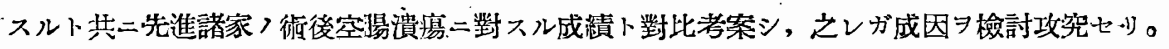

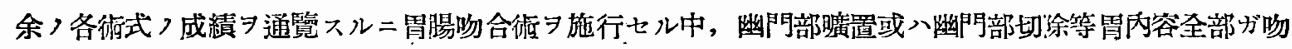

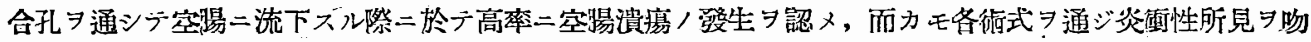

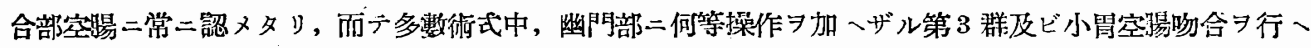

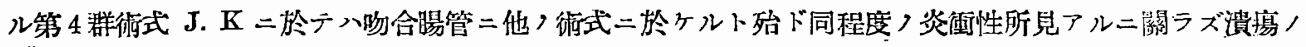

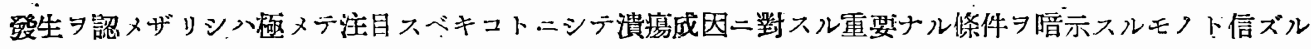
モフナリ。

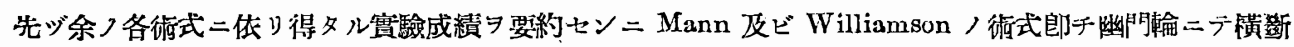

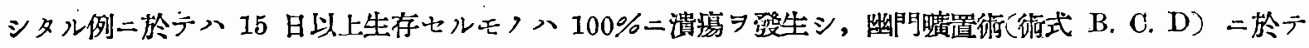




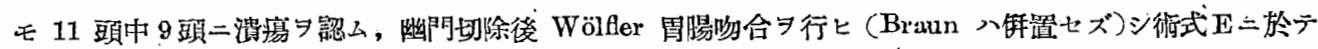

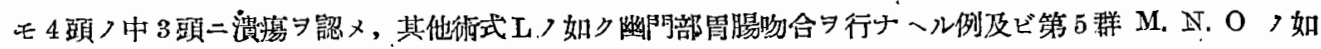

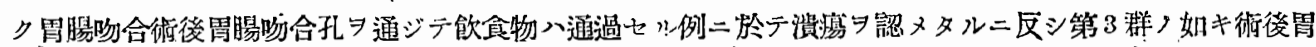

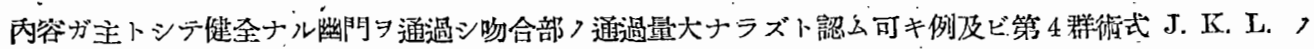

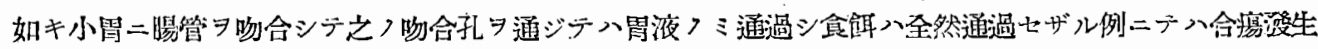

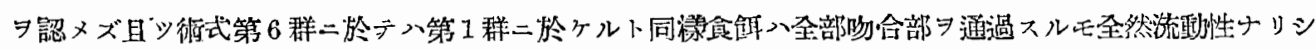

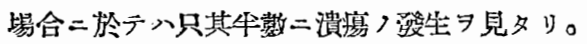

1) 一般榮養状態

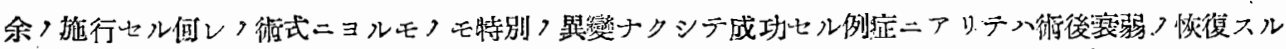

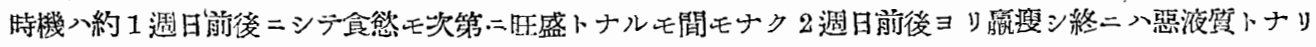

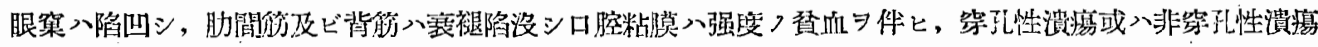

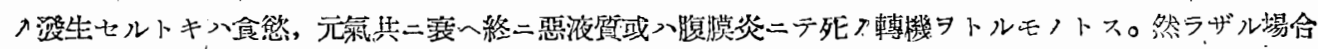

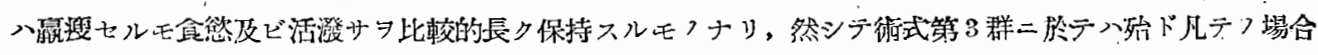

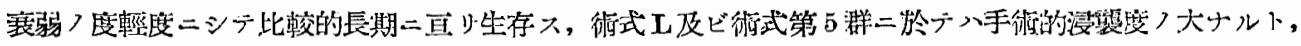

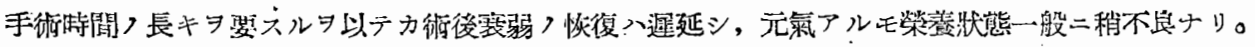

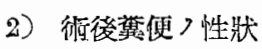

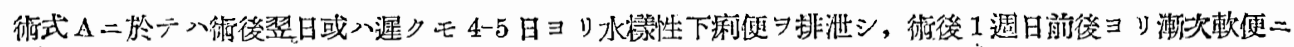
移行シ, 術後 2 週日前後ヨり再ビ下浰便トナり固形便二移行スルコト㱠ドナシ, 之ノ所見入Weiss 及ビ

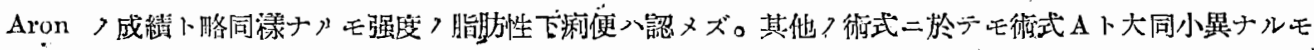

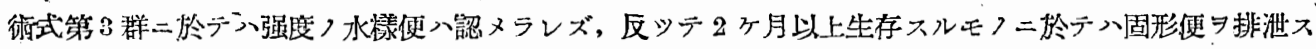

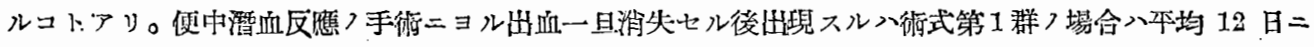
シテ, 第 2 群入平均 10 日, 第 3 群入本均 10 日, 第 4 群入平均 14 日, 參考少式 場合入平均 7 日二シ

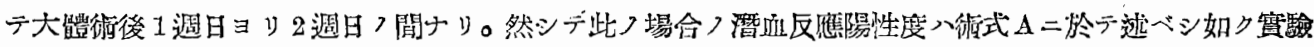

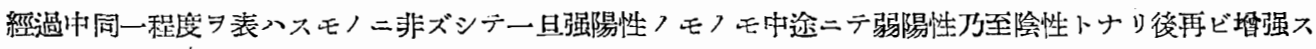

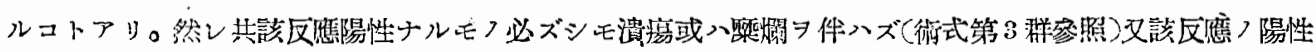

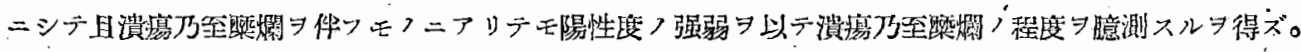

3) 腹陸内所見

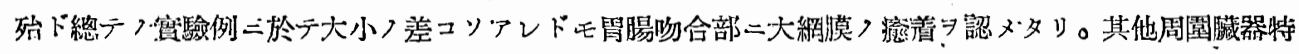

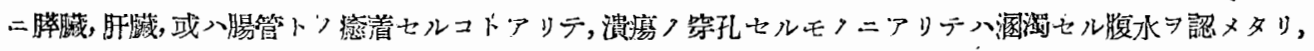

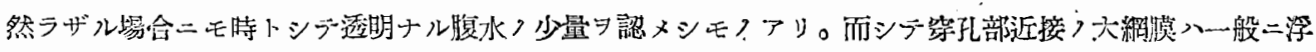

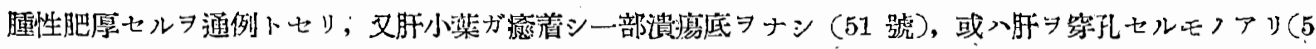

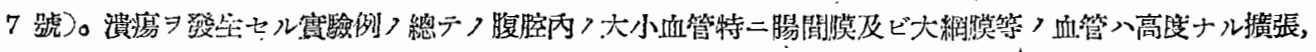

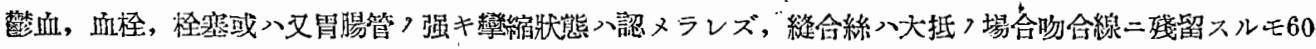

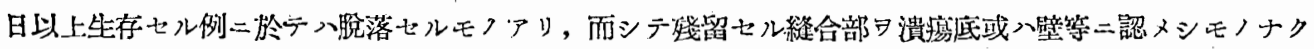

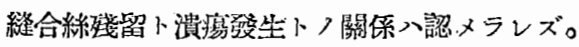

4) 溃 㾤

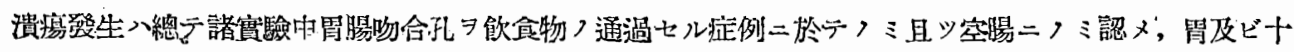

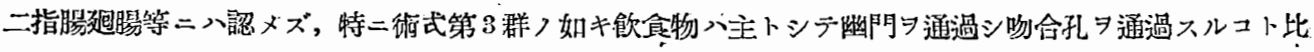

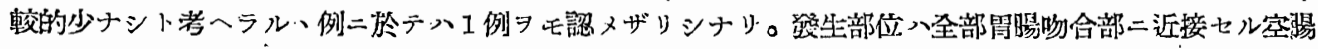

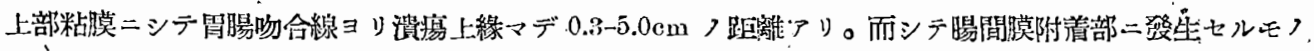

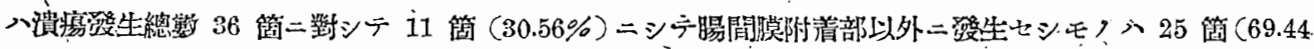

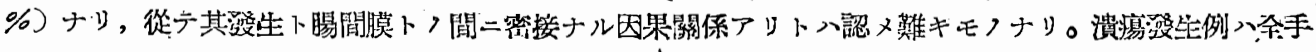




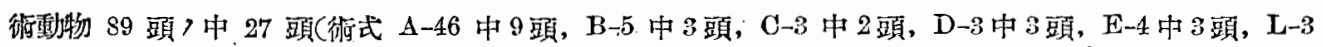

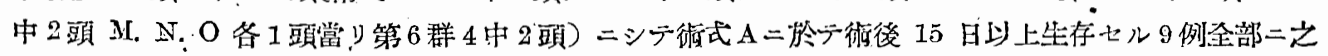

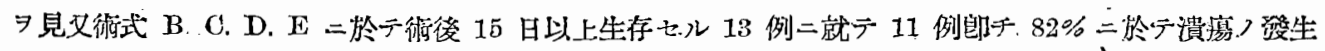

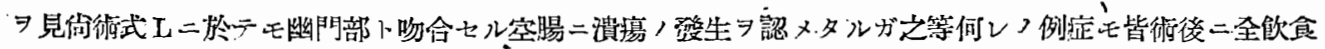

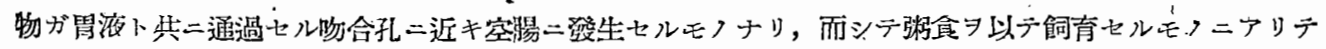

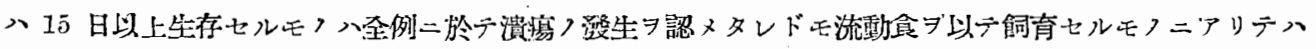

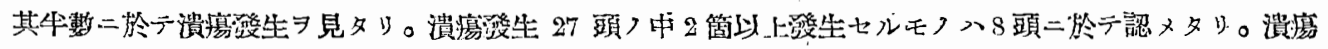
發生動物〉生存日嘍》15-52 日ナリ。

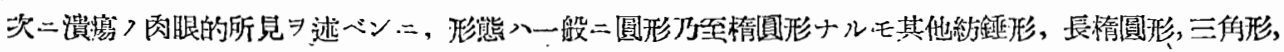
曲王狀等ナリ，周園粘膜下>境界入明瞭ニシテ，周緣入隆起七ルモ，多數アリテ，一般二上緣ハ下線二比

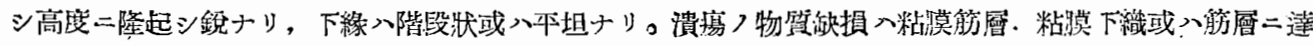

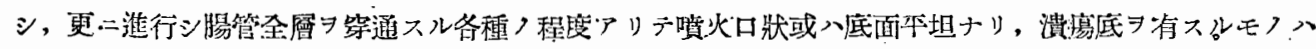

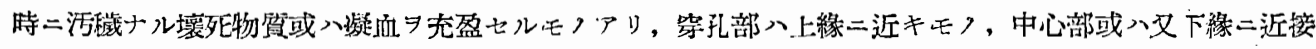
セルモフ等ヨ認メ, 综孔ロノ大キサハ漸ク認メ得ル程度ヨリ小指頭大二至ル各種つモフアリ。

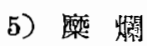

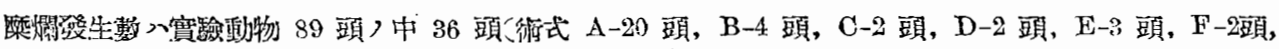

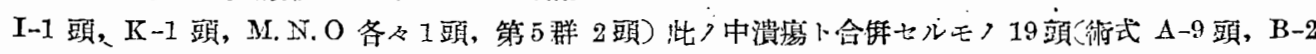

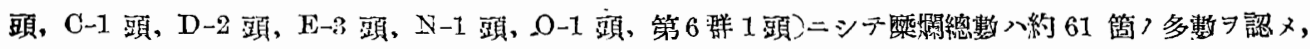

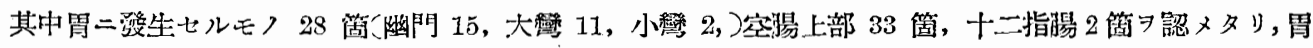

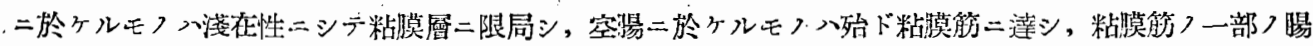

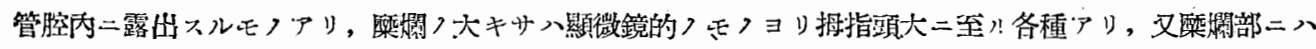

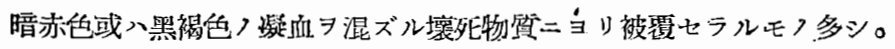

6) 淋已湼胞

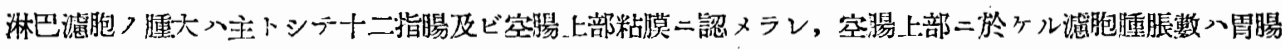

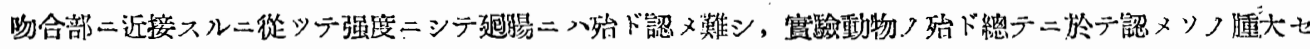

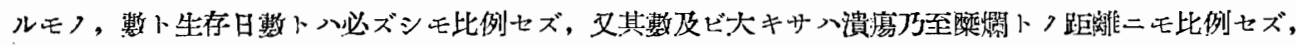

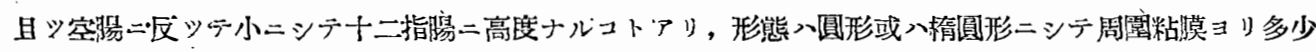

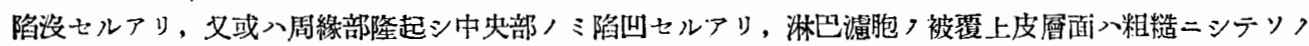

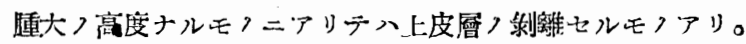

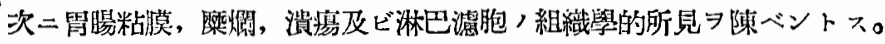

1) 粘膜>所見

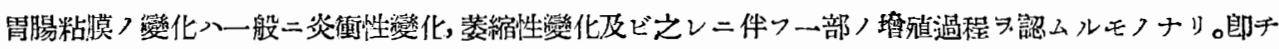

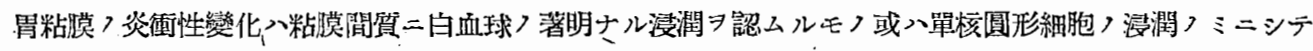

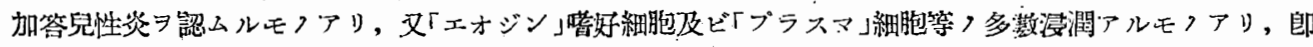

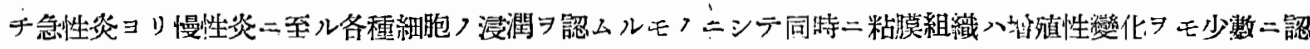

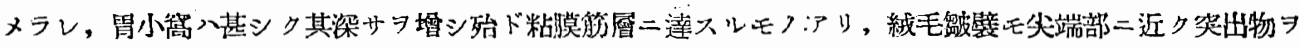

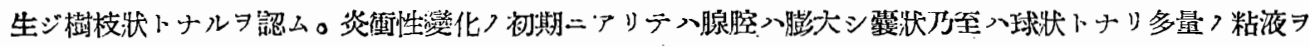

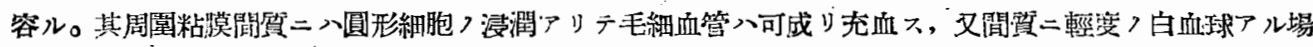

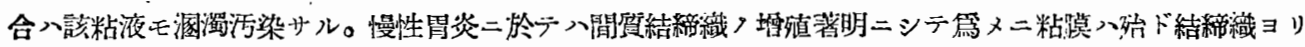

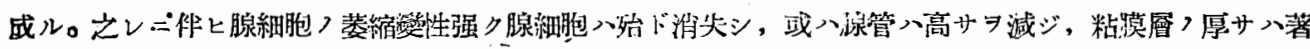
明二菲薄トナル。然シデ炎濞性或ハ又萎縮性過程二於テ腺細胞，中主細胞ガ壁細胞ヨリ遥カ二早期二之等

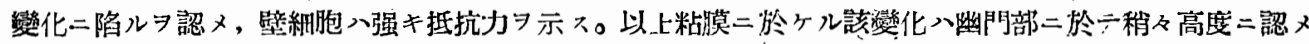




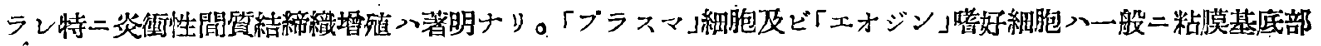

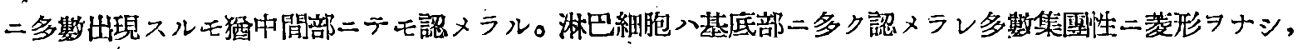

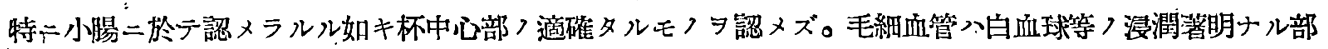

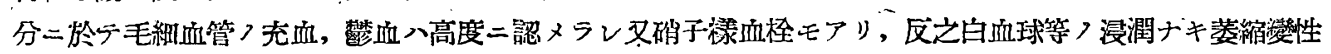
ヨ主トスル部分二於テ 一般二賀血性ナリ。

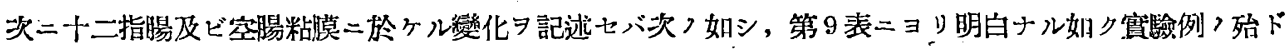

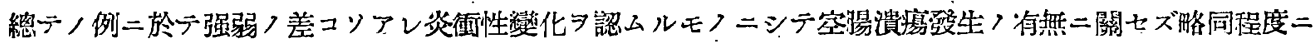
認メラル，而シテ炎婳性變化フ高度ナルハ十二指腸ヨリモ空腸粘膜ニ多數認メラル，特二幽門輸ニテ横斷

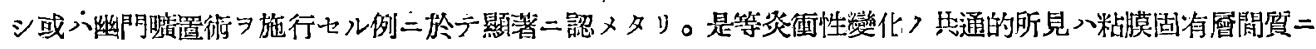

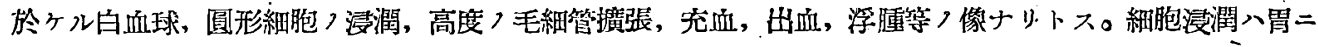

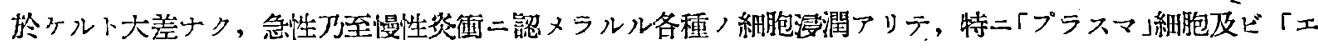

第 10 表 各庄式二於ケル简腸粘膜, 組織學的所見概括

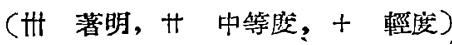

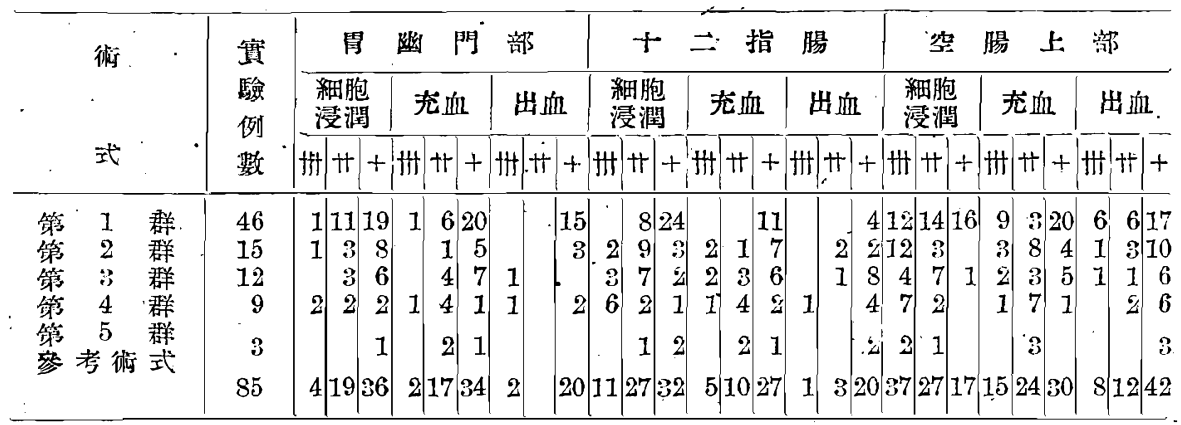

オジン」狫好細胞メ十二指腸粘膜二高度二認メラレ空腸二於テハ殆ド總デ，場合多核白血球及ビ圓形細胞

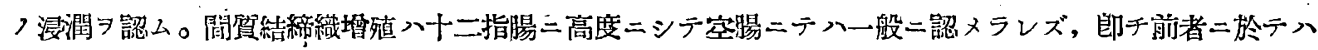

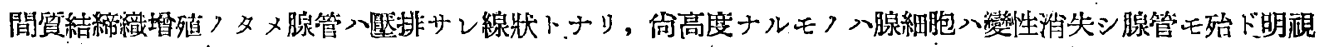

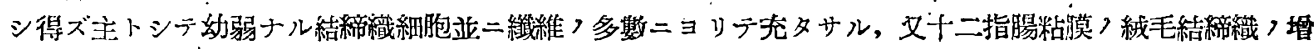

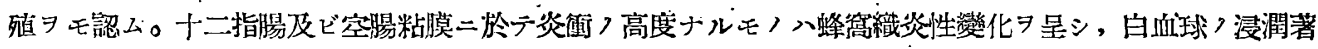

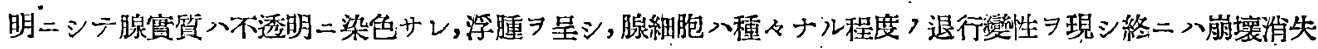

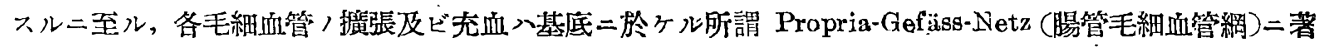

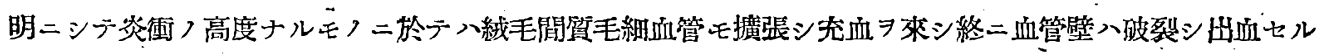

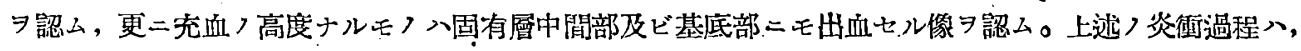

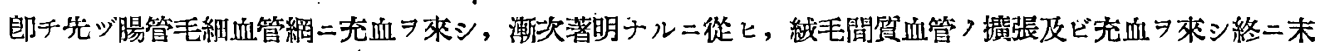
佾部血管，破裂出血シ，進ンデハ粘膜中間層及ビ基底部二モ出血 $ヨ$ 來スニ至ル，而デ初期充血，時期ニ入 圓形細胞ノ浸潤高度ニシテ出血つ時期ニ至レバ白血球浸潤著明ナリ，之二伴七腺細胞入退行變性二陷り不

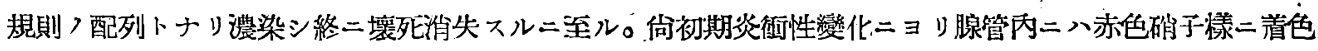

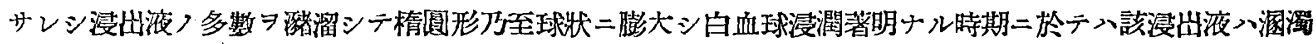
污染サル。

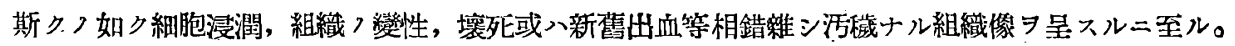

2) 粘膜 下織ニ於ヶル䌯化

各例二共通ナル變化入水腫性變性ニシテ粘膜閒貸ノ充血, 出血及ビ細胞浸潤ノ高度ナル部位二於デ、粘

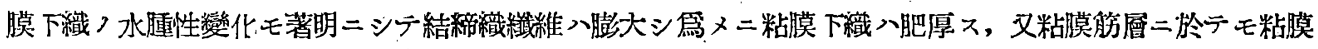

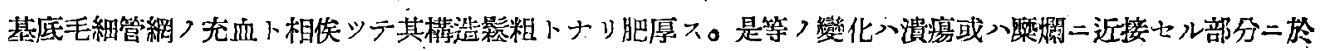




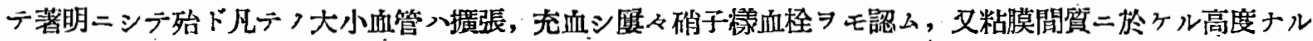

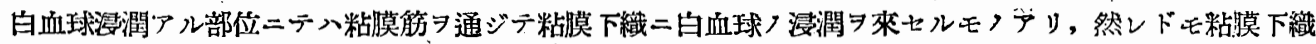
二於ヶル變化》水尰性變化ヨ除キラン粘膜間質つ變化ニ比スレバ著明ナラズ。

3）觔層二於ヶル變化

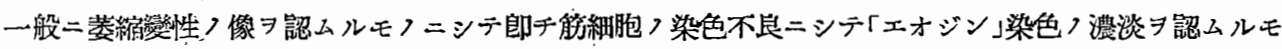

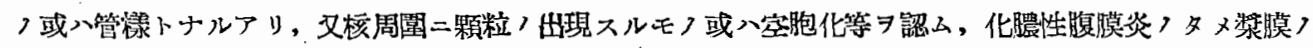

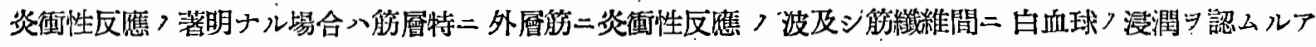
リ。

4）アウェルバツハ氏神經讟 (Plexus Myeritericus 8. Auerbachii) 及ビマイスネル氏神經叢 (Plexus Submucosus s. Meissnerii), 變化

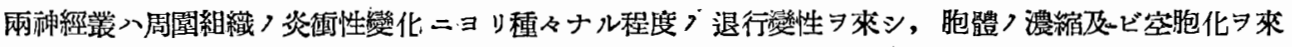

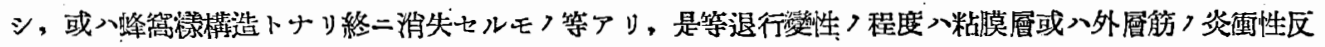

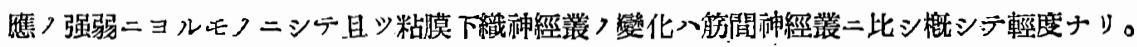

5) 漿膜つ變化

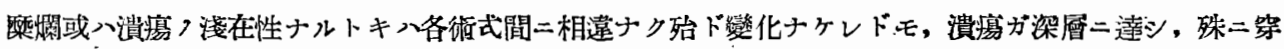

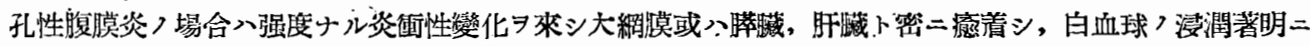

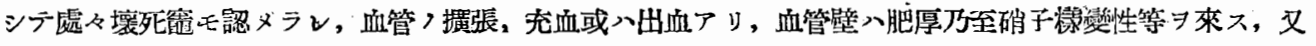

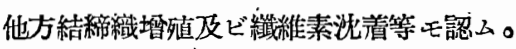

6) 淋巴濾胞了變化

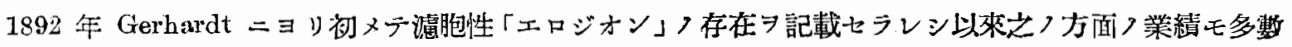

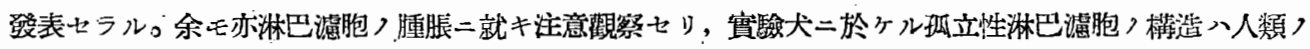
其レト大差ナキコト入各泝究家ノ記述セルトュロニシテ，多クハ西洋梨形 7 呈シ其中心部入淡明ナリ郎チ

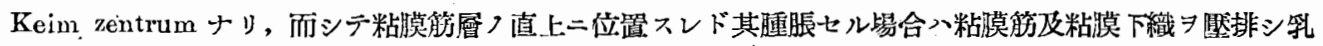

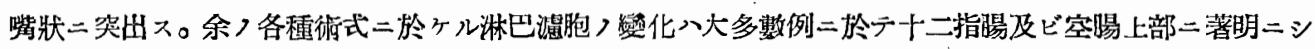
テ前述セル如ク胃ニ於デハ稀レニシテ潣胞中心部ノ淡明ナルモフナク Keim zentrum ト思ボシキ所見ヨ

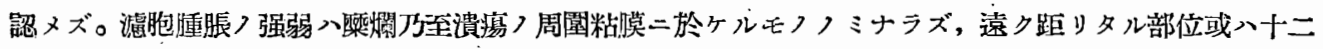

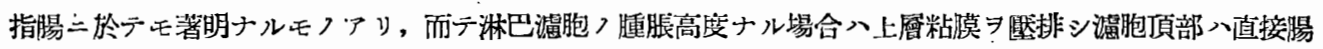

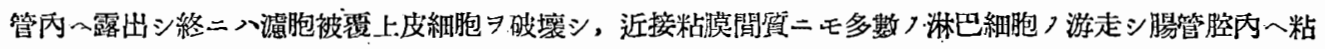

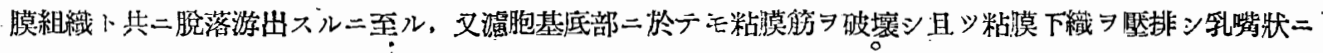

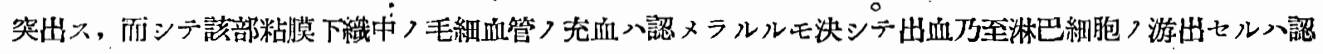
メズ, 叉溜胞周園粘膜入潰葟周園二認メラルル如キ高度ナル炎㣫性變化入認メラレズ, 全實驗犬中唯 1 例

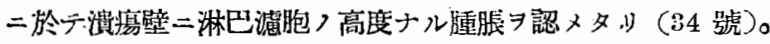

7) 演瘍, 組織學的所見

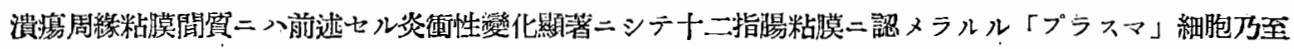
「エオジン」咾好細胞, 出現, 端二再生性修覆性變化極メテ輕微ニシテ新生サレタル上皮細胞ガ粘膜筋, 粘

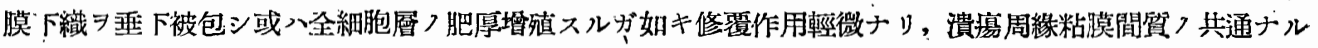
變化入, 粘膜上皮〉壤死脫落, 粘膜間質〉疎開, 腺細胞>退行變性等二シテ是等, 所見入衍後 1 週日後二

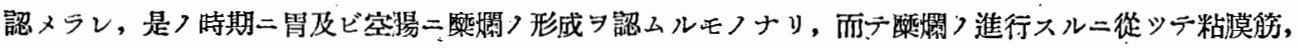

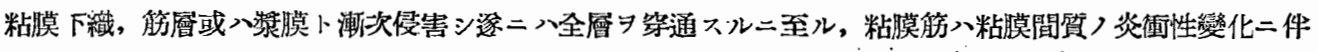

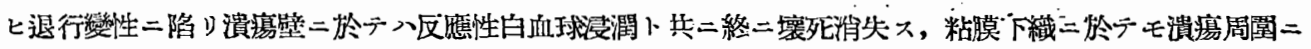

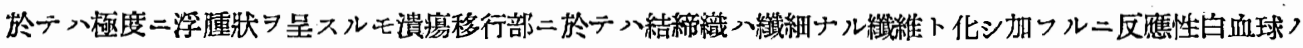

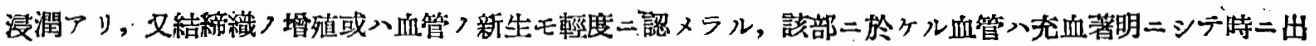




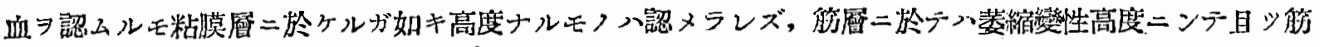

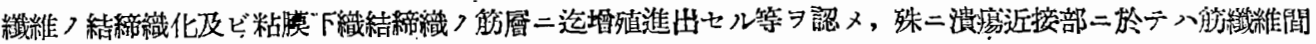

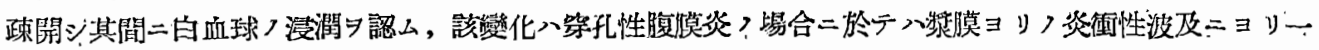

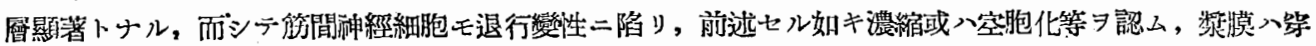

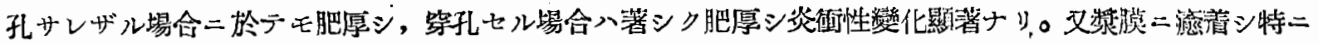
溃湯底 二破壞大。

\section{第 10 章 術後空腸溃原ノ成因二就テノ考察}

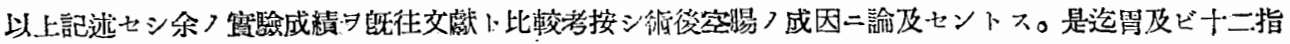

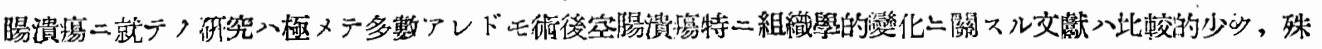
二余，寔驗，如方各種少式二就テ，組織學的俐究入㱠ドナシ。

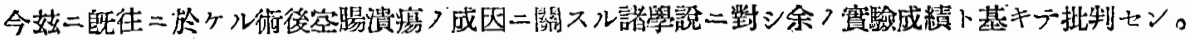

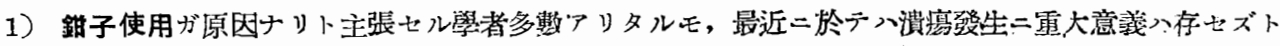

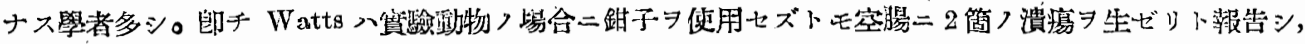

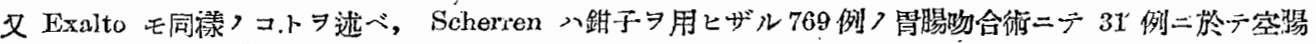

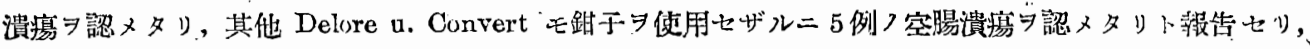

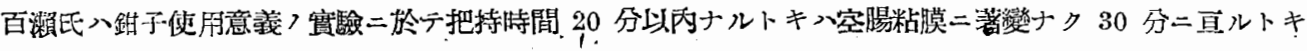

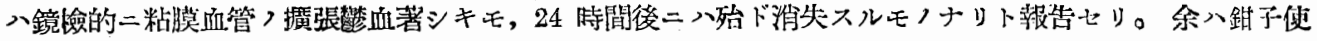

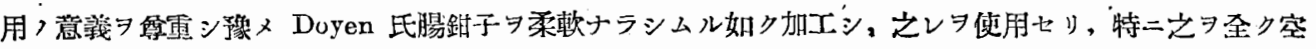

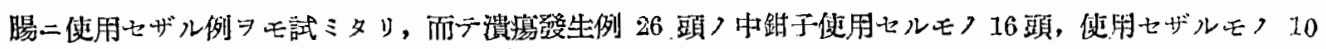

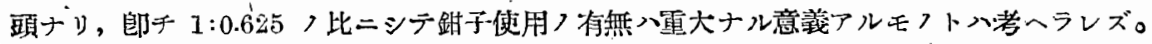

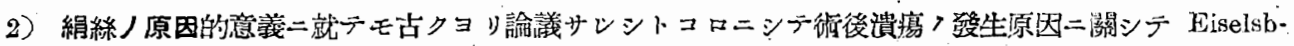
erg 八粘膜縫合，Unterlassen デアルトナシ，Schwarz ハNaht insuffizienz カ, 又八綘合材料ニヨルト

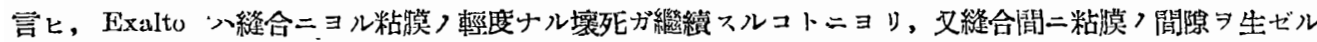

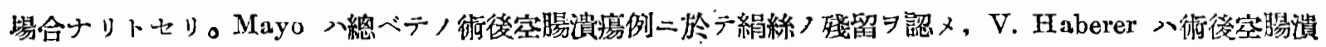

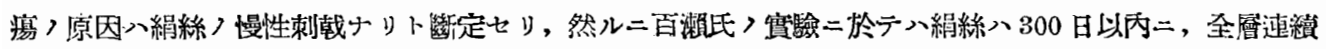

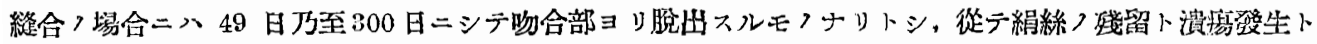

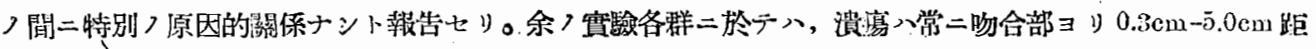

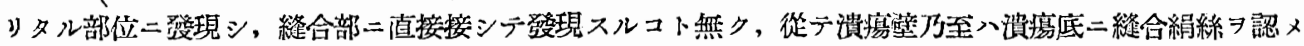

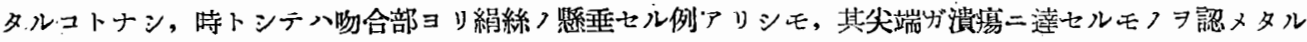

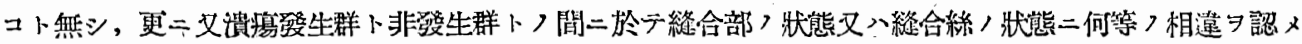

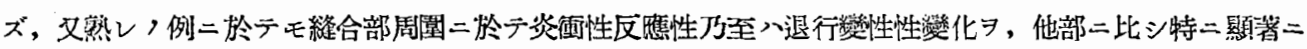

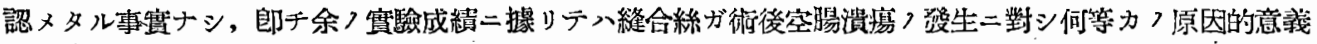
ヨ有スルモ入卜推镖スルニ足ル根據ナシ。

3）、淋巴濾胞卜術後空腸潰瘍ノ關係二就イテモ古來種々〉見解發表セラレタリ, 郎チ 1892 年 Gerhardt

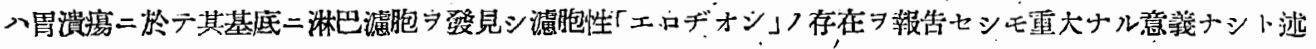

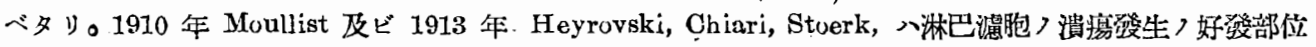
ナリト認メタリ。本邦二デモ舟木, 赤木, 森岡等ノコレニ閶スル舨究アリ, 特二最近森岡分所謂外科的十

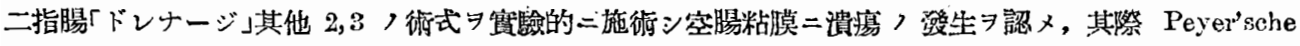

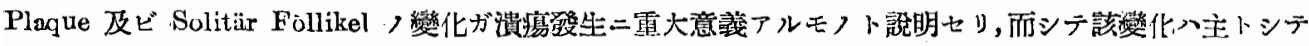

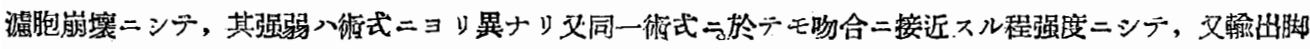

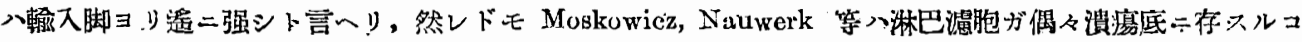




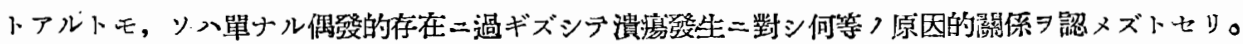

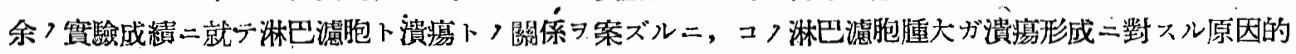

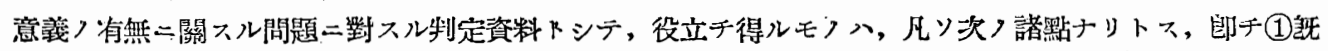
述フ如ク余フ實驗各群二於テ腸殊二空腸壁淋巴濾胞ノ腫大入確實三認メ得ルコトナレドモ, 其程度ガ潰瘍 發生ト, 少クトモコレガ好發部位タル空腸殊二胃吻合近接部二於デ八, 他部二比シ，特二必發性且高度ナ. ルヤ否ヤ, (2)各賽騟群中潰瘍發生アリタルモノト, 然ラザルモノトノ間二濾胞湩大變化ノ有無㷠二其程度

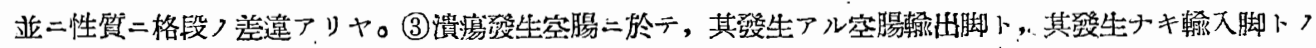
閒二,コレ等ノ點ニ於テ明カナル差違ヨ認メ得ルヤ否ヤ, (4)胃腸物合ガ空腸二於テ施行セラレタル淕合卜

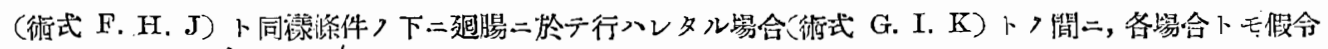

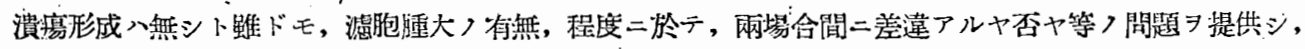
檢討スル必要アリ。而シデ各實騟群ニテ詳述セル如ク, 濾胞腫大, 變化ガ必ズシモ空腸殊二胃吻合近接部 二於テノミ渚明ナリト入言七難ク，十二指腸或八吻合部ヨり遠ク距リタル空腸二於テ其敷, 程度共ニヨリ

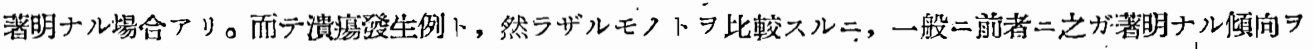

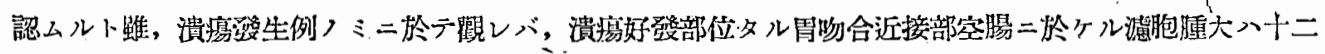
指腸 其レニ比シ同程度ナルカ或ハ十二指腸或入吻合部习遠ク距りタル空腸二之ガ反ッテ高度ナル場合も

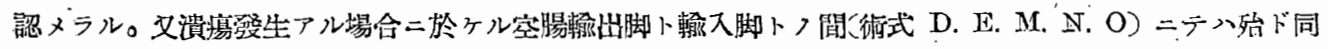

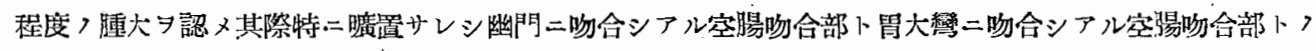

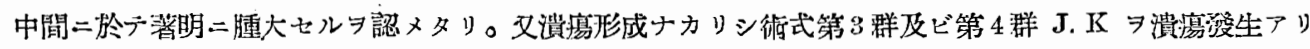
タル其他〉諸群ト比較スルニ第 5 表及ビ第 6 表二示ス如ク备群トモ略々同程度つ腫大アルラ認メタリ。以

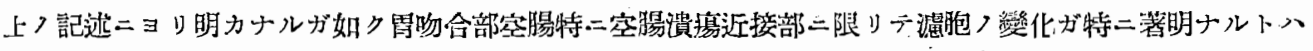

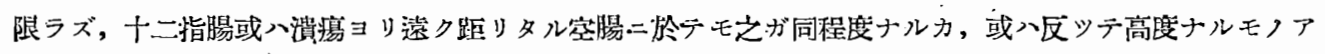
リ, 殊二空腸二於デン之ガ特二高度ニ來ルベキ本來ノ婆約ガ具備スルヤ否ヤタ判定セシムべキ術式第 3 群 及ビ第 4 群 J. K 二於テモ他群卜略々同程度ニ之ヨ認メタルニ過ギザリシ事實ハ, 該變化ガ溞瘍涭生下直

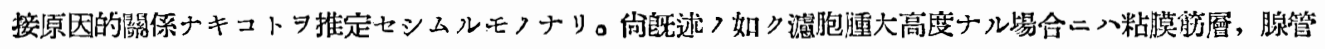

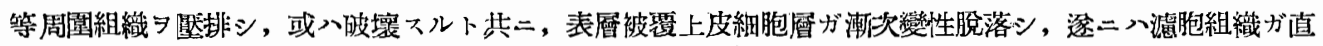

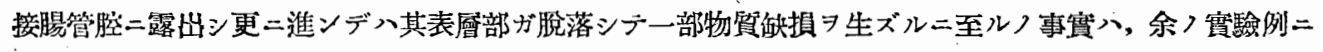

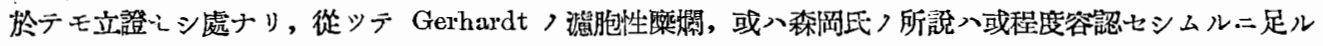

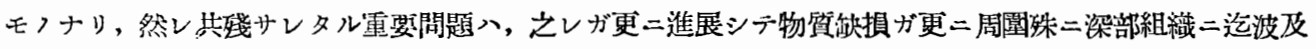

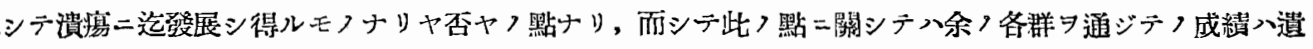

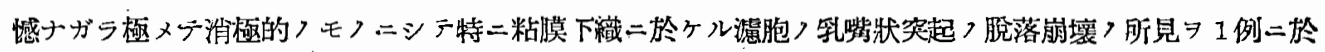
テ認メタル他ハ少クトモ之レタ肯定シ, 主張スルニ足ル根據习立證シ得ザルモノナリ。

上上列擧セシ余, 各種璂驗例二於テ立證シ得タル諸事實, 諸谓係八胃腸吻合術施行ノ結果トシテ, 消化

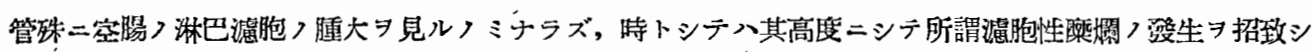

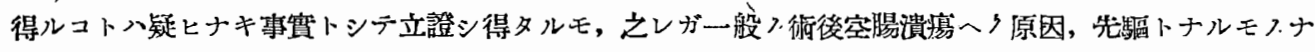

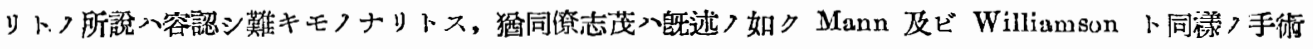
施行犬二於デ, 殆ド, $100 \%$ 空腸潰瘍, 發現习認メ且淋巴濾胞, 腫大ヨ證明シタルニ抱ラズ後者ガ前者, 原因ヨナスト推定ズル何等ノ組織學的所見ヨモ證明シ得ザリキ。

4）術後空腸潰瘍發生卜神經說, 本學說八古來多盙ノ學者ニヨリデ唱導セラレタリ。1841 年所謂 Gas-

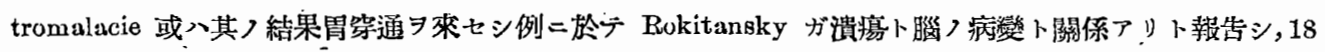

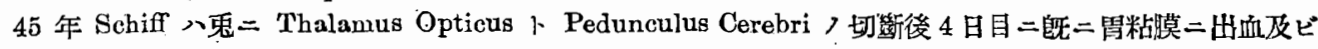

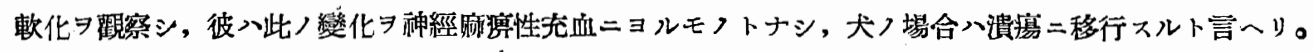

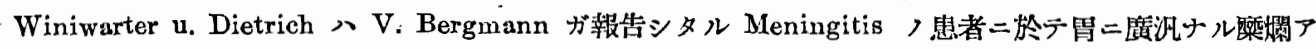


リシヨ報告セリ。V. Bergmann 自身モ術後空腸潰瘍入神經性刺戟二因ル榮養障礙ノ結果ナリト言へリ，

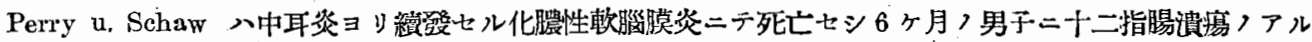
ヨ報告七り。Gunzberg 八兩側ノ迷走神經ノ切断ニヨリ胃液酸度ガ數時間後二强り高メラレ, 胃壁入溶解

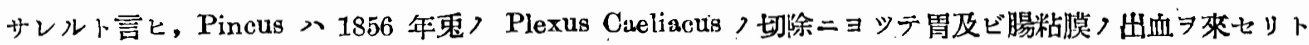

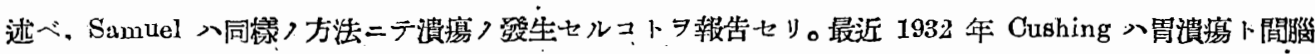

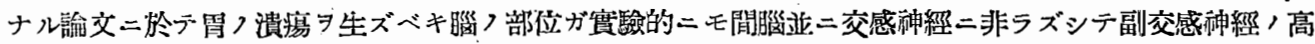
位中樞部ニアリトシ，殊二其刺载ニヨルモフナリト報告シデ, 以來此方面ノ注意ヨ一段ト惹キタリ，而云彼

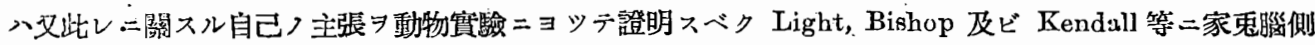

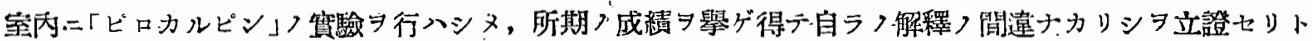
報告七リ。

本邦ニ於テモ中田及ビ田中兩氏入是， Light, Bishop 及ビ Rendall >實驗ニ對シデ追試窧驗セル結果

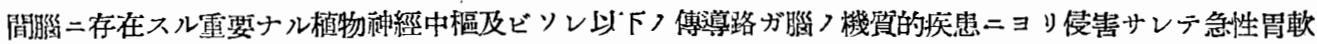
化，血行障礙，分泌及ビ運動障害ヨ來シ，逐二胃二慢性潰瘍ヨ形成スル場合ナシトセズト言へリ。文東及

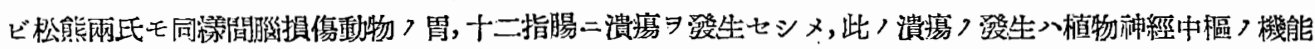

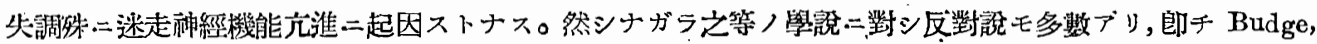
Adrian, Lustig, Peiper, Lander-Bruntun, Marassini, Licini, Enderlen.等モPincus ノ䞄驗ヨ追試シ胃

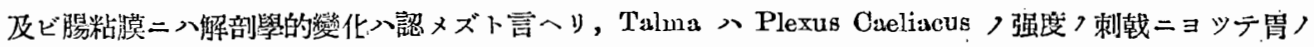

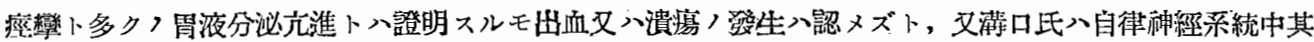

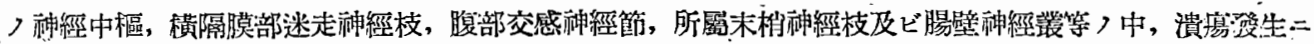

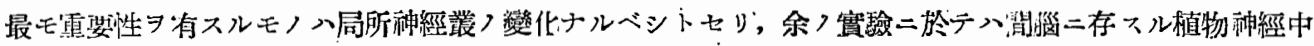

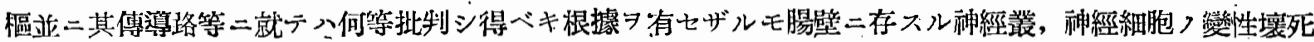

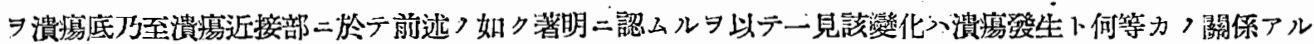

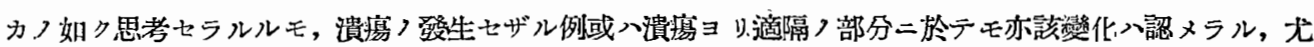

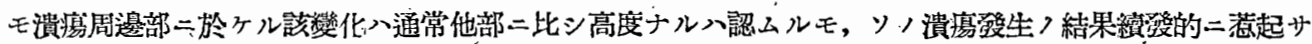

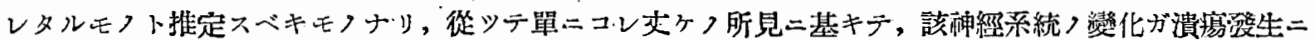

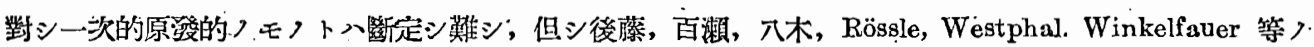

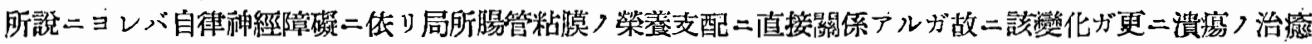
乃至經過 遷延セシムルコトハ可能ノコトナルベシ。

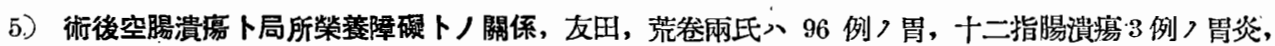

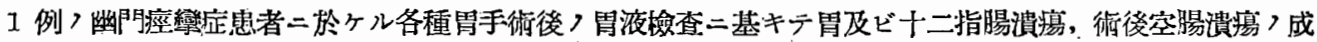

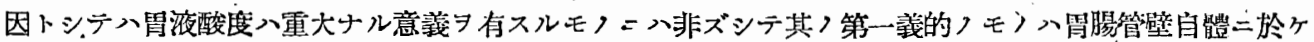

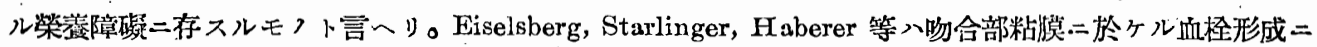

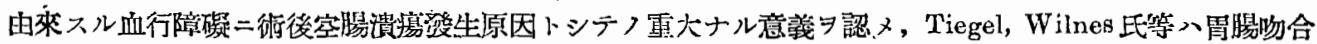
時二腸閴膜

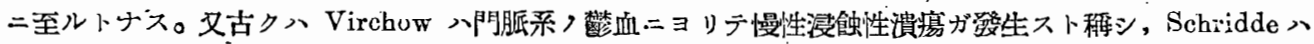

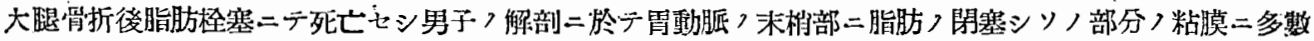

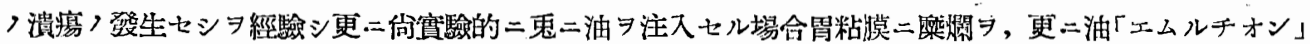

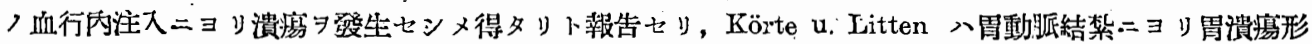

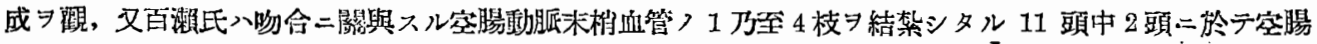

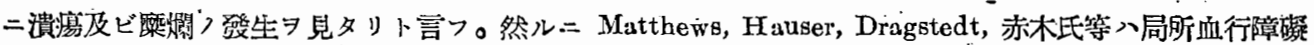

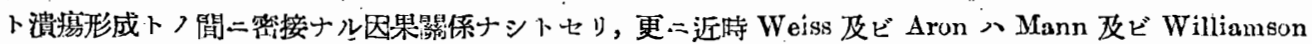

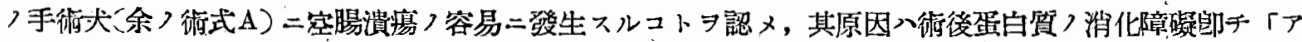




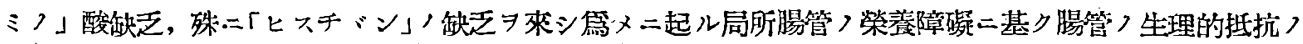

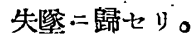

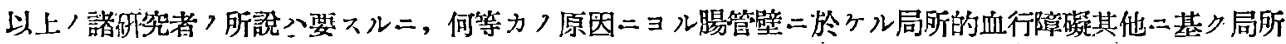

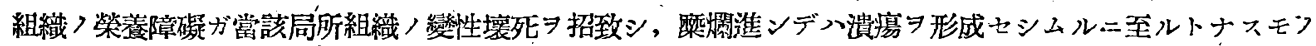

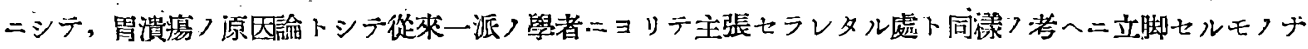
リ，而シテコレ等特殊つ人工的僺作ニヨリテ局所血行ヨ甚シク阻害スル特ハ, 斯クフ如キ結果ヨ招致シ得

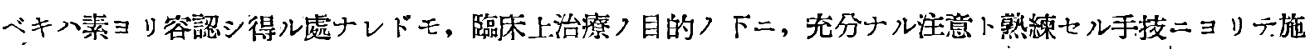

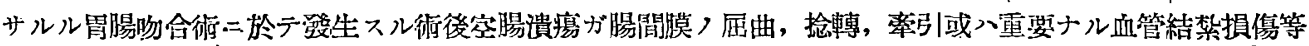

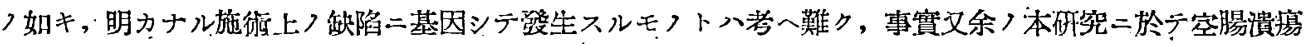

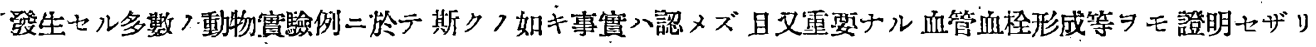

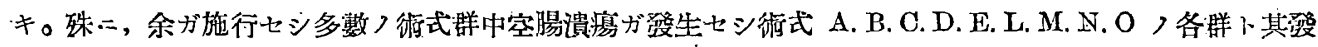

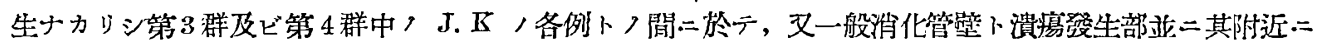

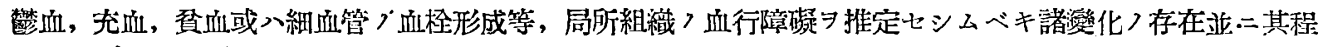
度, 性質:於テ, 何等明カナル相違习證明シ難ク, 且, 空腸並:二一般消化管つ粘膜並ニソレ以下, 組織,

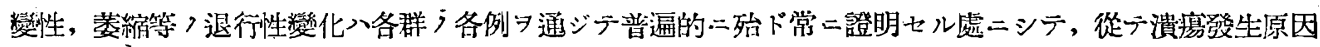
ヨ或一局所ノ血行障礙二歸シ難キモノナルコト入容易ニ了解シ得ル處ナリ。

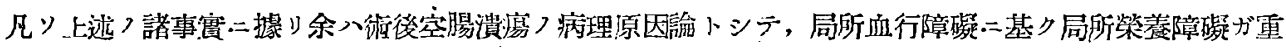
大ナル意義, 貲値习有スルモフナリト入認又難キモフナリト信ズ。

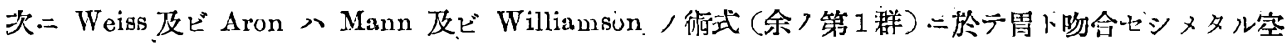

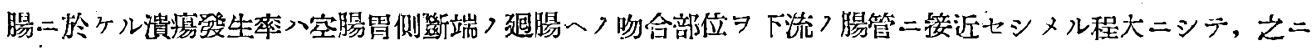
反シ，上流ニスル程小ナリト，成續二準據シテ，該吻合ガ下流ナル程腸內食邻ノ消化吸收ガ障礙セラン，

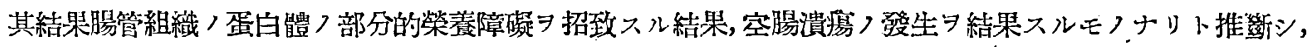

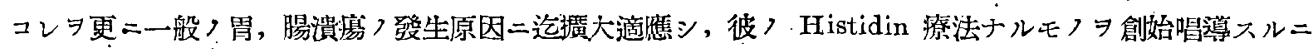
至りシモノナリ。而テ當研究室二於ケル志茂ノ例究二於テモ亦該吻合部位ガ上流ナル程空腸嘳瘍發生率ガ

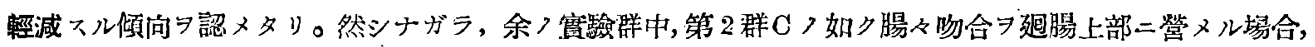
殊: $\mathrm{E}$ 及ビ第 4 群 $\mathrm{L}$, >如ク十二指腸夜 $习$ 胃吻合空腸二直接流入セシメタル埸合:於テスラ, 腸々吻合

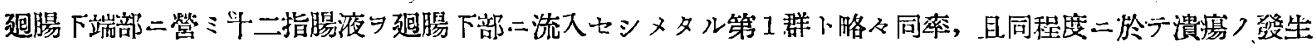
ヨ認メタル事實ニ據りテ，Weiss 及ビ Aron 兩氏ノ主張スルガ如ク消化管潰㿇つ原因ガ十二指腸液流入 部ノ如何ニヨル蛋白體，部分的策養障礙ト言フガ如キモノ二存セザルコトヨ略推定シ得ルモフナリ。而シ

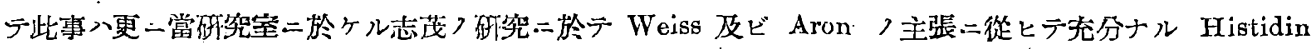

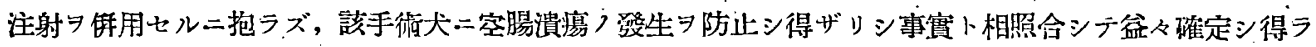
ルル處ナリ。

6）酸性胃液卜術後空腸㿉癔卜う關係, 胃液つ作用, 意義二就デ既二 1828 年 Cruveilheir 八胃, 十

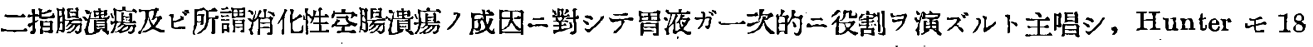
世紀後本二於テ胃液つ刺戟ニヨリ胃ニ呀孔ヨ生ズト言ヒ, 1882 年 Quinke ガ消化性潰瘍ナル名稱ヨ提唱

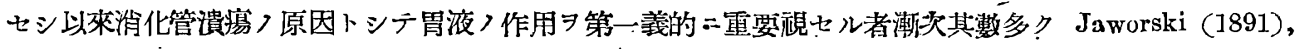

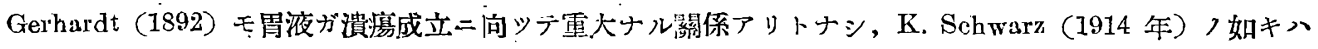
Ohne swueren Magensaft kein peptisches Geschwür ト主㲀七り, Urritia (1927) 八胃液が晹壁二直接

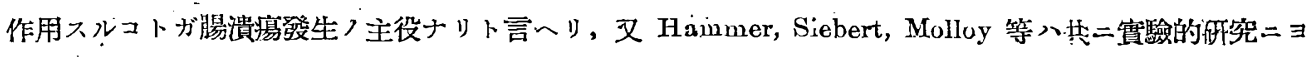

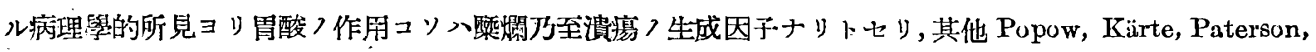
Kummell, Noetzel, Dervaux; Finsterer, Arthen, Boas 赤木, 剛等同泶〉主張見解习探レル研究者八多數

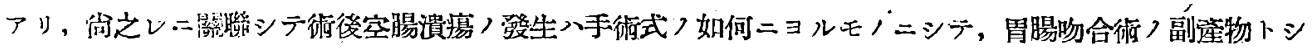




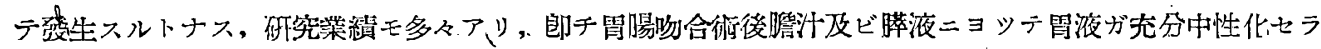

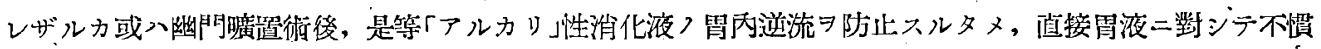

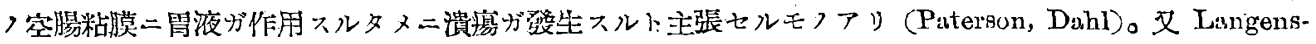

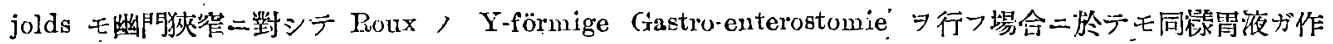

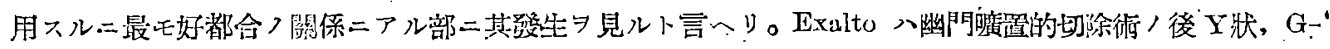

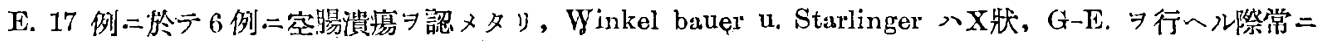

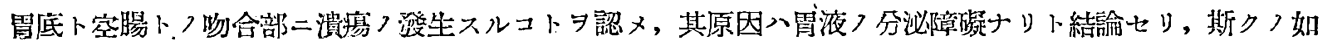

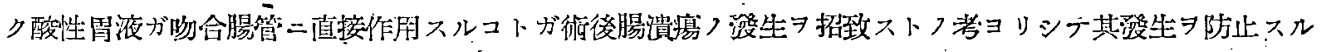

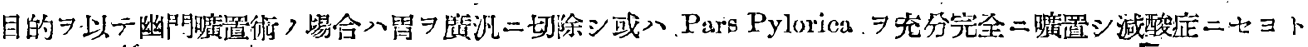

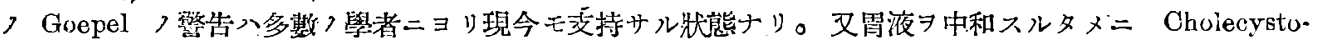
Gastro-Stomie ヨ推獎スル學沓モアリ (Bogoras, Schwarz, Nasarov) 此>他十二指腸液, 周酸中和不全

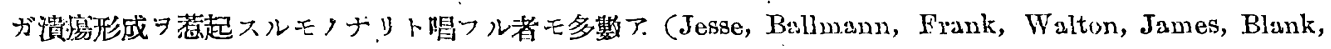
Backy, Michuel) 等々)。

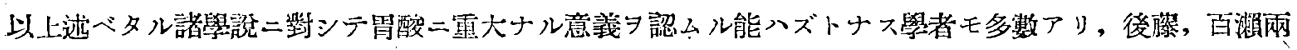

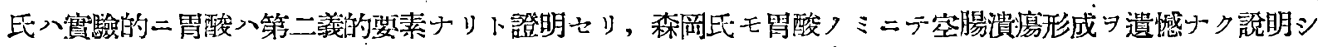
得ル能ハズト言ヒ, Fiori, 川柯上ハ胃壁二八生理的二Ántipepsin つ存在习確メ, .Chiari モ同隐二腸壁二

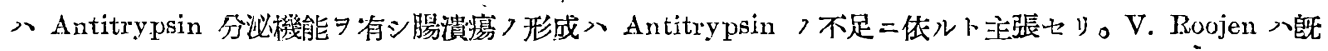

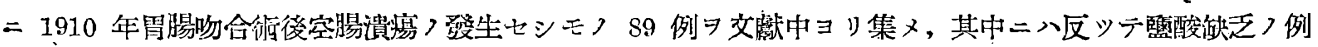
アルヨ觀察シ，胃液フ作用习原因トスル論據ヨ把揘シ得ザリシト。叉 Nyström Junnar 及ビ Philipowicz

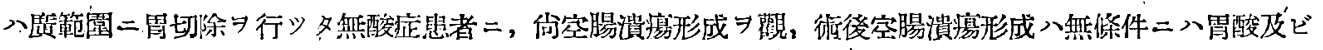
「ペプシン」フ作用ノ結果ナリト斷ズルヨ得ズトシ, Judd, Starr, Horner 等玉同愫ノコトヨ翢告セリ。又

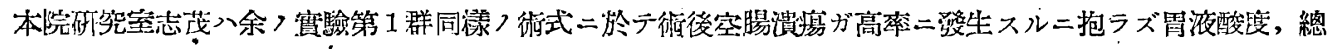

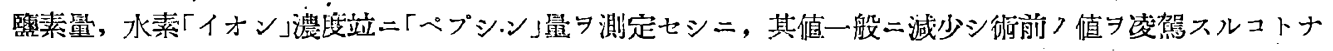
シト钸斷セり。

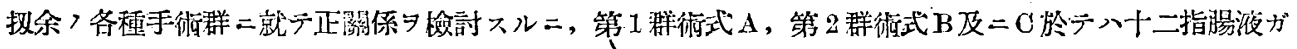

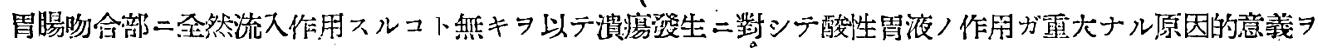

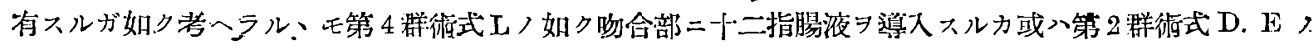

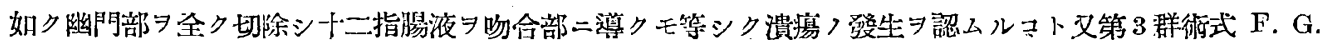

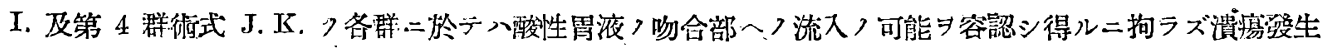

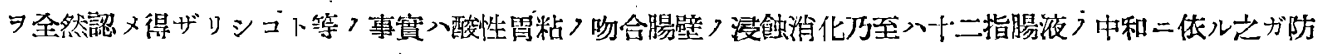

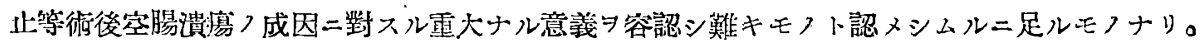

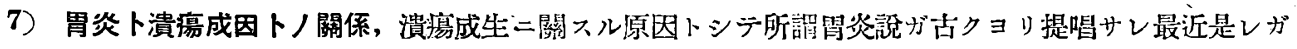
「レントゲン檢查及ビ胃鏡つ使用ニヨリ盆々助成サレ種々的究サレ今日二至レリ。Starlinger 入炎定习伴

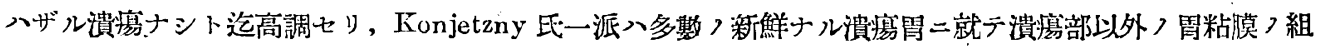

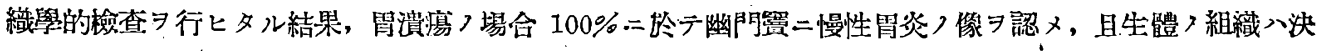

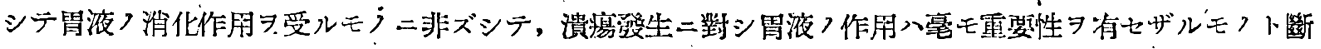
定シ, 從ッデ消化性潰瘍ナル名稱ヨ排斥スベキモノナリ卜强調セリ。勝屋及ビ山田兩氐ハ十二指腸潰瘍二

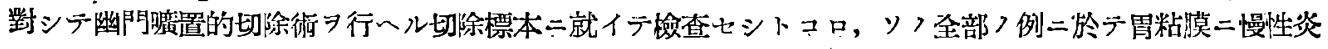

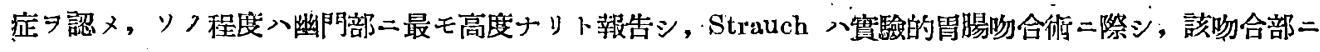

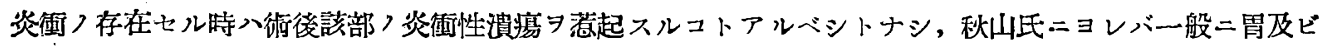

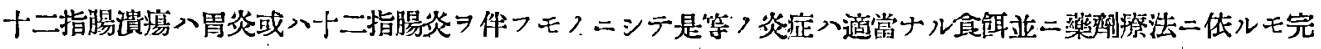

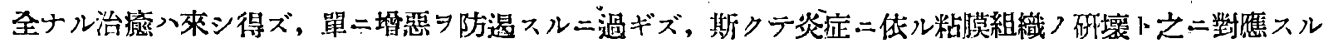




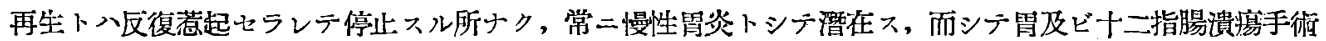

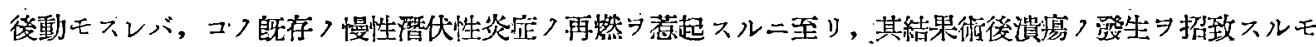

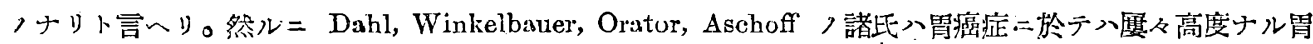

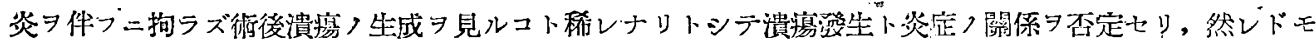

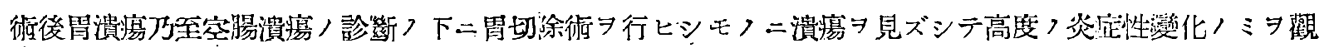

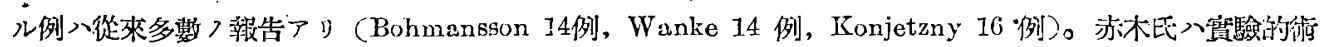

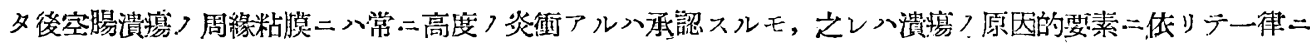

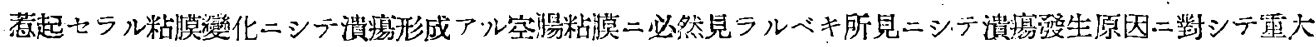
ナル鰔係ナキモノトセり。

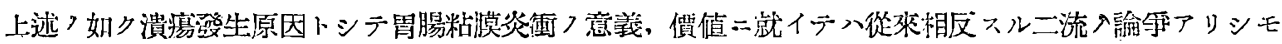
派時之习重要視ス儿傾问アリ。

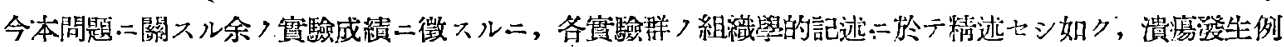

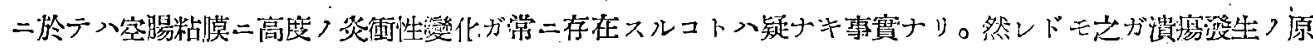

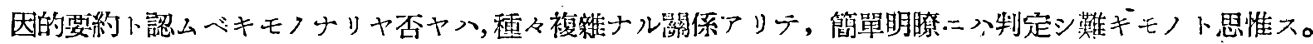

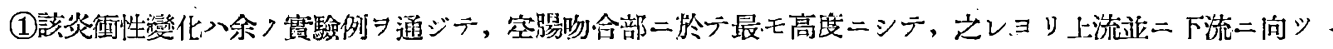

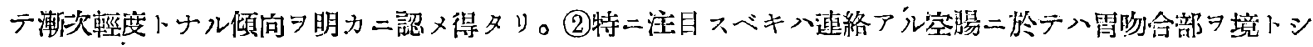

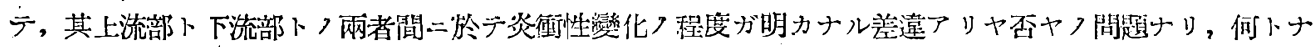

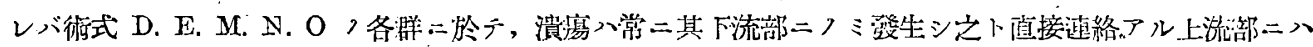

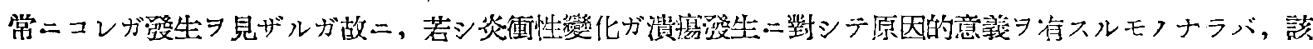
變化入常ニ下流部ニフミ强度二存在シテ上流部ニハ存在セザルカ叉ハ假令存在スルモ格段二輕徽二止ル筈

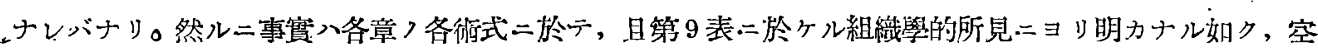

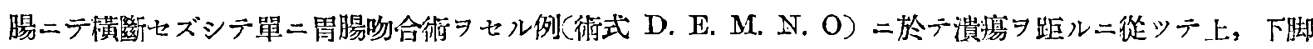

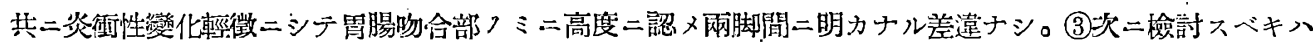

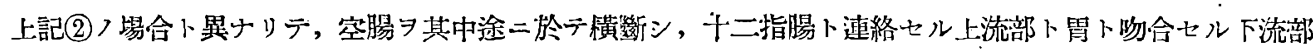

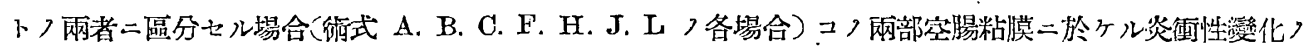

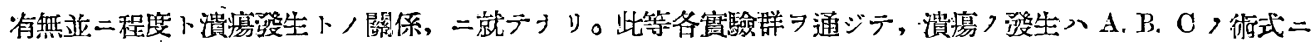

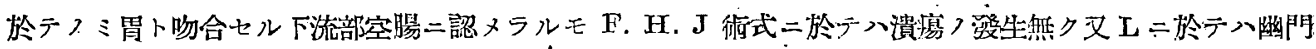

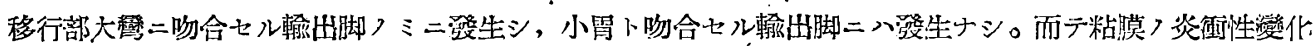

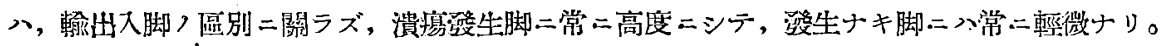

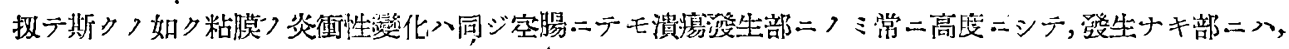

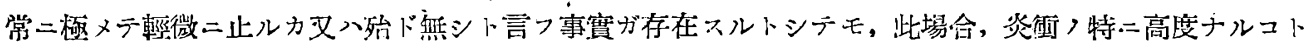

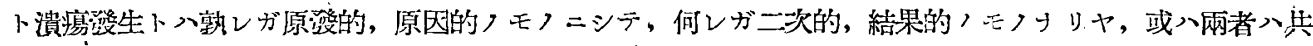

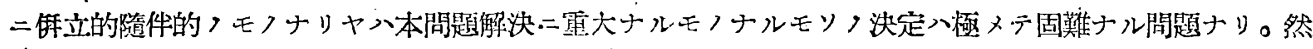

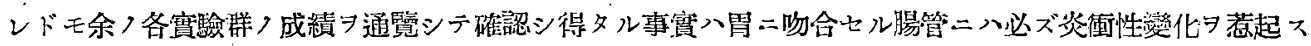

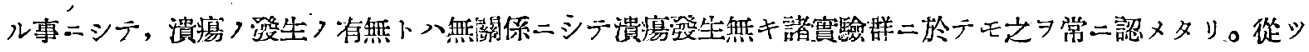

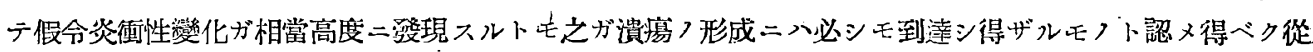

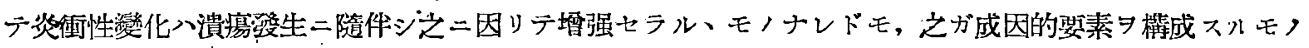
ナリト入認メ灘キモアナリ。

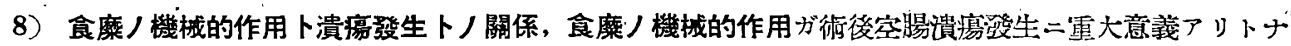

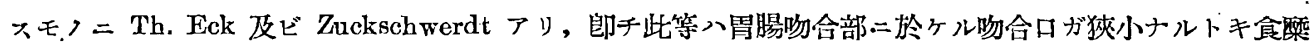

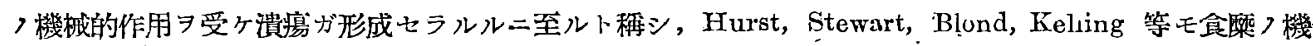
棧的作用习重要峴它り，然レ共他方。von Haberer, Chiari 八臨林的二又 Matthews, Warren 等入實騟的 
研究ニョリラ゙レン反對セリ。

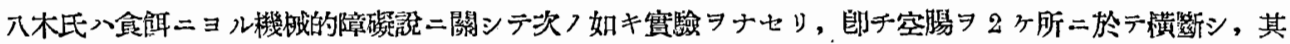

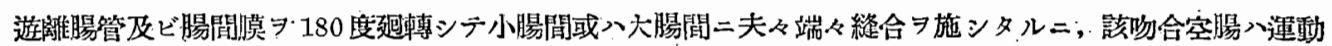

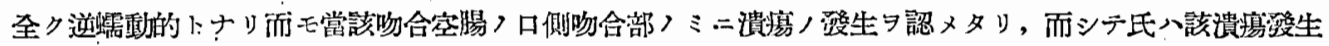

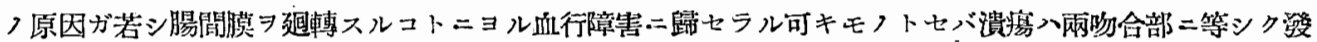

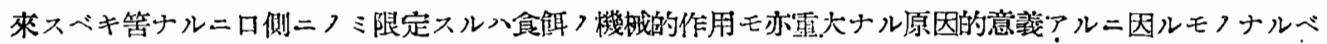

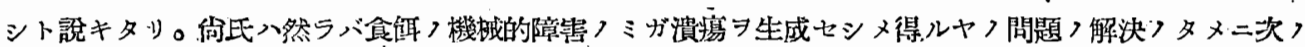

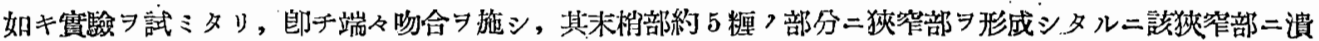

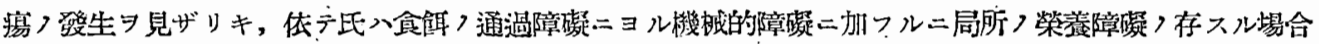
二於テ签易二潰瘍习潑生スルモフナリ下結論セリ。

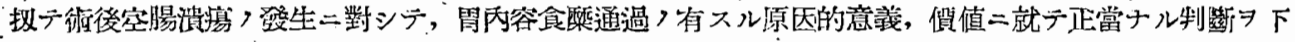

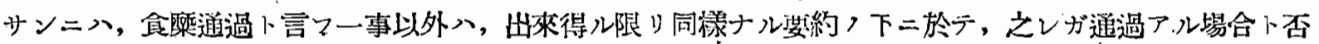

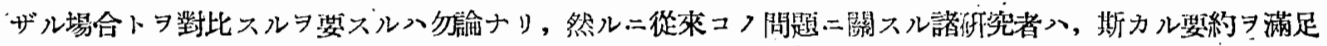

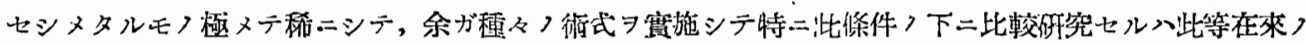

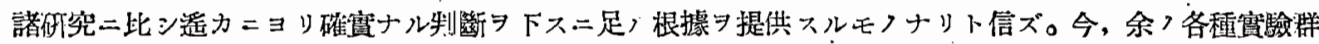

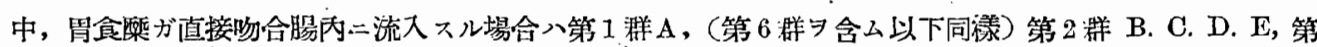

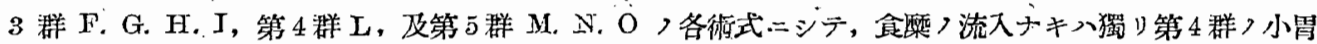

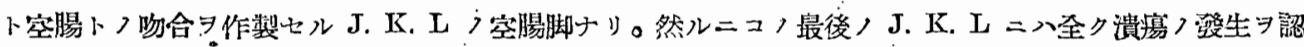

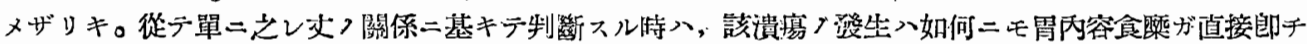
幽門; 十二指腸ヨ經ルコト無シニ流入スルコトニ電管ナル原因ガ存在スルモ.〉推定シ得ルガ如シ，然レ

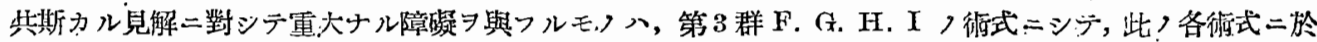

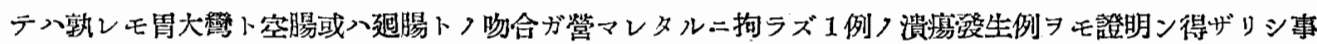
實アリ。茲二本問題/解決二對シテ重大ナル不明ノ謎染浲在シアルモうト斷ゼザル可カラズ，果シデ然ラ

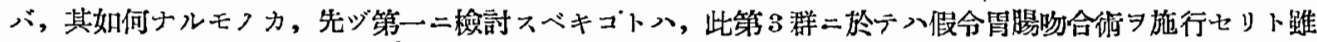

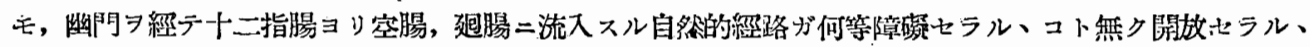

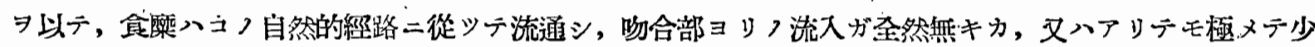
量つセノニシテ，問題トスルニ足ラザルモフ二非ラザルカフ疑問ナリ，而シテ斯ノ如キ考へ八腸々吻合，

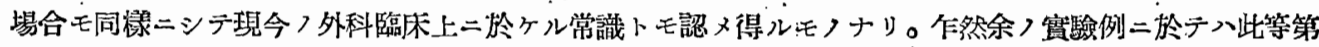

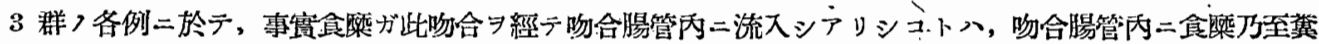

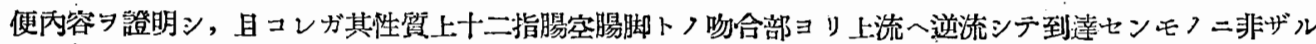
コトヨ確實ニ立證シ得ダルコトニ依り疑ヒナシ，但シコレガ幽門十二指腸习經ル自然路ニ比ン少量ニシテ

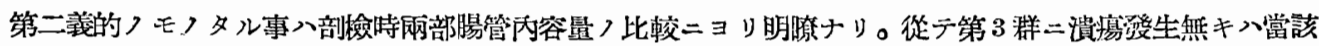
吻合腸管內二胃內签？流入アリトモ其量極少量ナル事實卜或珵度う因果關係アルモノト推定シ得ベシ。

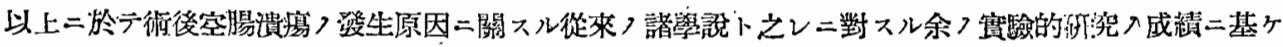
儿批制, 見解〉大略 $习$ 記述セり。

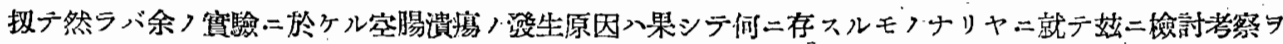

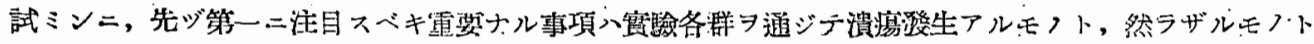

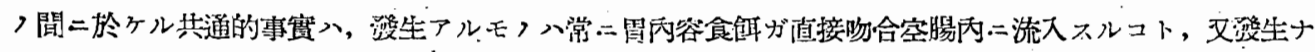

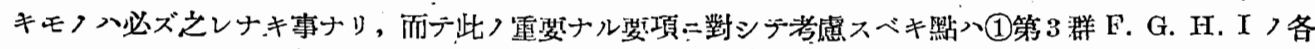

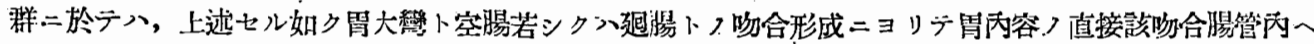

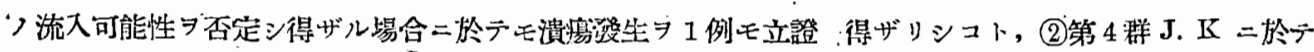

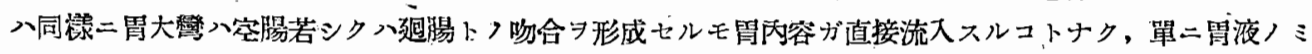




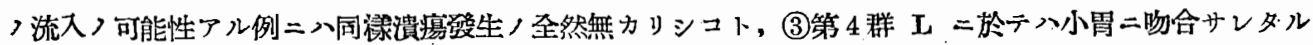
空腸內二八直接胃夜：ミ流入スルモ潰愓發生ナク，之二反シ同一犬二於テ胃幽門部近ク二於テ吻合サン食

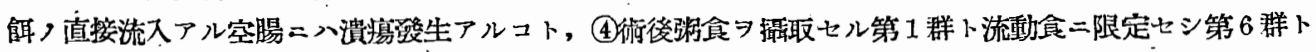

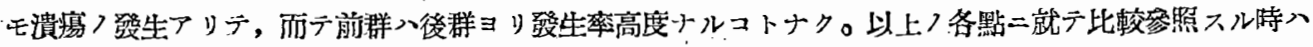
次ノ諸事項ヨ確實二断定シ得ルモつナリト信ズ。郎千

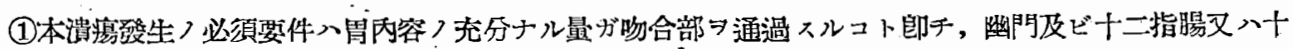
二指腸ヨ通過スル自然的經路シ經ズシテ,胃ョリ吻合部ぎ經テ直接吻合腸管内二充分量流入スルコトナリ。

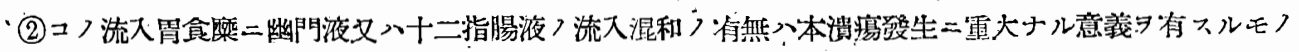
二非ズ, 何トナレバ幽門夜了流入ガ充分ナリ卜認定シ得ベキ各群モ, 之レガ全然缺如スル第 2 群 $\mathrm{E}$ 及ビ 其他つ群モ略同率, 同程度〉溃瘍發生习立證シ得タルタ以テナリ。

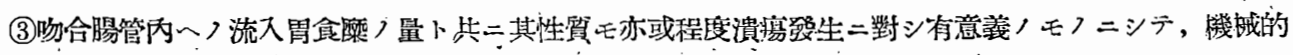
刺戟ノ大ナルモフハ否ザルモフョリモ發生セシメ易シ。

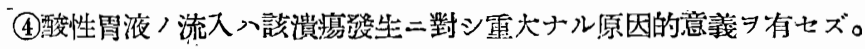

\section{第 11 章 結 、論}

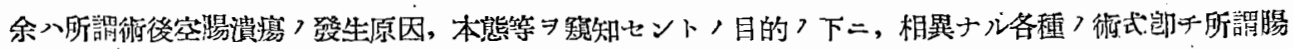

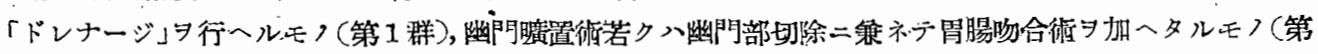

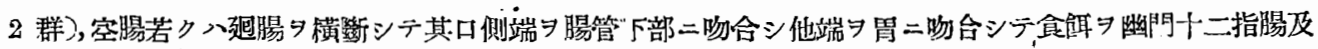

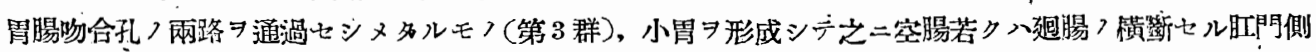

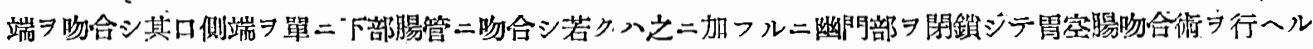

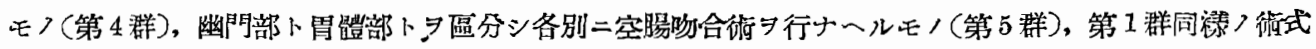

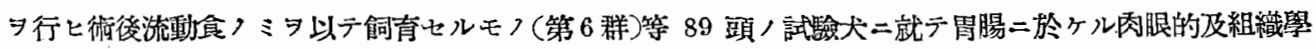

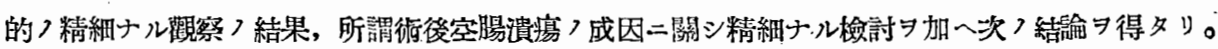

1）Weiss 及ビ Alon 兩氏，外科的十二指腸「ドレナージ」ヨ犬二施行シ胃液卜共二全飲食物习胃腸吻合 孔ヨ通過セシメタルニ, 術後 15 日以上生存シタルモつニ於テ八其全例二所謂術後空腸涄瘍う發生ヨ認メ タリ。

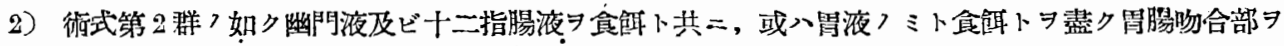

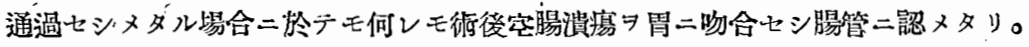

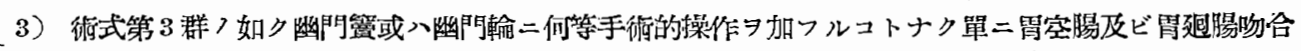
タナシ, 胃內容食餌・十二指腸卜吻合部二分流セシメタル埸合, 或入背式第 4 群ノ如ク, 小胃二空腸又八

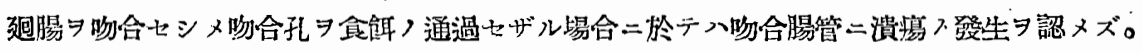

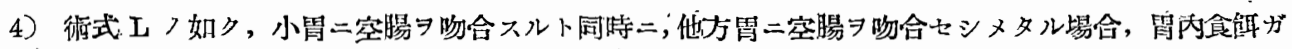
直接流大通過スル腸管二潰瘍フ發生ヨ認メタルニ拘ラズ, 食慨ノ流通セザル晹管ニソフ發生ナシ。

5）胃及ビ小胃二吻合セル腸管粘膜二認メラルル㙷著ナル變化入粘膜表層並二閒質二於ヶル白血球浸潤

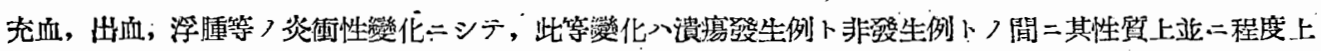
〉差違ヨ認メズ。

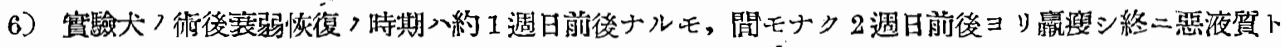

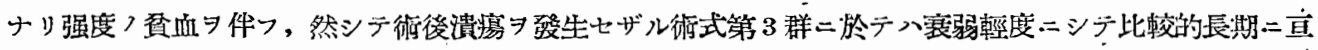
リ生存入。

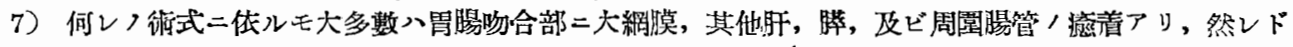

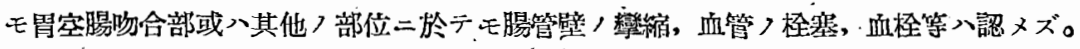

8）腫大七ル腸淋巴濾胞ヨり潰瘍へフ移行入認又難シ。

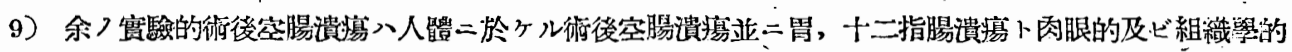


新見二酷似セルモ病機ガ著シク急激ニシテ且早期二呀孔スル點二於テ趣ヨ異ニスル處ナリ。

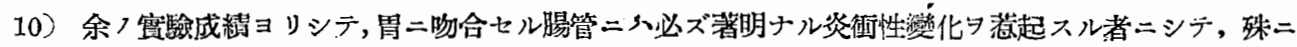

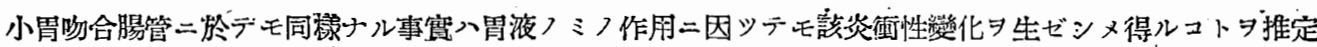

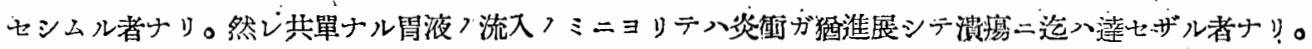

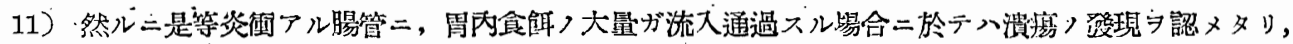

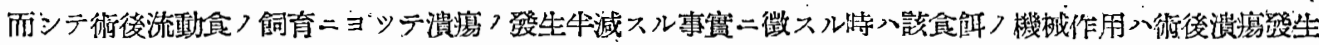
上相當〉意義有スルモ’卜認义得。

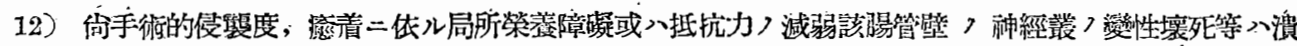

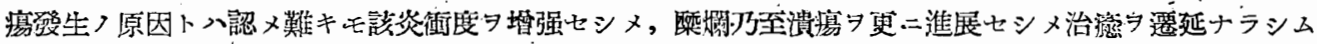
ル黙に於テ意義アルモつト考つ。

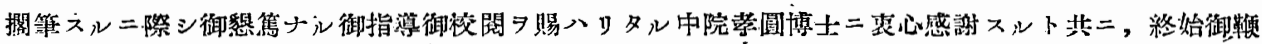

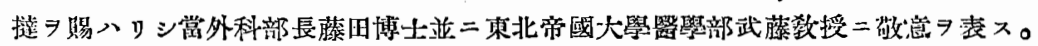

\section{參 考 文 獻}

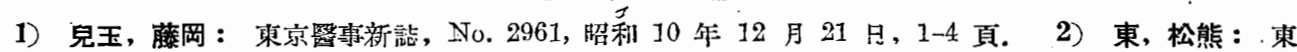
宗醫事新誌, No. 3031, 昭利 12 年. 5 月, 7-9 頁. 3) 松熊：熊本醫學雜誌, 第 13 卷, 第 8 號, 95124 頁. 4) 中田, 田中： 北越醫學雜誌，第 52 年，第 6 號，779-789 頁. 5) 林：日本消化器病

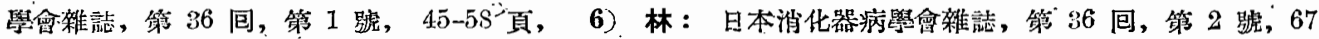

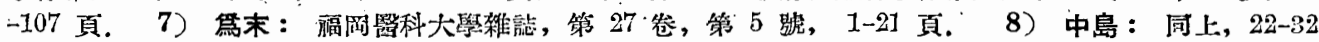
頁. 9) 友田：日本外科學會雜詰, 第 37 回, 第 12 號, 1875-1913 頁. 10）後藤, 友田：グレ

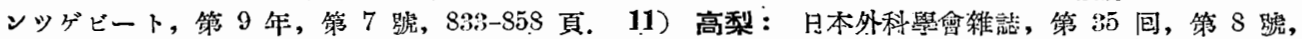
995-1041 頁. 12) 友田：治療及處方，昭利 13 年 4 月號，107-118 頁，13）小田：日本外科學

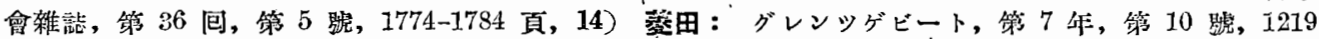

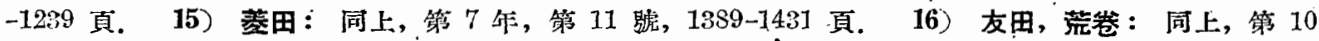
年, 第 9 號, 1233-1250 頁. 17) 同上，第 10 號，1466-1477 頁. 18）同上, ，第 11 號, 16091623 頁. 19）同上,第 12 號, 1732-1738 頁, -20). 同上, 第 11 年, 第 3 號, 368-381 頁.

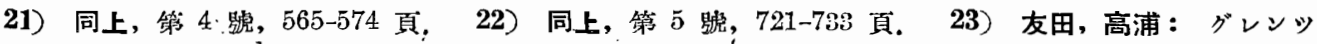

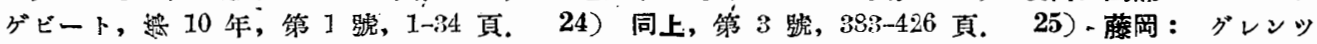
ゲビート,第 8 年, 第 8 號, 909-959 頁。 26) 秋山：グレンッグビート, 第 8 年, 第 10 號, 118

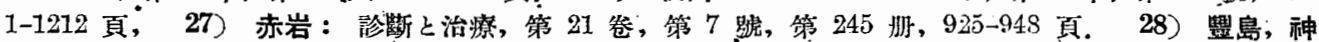

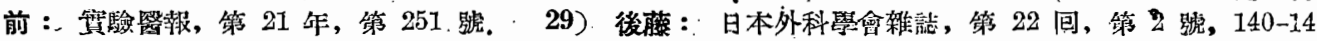

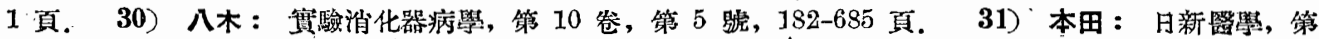
16 年, 第 10 號, 1651-1666 頁. 32) 同上, 筆 11 號, 1777-1791 頁，33）大原：日本外科學會

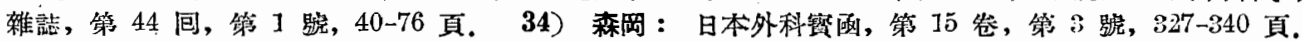
35) 同上, 第 4 號, 519-544 頁. 36) 同上, 第 5 虎, 737-758 頁. 37) 同上, 第 6 㩆, 872-886 頁. 38) Flörcken, H. u. E. Steden: Arch. klin. Chir., Bd. 148, S. 178-184 (1926). 39) Zukschwerdt, L. u. E. Becker: Dtsch. Z. Chir., Bd. 241, S. 39-54 (1933). 40) Hanke, H.: Dtsch. Z. Chia,,Bd, 249, S. 213-223 (1937). 41). Weiss, A.-G., et W. Aron; ibid., t. 112, P. 10228 (1933). 42) Weiss A.-G., et E. Aron: ibid., t. i12, P. 1530 (193i3). 43) Weiss, A.-G., et E. Aron: Comptes Rendus, de la soc de biol.; t. 112, P. 1526 (1933). 44) Guleke, N.: Zbl. Chir., Nr. 17, S. 898-904 (1938). 45) Nasarov, N. N.: Arch. Klin. Chir., Bd. 141, S. 557-565 (1926). 46) Engels, H.: Arch. kJin. Chir., Bd. 192, S. 94-133 (1938). 47) Starlinger, F.: Erg. Chir., Bd. 25, S. 380-476 (1932). 48) Bürkle, H. de la Camp : Dtsch. Z. Chir., Bd. 220, S. 31-88 (1929). 49) Schubert, A. u. T. Beer : Arch. klin. Ohir., Bd. 183 , S. 587-558 (1924). 50) Finsterer, H.: Arch. klin. Ohir.,Bd. 193, S. 581-592 (1924). 51) Nordmaun, E.: Arch. kin. Chir., Bd. 125, s.:92-120 (1928). 52) Denk,W.: Arch. klin. Chir., Bd. 116, S. 1-52 (1921). 53) Kato, H.: Arch. klin. Chir., Bd. 195, S. 193-202 (1 939). 54) Mizoguti, S.?' Zbl. Chir., Nr. 8, S. 420-427 (1939). 55) Tomoda, M.: Zbl. Chir., Irr. 29, S. 1685-1640 (1939). 56) Duschl, L.: Dtsch. Z. Chir., Bd. 2s6, s. 408-423 -(19 32). 57) Zukschwerdt, L. u. Th. Eck: Dtsch. Z. Chir., Bd. 286, S. $242-464$ (1932). 
手束論交附圆 $\{I\}$

第 - . 泪

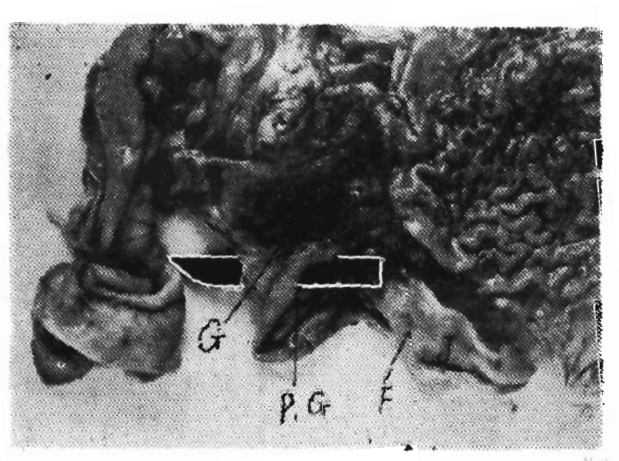

第二 浠

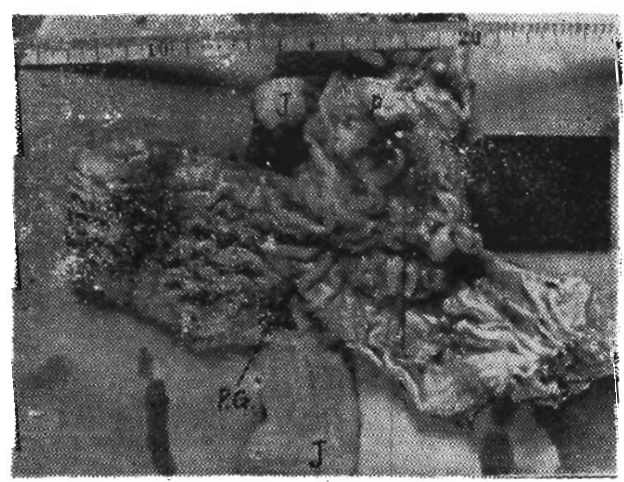

第

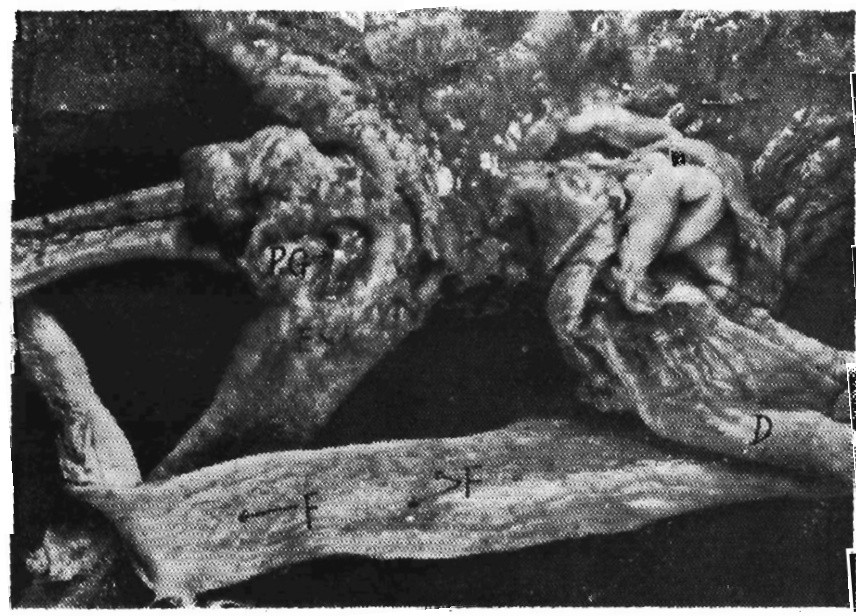

第 苔 频

\section{第四圆}

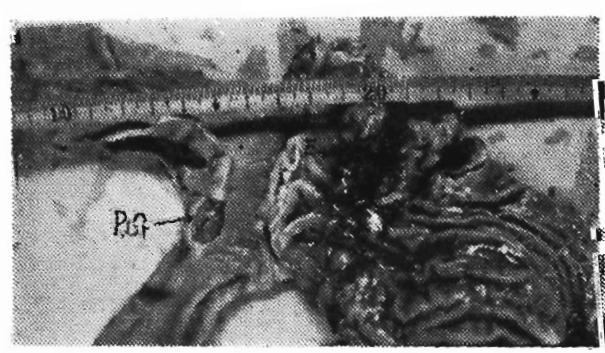

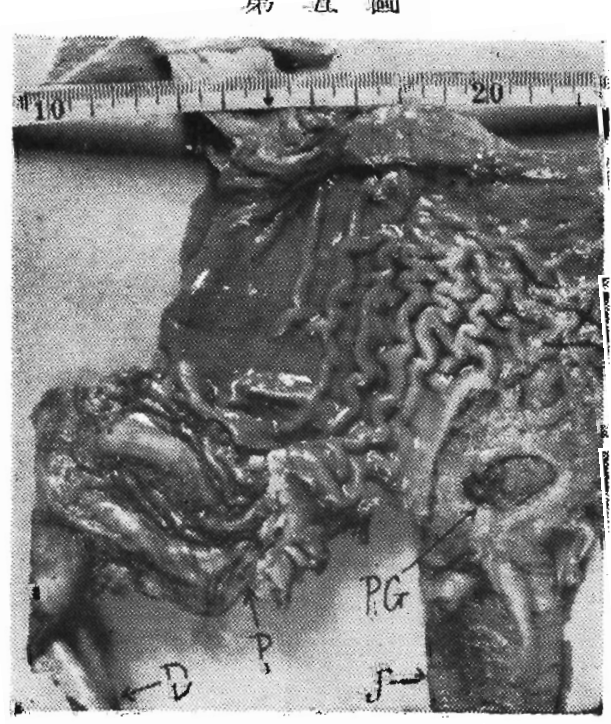


手束論文附圆 (II)

第 六 四

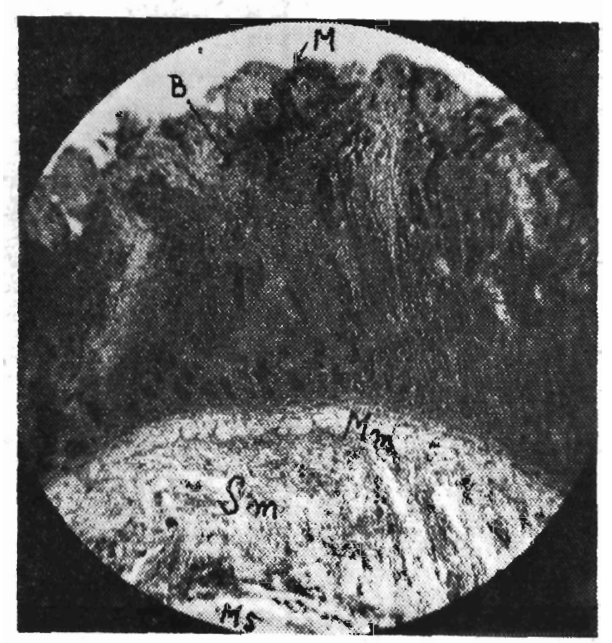

第八踾

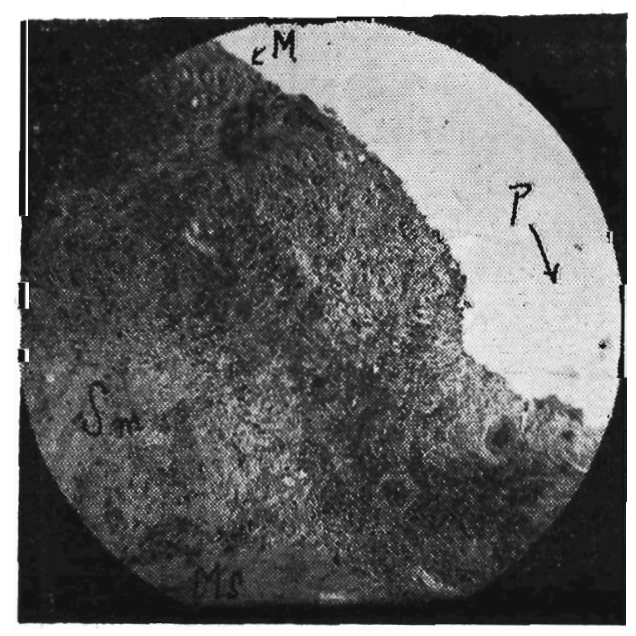

第 七 骨

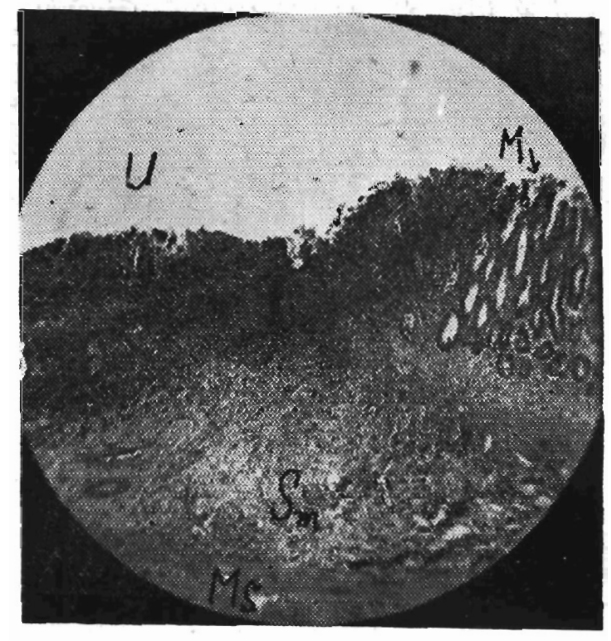

第 儿堛

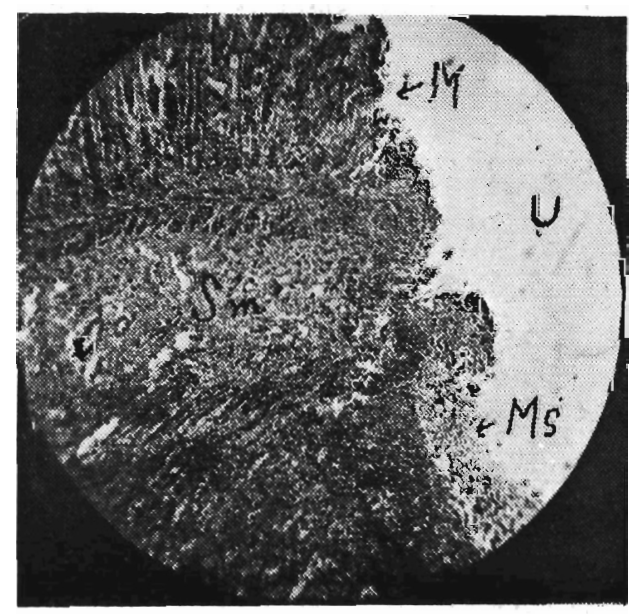

